UNIVERSIDADE DE SÃO PAULO FACULDADE DE ECONOMIA, ADMINISTRAÇÃO E CONTABILIDADE DEPARTAMENTO DE CONTABILIDADE E ATUÁRIA PROGRAMA DE PÓS-GRADUAÇÃO EM CIÊNCIAS CONTÁBEIS

RISCO IDIOSSINCRÁTICO E CONCENTRAÇÃO DE PROPRIEDADE: EVIDÊNCIAS DO MERCADO DE CAPITAIS DO BRASIL

Heloísa Pinna Bernardo Orientador: Prof. Dr. Luiz João Corrar

SÃO PAULO 2014 
Prof. Dr. Marco Antônio Zago

Reitor da Universidade de São Paulo

Prof. Dr. Adalberto Américo Fischmann

Diretor da Faculdade de Economia, Administração e Contabilidade

Prof. Dr. Gerlando Augusto Sampaio Franco de Lima

Chefe do Departamento de Contabilidade e Atuária

Prof. Dr. Andson Braga de Aguiar

Coordenador do Programa de Pós-Graduação em Controladoria e Contabilidade. 
HELOÍSA PINNA BERNARDO

\title{
RISCO IDIOSSINCRÁTICO E CONCENTRAÇÃO DE PROPRIEDADE: EVIDÊNCIAS DO MERCADO DE CAPITAIS DO BRASIL
}

Tese apresentada ao
Departamento de Contabilidade e
Atuária da Faculdade de
Economia, Administração e
Contabilidade da Universidade
de São Paulo como requisito para
obtenção do título de Doutora em
Ciências.

Orientador: Prof. Dr. Luiz João Corrar

\begin{abstract}
Versão Corrigida
(versão original disponível na Faculdade de Economia, Administração e Contabilidade)
\end{abstract}

\section{SÃO PAULO}




\section{FICHA CATALOGRÁFICA}

\section{Elaborada pela Seção de Processamento Técnico do SBD/FEA/USP}

\section{Bernardo, Heloísa Pinna}

Risco idiossincrático e concentração de propriedade: evidências do mercado de capitais do Brasil / Heloísa Pinna Bernardo. -- São Paulo, 2014.

$148 \mathrm{p}$.

Tese (Doutorado) - Universidade de São Paulo, 2014.

Orientador: Luiz João Corrar.

1. Mercado de capitais 2. Risco idiossincrático 3. Concentração acionária 4. Sincronicidade 5. Transparência corporativa I. Universidade de São Paulo. Faculdade de Economia, Administração e Contabilidade. II. Título.

CDD - 332.041 
À minha avó, Maria do Carmo, à minha mãe ao meu pai

pelo amor e pelos ensinamentos 


\section{AGRADECIMENTOS}

Ao professor Luiz João Corrar, orientador e grande incentivador. Agradeço especialmente pelo apoio nos últimos quinze anos, desde o mestrado. Sou imensamente grata pela paciência, pelo carinho, pelo exemplo, pelas sábias orientações e por acreditar em mim até em momentos em eu mesma duvidei que conseguiria.

Aos meus filhos, pelo amor que nos dedicamos, pelo significado que eles têm na minha vida e pelo tempo que deixei de estar com eles.

Aos professores Eduardo Kayo, Fávero, Securato, Wilson Nakamura pelos ensinamentos, pelas oportunidades que me proporcionaram e pelos preciosos conselhos que me deram.

Aos amigos de uma vida inteira, que estiveram ao meu lado até nas fases mais difíceis que vivi: Marilda, Richard, Suzana Krause e Vera. Aos amigos que chegaram a pouco e tem ajudado a tornar o meu caminho mais suave: Fábia, Fátima, Rosi, Suzana Wayand.

Aos colegas Bianca, Benjamim, Jorge, Robson e Valdiva pelas frutíferas discussões e reflexões.

Aos professores Nuno e Savóia pelas novas possibilidades que me mostraram. À Nina que, sem pedir anda em troca, me fez companhia nas longas horas dedicadas à essa tese. 


\section{Resumo}

Bernardo, H. P. (2014) Risco idiossincrático e concentração de propriedade: Evidências do mercado de capitais do Brasil. (Tese de doutorado, Faculdade de Economia, Administração e Contabilidade, Universidade de São Paulo, São Paulo).

Esta pesquisa investigou os efeitos da estrutura de propriedade e da clareza na comunicação entre empresa e mercado sobre o risco idiossincrático das ações negociadas no mercado brasileiro de capitais de 2002 a 2012. O risco idiossincrático $\left(1-R^{2}\right)$ foi medida a partir do coeficiente de determinação da regressão dos retornos da ação em relação aos fatores sistemáticos $\left(R^{2}\right)$ e reflete o percentual dos retornos da ação não explicados pelos fatores sistemáticos. Neste estudo, empresas com alta concentração acionária são aquelas em que o maior acionista detém mais de $50 \%$ do total das ações ou em que os três maiores acionistas detêm, em conjunto, mais de $70 \%$ do total das ações. A concentração acionária afeta positivamente a volatilidade idiossincrática, enquanto o porte da empresa e a liquidez do papel na bolsa têm efeito oposto. Foi observada relação positiva entre a concentração acionária e o risco idiossincrático que, por sua vez, é menor nas empresas do setor financeiro, com alta concentração acionária. Contudo, parte do risco idiossincrático observado nas ações das empresas com alta concentração acionária decorre da menor liquidez do papel como consequência da pequena parcela das ações disponível aos investidores, e supostamente não está relacionada à incorporação das informações específicas aos preços. Nas empresas com alta concentração acionária, a volatilidade idiossincrática está positivamente relacionada à rentabilidade reportada e negativamente associada ao endividamento. As oportunidades de crescimento estão positivamente relacionadas com o risco idiossincrático nos casos em que a concentração acionária não é alta. Esse fato é compatível com a suposição de que as divergências sobre o impacto futuro do aproveitamento econômico das oportunidades com as quais a empresa se depara, gerariam variações nos preços decorrentes de informações específicas, corroborando com a suposição de que o risco idiossincrático reflete, ao menos em parte, as informações específicas incorporadas aos preços. Por outro lado, não foram encontradas evidências de que a clareza na comunicação entre a empresa e o mercado tenha efeito significativo na variabilidade dos retornos idiossincráticos. Se as informações específicas são incorporadas aos preços, a incorporação, ao que parece, não se dá pelos mecanismos atuais de fluxo de informação entre empresa e investidores. 


\begin{abstract}
This research investigates the effects of the ownership structure and the clarity of firm activities and performance to outsiders with regard to the idiosyncratic volatility of shares traded on the Brazilian stock exchange from 2002 to 2012. The idiosyncratic volatility $\left(1-R^{2}\right)$ is based on the coefficient of determination of regression of stock returns in relation to systematic factors $\left(R^{2}\right)$, and reflects the percentage of stock returns not explained by these systematic factors. In this study, companies with high stock concentration are those whose largest shareholder holds more than $50 \%$ of the total outstanding shares or whose three largest shareholders together hold more than $70 \%$ of the total outstanding shares. Ownership concentration positively affects the idiosyncratic volatility, while the firm's size and stock liquidity on the stock exchange have an opposite effect. A positive relationship between the ownership concentration and the idiosyncratic volatility is noted, which in turn is lower in financial institutions with high ownership concentration. However, part of the idiosyncratic volatility noted in stocks of firms with high ownership concentration results from lower liquidity of its papers as a consequence of the small number of shares available to investors and supposedly not related to firm-specific information incorporated into stock prices. In firms with high ownership concentration, idiosyncratic volatility is positively related to reported profitability and negatively associated with leverage. Growth opportunities are positively related to idiosyncratic volatility in cases where ownership concentration is not high. This fact is consistent with the assumption that variances of the future impact of the economic use of opportunities faced by a firm would generate variations in in its stock price as a result of specific information, supporting the assumption that the idiosyncratic volatility reflects, at least in part, firm-specific information incorporated into stock prices. On the other hand, no evidence is found that the clarity of firm activities and performance to outsiders has a significant effect on the variability of idiosyncratic returns. If firmspecific information is incorporated into its stock price, the incorporation, it seems, does not occur by current mechanisms of information flow between the firm and investors.
\end{abstract}




\section{LISTA DE FIGURAS}

Figura 1: Linha do tempo para um estudo de evento.

81

Figura 2: Distribuição de frequência das participações do maior acionista e dos três maiores acionistas das empresas analisadas nos anos de 2002 a 2012.. 95 Figura 3: Gráfico do intervalo de confiança Intervalo de Confiança para média IDIO_1 e IDIO2, agrupado pela participação do maior acionista. 103

Figura 4 :Gráfico do intervalo de confiança para média IDIO_1 e IDIO2, agrupado pela participação dos três maiores acionistas.... 104

Figura 5: gráfico do intervalo de confiança do valor de mercado médio das empresas por grupos de participação acionária. 110

Figura 6: Gráfico do intervalo de confiança da média da liquidez em bolsa, para nível de confiança de $95 \%$, 112

Figura 7: Gráfico do intervalo de confiança da média de IDIO_1 e IDIO_2 em subamostras organizadas por liquidez em bolsa e concentração acionária dos três acionistas. 113

Figura 8: Intervalo de confiança para a média de IDIO_1 por quartil de OPAC e de PEAD_2.

\section{LISTA DE QUADROS}

Quadro 1: Quadro resumo das principais evidências sobre a relação entre risco idiossincrático/sincronicidade e o ambiente informacional 64

\section{LISTA DE TABELAS}

Tabela 1: Número de observações por ano das empresas selecionadas 72

Tabela 2: Número de observações por ano das empresas em que o R2 foi

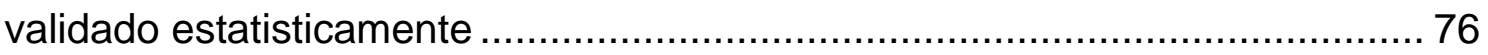

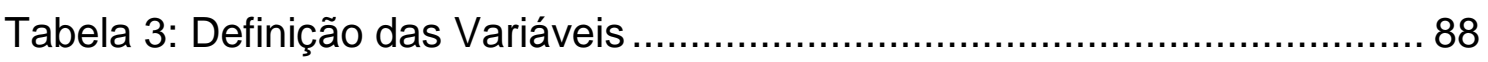

Tabela 4: Estatística descritiva das variáveis em estudo ................................ 91

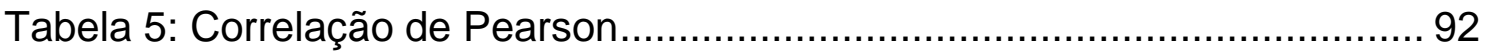

Tabela 6: Estatística descritiva de informações sobre concentração acionária 94 Tabela 7: Percentual dos direitos de propriedade detidos pelo maior acionista que detém pelo menos $5 \%$ do capital total. 
Tabela 8: Percentual dos direitos de propriedade detidos pelos três maiores acionistas que, individualmente detém pelo menos $5 \%$ do capital total. .......... 96 Tabela 9: Efeito da concentração de propriedade (maior acionista) e da transparência corporativa sobre o risco idiossincrático................................... 98

Tabela 10: Efeito da concentração de propriedade (maior acionista) e da transparência corporativa sobre o risco idiossincrático.................................. 100 Tabela 11: Testes estatísticos univariados para valores diferenças dos escores de risco idiossincrático 102 Tabela 12: Efeito da concentração de propriedade (maior acionista) sobre o risco idiossincrático.

Tabela 13: Efeito da concentração de propriedade (três maiores acionistas)

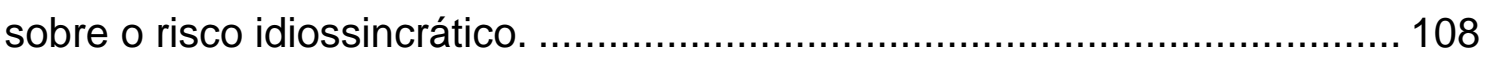

Tabela 14: Estatística descritiva da participação acionária ............................ 109 Tabela 15: Estatística descritiva do valor de mercado das empresas por quartil de participação acionária 110

Tabela 16: Critério para o agrupamento das subamostras organizadas por liquidez em bolsa e participação dos três maiores acionistas

Tabela 17: Testes estatísticos univariados para diferenças dos escores de risco idiossincrático

Tabela 18: Efeito da opacidade corporativa sobre o risco idiossincrático, ..... 116 Tabela 20: Estatística descritiva das submostras organizadas por quatis de

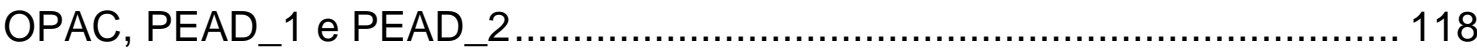
Tabela 21: Amostras das empresas observadas por ano - 2002 a 2012 ....... 143 Tabela 22: Intervalo de confiança da liquidez em bolsa por quartil de participação acionária 


\section{SUMÁRIO}

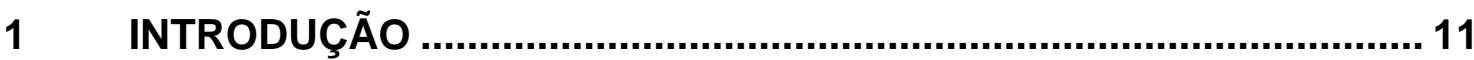

1.1 Contextualização e definição do problema ......................................... 14

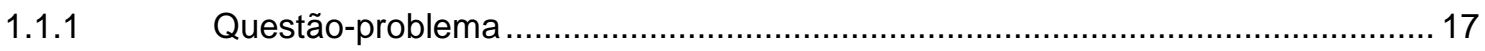

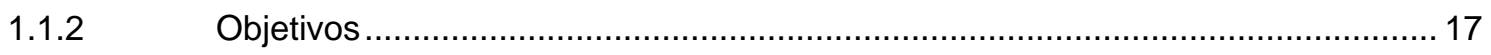

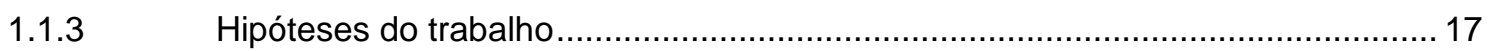

1.2 Tese

2 REFERENCIAL TEÓRICO

2.1 O comportamento dos preços das ações ......................................... 21

2.2 Eficiência de mercado e o modelo martingale ..................................... 21

2.3 Eficiência de mercado e equilíbrio de mercado ................................... 23

2.4 Eficiência de mercado e finanças comportamentais............................... 25

2.5 Modelos de precificação de ativos e os fatores de risco........................ 27

2.6 Risco Idiossincrático, sincronicidade e comovimento ............................. 32

2.7 Relação entre risco idiossincrático e sincronicidade ( $\boldsymbol{\psi} j \boldsymbol{t}$ ) ................... 39

2.8 Risco idiossincrático, sincronicidade e alocação de capital na economia 43

2.9 Risco idiossincrático, sincronicidade e fluxo de informações ................ 47

2.10 Concentração acionária, risco idiossincrático e sincronicidade .............50 50

2.11 Opacidade e transparência corporativa ............................................ 54

2.12 Accruals discricionários, transparência e opacidade …………............. 56

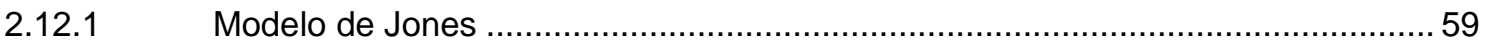

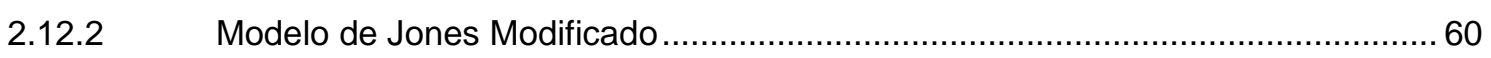

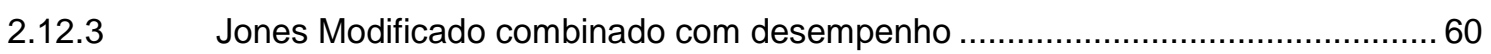

2.13 Opacidade e o post earning announcement drift................................ 61

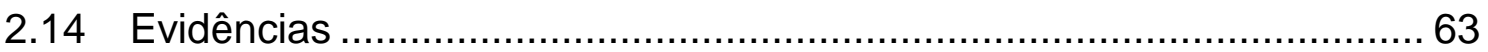

$3 \quad$ ABORDAGEM METODOLÓGICA .................................................... 71

3.1 População e amostra.................................................................... 71

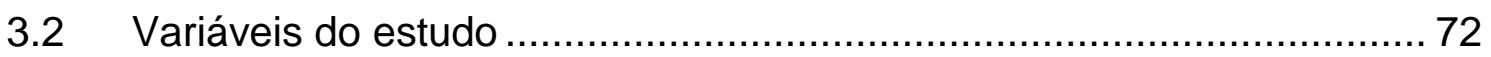

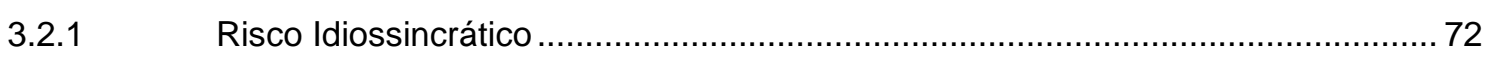

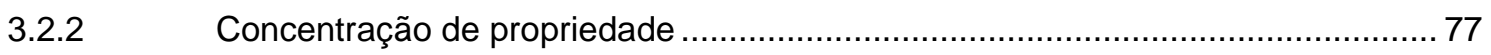

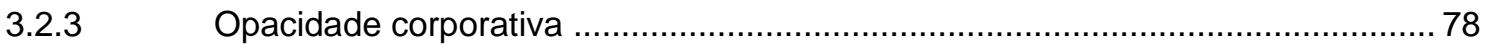

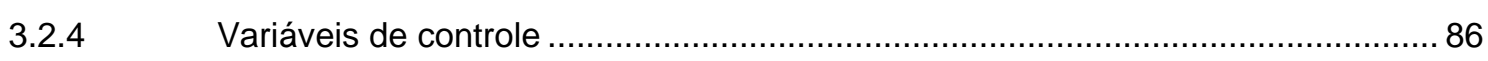

4 ANÁLISE DOS RESULTADOS ....................................................... 91 
4.1 Estatística descritiva

4.2 Análise multivariada da relação entre o risco idiossincrático e concentração de propriedade e análise da interação entre concentração de propriedade e transparência corporativa 96

4.3 Concentração de propriedade e risco idiossincrático ............................ 101

4.4 Liquidez, concentração acionária e risco idiossincrático ..................... 111

4.5 Impacto da opacidade sobre o risco idiossincrático: modelo e resultados 115

5 CONCLUSÕES E CONSIDERAÇÕES FINAIS 119

REFERÊNCIAS 125

APÊNDICE 1: Amostras das empresas observadas por ano - 2002 a 2012

APÊNDICE 2: Intervalo de confiança da liquidez em bolsa por quartil de participação acionária 148 


\section{INTRODUÇÃO}

No centro da Moderna teoria financeira está a relação entre risco e retorno, que ganhou especial notoriedade com o trabalho de Markowitz (1952) sobre seleção de carteiras. Pela primeira vez os conceitos de risco e retorno haviam sido apresentados com base em formulações matemáticas apoiadas nas métricas de média e variância de retornos dos ativos.

Ainda que intuitivamente já se tivesse a percepção de que os investidores deveriam exigir maiores retornos por ativos mais arriscados, como forma de compensação do risco assumido, foi a partir dos trabalhos Markowitz (1952), Sharpe (1964), Lintner (1956) e Mossin (1966) que os economistas foram capazes de mensurar a compensação esperada pelo risco assumido. O Modelo de Precificação de Ativos Capital Asset Pricing Model (CAPM) desenvolvido por Sharpe (1964), Lintner (1956) e Mossin (1966) pressupõe que, em um mercado em equilíbrio, o retorno esperado de um ativo deve ser igual ao retorno do ativo livre de risco acrescido de um prêmio pelo risco a que o investidor está submetido.

Em geral, risco na literatura financeira está associado à distribuição dos retornos, medido como variância, desvio padrão ou coeficiente de variação dos retornos de um ativo. Por outro lado, risco total de um ativo pode ser subdividido em risco sistemático (ou conjuntural) e risco não-sistemático, também chamado de risco próprio do ativo ou ainda "risco idiossincrático".

O risco sistemático refere-se ao conjunto dos riscos impostos pelo sistema econômico, político e social. Em uma crise econômica o sistema afetará todos os ativos, embora o grau de influência possa ser diferente entre eles. Segundo a teoria financeira, para combinações eficientes de ativos e no equilíbrio deve haver uma relação linear entre retornos esperados e o desvio padrão dos retornos para uma combinação eficiente de ativos de risco. Entretanto, para expressar a relação entre risco e retorno de ativos individuais é importante considerar o risco sistemático, aquele não diversificável (Sharpe, 1964, p. 436). De acordo com o CAPM, os investidores devem ser compensados pelo risco sistemático assumido, o qual corresponde ao componente do risco total que é explicado pelo retorno do mercado. Esse risco é capturado pela regressão dos excessos de retorno do ativo em relação ao excesso de retorno do 
mercado e a estimativa do risco sistemático é 1medida pelo coeficiente angular da regressão: beta.

Já o risco idiossincrático (risco não-sistemático, específico ou ainda risco próprio), decorre do comportamento da parcela dos retornos do ativo que não está correlacionada com os movimentos do mercado. Pode ser eliminado pela diversificação de tal forma que um investidor, em detendo uma carteira de ativos diversificada, não estará submetido ao risco específico de cada ativo. Para Sharpe (1964) o risco idiossincrático não seria um tipo de risco para o qual os investidores exigiriam remuneração, pois pode ser eliminado pela diversificação. Porém, é um dos tipos de riscos a que estão sujeitos os arbitradores ${ }^{1}$ que detêm carteiras nãodiversificadas. Ambos os riscos, sistemático e não-sistemático, são importantes para os arbitradores especializados, mas o risco idiossincrático é provavelmente mais relevante dado que não pode ser protegido (hedged) (Shleifer \& Vishny, 1997).

Pela teoria de finanças o valor de qualquer ativo, inclusive de uma firma, equivale ao valor presente dos fluxos de caixa futuros. Dessa forma, o preço das ações deve refletir o valor presente dos benefícios esperados ou, dito de outra maneira, espelha as expectativas dos investidores em relação aos lucros futuros, descontados a uma taxa que corresponda ao risco associado à atividade.

Então os preços das ações devem subir ou descer em resposta às informações que afetam o lucro futuro de cada empresa e às mudanças na taxa de desconto, a qual é influenciada pelas variáveis macroeconômicas. A implicação disso é que os preços das ações de diferentes empresas só deveriam se mover em conjunto se os lucros também se movessem da mesma forma, ou então como consequência das mudanças nas variáveis macroeconômicas que afetariam de maneira análoga todas as empresas (Pindyck \& Rotemberg, 1993, p. 1073).

No entanto, a observação empírica indica que a correlação entre os lucros não é suficiente para explicar o comportamento da sincronia dos retornos das ações (Pindyck \& Rotemberg, 1993; Roll, 1988). Roll (1988) instigado para compreender a

\footnotetext{
${ }^{1}$ Segundo Shleifer e Vishny (1990, p. 148) arbitradores são investidores racionais que negociam com base no conhecimento de que o preço de um dado ativo é diferente de seu valor fundamental. Arbitragem, segundo (Pontiff, 2006, p. 36) é a transação na qual o agente racional tenta obter lucro do erro de precificação : "is the transaction where a rational agent tries to profit from mispricing."
} 
complexidade dos fatores que afetam os retornos das ações em sua totalidade, concentrou-se no estudo da parcela dos retornos das ações não explicada pelos modelos de precificação de ativos. Naquela pesquisa Roll (1988) concluiu a parte dos retornos das ações não explicada pelos fatores sistemáticos dependeria do volume de informações incorporadas aos preços ou de "frenesi ocasional sem relação com informações concretas"2(Roll, 1988, p. 566), referindo-se ao que Black (1986) denominou ruído (noise).

As informações específicas são incorporadas aos preços por meio de algum mecanismo relacionado ao ambiente informacional da empresa ${ }^{3}$. O conflito de interesses entre aqueles que detém os direitos de propriedade pode afetar o ambiente informacional da empresa, que inclui os custos de transação, a liquidez das ações da empresa e a atenção que recebe pelos participantes do mercado. A prevalência da assimetria de informações entre grandes acionistas e acionistas pulverizados é uma característica das empresas em que grupos de acionistas detêm grande participação sobre os direitos de propriedade.

Entretanto, na ausência de custos para se obter as informações ou quando os "negociadores informados (informed traders) conseguem informações precisas, então [...] o preço do mercado revelará a maior parte das informações dos operadores informados"4 (S. J. Grossman \& Stiglitz, 1980, p. 404). Nesse sentido, os grandes acionistas que detém um bloco de ações (blockholders) ${ }^{5}$ podem monitorar a atuação da gestão e ter acesso a informações mais precisas e com menor custo de obtenção. Dessa forma, deve existir uma relação entre as informações específicas incorporadas aos preços e a atuação dos blockholders na gestão, seja como gestores ou monitorando a atuação daqueles.

Se de um lado, os informed traders incorporam as informações nos preços, a clareza com que as atividades e o desempenho da empresa são comunicados a terceiros,

\footnotetext{
2 "[...] occasional frenzy unrelated to concrete information." (Roll, 1988, p. 566)

3Para um aprofundamento entendimento do que a literatura compreende por ambiente informacional, ver Kelly (2005), seção II.

4 "[...] when informed traders get very precise information, then [equilibrium exists and] the market price will reveal most of the informed traders' information"

${ }^{5}$ No Brasil, os acionistas que atingirem participação que corresponda a 5\% (cinco por cento) devem ser identificados. Na literatura internacional o termo Blockholder tem sido usado para designar os acionistas que detém porcentagem ou superior a $5 \%$ das ações da empresa.
} 
qual seja, a transparência corporativa (R. M. Bushman, Piotroski, \& Smith, 2004; R. M. Bushman \& Smith, 2003), afeta a disseminação de informações aos investidores.

A clareza na comunicação das empresas para com os investidores tem sido cobrada pelos os órgãos reguladores de mercados. A título de exemplificação, a Instrução 480/09 da Comissão de Valores Mobiliários (CVM) ampliou a exigência do detalhamento das informações ao mercado. Tornou obrigatória a divulgação de informações como remuneração de administradores, transações com partes relacionadas e o detalhamento e mensuração da exposição a riscos. Também deliberou sobre a faculdade dos gestores das empresas divulgarem projeções e estimativas de resultados. Tais medidas são compatíveis com a busca pela eficiência informacional, definida por Bushman e Smith (2003, p. 81) como a precisão com que as informações estão refletidas nos preços das ações.

A relevância da transparência para os mercados de capitais também está assinalada no relatório divulgado pela Securities and Exchange Commission - SEC dos Estados Unidos. Naquele documento é ressaltada a importância de um sistema interativo de fluxo de informações de modo a aprimorar a transparência e acessibilidade, mantendo o mercado estadunidense competitivo (U.S. Securities and Exchange Commission, 2009).

As empresas menos transparentes na divulgação de informações ao mercado são menos atrativas aos investidores informados (Bloomfield, Hara, \& O'Hara, 1999). Com menos informações específicas sobre a empresa, é provável que os investidores reavaliem o valor da empresa com base nas oscilações do mercado e/ou do setor, justificando a tendência dos retornos das ações se moverem em sincronia com os fatores sistemáticos e diminuindo a volatilidade dos retornos idiossincráticos. Nesse contexto, quando da divulgação das informações obrigatórias auditadas, os investidores podem ajustar suas expectativas incorporando a nova informação no preço.

\subsection{Contextualização e definição do problema}

Embora seja reconhecida a importância do fluxo de informações para os mercados de capitais, as pesquisas que analisam o impacto do ambiente informacional na 
tendência dos preços se moverem em sincronia com os retornos do mercado não são conclusivas e por vezes apresentam resultados contraditórios.

De um lado pesquisadores como Rajgopal e Venkatachalam (2011), Durnev et al. (2003) encontraram evidências de que a qualidade na comunicação entre empresas e investidores geram assincronicidade ${ }^{6}$ e, consequentemente aumentam o risco idiossincrático. Outros estudos apontam resultados na direção oposta, sugerindo que a qualidade das informações diminui o risco idiossincrático, aumentando assim a tendência dos preços se moverem de maneira sincronizada com o mercado: Dasgupta et al.(2010) e Chen, Huang e Jha (2012),

Existe, portanto, uma lacuna na literatura financeira envolvendo estudos sobre o comportamento do retorno idiossincrático que se relaciona à tendência dos preços se moverem em conjunto em relação ao mercado. Muitas das pesquisas analisam o comportamento dos retornos idiossincráticos de maneira agregada, comparando a sincronicidade média dos retornos das ações em cada economia, incluindo as economias emergentes.

$\mathrm{Na}$ literatura científica, dos trabalhos que abordam o risco idiossincrático ou a sincronicidade de maneira não-agregada, vários tratam do mercado estadunidense (Dasgupta et al., 2010; Ferreira \& Laux, 2007; Hou, Xiong, \& Peng, 2006; Jiang, Xu, \& Yao, 2009). Alguns abordaram o mercado de capitais chinês (Dasgupta et al., 2010; Ferreira \& Laux, 2007; Hou et al., 2006; Jiang et al., 2009). Outros focaram o mercado de capitais chinês (F. a. Gul, Cheng, \& Leung, 2011; F. a. Gul, Kim, \& Qiu, 2010). Poucos, como Chan e Hameed (2006), analisaram relação entre a sincronicidade e a atuação dos analistas de investimentos usando amostras de várias economias emergentes.

No Brasil, o estudo de Martin, Cia e Kayo (2010) testou a validade empírica de determinantes do risco idiossincrático com base em indicadores contábil-financeiros, mas não relacionou o ambiente informacional da empresa tampouco foi tratada a influência da estrutura de propriedade sobre o comportamento do retorno idiossincrático.

\footnotetext{
${ }^{6}$ Tradução livre para o termo: asynchronicity
} 
Diferentemente do que ocorre no ambiente estadunidense onde são conduzidas grande parte das pesquisas sobre risco idiossincrático, no mercado de capitais brasileiro predominam as empresas em que poucos acionistas detêm parcela importante do total das ações, fato que modifica a natureza dos efeitos decorrentes dos conflitos de agência (Silveira, Lanzana, Barros, \& Famá, 2004) e interfere no ambiente informacional.

A presença de grandes acionistas nas empresas pode de um lado ter um efeito positivo pelo monitoramento da gestão, pelo interesse na maximização do valor da empresa e por terem certa facilidade na coleta de maior quantidade de informações a um custo reduzido de obtenção. $O$ efeito negativo surge do fato de que os grandes acionistas podem ter interesse em obter vantagens privadas às custas dos demais investidores (Silveira et al., 2004).

O efeito positivo, ora descrito, estaria relacionado a um maior risco idiossincrático na medida em que o grande acionista tem incentivos para direcionar o preço da ação ao valor fundamental, incorporando as informações específicas nos preços. Já o efeito negativo da concentração de propriedade está relacionado com a redução do risco idiossincrático o qual seria absorvido pelo grande acionista que não tem incentivos para proporcionari a incorporação das informações específicas nos preços. Cabe, portanto, investigar para o caso brasileiro o efeito da concentração acionária e da comunicação entre empresa e mercado sobre o risco idiossincrático.

Por outro lado, a clareza com que as atividades e o desempenho da empresa são comunicados a terceiros (ou seja, a transparência corporativa) deveria ser um fator facilitador da incorporação de maior quantidade de informação específica aos preços. Novas informações refletidas nos preços aumentam o risco idiossincrático e consequentemente reduzem a tendência dos retornos das ações se moverem em sincronia com os fatores sistemáticos (sincronicidade). A transparência só não propiciará a incorporação de informações específicas se as informações divulgadas não forem percebidas pelos participantes do mercado ou estes não utilizarem as informações divulgadas para as decisões de compra e venda da ação.

Nesse contexto, a questão-problema se apresenta da seguinte maneira: 


\subsubsection{Questão-problema}

Como a estrutura de propriedade e a clareza com que as atividades e o desempenho da empresa são comunicados a terceiros impactam o risco idiossincrático?

Para respondê-la, os seguintes objetivos são estabelecidos:

\subsubsection{Objetivos}

Considerando que a literatura aponta duas possibilidades para o impacto da estrutura de propriedade sobre o comportamento dos retornos das ações, especialmente no tocante à parcela que se refere aos aspectos específicos da empresa, o principal objetivo é:

- Investigar o papel da concentração acionária sobre o risco idiossincrático.

Contudo, se as variações de preços das ações decorrem da incorporação de informações que refletem os fatores sistemáticos e os específicos nos preços das ações, cabe investigar de que maneira o ambiente informacional afeta 0 risco idiossincrático. Então o segundo objetivo da pesquisa é:

- Analisar o impacto da transparência corporativa sobre o risco idiossincrático e sobre a tendência dos retornos das ações acompanharem os retornos do mercado (sincroniciddade)

\subsubsection{Hipóteses do trabalho}

Considerando que os grandes acionistas têm incentivos para monitorar as ações dos gestores, quando da divulgação de um resultado desfavorável o qual reflete igual expectativa no futuro, esse acionista vê vantagem em negociar parte de suas ações para investir em outro empreendimento ou atividade com maior benefício futuro esperado. Dessa maneira os preços são pressionados para baixo, incorporando no preço da ação a informação específica sobre a expectativa desfavorável.

Já, se o resultado ruim divulgado decorrer de um investimento cujo benefício esperado está no futuro, o acionista tem incentivos para não vender ações da empresa ou até mesmo adquirir no mercado secundário se ele entender que os preços estão subavaliados. Nesse contexto a decisão de adquirir mais ações da empresa no 
mercado influenciará o preço da ação para cima com base na incorporação específica sobre a expectativa de um resultado futuro, afetando o risco idiossincrático.

Além disso, o acionista que monitora a gestão da empresa pode exercer influência para que papéis da empresa sejam adquiridos pela própria empresa e mantidas em tesouraria se entender que o preço da ação está subavaliado, exercendo pressão para que os pressos subam e, nos casos mencionados, a movimentação se dará com base nos fundamentos.

Nesse contexto, formula-se a seguinte hipótese:

HIPÓTESE 1: O risco idiossincrático aumenta à medida em que aumenta o percentual da participação dos grandes acionistas, ceteris paribus.

Por outro lado, admitindo que o retorno idiossincrático decorre das variações de preços da ação motivadas por negociações de investidores com base nos fatores específicos da empresa, a clareza na comunicação entre empresa e mercado deve facilitar a incorporação de informações específicas, aumentando o risco idiossincrático. Supõe-se que as informações sobre o desempenho divulgadas de maneira clara pelas empresas ao mercado têm baixo custo de obtenção pelos investidores. Dessa forma fica facilitada a incorporação de informações específicas nos preços das ações aumentando, por consequência, o risco idiossincrático. Complementarmente, a falta de clareza na comunicação entre empresa e mercado dificulta a incorporação das informações específicas nos preços das ações. Na falta de informações específicas os investidores ajustam os preços com base na tendência do mercado, reduzindo o risco idiossincrático e aumentando a sincronicidade dos preços das ações.

Nessas condições é formulada a seguinte hipótese:

HIPÓTESE 2: A falta de transparência na comunicação entre empresa e mercado afeta negativamente o risco idiossincrático (complementarmente, afeta positivamente a sincronicidade). 


\subsection{Tese}

Nessa pesquisa argumenta-se que a incorporação das informações específicas aos preços das ações depende da clareza com que as informações sobre atividade da empresa são comunicadas ao mercado e por meio da atuação dos grandes acionistas que tem incentivos para conduzir o preço da ação em direção ao valor fundamental

Dessa forma, a tese que se defende é:

A concentração de propriedade promove incentivos aos grandes acionistas para negociar as ações da empresa com base nos fundamentos, aumentando o risco idiossincrático ao mesmo tempo em que a clareza na comunicação entre empresa e mercado, de maneira independente, permite que 0 investidor precifique tempestivamente os eventos que afetam a expectativa de desempenho futuro, aumentando a volatilidade dos retornos específicos. 


\section{REFERENCIAL TEÓRICO}

\subsection{O comportamento dos preços das ações}

O interesse dos pesquisadores pelo comportamento dos preços dos ativos não é recente. Francis (1991, p. 542) comenta que em 1841 foi publicado o livro "Ilusões populares extraordinárias e a loucura das massas"7(Mackay, 2001) em que é descrita a mania das tulipas e outros tantos relatos sobre "bolhas" de mercado. Em 1900 Louis Bachelier propôs uma teoria da especulação como tese de doutorado onde reuniu inúmeras ideias relacionadas a finanças e probabilidade, incluindo a utilização da teoria do movimento Browniano para modelar movimentos de preços no mercado financeiro (Courtault et al., 2000, p. 341).

No final dos anos 1950, Working (1958) "articulou a noção de que os preços das ações flutuam em torno do seu valor intrínseco"8 mas, até que as massas de dados pudessem ser analisadas com a utilização de computadores, as várias teorias não passavam de meras conjecturas (J. C. Francis, 1991, p. 543).

Nos anos 1960, Fama(1965b) estudou o movimento dos preços das ações integrantes do índice Dow-Jones ao longo de cinco anos, resultando na tese de doutorado publicada na íntegra no Journal of Business em 1965. Naquele estudo Fama (1965) incluiu a revisão da literatura sobre o comportamento dos preços das ações e analisou a distribuição dos retornos. Concluiu em favor de evidências da hipótese de que os preços das ações seguem o modelo random walk em que "as variações em uma série de retornos de ações não tem memória - a história passada das séries não pode ser usada para predizer o futuro de forma significativa" (Fama, 1965a, p. 6).

\subsection{Eficiência de mercado e o modelo martingale}

Com uma melhor compreensão dos processos de formação de preços proporcionados por vários estudos, entre os quais aqueles conduzidos por Working (1958), o modelo de random walk passou a ser visto como um comportamento compatível com a hipótese de eficiência de mercado. No entanto, foi a partir do estudo de Samuelson

\footnotetext{
7 Título em português do livro: "Extraordinary popular delusions and the madness of crowds" 8 "articulated the notion that security prices flutuate around their intrinsic value"(J. C. Francis, 1991, p. 543)
} 
(1965) que o modelo do random walk foi incluído em uma estrutura de equilíbrio econômico.

A hipótese de que os preços das ações seguem o modelo de random walk apresentava algumas contradições à ideia de precificação racional dos ativos pois não estariam, os preços das ações, sujeitos às leis de oferta e demanda que rege o comportamento de outros ativos. Se os preços não seguem qualquer padrão, então qual seria o papel da análise fundamentalista? Em um mercado em que os indivíduos são racionais, como idealizado pelos economistas, seria esperado o imediato ajuste dos preços às novas informações enquanto o lento ajustamento dos preços implicaria na existência de possibilidade de negociações com lucro (LeRoy, 1976).

Porém, um modelo menos restritivo sobre o comportamento dos preços das ações que incluísse os argumentos do modelo de random walk parecia mais razoável. Nesse sentido, Samuelson (1965) estabeleceu a relação entre eficiência de mercado e martingale (LeRoy, 1989).

Os processos do tipo martingale são modelos que pretendem caracterizar o equilíbrio dos mercados financeiros, admitindo que as taxas de retorno são um "jogo justo" (fair game). Um processo estocástico é um martingale se a melhor previsão para o período $\mathrm{t}+1$ de um determinado processo é aquela que poderia ser construída com base na informação corrente. Analogamente, diz-se que se um dado processo é um "jogo justo" (fair game), a previsão para o período $\mathrm{t}+1 \mathrm{com}$ base na informação relativa ao período t é zero. A partir do enfoque microeconômico de Samuelson (1965), Fama (1970) estruturou uma revisão da literatura que tornou popular a expressão "Mercado de Capitais Eficiente" relacionada ao modelo martingale (LeRoy, 1989, pp. 15891592). Fama (1970) definiu um mercado eficiente como sendo aquele em que os preços "refletem completamente" todas as informações disponíveis e atribuiu a Roberts (1959) a distinção entre as três versões de eficiência, quais sejam: fraca, forte e semiforte.

Em geral, análises empíricas para avaliar a eficiência de mercado, como aqueles conduzidos por Fama (1970), testam o modelo martingale no mercado de capitais. No entanto, a teoria dos mercados eficientes tem como pilar a noção de que os preços dos ativos são determinados pelas interações de interesses pessoais de agentes 
racionais. A transição entre a ideia intuitiva de mercado eficiente e o modelo martingale não é direta. Alguns economistas financeiros identificam a eficiência de mercado com um modelo particular de equilíbrio no mercado financeiro (LeRoy, 1989, p. 1613).

\subsection{Eficiência de mercado e equilíbrio de mercado}

"[...] a teoria dos mercados eficientes é apenas a teoria do equilíbrio competitivo aplicada ao mercado de ativos. Uma importante ideia na teoria do equilíbrio competitivo é o princípio Ricardiano da vantagem comparativa: A Inglaterra exportava tecido para Portugal e importava vinho de Portugal não porque a Inglaterra necessariamente tinha uma vantagem absoluta sobre Portugal na produção de tecido, mas porque a Inglaterra produzia tecido comparativamente mais barato do que vinho relativamente a Portugal. A mesma ideia se aplica analisando o equilíbrio nos mercados financeiros, exceto que a vantagem comparativa é conferida pelas diferenças nas informações detidas pelos investidores, ao invés das diferenças em produtividade entre produtores"9(LeRoy, 1989, p. 1583)

Num contexto em que equilíbrio competitivo é definido como a situação em que os preços são tais que não há possibilidade de lucros por arbitragem, a suposição de que os mercados estão sempre em equilíbrio não é compatível com um mercado em que a arbitragem não está isenta de custo ou de riscos. Com base nessa observação, Grossman e Stigliz (1980) demonstraram que os custos não estão completamente refletidos nos preços, propondo um modelo de equilíbrio com algum grau de desequilíbrio.

Grossman e Stigliz (1980, p. 405) argumentam que justamente por que a informação não está isenta de custo para ser obtida, os preços não podem refletir perfeitamente as informações disponíveis, sob pena daqueles que a obtiveram dispendendo recursos não terem qualquer compensação.

De acordo com Tobin (1987), eficiência pode assumir diversos significados em finanças e ele faz uma distinção entre as formas de eficiência: a eficiência de arbitragem em informação, eficiência na valoração dos fundamentos e eficiência funcional. A eficiência de arbitragem em informação ${ }^{10}$ relaciona-se à situação na qual apenas os insiders podem ter ganhos extraordinários de maneira consistente. Isso

\footnotetext{
9 "[...] the theory of eficiente capital markets is just the theory of competitive equilibrium applied to asset markets. Na importante idea in the theory of competitive equilibrium is the Ricardian principle of comparative advantage: England exported cloth to Portugal and imported wine from Portugal not because England necesseraly had na absolute advantage over Portugal in producing cloth, but because England produced cloth comparatively more cheaply than wine relative to Portugal. The same idea applies in analyzing equilibrium in financial markets, except tha comparative advantage in conferred by diferences held by investors, rather than diferences in productivity among producers."

10 "Information arbitrage efficiency"(Tobin, 1987, p. 283)
} 
ocorre quando todas as informações disponíveis estão incorporadas aos preços. Contudo, se as avaliações daquele mercado refletem com precisão os pagamentos futuros a que os ativos dão direito, então se trata da eficiência na valoração dos fundamentos ${ }^{11}$. A eficiência funcional refere-se aos serviços que a indústria financeira desempenha na economia como um todo, direcionando o capital aos seus usos mais socialmente produtivos, contribuindo para a alocação eficiente de capital na economia.

Os mercados são eficientes do ponto de vista da arbitragem, afirma Tobin (1987, p. 285). As correlações entre os preços no tempo são fracas para que possam ser economicamente exploradas. Contudo, a eficiência de arbitragem de informação não está isenta do aporte de recursos pelos arbitradores, especialistas e formadores de mercado. Já a eficiência na valoração dos fundamentos, definida como "precisão com que as avaliações do mercado refletem os fundamentos" (Tobin, 1987, p. 286) depende de expectativas e aquelas formadas racionalmente nem sempre são suficientes para justificar os movimentos do mercado (alta e baixa) ou mudanças nas taxas de desconto dos fluxos estimados.

Portanto, numa visão ampliada da Hipótese dos mercados eficientes para além das formas Forte, Fraca e Semiforte detalhadas por Fama (1970), o conceito de eficiência de mercado está relacionado à noção de que as forças de arbitragem estão operando constantemente. Se uma parte importante da informação relevante do ponto de vista de valor não tiver sido incorporada ao preço, então haverá forte incentivo econômico para que seja negociada. $O$ resultado das forças de arbitragem ajustará os preços até que reflitam completamente as informações disponíveis. Ainda que agentes individuais na economia ajam de maneira irracional, as forças de arbitragem redirecionarão os preços. A trajetória do preço é um processo e o preço corrente de um ativo é uma proxy incompleta do verdadeiro valor fundamental. Nesse caso, a preocupação dos pesquisadores deveria estar na "dinâmica da descoberta de preço pelo mercado"(C. M. C. Lee, 2001). O conceito de arbitragem precisa ser recolocado no contexto proposto por Lee (2001), o qual refere-se a negociações com base em informações, explorando as imperfeições de mercado e objetivando lucro. Embora alguns autores definam arbitragem como "estratégia de investimento líquido zero, livre

\footnotetext{
11 idem
} 
de risco que ainda gera lucro" (Bodie, Kane, \& Marcus, 2007, p. 991), em geral arbitragem envolve capital e risco (Shleifer \& Vishny, 1997).

A atividade de arbitragem depende, portanto, de erros na precificação (mispricing). Se de alguma forma mística as forças sobre os preços forçassem a que estes se ajustassem instantaneamente ao valor correto, então não haveriam arbitradores. Sendo assim, se a atividade de arbitragem depende de oportunidades a serem exploradas. Um mercado competitivo e livre depende de algum grau de ineficiência (C. M. C. Lee, 2001, p. 238).

Em relação à eficiência na valoração dos fundamentos, vários são os estudos que investigam a acurácia com a qual o mercado valora os fundamentos. Como referência nesse tema está o estudo conduzido por Shiller (1981), demonstrando que a volatilidade dos preços das ações é maior do que seria justificado por um modelo de valor presente dos dividendos esperados, apontando um caminho para a pesquisa em Finanças comportamentais (Shleifer, 2003). Tobin (1987, p. 286) assinala a onda aquisições de controle acionário (takeover), motivada pelas flagrantes subavaliações, como "testemunho da falência do mercado no seu critério de eficiência de valorar com base nos fundamentos". ${ }^{12}$

\subsection{Eficiência de mercado e finanças comportamentais}

Num mercado de capitais eficientes conforme proposto por Fama (1970) supõe-se que os preços das ações reflitam todas as informações disponíveis. Se parte de uma informação ainda não estiver incorporada ao preço, haverá enorme incentivo econômico para que investidores operem até que os preços espelhem todas as informações. Considerando que existem custos de transação e de obtenção da informação, os preços refletem as informações até que os custo marginais da transação e aqueles decorrentes da obtenção da informação se igualem ao benefício marginal. (Elton, Gruber, Brown, \& Goetzmann, 2009, p. 400).

A Hipótese dos Mercados Eficientes está fundamentada em argumentos que partem de pressupostos frágeis: 1) Assume-se que os investidores são racionais e avaliam as ações das empresas de forma racional; 2) Ainda que alguns investidores não sejam

12 "testimony to the failure of the Market on this fundamental valuation criterion of efficiency" (Tobin, 1987, p. 286) 
racionais, as operações por eles realizadas são aleatórias e cancelam-se entre si de tal forma que não afetam os preços; 3) Na medida em que os investidores são irracionais de maneira semelhante, deparam-se com investidores racionais os quais eliminam essas influências sobre os preços (Shleifer, 2003, p. 2).

É pelo mecanismo da arbitragem que os preços das ações são conduzidos na direção do seu valor fundamental (C. M. C. Lee, 2001). Além disso, entre as premissas de um mercado eficiente está a suposição de que muitos participantes do mercado buscam a maximização de lucro, analisam e valoram as ações de maneira independente. Como os investidores buscam a maximização de seus lucros, eles ajustarão os preços rapidamente (Reilly \& Brown, 2003, pp. 177-178).

Num mercado eficiente, os retornos esperados refletidos nos preços das ações estão ajustados ao risco de tal forma que a taxa de retorno esperada pelos os investidores que adquirem esses ativos, a preços informativamente eficientes, devem ser consistentes com o risco incorrido. Dessa forma, os investidores utilizam algum modelo de equilíbrio para ajustar risco e retorno (Reilly \& Brown, 2003, pp. 177-178).

Pesquisadores observaram que o mercado apresentava comportamento não compatível com as expectativas racionais do investidor e, consequentemente, com a Hipótese dos Mercados Eficientes. Consistiam em indícios de ineficiência do mercado ou de má especificação do modelo de equilíbrio dos retornos esperados, situações que passaram a ser denominadas "anomalias".

Anomalia, em economia financeira, consiste na observação de um comportamento que desvia da ordem comum ou natural, ou uma condição excepcional (Frankfurter \& McGoun, 2001, p. 412). Refere-se às evidências empíricas adequadamente explicadas e que contrariam a hipótese de eficiência de mercado. São resultados que surgem a partir da aplicação de um modelo de ajustamento da relação risco e retorno (usualmente o CAPM) para testar a eficiência de mercado (Ackert \& Deaves, 2009, p. $60)$.

No contexto financeiro, o termo "anomalia" foi usado por Ball (1992), com base em Kuhn (1970), para designar uma evidência sistemática que aparenta precisa do ponto de vista científico, mas inconsistente com os princípios da teoria de base, no caso em pauta, a Teoria dos Mercados Eficientes. 
Entre as anomalias apontadas na literatura está: 1) O excesso de volatilidade dos retornos não justificado por mudanças nas expectativas na distribuição de dividendos, relatada por Shiller (1981); 2) Aquela relacionada ao comportamento dos preços das ações nos dias subsequentes aos anúncios de resultados pelas empresas, relatada por Ball e Brown (1968) e replicada por autores como Foster, Olsen, \& Shevin (1984); 3) As evidências de que carteiras com ações de empresas que tem maior índice Valor Patrimonial/Valor da ação (B/V) tem historicamente pior retorno do que carteiras com menor índice B/V, encontradas por De Bondt e Thaler (1987), Fama e French (1992), Lakonishok et al. (1994) .

Anomalias, portanto, representam um desafio à Hipótese dos Mercados Eficientes e aos pressupostos de racionalidade, indicando sobrerreações (overreactions) ou subreações (underreactions) do mercado. São evidências da violação da teoria da eficiência de mercado, sugerindo que muitos investidores tomam decisões subótimas. Pessoas tendem a cometer erros de julgamento em condições de incerteza. Vários modelos teóricos têm sido apresentados para explicar as anomalias observadas como resultado da aversão ao risco. Entre elas está o excesso de confiança e outras heurísticas, identificadas por Tversky e Kahneman (1974), que são usadas pelos indivíduos quando da tomada de decisão em condições de incerteza (Elton et al., 2009).

Em relação às implicações comportamentais sobre da volatilidade, Black (1986) observa que a atuação de investidores que operam com base em ruído ${ }^{13}$ como se fosse informação, denominados noise traders, torna o mercado de certa forma ineficiente. Então o preço da ação se desvia de valor fundamental gerando um retorno específico (idiossincrático) que não está correlacionado com os fundamentos mas afeta a variabilidade dos retornos específicos, ou seja, afeta o risco idiossincrático.

\subsection{Modelos de precificação de ativos e os fatores de risco}

$\mathrm{Na}$ tentativa de prever o comportamento futuro dos retornos das ações, vários modelos de precificação de ativos de risco foram desenvolvidos apoiados na relação risco-retorno. O pano de fundo deles é a suposição de que deve ser possível modelar o retorno esperado com base nos fatores de risco a que esse ativo está exposto,

\footnotetext{
${ }^{13}$ Ruído, para Black (1986), é o oposto de informação
} 
minimizando a parcela não explicada. Entre os modelos de precificação de ativos de risco destacam-se o Capital Asset Pricing Model (CAPM), o modelo de três fatores de Fama e French e o Arbitrage Pricing Theory (APT).

Nos modelos mencionados, o risco de um ativo pode ser mensurado pela variabilidade dos retornos projetados em torno de uma média esperada. A variabilidade, por sua vez, é representada pelas medidas estatísticas variância ou desvio padrão.

Assumindo que o investidor racional maximiza sua utilidade, ele vai preferir, entre ativos com expectativas semelhantes de retorno, aquele que oferecer um menor risco. Por outro lado, um investidor racional exigirá um prêmio pelo risco para que se disponha a corrê-lo. Em condição de equilíbrio, o retorno esperado de um ativo de risco será proporcional ao risco assumido.

O risco total de um ativo de risco, medido pela variância dos retornos, pode ser decomposto em duas partes: o sistemático e o não sistemático (ou idiossincrático). 0 risco sistemático, também chamado de conjuntural decorre de fatores políticos, econômicos, sociais e afetando o retorno da maioria dos ativos. A outra parte, o risco não sistemático, decorre dos fatos que atingem diretamente $o$ ativo $e$, no caso das ações de uma empresa, está relacionado aos fatores próprios, idiossincráticos, e é influenciado pelas decisões dos gestores.

Supondo que o retorno esperado de uma carteira de ativos diversificada corresponda ao retorno esperado pela exposição aos fatores de risco do sistema e considerando ainda que exista uma relação linear entre o retorno esperado de um ativo de risco e o retorno da carteira diversificada, então a parte do retorno do ativo correlacionada com o retorno da carteira diversificada (que representa a carteira de todos os ativos existentes no mercado) corresponde ao risco sistemático. Já a parcela não correlacionada com o retorno da carteira diversificada corresponde, então, ao risco não sistemático (Sharpe, 1964).

A partir do modelo de seleção de carteiras conhecido como modelo de médiavariância e que foi desenvolvido por Markowitz (1959), Sharpe (1964) e Lintner (1956) e Mossin (1966) desenvolveram um modelo de precificação de ativos - Capital Asset Pricing Model (CAPM). O pressuposto subjacente é que em um mercado em 
equilíbrio, o retorno esperado de um ativo deve ser igual ao retorno do ativo livre de risco acrescido de um prêmio pelo risco a que o investidor está submetido.

O modelo de média-variância proposto por Markowitz (1959) supõe que os investidores esperam ser compensados pelo risco adicional assumido e a variância dos retornos é uma proxy do risco do ativo. Dessa forma é possibilitada a estruturação matemática da relação entre risco e retorno. O modelo assume que os investidores são avessos ao risco e quando escolhem ativos para comporem uma carteira, estão preocupados exclusivamente com a média e a variância do retorno sobre o investimento em um período à frente. Os investidores escolhem, então, carteiras eficientes do ponto de vista de média-variância. As carteiras ou minimizam a variância dos retornos ou maximizam o retorno, dada a variância. A teoria de carteiras de Markowitz(1952) fornece uma forma algébrica para determinar as proporções de cada ativo nas carteiras eficientes em termos de média e variância (Fama \& French, 2004).

O CAPM estabelece uma relação linear entre o retorno esperado e o retorno da carteira de mercado de tal forma que a sensibilidade do ativo em relação à carteira de mercado, medida pelo coeficiente beta da fórmula 1, consiste em uma medida de risco sistemático de tal forma que:

$$
E\left(R_{i}\right)=R_{f}+\beta \times\left[E\left(R_{r m}\right)-R_{l r}\right]
$$

Onde

$R_{f}$ é o retorno do ativo livre de risco

$E\left(R_{r m}\right)$ é o retorno esperado da carteira de mercado

$E\left(R_{i}\right)$ é o retorno esperado do ativo

$$
\beta=\frac{\operatorname{cov}\left(R_{j}, R_{m}\right)}{\sigma^{2}\left(R_{m}\right)}
$$

$\beta$ é o risco "sistemático" do ativo i e mede o grau de sensibilidade do ativo iem relação à carteira de mercado

Entretanto, evidências empíricas sugerem que outros fatores de risco como o porte da empresa, a relação entre o valor de contábil e o valor de mercado (índice B/M). 
Então, o modelo com um único fator como proposto no CAPM talvez não seja suficiente para explicar o retorno esperado de um ativo (Miller, 2000, p. 10).

Ball (1978) sustenta que a relação entre lucro e preço da ação é uma proxy para variáveis omitidas no CAPM. Tal evidência foi observada empiricamente por Basu (1983) tendo sido demonstrado que além do retorno de mercado e o porte da empresa, a relação lucro/preço explicava, em parte, as variações nos retornos das ações no mercado americano

Fama e French (1992) estudaram a influência do porte da empresa, da relação entre lucro e preço da ação (índice L/P), da alavancagem e do índice B/M sobre os retornos das ações. Os autores constataram que as variáveis: porte (ou valor de mercado das ações) e o índice B/M além do beta de mercado, em conjunto, têm um papel importante na explicação dos retornos das ações no período analisado.

A partir das evidências encontradas em Fama e French (1992), Fama e French (1993) formularam um modelo de precificação de ativos referenciado na literatura financeira como Modelo de 3-fatores. São eles: 1) Um fator relativo ao mercado (o beta de mercado conforme estabelece o CAPM); 2) Um fator relacionado ao porte da empresa, representado pelo valor de mercado das ações, 3) Um fator relacionado ao índice B/M (medido pela relação entre o valor contábil e o valor de mercado do patrimônio líquido). Os fatores 2) e 3) foram denominados "Small Minus Big" (SMB) e "High Minus Low" (HML), respectivamente.

No modelo de Fama e French (1993) o fator SMB refere-se ao prêmio pelo fator tamanho de tal forma que os retornos das empresas com menor valor de mercado (small-S) seriam menores do que das empresas maiores (big - B). Já o prêmio HML relaciona-se ao efeito da relação do valor patrimonial e o valor de mercado da ação (B/M). Foi observado que as ações com alto valor $B / M(h i g h-H)$ têm retornos maiores do que as empresas cujas ações apresentam baixo (low - L) índice B/M.

Para obter os fatores SMB e HML Fama e French (1993) formaram três carteiras agrupadas com base no valor de mercado e três outras carteiras com base na relação $\mathrm{B} / \mathrm{M}$ e calcularam os retornos mensais de cada carteira. $\mathrm{O}$ fator SMB foi obtido pela média aritmética dos retornos de cada uma das carteiras agrupadas pelo valor de mercado. Analogamente, o fator HML foi obtido pela média aritmética dos retornos 
das três carteiras formadas a partir do índice B/M. Embora existam evidências empíricas em favor da aplicabilidade do modelo de Fama e French (1993), Bornholt (2007, p. 70) aponta críticas ao modelo pelo empirismo na construção dos fatores tamanho e B/M e pelo fato de serem conhecidos ad-hoc, fato que enfraquece o modelo por falta de fundamentação teórica sobre a precificação de ativos. Além disso, o apelo prático é limitado na medida em que são necessárias estimativas confiáveis das sensibilidades aos fatores de risco.

O modelo matemático que representa a proposta de Fama e French (1993) é representado pela equação:

$$
R_{i, t}-R_{f, t}=a_{i}+b_{i}\left[R_{m, t}-R_{l r, t}\right]+s\left[S M B_{t}\right]+h\left[H M L_{t}\right]+e_{i, t}
$$

Onde

$R_{i, t}$ é o retorno do ativo i no mês $\mathrm{t}$

$R_{f, t}$ é o retorno do ativo livre de risco no mês $\mathrm{t}$

$S M B_{t}$ é o prêmio pelo fator tamanho, no mês $\mathrm{t}$

$H M L_{t}$ é o prêmio pelo fator $\mathrm{B} / \mathrm{M}$, no mês $\mathrm{t}$

Não obstante as críticas, o modelo de Fama e French (1993) tem sido utilizado inclusive em estudos da aplicabilidade do modelo para o mercado de capitais brasileiro e as evidências não são conclusivas (Argolo, Leal, \& Almeida, 2012; Lucena, P., \& Pinto \& Lucena, Pierri; Pinto, 2005; Málaga \& Securato, 2004; Mussa, 2012).

Argolo Leal e Almeida (2012) apontam desafios à aplicabilidade do modelo de três fatores para o mercado brasileiro, entre os quais está a dificuldade na formação de carteiras diversificadas para a construção dos fatores.

Já, o Arbitrage Pricing Theory (APT), desenvolvido por Ross (1976), está apoiado na "lei do preço único" a qual estabelece que o mesmo bem não pode ser vendido por preços diferentes. Isso porque, nesse caso, arbitradores comprariam o bem pelo preço mais baixo elevando-o e simultaneamente venderiam mais caro, direcionando o preço para baixo. Esse processo se manteria até que os preços do bem se igualassem (J. C. Francis, 1991, p. 295). 
O APT pressupõe que os retornos dos ativos resultam da influência de vários fatores, diferentemente do modelo mono fator que é o CAPM. Tanto o CAPM quanto o APT sugerem uma relação positiva entre risco e retorno esperado, embora a visão de risco embutida no APT seja mais genérica do que apenas o beta da ação em relação ao retorno de mercado (Stephen, Randolph, \& Jeffrey, 2002).

O APT de Ross (1976) está apoiado nas proposições:1) Os retornos dos ativos podem ser descritos por um modelo fatorial; 2) Existem ativos suficientes para eliminar os riscos idiossincráticos pela diversificação; 3) Existe um mercado de títulos com bom funcionamento para impedir oportunidades persistentes de arbitragem.

A determinação do número apropriado de fatores é a questão central do APT de Ross (1976) onde cada fator estrutural seria responsável pela geração de retornos observados e, consequentemente, seriam fontes de risco não diversificável. Roll e Ross (1980) verificaram estatisticamente que cinco fatores presumivelmente gerariam os retornos observados. Entretanto, ressaltam que se a relação preço-lucro tiver poder explicativo sobre os retornos dos ativos, então deverá ser substituída por um fator. Vale ressaltar que na metodologia detalhada por Roll e Ross (1980) para a implementação do modelo APT de Ross (1976), os fatores são obtidos pela aplicação da análise fatorial por máxima verossimilhança a partir dos retornos de um conjunto de ações. O modelo, originalmente proposto por Ross (1976) foi aperfeiçoado por Chen, Roll e Ross (1986) com a definição dos fatores macroeconômicos utilizados como variáveis explicativas: produção industrial, inflação inesperada, estrutura a termo dos juros.

As tentativas de construir um modelo que explique ex-post as variações dos retornos dos ativos de risco com base nas informações existentes ainda não superou 0 paradigma dominante sobre as variações de preços de ações que dizem respeito a: 1) Movimentos imprevisíveis dos fatores econômicos difusos; 2) Mudanças imprevisíveis no ambiente da empresa e no setor em que ela atua e 3) Eventos específicos da empresa e não previsíveis (Roll, 1988).

\subsection{Risco Idiossincrático, sincronicidade e comovimento}

A diferença entre risco de arbitragem, risco idiossincrático e risco não diversificável é que: o risco idiossincrático está associado, em geral, ao termo de erro nos modelos 
de precificação de ativos e o risco não diversificável é aquele que não pode ser eliminado pela diversificação (Wurgler \& Zhuravskaya, 2002) . O risco de arbitragem é a parcela da volatilidade da ação que não pode ser protegida (hedged), ou seja, a parte da volatilidade que arbitradores não podem evitar mantendo posições em outras ações ou índices (Mendenhall, 2004, p. 876).

Sincronicidade ou comovimento, nesta pesquisa corresponde à tendência dos preços das ações se moverem em conjunto com o mercado, setor, com outras ações, ou com fundamentos econômicos. Sincronicidade e risco idiossincrático têm em comum o fato de que em ambos a variabilidade dos retornos idiossincráticos faz parte da metodologia de mensuração, conforme detalhado adiante.

Morck et al. (2000) analisaram o comportamento das ações em várias economias e constataram que, em média, "os preços das ações se movem de maneira mais harmônica com o mercado nas economias pobres do que nas economias ricas"14. Baseados na constatação de que informações específicas incorporadas aos preços supostamente explicariam o risco idiossincrático, ou seja, a parcela das variações de preços não explicadas por fatores econômicos e setoriais, Morck et al. (2000) consideraram plausível a interpretação de que a menor sincronicidade ou maior risco idiossincrático corresponderia uma maior informatividade dos preços das ações que, por sua vez, estaria relacionada ao desenvolvimento econômico.

Para avaliar a sincronicidade Morck et al. (2000, p. 219) observaram em cada semana o número de ações cujos preços subiam e o número de ações cujos preços desciam e calcularam seguinte estatística:

$$
\begin{gathered}
\psi_{j t}=\ln \left(\frac{f_{i t}-0,5}{1-f_{i t}}\right) \\
f_{j t}=\frac{\max \left[n_{j t}^{u p}, n_{j t}^{d o w n}\right]}{n_{j t}^{u p}+n_{j t}^{d o w n}}
\end{gathered}
$$

14 "Stock prices move together more in poor economies than in rich economies" 
Onde $n_{j t}^{u p}$ é o número de ações no país j cujos preços subiram na semana t e $n_{j t}^{\text {down }} \mathrm{o}$ número de ações no país j cujos preços caíram na semana t.

A transformação logarítmica tem a função de transformar a escala de valores do intervalo $[0,5 ; 1]$ para o conjunto dos números reais, de menos infinito até mais infinito.

A sincronicidade também foi medida a partir dos coeficientes de determinação $R^{2}$ das regressões para cada país:

$$
r_{i t}=\alpha_{i}+\beta_{1, t} r_{m, j t}+\beta_{2, t}\left[r_{U S, t}+e_{j t}\right]+\varepsilon_{i t}
$$

Onde i corresponde ao índice da firma, j um índice de mercado do país, t corresponde a um período de uma semana, $r_{m, j t}$ o retorno do mercado estadunidense, ejt é a taxa de variação na taxa de câmbio por U.S. dólar.

A regressão especificada acima é similar à equação clássica de precificação de ativos. Como o enfoque daqueles autores era a comparação entre os países em relação ao mercado estadunidense, a expressão $\left[\mathrm{r}_{\mathrm{US}, \mathrm{t}}+\mathrm{e}_{\mathrm{jt}}\right]$ traduziu o retorno do mercado estadunidense em moeda do país cuja sincronicidade se está medindo.

$$
\begin{gathered}
\gamma_{j}=\ln \left(\frac{1-\psi_{j t}}{\psi_{j t}}\right) \\
\text { Onde } \boldsymbol{\psi}_{j t}=\mathbf{1}-\boldsymbol{R}^{2}
\end{gathered}
$$

A variável $\psi_{j t}$ é a estimativa da variabilidade dos retornos específicos da firma j no período t e equivale a $\left(1-R^{2}\right)$. Por sua vez, $R^{2}$ é o coeficiente de determinação da regressão do retorno da ação em relação às variáveis macroeconômicas explicativas, semelhante aos modelos de precificação de ativos. Note-se que enquanto a sincronicidade refere-se à tendência dos preços se moverem em conjunto com os fatores sistemáticos, o indicador $1-\mathrm{R}^{2}$ mede a não-sincronicidade. Então, a nãosincronicidade refere-se à parcela dos retornos idiossincráticos, ou seja aqueles explicados pelos fatores sistemáticos, ou seja: o risco idiossincrático. 
Sabe-se que o coeficiente de determinação de uma equação de regressão tem valor entre 0 e 1. Para solucionar problemas econométricos foi aplicada a transformação logarítmica indicada na fórmula 7: $\gamma_{j}=\ln \left(\frac{1-\psi_{j t}}{\psi_{j t}}\right)$. Isso porque a distribuição de $\psi_{j \mathrm{jt}}$ é negativamente assimétrica e leptocúrtica (Art Durnev, Morck, \& Yeung, 2004, p. 70).

Durnev et al. (2004) avaliaram a eficiência dos investimentos corporativos de capital quando os preços das ações são mais informativos. Usaram uma medida de nãosincronicidade para avaliar a informatividade dos preços das ações, sob a hipótese de que preços das ações mais informativos conduzem sinais significativos da qualidade das decisões dos gestores.

Para medir as variações específicas dos retornos das ações foi usada a regressão dos retornos da empresa i no setor $\mathrm{j}$, ri,j,t, sobre os retornos do mercado e do setor industrial $\mathrm{r}_{\mathrm{m}, \mathrm{t}}$ e $\mathrm{r}_{\mathrm{i}, \mathrm{t}}$, respectivamente de tal forma que:

$$
r_{i, j, t}=\beta_{j, 0}+\beta_{j, m} r_{m, t}+\beta_{j, i} r_{i, t}+\varepsilon_{i, j, t}
$$

Os índices de mercado e do setor foram obtidos com base em médias ponderadas excluindo a empresa em questão. Assim foram prevenidas correlações espúrias entre os retornos da empresa e o setor naqueles setores com poucas empresas.

Analogamente ao estudo conduzido por Morck et al. (2000), foi aplicada a transformação logarítmica de tal forma que a medida de não-sincronicidade, calculada com base no 10: coeficiente de determinação da regressão é dada pela fórmula

$$
\Psi_{\mathrm{jt}}=\ln \left(\frac{1-R_{i}^{2}}{R_{i}^{2}}\right)
$$

Cabe observar que o coeficiente de determinação da equação de regressão, $\mathbf{R}^{2}$, é uma medida da parcela de variação explicada pelas variáveis independentes da regressão e pode ser 11.

escrito como a fórmula 


$$
R^{2}=1-\frac{S Q R}{S Q T}=1-\frac{\text { variação } n a ̃ o \text { explicada }}{\text { variação total }}=1-\frac{\sum \varepsilon_{i, j, t}^{2}}{\sum\left(r_{i, j, t}-\bar{r}_{i, j, t}\right)^{2}}
$$

Onde $\sum \varepsilon_{i}^{2}$ é a variação não explicada pelo modelo que descreve a linha de regressão, ou simplesmente soma dos quadrados dos resíduos (SQR); $\bar{r}_{i, j, t}$ é o retorno médio e $r_{i, j, t}$ é o retorno observado. $\sum\left(r_{i, j, t}-\bar{r}_{i, j, t}\right)^{2}$ é a soma total dos quadrados (SQT) que corresponde à variação total dos retornos observados em relação à média da amostra, ou ainda a soma dos quadrados devido à regressão (Gujarati, 2006).

A medida de sincronicidade proposta por Morck, Yeung, \& Yu, (2000) tem sido amplamente utilizada em pesquisas sobre comportamento dos preços das ações como em Bartram, Brown e Stulz (2012), Brockman e Yan (2009); Chan \& Hameed (2006), Chen, Goldstein e Jiang (2007), Chen, Huang e Jha (2012); Dasgupta, Gan, e Gao (2010); Dewally e Shao (2012), Durnev e Guriev (2011), Durnev et al.(2003); Gul, Kim e Qu(2011); Haggard, Martin e Pereira(2008); Han, Lin e Wei (2010); He (2011); Hsin e Tseng (2012); Khanna e Thomas (2009); Piotroski e Roulstone (2004); Riedl e Serafeim (2011), Veldkamp \& Wolfers (2007); Wurgler (2000) entre outros.

Em Bissessur e Hodgson (2012) e em Gul, Srinidh e Ng (2011) a medida derivada da sincronicidade foi usada para inferir o risco idiossincrático, e Kong, Xiao, \& Liu (2011) usaram (1-R $\left.{ }^{2}\right)$ como medida de risco idiossincrático, a qual guarda estreita relação com a medida de sincronicidade proposta por Morck et al. (2000) ${ }^{15}$.

Alternativamente, Campbell, Lettau e Malkiel (2001) propuseram uma forma decompor a volatilidade agregada ${ }^{16}$ entre os seus componentes sem a necessidade de estimar a covariâncias entre indústrias ou empresas. Considerando que o retorno do mercado é um dos componentes do retorno de um ativo, a volatilidade foi decomposta em três componentes: mercado, setor (indústria) e o específico da empresa (firma). Então a média ponderada das variâncias das empresas do mercado (ou a volatilidade agregada das empresas) é desmembrada entre a volatilidade

\footnotetext{
15 No tópico 2.7: Relação entre risco idiossincrático e sincronicidade $\left(\boldsymbol{\psi}_{j t}\right)$, a relação entre sincronicidade e risco idiossincrático está matematicamente demonstrada.

${ }^{16}$ Segundo Campbell et al. (2001, p. 1), volatilidade agregada é "a volatilidade vivida pelos detentores de fundos agregados de índices" ("volatility experienced by holders of aggregate index funds")
} 
agregada no nível do mercado, no nível do setor (indústria) e no nível das empresas e dada pela fórmula:

$$
\begin{aligned}
\sum_{i} w_{i t} \sum_{j \in i} w_{j i t} \operatorname{Var}\left(R_{j i t}\right) & =\operatorname{Var}\left(R_{m t}\right)+\sum_{i} w_{i t} \operatorname{Var}\left(\varepsilon_{i j t}\right)+\sum_{i} w_{i t} \sigma_{\eta i t}^{2} \\
& =\sigma_{m t}^{2}+\sigma_{\varepsilon t}^{2}+\sigma_{\eta t}^{2}
\end{aligned}
$$

e

$$
\begin{gathered}
\sigma_{\eta t}^{2}=\sum_{i} w_{i t} \sigma_{\eta i t}^{2}=\sum_{i} w_{i t} \sum_{j \in i} w_{j i t} \sum_{s \in t}\left(R_{j i t}-R_{j t}\right)^{2} \\
\sigma_{\varepsilon t}^{2}=\sum_{i} w_{i t} \operatorname{Var}\left(\varepsilon_{i j t}\right)=\sum_{i} w_{i t} \sum_{s \in t}\left(R_{i t}-R_{t}\right)^{2} \\
\sigma_{m t}^{2}=\operatorname{Var}\left(R_{m t}\right)=\sum_{s \in t}\left(R_{t}-\mu\right)^{2}
\end{gathered}
$$

Onde:

$\sigma_{m t}^{2}$ é a volatilidade do mercado $\left(\mathrm{MKT}_{\mathrm{t}}\right)$

$\sigma_{\varepsilon t}^{2}$ é a volatilidade agregada dos setores, obtida como a média ponderada das volatilidades de todos os setores i no mercado (INDt)

$\sigma_{\eta t}^{2}$ é a volatilidade agregada das empresas, obtida como a média ponderada de todas as volatilidades das j empresas, calculada como pela a soma dos quadrados dos retornos residuais das empresas em relação ao setor em que atuam. (FIRMt)

$w_{i t}$ é o peso do setor i no total do mercado no dentro do período $t$

$w_{j i t}$ é o peso da empresa j no setor i no dentro do período $t$ 
$\operatorname{Var}\left(R_{i j t}\right)$ é a variância do excesso de retorno ${ }^{17}$ da empresa $j$ no setor $i$ no período $t$ $\operatorname{Var}\left(R_{m t}\right)$ é a variância do excesso de retorno do mercado no período $t$

$R_{j i t}$ é o excesso de retorno da empresa $j$ no setor $i$ no período $t$

$R_{i t}$ é o excesso de retorno do setor $i$ no período $t$

$\mu$ é o excesso de retorno médio do mercado no período $t$

Com base na decomposição acima, Brockman, Liebenberg, \& Schutte (2010); obtiveram a medida de comovimento com base na relação entre a volatilidade idiossincrática agregada em relação à volatilidade total, ou seja:

$$
\text { comovimento }_{t}=1-\frac{\text { IIRM }_{t}}{\text { MKT }_{t}+I N D_{t}+\text { FIRM }_{t}}
$$

Cabe salientar que a medida acima descreve o comovimento analisado de maneira agregada e é usado para comparar o grau de comovimento médio dos retornos das ações das empresas ao longo do tempo ou para comparar o comovimento entre economias. A metodologia proposta por Campbell et al.(2001) em que a volatilidade é decomposta sem a necessidade de estimar a covariância para setores e empresas é válida para qualquer ponderação, desde que o retorno de mercado seja calculado usando a mesma ponderação. Contudo, tal metodologia não se adapta a análise do comovimento de uma empresa em relação ao mercado.

Em várias pesquisas (Brandt, Brav, Graham, \& Kumar, 2009; G. Brown \& Kapadia, 2007; C. Cao, Simin, \& Zhao, 2006; Guo \& Savickas, 2008; Irvine \& Pontiff, 2007) foi usada a medida da volatilidade idiossincrática agregada proposta por Campbell et al.(2001).

A volatilidade dos retornos idiossincráticos corresponde, então, ao desvio padrão dos retornos idiossincráticos em cada período analisado. Cabe ressaltar que a especificação dos fatores sistemáticos afeta a definição do risco idiossincrático que será medido. Foi usado o modelo de três fatores de Fama-French (1993) para

\footnotetext{
${ }^{17}$ Excesso de retorno é medido sobre a taxa do título do tesouro (Campbell et al., 2001, p. 4)
} 
precificação de ativos em estudos como: Ang, Hodrick, Xing e Zhang (2006), Armstrong, Core, Taylor e Verrecchia (2011); C. Chen et al. (2012), Z. Chen e Petkova (2012), Fu (2009), Jiang et al. (2009), Kelly, Lustig, e Van Nieuwerburgh (2012); Peterson e Smedema (2011).

Ferreira e Laux (2007), Armstrong, Balakrishnan, e Cohen (2012), An, Cook, \& Zumpano (2011), Jin e Myers (2006), Villalonga e Amit (2006), Hou, Dijk, Zhang, e Van Dijk (2012), Zhang (2010), An et al.(2011), Bushee e Noe(2000), Doukas, Kim, \& Pantzalis (2010), Kumar e Lee (2006), Bali e Cakici (2009), Bali, Cakici, Zhang e Xuemin Yan (2005), Ali, Hwang e Trombley (2003), Taylor (2008) usaram o desvio padrão dos erros da regressão do excesso de retorno da ação em relação ao excesso de retorno do mercado para avaliar o risco idiossincrático.

O modelo usado por Arena, Haggard, e Yan (2008), Wurgler e Zhuravskaya (2002) para calcular o risco idiossincrático tem como variáveis explicativas o retorno do mercado (analogamente ao CAPM) e o retorno do mercado defasado.

Lee e Liu (2011) acrescentam o retorno do setor como explicativo do retorno da ação e analogamente usam o coeficiente de determinação, $\left(1-R^{2}\right)$, como medida do risco idiossincrático.

\subsection{Relação entre risco idiossincrático e sincronicidade $\left(\psi_{j t}\right)$}

Roll (1988) se propôs a responder a seguinte questão em sua pesquisa: "É realmente verdade que podemos explicar os movimentos correntes nos preços das ações pelas grandes influências econômicas, pelas influências do setor e pelas notícias dos eventos específicos sobre a empresa?"18 Ele salientava a importância dos fatores sistemáticos nas teorias de precificação de ativos como Capital Asset Pricing Model (CAPM) e o Arbitrage Pricing Theory (APT). Além disso, um número maior de fatores deveria ser capaz de explicar uma parcela maior da volatilidade do retorno do que um único fator, embora tanto CAPM quanto APT tenham, em geral, um parco poder explicativo, conforme demonstrado ao longo daquela pesquisa.

${ }_{18 "}$ Is it really true that we can explain the actual price movements of individual common stocks by broad economic influences, industry influences, and specific news events about the firm?"(Roll, 1988, p. 542) 
Explicações, como o tamanho da empresa, foram investigadas considerando que empresas de grande porte seriam mais diversificadas, operando em mais de um segmento de mercado se aproximariam a um portfólio de empresas, fato que justificaria um $\mathrm{R}^{2}$ maior. Verificou que nas grandes empresas o retorno das ações era melhor explicado pelo mercado do que nas empresas menores. Em seguida Roll (1988) avaliou o impacto das notícias específicas da empresa divulgada na mídia sobre a volatilidade remanescente (ou a volatilidade especifica, após excluir os fatores econômicos). Para tanto, excluiu da série de dados de cada empresa as observações correspondentes às datas em que notícias foram publicadas e verificou um aumento na estatística $R^{2}$ do modelo de precificação de ativos. Isso indicava que parte das variações específicas do retorno da empresa seria resultante da incorporação de informações públicas e especificas aos preços.

Ainda assim, restavam variações não explicadas e específicas de cada empresa. Roll (1988) levantou as hipóteses de que poderiam indicar a existência ou de informações privadas incorporadas aos preços ou então de frenesi do mercado não relacionado concretamente a informações, referindo-se ao que Black (1986) descreveu como atuação de noise traders.

Segundo a Hipótese dos Mercados Eficientes (Fama, 1976), o preço das ações reflete as informações disponíveis sobre as empresas. Roll (1988) demonstrou que a quantidade relativa de informação do mercado e do setor incorporada aos preços das ações influencia o grau com que os preços das ações de diferentes empresas se movem em conjunto, de forma harmônica. Além disso, o efeito das informações específicas das empresas incorporadas aos preços das ações seria uma plausível explicação para o mercado e o setor não serem suficientes para explicar a totalidade das variações dos preços das ações. Roll (1988), portanto, atribuiu os baixos valores da estatística $R^{2}$ geralmente observados na aplicação dos modelos de precificação dos ativos à incorporação das informações específicas divulgações sobre empresa nos preços. A pesquisa de Roll (1988) foi o primeiro estudo a considerar a possibilidade de a estatística $R^{2}$ estar relacionada a informações específicas das empresas. 
O retorno específico (ou idiossincrático) corresponde à parcela do retorno da ação que não pode ser explicada pelos fatores sistemáticos, como já esclarecido. Matematicamente corresponde ao erro do modelo de precificação de ativos como o CAPM, modelo de 3-fatores da Fama e French, APT ou outro modelo de precificação de ativos. Vale lembrar que o retorno idiossincrático depende dos fatores sistemáticos incluídos no modelo. Considerando que o retorno de um ativo é uma função linear dos fatores sistemáticos conforme pressupões os modelos como CAPM e APT, entre outros, se o retorno "Ref" de um ativo "" é explicado pelo retorno "R" dos "k" fatores tem-se:

$$
\begin{gathered}
\operatorname{Ret}_{i}=\beta_{0}+\sum_{j=1}^{k} \beta_{j} \operatorname{Ret}_{j}+\varepsilon_{i} \\
\operatorname{Ret}_{i}=\beta_{0}+\beta_{1} \operatorname{Ret}_{1}+\beta_{2} \operatorname{Ret}_{2}+\varepsilon_{i}
\end{gathered}
$$

Para efeito de demonstração, será usado um modelo de dois fatores, de tal forma que:

Aplicando o operador de variância tem-se:

$$
\begin{aligned}
& \operatorname{Var}\left(\operatorname{Ret}_{i}\right)=\operatorname{Var}\left(\beta_{0}\right)+\operatorname{Var}\left(\beta_{1} \operatorname{Ret}_{1}\right)+\operatorname{Var}\left(\beta_{2} \operatorname{Ret}_{2}\right)+\operatorname{Var}\left(\varepsilon_{i}\right) \\
& \text { e } \\
& \operatorname{Var}\left(\epsilon_{i}\right)=\frac{\sum_{t=1}^{n}\left(\operatorname{Ret}_{i t}-\widehat{\operatorname{Ret}_{l t}}\right)^{2}}{n-k-1}=\frac{\sum_{t=1}^{n} \varepsilon_{i}{ }^{2}}{n-k-1}=\sigma_{\varepsilon}^{2}= \\
& \text { Variância Idiossincrática Absoluta } \\
& \sqrt{\operatorname{Var}\left(\epsilon_{i}\right)}=\sigma_{\varepsilon}=\text { Risco Idiossincrático Absoluto } \\
& \operatorname{Var}\left(\operatorname{Ret}_{i}\right)=\frac{\sum_{t=1}^{n}\left(\operatorname{Ret}_{i t}-\overline{\operatorname{Ret}}_{i t}\right)^{2}}{n-1}=\sigma_{\text {ret }}{ }^{2}=\text { Variância Total } \\
& \sqrt{\operatorname{Var}\left(\operatorname{Ret}_{i}\right)}=\sigma_{\text {ret }}=\text { Risco Total }
\end{aligned}
$$

Por outro lado, 


$$
\begin{gathered}
R^{2}=\text { coeficiente de determinação da regressão } \\
R^{2}=1-\frac{S Q R}{S Q T} \Rightarrow 1-R^{2}=\frac{S Q R}{S Q T}=\text { medida de não }- \text { sincronicidade } \\
\equiv \text { Risco Idiossincrático }
\end{gathered}
$$

A medida de não-sincronicidade corresponde ao percentual das variações do retorno da ação não explicada pelos fatores sistemáticos. Refere-se à parcela idiossincrática das variações, ou seja, ao risco idiossincrático. Analogamente, a sincronicidade dos preços das ações refere-se ao percentual dos retornos da ação explicado pelos fatores sistemáticos. Desse modo tem-se:

$$
S Q T=\sum\left(\operatorname{Ret}_{i}-\overline{\operatorname{Ret}}_{i}\right)^{2} \text { e } S Q R=\sum \varepsilon_{i}^{2}
$$

Se SQT for dividido por ( $n-1)$ tem-se

$$
\frac{S Q T}{n-1}=\frac{\sum\left(\operatorname{Ret}_{i}-\overline{\operatorname{Ret}}_{i}\right)^{2}}{n-1}=\operatorname{Var}\left(\operatorname{Ret}_{i}\right)
$$

Se SQR for dividido por (n-k-1) tem-se

$$
\frac{S Q R}{n-k-1}=\frac{\sum \varepsilon_{i}{ }^{2}}{n-k-1}=\operatorname{Var}\left(\varepsilon_{i}\right)
$$

Então,

$$
\begin{gathered}
1-R^{2}=\frac{S Q R}{S Q T}=\frac{\sum \varepsilon_{i}{ }^{2}}{\sum\left(\operatorname{Ret}_{i}-\overline{R e t}_{i}\right)^{2}}=\frac{\sum \varepsilon_{i}{ }^{2}}{\sum\left(\operatorname{Ret}_{i}-\overline{R e t}_{i}\right)^{2}} \times \frac{n-k-1}{n-k-1} \times \frac{n-1}{n-1} \\
1-R^{2}=\frac{\sum \varepsilon_{i}^{2}}{n-k-1} \times \frac{n-1}{\sum\left(\operatorname{Ret}_{i}-\overline{R e t}_{i}\right)^{2}} \times \frac{n-k-1}{n-1} \\
=\frac{\frac{\sum \varepsilon_{i}{ }^{2}}{n-k-1}}{\frac{\sum\left(\operatorname{Ret}_{i}-\overline{R e t}_{i}\right)^{2}}{n-1}} \times \frac{n-k-1}{n-1}
\end{gathered}
$$




$$
\begin{gathered}
1-R^{2}=\left(\frac{\sigma_{\varepsilon}}{\sigma_{\text {ret }}}\right)^{2} \times \frac{n-k-1}{n-1}= \\
1-R^{2}=\left(\frac{\text { risco idiossincrático absoluto }}{\text { risco total }}\right)^{2} \times \frac{n-k-1}{n-1}
\end{gathered}
$$

Mas se "n" é grande em relação a "k" (ou seja, se o número de observações for grande em relação ao número de fatores sistemáticos no modelo), então

$$
\frac{n-k-1}{n-1} \cong 1 \Rightarrow 1-R^{2}=\left(\frac{\text { risco idiossincrático absoluto }}{\text { risco total }}\right)^{2}
$$

$0 \leq\left(1-R^{2}\right) \leq 1$

Portanto a medida da não-sincronicidade pode ser obtida pelo quadrado da relação entre risco idiossincrático e a volatilidade total ${ }^{19}$. Quanto maior o risco idiossincrático, maior a não-sincronicidade dos preços da ação, menor o comovimento, tudo o mais permanecendo constante.

\subsection{Risco idiossincrático, sincronicidade e alocação de capital na economia}

A ligação entre desenvolvimento econômico e o setor financeiro tem sido amplamente discutida. A sua importância para o crescimento deriva do fato de que o mercado financeiro preenche funções como de importante intermediário na transferência da poupança para investimentos (Bencivenga, Smith, \& Starr, 1996; Goldsmith, 1955; Levine \& Zervos, 1998; Levine, 1997). Os mercados financeiros promovem liquidez (Bencivenga \& Smith, 1991; Chun, Kim, Morck, \& Yeung, 2008; Levine, 1991), permitindo a redução de risco por meio da diversificação e atuam como propagadores de informações (Boyd \& Prescott, 1986; Diamond, 1984). A importância dos mercados financeiros para o crescimento econômico está ligada ao fato de preencher funções

${ }^{19}$ Considerando que o número de observações para construir o modelo é grande em relação ao número de fatores sistemáticos que explicam o retorno da ação. 
acima descritas além de favorecerem que o capital seja direcionado aos usos de maiores retornos (J. Greenwood \& Smith, 1997), permitindo que a poupança favoreça a acumulação de capital (R. Greenwood, 2008).

Por outro lado, alocação eficiente de capital significa que o capital está sendo direcionado a projetos que criam valor e retirado daqueles projetos menos economicamente atrativos, como resultado das pressões dos investidores externos. Estes estimulam os gestores a buscarem políticas de investimentos que maximizem o valor para o acionista (M. C. Jensen, 1986). Além do que, a redução das fricções derivadas da assimetria de informações faz parte do rol de papéis do setor financeiro para maximizar o valor das decisões tomadas pelos gestores.

Já o aumento da assimetria informacional impacta o risco de liquidez, inibindo a liquidez do mercado como consequência das incertezas associadas à conversão de ativos em meios de troca. Por outro lado, na presença de informações específicas da empresa a partilha e proteção em relação a riscos são facilitadas. Isso porque nos mercados de capitais líquidos, além dos custos de transação serem mais baixos, é menor a incerteza em relação à transação de compra e venda poder ser realizada. Muitos investimentos de longo prazo não poderiam ser concretizados em um mercado de capitais com baixa liquidez, pois os detentores de poupança não se sentiriam estimulados a vincular seus recursos a esses investimentos por um período longo de tempo. Contudo a situação seria diversa se os poupadores pudessem rapidamente vender suas ações no mercado secundário e levantar capital em condições razoáveis (Levine, 1997). Dessa maneira as informações específicas das empresas incorporadas aos preços, agregadas e disseminadas pelos mercados de capitais, afetam a liquidez dos mercados e a alocação de capital na economia e consequentemente impactam o crescimento econômico.

Segundo Myers e Majluf (1984), quando os investidores têm menos informações do que os gestores sobre o valor fundamental, comportam-se de forma a reduzir o preço das ações no momento em que a empresa tenta levantar recursos com nova emissão. Inferem que as ações estão sobreavaliadas e presumem que se os gestores têm interesse na emissão de novas ações deve indicar que o preço está elevado, ajustando-o, então, para baixo. Tal redução, em decorrência do comportamento dos investidores menos informados do que os gestores, eleva o custo do financiamento 
dos projetos e torna os papéis dessa empresa menos interessantes. Decorre daí um subinvestimento, pois os gestores têm dificuldade de financiar projetos que podem gerar valor.

Consequentemente, o desenvolvimento econômico é favorecido por um mercado mais eficiente, ou seja, no qual as informações sejam refletidas nos preços de maneira mais rápida e eficiente. Mercados mais eficientes proporcionam melhor alocação de capital na economia, promovendo o desenvolvimento econômico. Vale lembrar que a eficiência da avaliação fundamental (Fundamental valuation efficiency) é uma das formas de eficiência de mercado definida por Tobin (1987, p. 286) como "precisão com que as avaliações do mercado refletem os fundamentos".

Para alguns autores, a uma menor sincronicidade (maior risco idiossincrático ) está associada uma maior informatividade dos preços e uma alocação mais eficiente de capital na economia (Barberis, Shleifer, \& Wurgler, 2005; Artyom Durnev, Morck, \& Yeung, 2000; Artyom Durnev et al., 2003). Na direção oposta, na pesquisa de Dasgupta et al. (2010) os resultados indicaram que maior transparência das empresas leva a uma maior sincronicidade. Nos estudos acima mencionados a transparência corporativa ou a qualidade do ambiente informacional foram avaliados de maneira indireta, com base na acurácia das previsões de analistas, na qualidade da auditoria externa ou em indícios de gerenciamento de resultados.

Wurgler (2000) encontrou evidências de que à menor sincronicidade está associada alocação de capital mais eficiente e interpretou a medida de não-sincronicidade (correspondente ao risco idiossincrático) como proxy para o grau de informações específicas das empresas incorporadas aos preços. Concluiu que a alocação de capital é melhorada nos países onde o mercado de capitais incorpora nos preços mais informações específicas sobre as empresas. Observou também que em mercados secundários eficientes, os investidores podem distinguir melhor bons dos maus projetos utilizando mecanismos como $Q$ de Tobin. Dessa forma os mercados em que a alocação de capital se mostrou mais eficiente também foram aqueles em que os preços das ações estavam menos sincronizados. Vale lembrar que a alocação eficiente de capital indica que recursos da economia são direcionados a projetos em que se espera geração de valor, em detrimento daqueles com poucas expectativas de retorno. Os resultados obtidos sugerem que os mercados de capitais das economias 
desenvolvidas têm preços mais informativos supostamente devido à facilidade proporcionada pela liquidez do mercado e dos reduzidos custos de transação. Naquele estudo foi usada a medida do risco idiossincrático $\left(1-R^{2}\right)$ como proxy das informações específicas incorporadas aos preços. Os autores também verificaram que mercados financeiros mais líquidos são aqueles que têm alocação de capital mais eficiente, conforme teorizado por Levine (1997).

Outras pesquisas apontam para as evidências empíricas de que gestores de empresas nas quais as ações têm maior risco idiossincrático tomam decisões de investimentos mais eficientes (Q. Chen et al., 2007; Art Durnev et al., 2004, p. 66) e que os preços das ações são mais informativos em relação aos lucros futuros (Artyom Durnev et al., 2003). Se o preço das ações reflete as informações disponíveis (Hipótese dos mercados eficientes), o movimento nos preços das ações deve estar relacionado às informações que fluem dos gestores para os investidores que, por sua vez são influenciados pelas alternativas de solução dos conflitos entre gestores e esses investidores.

Durnev et al. $(2004 ; 2003)$ demonstram que as empresas que usam mais intensamente financiamentos externos e são mais eficientes na alocação de capital também são aquelas que apresentam menor sincronicidade nos preços das ações. A interpretação é que os arbitradores informados tenderão direcionar as atenções às empresas em que as informações específicas estão mais intensamente incorporadas nos preços das ações. Por essa razão, acompanharão de perto os fundamentos. Os autores examinaram a relação entre a sincronicidade e as medidas contábeis que indicavam informatividade em relação ao desempenho futuro. Verificaram que a sincronicidade era menor para as empresas em que os preços continham informações sobre os lucros futuros. Demonstrando, portanto, que as variações de preços não explicadas pelos movimentos do mercado ou do setor referiam-se às informações específicas da empresa incorporadas aos preços da ação.

Durnev et al.(2003, p. 798) definiram informatividade do preço (price informativeness) como "quanta informação o preço da ação contém acerca dos lucros futuros". Vale lembrar que segundo a teoria de finanças, os fundamentos de uma ação "são os dividendos ou outras remunerações [...] sobre os lucros futuros esperados. O valor da ação é o valor presente descontado de ambos os fluxos". Uma condição necessária 
para que o mercado de capitais exiba eficiência funcional é a de que os preços das ações estejam atrelados fortemente aos fundamentos da firma (Tobin, 1987, p. 286).

Além disso, cabe salientar que a medida $R^{2}$ detalhada em Roll (1988) também foi usada para avaliar o grau de informações específicas incorporadas aos preços por Stowe e Xing (2011), Alves, Peasnell, e Taylor (2010), Chun, Kim, Morck e Yeung (2008), Gul, Srinidhi e Ng (2011); Kaniel, Ozoguz e Starks (2012).

\subsection{Risco idiossincrático, sincronicidade e fluxo de informações}

Lançando olhar no ambiente do mercado de capitais, entende-se que o retorno das ações refletem as informações disponíveis (Hipótese dos mercados eficientes, teoria estabelecida por Fama em 1970) e, portanto espelham as expectativas sobre os lucros futuros (Collins, Kothari, Shanken, \& Sloan, 1994; Artyom Durnev et al., 2003; Kothari \& Sloan, 1992). Esta visão desperta a atenção dos pesquisadores na medida em que a intensidade com que as informações sobre o lucro futuro estão incorporadas nos preços das ações indica a relevância atribuída pelo mercado das informações disponíveis aos investidores (Haw, Hu, Lee, \& Wu, 2012). Ou seja, se o preço da ação está próximo ao valor presente dos lucros que estão por ser reconhecidos, significa que o mercado estimou e precificou razoavelmente o desempenho futuro. Logo, as informações disponibilizadas foram úteis para a estimação dos benefícios futuros.

Já, os investidores estimam os benefícios futuros com base nas informações disponíveis e incompletas uma vez que os gestores disponibilizam, ao público, somente parte das informações sobre a empresa. Eles disponibilizam de forma voluntária (evidenciação voluntária) ou por determinação legal - por força da Lei das S/A's. Como os gestores têm informações mais completas do que os investidores, estes se deparam com o problema decorrente da assimetria de informações. Assimetria de informações surge quando uma das partes envolvidas em uma transação tem mais informações do que as demais acerca das características dos bens ou serviços a serem transacionados.

Considerando que os investidores dispõem de informações incompletas, eles avaliarão as empresas pelo pior cenário possível (situação descrita por Akerlof (1970) 
em seu trabalho intitulado "Market for Lemons ${ }^{20}$ ). Portanto, existe aqui um problema não resolvido na teoria nem na prática que diz respeito à relevância do fluxo de informações dos gestores para os investidores de forma a maximizar o bem estar dos dois grupos de interesses.

O fluxo de informações é influenciado pelo grau de transparência da empresa em relação ao mercado, sendo "transparência" definida por Bushman et al. (2004, p. 210) como:

[...] a ampla disponibilização das informações específicas, relativamente a empresas de capital aberto, disponibilizadas aos externos à empresa. Nesse quadro, classificamos os mecanismos de informação em três categorias: divulgação corporativa, aquisição de informação privada e disseminação de informação. Divulgação corporativa envolve divulgação de informação específica da empresa em base voluntária ou obrigatória." ${ }^{21}$

Pela teoria financeira, os investidores perseguem o valor fundamental da empresa e esse valor fundamental (ou intrínseco) é função dos lucros futuros. Ou seja, por meio dos movimentos de compra e venda das ações, os investidores conduzem ou distanciam o preço da ação do seu valor fundamental. Para estimar o valor fundamental das empresas os investidores se valem de informações cujo risco dela não refletir os fundamentos é precificado, afeta o custo de capital e é não-diversificável (Easley \& Hara, 2004). O risco informacional, por sua vez, diz respeito à "probabilidade de que uma informação específica da firma que é relevante para decisões de precificação dos investidores seja de má qualidade" 22 (J. Francis, LaFond, Olsson, \& Schipper, 2005).

Portanto, entender como as informações específicas das empresas são incorporadas aos preços das ações é uma questão relevante para pesquisadores em contabilidade e em finanças. Alguns estudos procuram demonstrar que a sincronicidade dos preços das ações (ou a medida alternativa: o risco idiossincrático) está relacionada com o

20 O título poderia ser traduzido como Mercado dos Abacaxis. No título, lemons refere-se ao que nos Estados Unidos corresponde a um mercado de "produtos com problemas", portanto, coloquialmente a palavra lemons naquele título é melhor representado em português pela palavra "abacaxis"

21 "[...] the widespread availability of firm-specific information concerning publicly listed firms in the economy to those outside the firm. In the framework, we classify information mechanisms into three categories - corporate reporting, private information acquisition, and information dissemination. Corporate reporting involves periodic disclosure of firm-specific information on a voluntary or mandatory basis."

22 "likelihood that firm-specific information that is pertinent to investor pricing decisions is of poor quality" 
grau com que as informações específicas da firma estão incorporadas aos preços. Morck et al.(2000) comparou a sincronicidade dos preços das ações em diversas economias, relacionando aos fatores institucionais. Foram apresentadas evidências empíricas de que os mercados de capitais das economias emergentes são menos atrativos àqueles que operam com base em informações e é menor o grau de incorporação das informações específicas aos preços. Consequentemente, nos mercados emergentes a sincronicidade seria justificadamente maior quando comparado com o que ocorre em ambientes nos quais as informações específicas estão constantemente sendo usadas nas decisões de compra e venda de ações.

Jin e Myers (2006), avaliando o comportamento agregado das ações em vários países perceberam que a falta de transparência corporativa aumenta a sincronicidade. Verificaram que nos países onde as firmas são mais opacas (menos transparentes) aos investidores externos, as ações das empresas apresentam maior sincronicidade e maior frequência de choque (retorno amplo e negativo). Argumentam que se a firma não é completamente transparente, insiders podem capturar os fluxos de caixa que não são percebidos pelos investidores. Isso porque informações que não são divulgadas afetam a divisão do risco assumido pelos gestores entre estes e os investidores que não participam da gestão da empresa. Quando os fluxos de caixa são superiores ao que acreditam os investidores, os insiders podem capturar uma parte desse fluxo de caixa em benefício próprio.

Por outro lado, Grossman e Stiglitz (1980) demonstram que em um ambiente onde a obtenção da informação não está isenta de custos, os preços não podem refletir toda informação disponível pois, nesse caso, aqueles que dispenderam recursos para obtêla não teriam qualquer compensação pelo gasto. Portanto, existe um conflito fundamental entre a eficiência com que as informações são disseminadas pelo mercado e os incentivos para a aquisição delas. Para que se possa lucrar com a informação que foi adquirida com custo é preciso que haja algum nível de ruído no sistema de preços, ou seja, "quando muitos indivíduos tentam obter lucro sobre as informações adquiridas, o equilíbrio é afetado e agrega perfeitamente a informação" (S. Grossman, 1976, p. 574) .

Então as ações com maior eficiência informacional de preços devem ser aquelas: 1) Que recebem a atenção de muitos investidores informados, 2) Com baixo custo para 
obter a informação, 3) Em que os custos de transação são baixos (incluindo as pressões sobre os preços da falta de liquidez) e 4) Que são líquidas. As ações de grandes empresas recebem mais atenção de analistas. Aquelas com alto volume de negociação, com maior a liquidez em bolsa, maior turnover ${ }^{23}$, têm menores custos de transação. Portanto a liquidez em bolsa, porte da empresa, volume de negociação e turnover são indicadores do ambiente informacional da empresa (P. J. Kelly, 2005).

\subsection{Concentração acionária, risco idiossincrático e sincronicidade}

A partir da década de 1990, os temas ligados à governança corporativa ganharam destaque na literatura em finanças quando as empresas, por dificuldades de obterem financiamentos e para aumentar a competitividade, buscaram outras alternativas nos mercados de capitais (Sirqueira, Guimar, \& Toledo, 2007). Governança corporativa surge do reconhecimento da existência de conflitos entre gestores e detentores do capital num ambiente em que o controle da gestão empresarial e propriedade estão separados. O "principal", o qual detém os direitos de propriedade da empresa, delega ao "agente", aquele que gerencia o negócio, o poder de decisão sobre a propriedade. O conflito desponta na medida em que os interesses daquele que gerencia o negócio nem sempre estão alinhados aos do proprietário. Segundo Jensen e Meckling (1976) o relacionamento de agência é um contrato no qual uma ou mais pessoas (principais) nomeiam outra (agente) para tomar decisões em em nome das primeiras.

Grande parte da literatura que trata de governança corporativa e dos efeitos dos conflitos de agência sobre as empresas foi realizado em um contexto anglo-saxão, onde a estrutura de propriedade das empresas é, em geral, pulverizada (Silveira et al., 2004). Entretanto, como observou La Porta et al. (2002), em grande parte do mundo a estrutura de propriedade não é pulverizada e não é rara a presença de um grande acionista controlador ou grupo de acionistas. Morck (2007) esclarece que enquanto grande parte das empresas estadunidenses e britânicas tem suas ações nas mãos de muitos acionistas, a maioria das grandes empresas nos outros lugares são controladas por algumas famílias ricas. É comum observar no Brasil a

${ }^{23}$ Turnover refere-se a relação entre as negociações das ações da empresa no ano em relação ao número de ações outstanding. 
concentração da propriedade em que poucos acionistas detêm uma considerável parcela dos direitos de propriedade da empresa.

A estrutura de incentivos e o ambiente informacional da empresa pode ser alterada pela forma como os direitos de propriedade são partilhados. A separação entre controle e propriedade gera problemas relativos aos incentivos. Os grandes acionistas têm vantagem no monitoramento da gestão em relação aos acionistas pulverizados (Brockman \& Yan, 2009). Por outro lado, o excesso de controle pode gerar um efeito negativo chamado tunneling (transações com benefícios privados) se grandes acionistas extraírem rendimentos privados em detrimento dos acionistas minoritários (Gutiérrez \& Pombo, 2009).

Em relação ao impacto da presença de grandes acionistas (large blockholders) no ambiente informacional, Grossman e Stiglitz (1980) argumentam que a eficiência informacional não pode ser perfeita na presença de ambiente com custos para a aquisição de informação e para arbitragem. Tal situação sugere que a eficiência informacional em relação os preços das ações está inversamente relacionada aos custos de aquisição das informações específicas das empresas. Além disso, os grandes acionistas que detém participação em blocos (blockholder) tendem a arcar com custos mais baixos para obter as informações específicas do que os demais acionistas (Brockman \& Yan, 2009).

$\mathrm{Na}$ literatura internacional o termo Blockholder tem sido usado para designar os acionistas que detém porcentagem igual ou superior a $5 \%$ das ações da empresa (Berry, Paige Fields, \& Wilkins, 2006; R. Bushman, Chen, Engel, \& Smith, 2004; Cremers \& Nair, 2005; Denis, Denis, \& Sarin, 1997; Jung \& Young, 2002; Lin, Ma, \& Xuan, 2011). No Brasil, a Instrução Normativa 358 (2002) da CVM estabelece que os acionistas que atingirem participação que corresponda a 5\% (cinco por cento) das ações devem ser identificados.

O monitoramento por grandes acionistas tem sido objeto de estudo e considerado importante na literatura sobre governança corporativa como forma de mitigar problemas relativos ao conflito de agência (Shleifer \& Vishny, 1986). Maug (1998), ao analisar os incentivos dos grandes acionistas no monitoramento da gestão das empresas de capital aberto, concluiu que as melhorias esperadas nos lucros das 
empresas que são monitoradas são sempre incorporadas no preço das ações e os ganhos são compartilhados com os acionistas que não participam do monitoramento.

Se uma parcela significativa das ações da empresa pertence a um grande acionista, então poucas ações estarão disponíveis no mercado, reduzindo a liquidez das ações dessa empresa. Essa perda de liquidez reduz a expectativa de ganhos do grande acionista com a negociação com base na informação específica e coloca-o sob a seguinte escolha: usar uma grande participação para se comprometer mais com o monitoramento ou diminuir a participação, evitando o comprometimento. Se o mercado for líquido o grande investidor pode recuperar os custos de monitoramento mediante a negociação das ações com base em informações, do contrário haverá pouco incentivo para que ele monitore a gestão.

No Brasil a estrutura de propriedade é caracterizada pela concentração acionária, com arranjos piramidais de propriedade: empresas cujos principais acionistas últimos exercem controle por intermédio de pelo menos uma empresa de capital aberto (Aldrighi, Antonio, \& Postali, 2011, p. 2). A concentração de propriedade está retratada em pesquisas como aquela conduzida por Carvalhal da Silva(2004) em que 225 empresas foram analisadas (correspondendo a $45 \%$ das empresas com capital aberto em dezembro daquele ano). Foi constatado que no ano 2000 a participação acionária direta média do maior acionista era de $51 \%$ do capital total e a média dos cinco maiores acionistas atingia $63 \%$ do capital total naquela amostra. Em 108 empresas ( $48 \%$ da amostra) o controle era exercido por uma família e $91 \%$ dessas empresas estavam em arranjos piramidais. Em outro estudo, Bortolon (2012) analisou 257 empresas em 2006 que tinham capital aberto no Brasil. A participação acionária do maior acionista era, em média, $32,7 \%$ do capital total.

Quanto à disseminação das informações, entende-se os grupos de acionistas têm incentivos para reunir aquelas não isentas de custo de obtenção acerca do desempenho da empresa e dos projetos de investimento, além de outros fundamentos que tenham efeito sobre o valor da empresa. Se a expectativa de resultados não for favorável e a razão for a má qualidade do lucro, o grande acionista lucra com a venda de suas ações, pressionando o preço das ações para baixo. Por outro lado, se esse grande acionista, que adquire a informação, percebe que a causa do fraco desempenho está relacionada a um investimento conveniente para a empresa no 
futuro, ele não terá incentivos para vender sua participação e o preço das ações cairá menos do que na situação anterior. Percebe-se, então, que a estrutura de propriedade impacta o ambiente informacional. Nas duas situações expostas, os acionistas que detém bloco de ações melhoram a eficiência de mercado conduzindo o preço da ação ao seu valor fundamental, interferindo também na atuação do gestor que, assim, estará disposto a realizar investimentos que aumentem o valor da empresa, ainda que com redução dos ganhos no curto prazo (Edmans, 2009).

Edmans(2009) porpõe um modelo em que a atuação dos blockholders aprimorara o valor da firma mesmo sem que haja intervenção na gestão, mas mediante as decisões de negociação da ação, ou seja, decidindo vender ações e dessa forma intervir no preço e direcionando-o ao valor fundamental. Helfin e Shaw (2000) documentram uma relação negativa entre o percentual das ações detidas pelos blockholders e a liquidez no nível da firma, sugerindo uma ligação entre os blockholders e as informações específicas das empresas (Brockman \& Yan, 2009).

Brockman e Yan (2009) investigaram o impacto da concentração de propriedade sobre as informações específicas da empresa incorporadas aos preços. Confirmaram, pelo reflexo observado no aumento do risco idiossincrático, a hipótese de que os blockholders aumentam a quantidade de informações específicas incorporadas aos preços. As evidências empíricas indicaram que os blockholders com incentivos em operar com base em informações específicas transmitem as informações específicas aos preços.

Jin e Myers (2006) argumentam que a limitação no acesso à informação permite que os gestores capturem fluxos de caixa da empresa e assim absorvam parte da variância específica da empresa, gerando sincronicidade dos retornos da ação com o mercado. Nesse caso, acionistas com incentivos no monitoramento devido ao horizonte longo do investimento, como os blockholders, dificultariam as ações dos gestores no sentido de esconder ou se apropriar de parte do fluxo de caixa da empresa. Dessa forma, mais informações específicas seriam incorporadas aos preços, diminuindo a correlação entre os retornos das ações da empresa e o mercado consquentemente aumentando o risco idiossincrático. Tal cenário é compatível com os achados de An e Zhang (2013) em que investidores institucionais dedicados afetam negativamente (positivamente) a sincronicidade (risco idiossincrático). 
Por outro lado a concentração acionária dá oportunidade aos acionistas controladores capturarem fluxos de caixa da empresa em detrimento dos acionistas externos (Claessens, Djankov, Fan, \& Lang, 2002; Fan \& Wong, 2002; R. Morck et al., 2000). Acionistas controladores entrincheirados podem se valer do controle para obter e encobrir vantagens privadas ou para inibir o fluxo de informações. Dessa forma retém informações desfavoráveis ou divulgam seletivamente as informações que os ajuda a camuflar as vantagens obtidas. Ou ainda controlam de maneira oportuna aos seus interesses, o momento em que as informações privadas serão levadas ao mercado. Então a concentração de poder aumentaria a opacidade e afetaria o fluxo de informações específicas aumentando a sincronicidade (F. a. Gul et al., 2010).

\subsection{Opacidade e transparência corporativa}

Para Bushman, Chen, Engel e Smith (2004, p. 168), transparência corporativa referese ao grau de clareza com que a empresa se comunica com o mercado. Bushman, Piotroski e Smith (2004, p. 208) definiram como a disponibilização de informações específicas das empresas de capital aberto a terceiros.

Nas pesquisas científicas os termos disclosure e transparência têm sido associados à qualidade das informações, contábeis ou não, divulgadas nos informativos obrigatórios. No Brasil, a utilização do termo disclosure como qualidade das informações contábeis obrigatórias divulgadas pelas empresas e sinônimo de transparência corporativa pode ser observada em Alencar (2007), Boscov (2011), Dantas (2008), Lima (2007), Malacrida e Yamamoto (2006) entre outros. Como exemplo está o prêmio ANEFAC - FIPECAFI - SERASA EXPERIAN (Troféu Transparência) ${ }^{24}$, concedido às empresas em que as demonstrações contábeis obrigatórias são avaliadas segundo critérios técnicos acerca das práticas de transparência nas informações contábeis, avaliadas por estudantes de mestrado em ciências contábeis da FEA-USP.

Neste estudo o termo "Opacidade" refere-se à falta de transparência corporativa, ou ainda a "não-transparência". Por sua vez, a expressão transparência corporativa (ou simplesmente "transparência") será usada para designar o grau de clareza com que

24 Prêmio ANEFAC - FIPECAFI - SERASA EXPERIAN (Troféu Transparência) http://www.anefac.com.br/Pages/page. aspx?tema $=4 \&$ id $=29$ 
as informações específicas da empresa são comunicadas pelos representantes dela (como os gestores) aos participantes do mercado, seja por meio dos informativos obrigatórios, seja de maneira voluntária como a divulgação de projeções de resultados

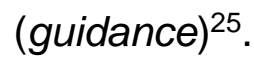

Vale lembrar que, conforme estabelece a Instrução CVM № 480/09, entre as informações obrigatórias normatizadas pelo órgão competente que incluem os relatórios financeiros estão as informações anuais, o formulário cadastral, o formulário de referência, as projeções e estimativas além das informações eventuais.

Observa-se, portanto, que a comunicação entre empresa e mercado se dá por meio de vários instrumentos além das demonstrações contábeis padronizadas e obrigatórias. Entretanto, a qualidade das informações divulgadas ao mercado (nível de disclosure) nos demonstrativos contábeis obrigatórios tem sido de maneira recorrente usada como medida do grau de transparência na comunicação entre gestores e investidores.

Além disso, informações sobre remuneração de executivos, modificações no corpo diretivo, doença ou acidente envolvendo gestores e entrada de um novo concorrente no mercado são exemplos de informações específicas das empresas passíveis de serem precificadas e incorporadas aos preços e cuja divulgação pode acontecer no momento da ocorrência do evento, desvinculada da data da publicação das informações contábeis obrigatórias. Nesses casos, a forma como a empresa se dirige ao mercado, esclarecendo sobre as implicações do fato e o impacto sobre o desempenho futuro, reflete o grau de transparência dos gestores em relação aos fatos que podem afetar a expectativa de rentabilidade futura da empresa.

Já, os relatórios contábil-financeiros obrigatórios são divulgados várias semanas após o encerramento do período em que os fatos ocorreram. No entanto, tais informações têm um adicional de credibilidade pelo fato de serem auditadas. Já as notícias publicadas sem o crivo da auditoria poderiam representar a interpretação mais conveniente dos fatos e de suas implicações sobre a lucratividade do negócio.

\footnotetext{
${ }^{25}$ Forma de comunicação prevista e normatizada pela Comissão de Valores Mobiliários, por meio da Instrução CVM no 480/09, artigo 20 que prevê que a divulgação é facultativa e pelo OFÍCIOCIRCULAR/CVM/SEP/N001/2010, ou ainda por qualquer outro meio.
} 
Desta feita, a interpretação dos fatos importantes que impactaram as atividades da empresa ao longo do período abrangido pelos relatórios financeiros obrigatórios será validada, ou não, pela auditoria antes da divulgação obrigatória. Portanto, o mercado poderá avaliar se as informações divulgadas tempestivamente são compatíveis com a versão auditada e o preço da ação poderá ser ajustado ou não.

Se na ocasião da divulgação dos resultados todas as informações lá constantes já tiverem sido incorporadas aos preços, então a publicação dos relatórios não deverá alterar o patamar de preços da empresa, sob a hipótese da eficiência de mercado. Dessa forma, a flutuação de preços após o anúncio de resultados (conhecido na literatura por post earnings announcement drift - PEAD) ${ }^{26}$, tenderá a zero se, nos relatórios divulgados, nenhuma informação nova for divulgada ao mercado. Nesse caso, os relatórios contábeis terão um papel de confirmar as informações divulgadas anteriormente. Desse contexto deriva a hipótese do papel confirmatório dos relatórios financeiros obrigatórios, tratada na literatura contábil em pesquisas como aquelas conduzidas por: Arya, Glover, Mittendorf e Zhang (2004); Ball, Jayaraman e Shivakumar (2012); Beniluz (2005); Gigler e Hemmer (1998).

Suportado na hipótese do papel confirmatório dos relatórios financeiros obrigatórios, o PEAD pode ser considerado um indicador de opacidade (não-transparência) das informações transmitidas ao mercado referentes às atividades da empresa que afetam a expectativa desempenho futuro. Então, no caso de não haver surpresa quando da divulgação dos relatórios obrigatórios, depreende-se que as informações que afetam a percepção sobre o desempenho futuro já tenham sido divulgadas ao mercado por outros meios.

\subsection{Accruals discricionários, transparência e opacidade}

Enquanto transparência corresponde ao grau de clareza com que as informações são transmitidas ao mercado pelos gestores, opacidade refere-se ao distanciamento da transparência. Evidências empíricas indicam que o gerenciamento dos accruals discricionários ${ }^{27}$ obscurecem as informações sobre fundamentos divulgadas pelos

\footnotetext{
26 Relatado por Bernard e Thomas (1989)

27 "A diferença entre o lucro líquido e o fluxo de caixa operacional líquido é conhecida como accruals (acumulações). Portanto, accruals seriam todas aquelas contas de resultado que entraram no cômputo do lucro, mas que não implicam em necessária movimentação de disponibilidades."(Martinez, 1995, p. 8)
} 
gestores (Sloan, 1996) e, por essa razão pode ser considerado como uma medida do grau de opacidade.

$\mathrm{Na}$ contabilização pelo regime de competência o lucro é uma medida da eficiência econômica, e um indicativo do desempenho da empresa e uma estimativa dos fluxos de caixa futuro associados a eventos econômicos (Dechow, 1994). Os fatos contábeis são reconhecidos no momento da ocorrência, independente das efetivas entradas ou saídas de caixa. Os accruals relacionados ao capital de giro ajustam o fluxo de caixa operacional resultando em um lucro com menos ruído do que o fluxo de caixa (Ball, Jayaraman, \& Shivakumar, 2006).

O principal objetivo da contabilidade pelo regime de competência é ajudar os investidores a avaliar o desempenho econômico num intervalo de tempo com base nos princípios contábeis, de tal forma que o lucro demonstrado confere informação com maior qualidade sobre o desempenho da empresa do que os fluxos de caixa (Dechow \& Skinner, 2000). Contudo, a contabilidade pelo regime de competência com base nos princípios contábeis está sujeita a escolhas que dependem de julgamento por parte dos gestores. As escolhas contábeis podem ser motivadas por interesses pessoais se, por exemplo, a remuneração variável for condicionada ao comportamento dos preços das ações (Fields, Lys, \& Vincent, 2001).

Sloan (1996) documentou a anomalia dos accruals, a qual se refere à observação empírica de que os accruals estão negativamente correlacionados com os retornos anormais ao longo do ano seguinte. Tal situação sugere que o mercado não avalia corretamente o fato de a parcela dos lucros relacionadas aos accruals ser menos persistente do que o componente relativo ao fluxo de caixa. Aparentemente o mercado reage de maneira exagerada ao resultado que contém grande componente de accruals. Porém, segundo Sloan (1996), essa reação exagerada é revertida quando da divulgação de resultados no ano seguinte, sugerindo que o mercado aprende que o lucro do período anterior não era sustentável. Existem inúmeras situações que permitem o julgamento dos gestores e, como consequência, podem gerar vários impactos diferentes sobre o lucro, dependendo da forma como são interpretadas. Por exemplo, a escolha sobre o tempo de vida econômica de um bem afeta o período da depreciação e a despesa correspondente, assim como o reconhecimento ou não de prováveis perdas ou ainda as decisões relativas aos testes de impairement (Healy \& 
Wahlen, 1999). Os gestores também exercem seu poder discricionário na escolha entre leasing financeiro ou operacional ou quando alteram o nível de produção com o objetivo de reduzir os custos fixos alocados aos produtos fabricados. Dechow e Skinner (2000) detalham diferentes tipos de escolhas que podem ser realizadas pelos gestores entre as quais estão aquelas consideradas agressivas embora aceitáveis, além das práticas fraudulentas. Ressaltam ainda a importância de distinguir fraude de gerenciamento de resultados, como também diferenciar o legítimo exercício da discricionariedade contábil. Ou seja, o excessivo reconhecimento das provisões ou supervalorização em projetos de pesquisa e desenvolvimento podem ser considerados práticas conservadoras. Subestimar provisões de recebíveis ruins pode ser caracterizado como contabilidade agressiva enquanto o reconhecimento de vendas antes de serem realizáveis constitui em fraude contábil.

A expressão "gerenciamento de resultados" deve ser aplicada nos casos em que as escolhas contábeis legítimas são usadas para mascarar ou obscurecer o desempenho real econômico, atendendo a objetivos que não sejam a maximização do valor para o acionista. Gerenciamento de resultados refere-se às escolhas contábeis que, de maneira proposital, afetam as informações contábeis divulgadas com intuito de obter ganhos (Schipper, 1989). Ocorre quando, nos relatórios financeiros, os gestores usam julgamento na estruturação de operações para induzir impressões sobre o desempenho econômico da empresa (Healy \& Wahlen, 1999, p. 368).

Kasznik (1999) encontrou evidências de que os gestores se valem de accruals discricionários para divulgar resultados melhores quando o lucro, de outra maneira, seria menor do que as projeções divulgadas. Nesse sentido, Sloan (1996) observou que o gerenciamento de accruals obscurece algumas informações sobre os fundamentos da empresa.

Os estudos sobre gerenciamento de resultados contábeis "examinam se os gestores agem como se acreditassem que os usuários dos dados dos relatórios financeiros podem ser induzidos a erro de interpretação dos lucros contábeis divulgados como equivalente a lucratividade econômica"28 (Fields et al., 2001, p. 279).

28 "whether managers act as if they believe users of financial reporting data can be misled into interpreting reported accounting earnings as equivalent to economic profitability" 
Se os lucros divulgados são uma estimativa do desempenho econômico futuro da empresa, a acurácia dessa informação depende da qualidade dos accruals, usados para estimar o fluxo de caixa líquido futuro, que estão associados aos eventos econômicos passados. Contudo, os lucros e os accruals são estimativas produzidas pelos gestores e validadas pelos auditores (Hutton, Marcus, \& Tehranian, 2009). Sendo os accruals estimativas produzidas pelos gestores, eles estão sujeitos ao gerenciamento das escolhas contábeis. Existem situações em que as escolhas contábeis são resultado de manipulação dos gestores gerando distorções na medida do lucro como estimativa dos fluxos de caixa líquidos futuros.

Entre os modelos descritos na literatura para avaliar o processo de geração dos accruals discricionários destacam-se:

\subsubsection{Modelo de Jones}

Jones (1991) propôs um modelo que para controlar os efeitos das mudanças das circunstâncias econômicas sobre os accruals não discricionários e assume que as receitas são não-discricionárias (Dechow, Sloan, \& Sweeney, 1995). Pelo modelo, o accrual não discricionário em cada ano é dado por:

$$
N D A_{\tau}=\alpha_{1}\left(\frac{1}{A_{\tau-1}}\right)+\alpha_{2}\left(\frac{\Delta R E V_{\tau}}{A_{\tau-1}}\right)+\alpha_{3}\left(\frac{P P E_{\tau}}{A_{\tau-1}}\right)
$$

Onde

$\triangle R E V_{\tau}=$ Receitas no ano $\mathrm{T}$ menos receitas no ano $\mathrm{T}-1$;

$P P E_{\tau}=$ Imobilizado bruto no ano $\mathrm{T}$;

$A_{\tau-1}=$ Total dos ativos em $\mathrm{T}-1$;

$\alpha_{1} ; \alpha_{2} ; \alpha_{3}=$ parâmetros específicos estimados para cada ano pela regressão:

$$
\begin{gathered}
\frac{T A_{\tau}}{A_{\tau-1}}=a_{1}\left(\frac{1}{A_{\tau-1}}\right)+a_{2}\left(\frac{\Delta R E V_{\tau}}{A_{\tau-1}}\right)+a_{3}\left(\frac{P P E_{\tau}}{A_{\tau-1}}\right)+\varepsilon_{t} \\
T A_{\tau}=\Delta A C_{\tau}-\Delta \text { Caixa }_{\tau}-\Delta P C_{\tau}-\text { DespDepr }_{\tau}
\end{gathered}
$$

Onde $\Delta$ é computado entre o período т е т-1

$\mathrm{AC}=$ Ativo Circulante 
$P C=$ Passivo Circulante

$\operatorname{DespDepr}_{\tau}=$ Despesa de Depreciação

$\varepsilon_{t}=$ termo de erro

\subsubsection{Modelo de Jones Modificado}

Dechow, Sloan e Sweeney (1995) propõe uma modificação no modelo de Jones em que a variação nas receitas é ajustada pela variação em recebíveis, de tal forma que os accruals não-discricionários são medidos pela equação:

$$
N D A_{\tau}=\alpha_{1}\left(\frac{1}{A_{\tau-1}}\right)+\alpha_{2}\left(\frac{\Delta R E V_{\tau}-\Delta R E C_{\tau}}{A_{\tau-1}}\right)+\alpha_{3}\left(\frac{P P E_{\tau}}{A_{\tau-1}}\right)
$$

Onde

$\Delta R E C_{\tau}=$ Recebíveis em $\mathrm{T}$ diminuído dos recebíveis em $\mathrm{T}-1$

Entretanto os parâmetros estimados $\alpha_{1} ; \alpha_{2} ; \alpha_{3}$ são obtidos com base no modelo de Jones.

\subsubsection{Jones Modificado combinado com desempenho}

Kothari, Leone, e Wasley (2005) propuseram a inclusão do Retorno sobre Investimentos para controlar por semelhança no desempenho, de tal forma que o modelo passa a ser descrito pela equação:

$$
N D A_{\tau}=\alpha_{1}\left(\frac{1}{A_{\tau-1}}\right)+\alpha_{2}\left(\frac{\Delta R E V_{\tau}-\Delta R E C_{\tau}}{A_{\tau-1}}\right)+\alpha_{3}\left(\frac{P P E_{\tau}}{A_{\tau-1}}\right)+\alpha_{3}\left(\frac{R O A_{\tau}}{A_{\tau-1}}\right)
$$

Onde

$R O A_{\tau}=$ Retorno sobre ativos, obtido pela divisão do lucro líquido em t pelo ativo total em T.

Em estudos como aqueles conduzidos por Hutton et al. (2009); Lang \& Maffett (2011); Lang et al.(2011), An e Zhang (An \& Zhang, 2013), Chen et al.(2012) o gerenciamento 
de resultados ${ }^{29}$ (ou gerenciamento dos accruals discricionários) foi usado como medida de opacidade da empresa em relação ao mercado. Hutton et al.(2009) encontraram evidências de que o gerenciamento de resultados está positivamente relacionado com a medida de sincronicidade.

\subsection{Opacidade e o post earning announcement drift}

Ball e Brown (1968) observaram que os preços das ações reagiam aos resultados divulgados nos relatórios anuais obrigatórios de tal forma que, em média, os retornos anormais estimados eram positivos na presença de "boas notícias" e negativos em presença de "más notícias". Tal comportamento foi verificado em inúmeras pesquisas mesmo nos anúncios trimestrais de resultado (Sudipta Basu, Markov, \& Shivakumar, 2009; Bernard \& Thomas, 1989, 1990; P. Brown \& Kennelly, 1972; S. S. Cao \& Narayanamoorthy, 2012; Danbolt, Hirst, \& Jones, 2011; J. Francis, Lafond, Olsson, \& Schipper, 2007; C. P. Jones \& Litzenberger, 1970; Mendenhall, 2004; Sadka, 2006).

As explicações para tal comportamento, segundo Bernard \& Thomas (1989) são subdivididas em duas categorias:

1) A resposta dos preços das ações às informações divulgadas se dá de maneira tardia em razão dos operadores não conseguirem assimilar completamente a informação nova disponibilizada ou porque determinados custos (como custos de transação, de oportunidade ou de monitoramento de estratégias de negociação) são superiores aos ganhos na exploração imediata da informação ou

2) O modelo usado para medir os retornos anormais (CAPM) é incompleto, gerando estimativas incorretas e os pesquisadores têm dificuldade em ajustar o retorno observado ao risco. O retorno anormal é a compensação pelo risco assumido o qual é precificado, mas não capturado pelo modelo de precificação de ativos - CAPM.

Pesquisadores têm se preocupado com a aparente demora dos preços das ações se ajustarem às informações contidas nas divulgações de resultados. A hipótese formulada por Jones \& Litzenberger(1970) é a de que as surpresas em relação aos

29 "earnings management" 
lucros causariam ajustamento gradual nos preços e não imediato. Isso seria resultado da disseminação gradual para o público investidor, das percepções dos profissionais de mercado acerca das implicações das "surpresas" divulgadas nos relatórios obrigatórios, contrariando a visão de um mercado eficiente na forma semiforte.

A reação dos preços das ações após os anúncios dos lucros (fenômeno conhecido na literatura como Post-Earnings-Announcement Drift - PEAD) refere-se aos retornos anormais relacionados aos sinais contidos nas informações públicas que, aparentemente, são subutilizadas pelos participantes do mercado. Está relacionado com o aprendizado dos investidores que racionalmente ponderam com menor peso os investimentos em que os sinais são imprecisos, até que a incerteza em relação à informação seja resolvida (J. Francis et al., 2007, p. 408). Esse comportamento do mercado não é compatível com a teoria dos mercados eficientes na medida em que investidores podem obter retornos anormais previsíveis a partir de uma informação obtida e processada sem custo obtendo, assim, lucro econômico. Portanto tal situação refere-se a uma anomalia (Ball, 1992, p. 321)

Estudos como aquale condizido por Jegadeesh \& Livnat (2006) relatam que o fenômeno PEAD relaciona-se não somente ao comportamento do lucro, mas a surpresas relativas às receitas, indicando que existe uma questão relacionada à qualidade das informações disponibilizadas aos participantes do mercado e a anomalia.

A qualidade da informação também permeia pesquisas que relacionam incerteza em relação à informação (information uncertanty) e o PEAD. Zhang (2006) propõe um modelo em que a incerteza informacional refere-se à ambiguidade das implicações das novas informações sobre o valor da firma e que decorre de duas fontes: a volatilidade subjacente aos fundamentos e outra parcela que reflete a falta de qualidade da informação. Como resultado, Zhang (2006) observou que a incerteza em relação à informação afeta os retornos esperados após a divulgação de informações específicas.

Francis et al. (2007, p. 429) também estudaram o papel da incerteza em relação à informação e o PEAD, relacionando-o às previsões derivadas de modelos de aprendizagem em que os investidores racionalmente colocam menos peso sobre os 
sinais de ganhos inesperados decorrentes de elevada incerteza sobre informações. Como proxy de incerteza em relação à informação os autores usaram uma medida derivada da qualidade dos accruals.

Os estudos sobre a reação dos preços das ações após os anúncios dos lucros indicam que as incertezas dos investidores em relação às informações estão associadas aos retornos anormais em torno das datas das publicações dos resultados. Dessa forma, é razoável supor que a transparência na comunicação entre empresa e mercado possa reduzir a ambiguidade das implicações das novas informações sobre o valor da firma, impactando na dimensão do PEAD. Nesse contexto, a magnitude da reação dos preços das ações aos anúncios dos lucros pode ser considerada um sinal do grau da opacidade da empresa em relação ao mercado.

\subsection{Evidências}

Desde que Roll (1988) propôs que eventos específicos das empresas poderiam ser uma explicação plausível para aquelas variações nos preços das ações que não estão correlacionadas aos fatores sistemáticos, inúmeros estudos têm procurado validar ou refutar tal suposição.

Mas, a medida de risco idiossincrático construída a partir do coeficiente de determinação $\mathrm{R}^{2}$ passou a ser usada como proxy do grau de incorporação de informações específicas nos preços das ações a partir do estudo de Morck et al (2000), que relacionou a volatilidade dos retornos específicos (ou seja, o risco idiossincrático) à eficiência funcional dos mercados de capitais.

O Quadro 1, a seguir, sintetiza os avanços recentes das pesquisas que buscam compreender o significado econômico e identificar os fatores que afetam o risco idiossincrático (ou complementarmente a sincronicidade) no período compreendido entre 2000 e 2014.

De maneira geral, observa-se que embora na literatura muitos pesquisadores utilizem a medida de risco idiossincrático ou seu complemento sincronicidade como indicador eficiência informacional dos preços das ações, a validade dessa medida bem como a forma pela qual as informações são incorporadas aos preços ainda não estão perfeitamente esclarecidas. Também não ficou comprovado que a volatilidade dos 
retornos idiossincráticos corresponde às informações específicas incorporadas aos preços como decorrência da clareza na comunicação entre empresa e mercado.

Quadro 1: Quadro resumo das principais evidências sobre a relação entre risco idiossincrático/sincronicidade e o ambiente informacional

\begin{tabular}{|c|c|c|c|c|c|}
\hline Ano & Autores & $\begin{array}{l}\text { Variável } \\
\text { dependente }\end{array}$ & \begin{tabular}{|l} 
Variáveis \\
Explicativas
\end{tabular} & $\begin{array}{l}\text { Período, } \\
\text { Ambiente }\end{array}$ & Principais achados \\
\hline 2000 & $\begin{array}{l}\text { Morck, } \\
\text { Randall; } \\
\text { Yeung, } \\
\text { Bernard; } \\
\text { Yu, Wayne }\end{array}$ & $\begin{array}{l}\text { Média } \\
\text { ponderada } \\
\text { da } \\
\text { sincronici- } \\
\text { dade das } \\
\text { ações de } \\
\text { cada país } \\
\text { analisado: } \\
\text { Sincronici- } \\
\text { dade } \\
\ln \left(\frac{R^{2}}{1-R^{2}}\right)\end{array}$ & $\begin{array}{l}\text { Número de } \\
\text { ações listadas; } \\
\text { PIB per capta; } \\
\text { tamanho do } \\
\text { mercado; } \\
\text { tamanho do país } \\
\left(\mathrm{Km}^{2}\right) ; \\
\text { diversificação } \\
\text { econômica e } \\
\text { gerencial; índice } \\
\text { de bom governo }\end{array}$ & $\begin{array}{l}1995 \\
\text { Mercados } \\
\text { de vários } \\
\text { países }\end{array}$ & $\begin{array}{l}\text { Os autores encontraram } \\
\text { evidências empíricas sugerindo } \\
\text { que os retornos das ações são } \\
\text { mais sincronizados em } \\
\text { economias emergentes do que } \\
\text { em economias desenvolvidas. }\end{array}$ \\
\hline 2000 & $\begin{array}{l}\text { Wurgler, } \\
\text { Jeffrey }\end{array}$ & $\begin{array}{l}\text { Eficiência na } \\
\text { alocação de } \\
\text { capital no } \\
\text { país, } \\
\text { medido } \\
\text { como } \\
\text { elasticidade } \\
\text { do valor } \\
\text { agregado do } \\
\text { investimento } \\
\text { industrial }\end{array}$ & $\begin{array}{l}\text { Sincronicidade; } \\
\text { Desenvolvimento } \\
\text { financeiro; } \\
\text { tamanho do } \\
\text { mercado; fração } \\
\text { do resultado da } \\
\text { economia devido } \\
\text { a empresas } \\
\text { pertencentes ao } \\
\text { governo; índice } \\
\text { de efetividade } \\
\text { dos direitos dos } \\
\text { investidores. }\end{array}$ & $\begin{array}{l}\text { 1963-1995 } \\
\text { Mercados } \\
\text { de } \\
\text { diversos } \\
\text { países }\end{array}$ & $\begin{array}{l}\text { A eficiência da alocação de } \\
\text { capital está negativamente } \\
\text { correlacionada com o grau de } \\
\text { participação do Estado na } \\
\text { economia, positivamente } \\
\text { correlacionada com a } \\
\text { quantidade de informações } \\
\text { específicas sobre a empresa no } \\
\text { mercado doméstico e } \\
\text { positivamente correlacionada } \\
\text { com a proteção jurídica dos } \\
\text { investidores minoritários. }\end{array}$ \\
\hline 2003 & \begin{tabular}{|l} 
Durnev, \\
Artyom; \\
Morck, \\
Randall; \\
Yeung, \\
Bernard; \\
Zarowin, \\
Paul \\
\end{tabular} & $\begin{array}{l}\text { Risco } \\
\text { idiossincráti- } \\
\text { co } \\
\ln \left(\frac{1-R^{2}}{R^{2}}\right)\end{array}$ & $\begin{array}{l}\text { Coeficiente de } \\
\text { resposta aos } \\
\text { lucros futuros } \\
\text { (FERC) }\end{array}$ & $\begin{array}{l}1983-1995 \\
\text { Mercado } \\
\text { estaduni- } \\
\text { dense }\end{array}$ & $\begin{array}{l}\text { Menor sincronicidade (maior } \\
\text { volatilidade idiossincrática) está } \\
\text { associada a preços de ações } \\
\text { mais informativos }\end{array}$ \\
\hline 2004 & $\begin{array}{l}\text { Durnev, } \\
\text { Art;Morck, } \\
\text { Randall;Yeu } \\
\text { ng, Bernard }\end{array}$ & \begin{tabular}{|l|} 
Qualidade \\
do \\
orçamento \\
de capital (a \\
partir do Q \\
de Tobin)
\end{tabular} & $\begin{array}{l}\text { Variância do } \\
\text { retorno da ação; } \\
\text { risco } \\
\text { idiossincrático; } \\
\quad \ln \left(\frac{1-R^{2}}{R^{2}}\right)\end{array}$ & $\begin{array}{l}1983-1992 \\
\text { Mercado } \\
\text { estaduni- } \\
\text { dense }\end{array}$ & $\begin{array}{l}\text { O orçamento de capital está } \\
\text { mais alinhado com a } \\
\text { maximização do valor de } \\
\text { mercado quando a variação do } \\
\text { retorno específico é maior } \\
\text { (maior risco idiossincrático). }\end{array}$ \\
\hline
\end{tabular}


Quadro 1 (cont.)

\begin{tabular}{|c|c|c|c|c|c|}
\hline Ano & Autores & $\begin{array}{l}\text { Variável } \\
\text { dependente }\end{array}$ & $\begin{array}{l}\text { Variáveis } \\
\text { Explicativas }\end{array}$ & $\begin{array}{l}\text { Período, } \\
\text { Ambiente }\end{array}$ & Principais achados \\
\hline 2006 & $\begin{array}{l}\text { Jin, L; } \\
\text { Myers, S }\end{array}$ & $\begin{array}{l}\text { Sincronici- } \\
\text { dade } \\
\ln \left(\frac{R^{2}}{1-R^{2}}\right)\end{array}$ & $\begin{array}{l}\text { Frequência das } \\
\text { rupturas } \\
\text { (retornos } \\
\text { grandes e } \\
\text { negativos - nível } \\
\text { país) e outras } \\
\text { variáveis } \\
\text { representativas } \\
\text { do ambiente } \\
\text { econômico }\end{array}$ & $\begin{array}{l}1990-2001 \\
\text { Diversos } \\
\text { mercados } \\
\text { inclusive o } \\
\text { mercado } \\
\text { estaduni- } \\
\text { dense }\end{array}$ & $\begin{array}{l}\text { Os direitos de controle e } \\
\text { informação afetam a divisão de } \\
\text { risco entre os gestores e } \\
\text { investidores. A falta de } \\
\text { transparência aumenta } \mathrm{R}^{2} \text {. } \\
\text { Empresas opacas com alta } \\
\text { sincronicidade são mais } \\
\text { propensas a apresentarem } \\
\text { grandes retornos negativos. } \\
\text { Encontradas relações positivas } \\
\text { entre } \mathrm{R}^{2} \text { e diversas medidas de } \\
\text { opacidade. }\end{array}$ \\
\hline 2007 & $\begin{array}{l}\text { Chen, Qi; } \\
\text { Goldstein } \\
\text {,Itai;Jiang, } \\
\text { W. }\end{array}$ & $\begin{array}{l}\text { Investimento } \\
\text { em relação } \\
\text { ao ativo total } \\
\text { no início do } \\
\text { ano }\end{array}$ & $\begin{array}{l}\text { Risco } \\
\text { idiossincrático } \\
1-R^{2}\end{array}$ & $\begin{array}{l}\text { 1981-2001 } \\
\text { Mercado } \\
\text { estaduni- } \\
\text { dense }\end{array}$ & $\begin{array}{l}\text { Forte relação positiva entre o } \\
\text { montante de informação } \\
\text { privada nos preços das ações } \\
\text { (e que uma das proxies foi a } \\
\text { não-sincronicidade) e a } \\
\text { sensibilidade do investimento } \\
\text { ao preço. }\end{array}$ \\
\hline 2007 & $\begin{array}{l}\text { Irvine, P. } \\
\text { J;Pontiff, } \\
\text { Jeffrey } \\
\text { usa } \quad \text { o } \\
\text { modelo de } \\
\text { Campbel, } \\
\text { por isso não } \\
\text { entrará na } \\
\text { minha tabela }\end{array}$ & $\begin{array}{l}\text { Volatilidade } \\
\text { idiossincrá- } \\
\text { tica } \\
\text { proposta por } \\
\text { Campbel } \\
\text { (2001). Não } \\
\text { utiliza a } \\
\text { variável } \\
\text { derivada do } \\
\mathrm{R}^{2} \text {. }\end{array}$ & $\begin{array}{l}\text { Série de tempo } \\
\text { da volatilidade } \\
\text { idiossincrática } \\
\text { agregada; } \\
\text { competição no } \\
\text { mercado; } \\
\text { desregulamenta- } \\
\text { ção de setores; } \\
\text { competitividade } \\
\text { internacional }\end{array}$ & $\begin{array}{l}\text { 1964-2001 } \\
\text { Mercado } \\
\text { estaduni- } \\
\text { dense }\end{array}$ & $\begin{array}{l}\text { O aumento da volatilidade } \\
\text { idiossincrática está relacionado } \\
\text { ao aumento da competitividade } \\
\text { da economia. Países com } \\
\text { maior crescimento na } \\
\text { volatilidade idiossincrática } \\
\text { tendem a ser economias mais } \\
\text { competitivas e passam por } \\
\text { maiores mudanças nas } \\
\text { inovações tecnológicas. }\end{array}$ \\
\hline 2007 & $\begin{array}{l}\text { Fernandes, } \\
\text { N.;Ferreira, } \\
\text { M. A. }\end{array}$ & $\begin{array}{l}\text { Risco } \\
\text { idiossincráti- } \\
\text { co } \\
\ln \left(\frac{1-R^{2}}{R^{2}}\right)\end{array}$ & $\begin{array}{l}\text { Índice de boa } \\
\text { governança } \\
\text { (nível país); ano } \\
\text { do primeiro caso } \\
\text { de aplicação da } \\
\text { lei de } \\
\text { informações } \\
\text { privilegiadas no } \\
\text { país; PIB ; } \\
\text { concentração } \\
\text { industrial; } \\
\text { número de } \\
\text { empresas } \\
\text { listadas; nível de } \\
\text { transparência da } \\
\text { contabilidade do } \\
\text { país }\end{array}$ & $\begin{array}{l}1980-2003 \\
\text { Mercados } \\
\text { de } 48 \\
\text { países dos } \\
\text { quais } 24 \\
\text { emergen- } \\
\text { tes }\end{array}$ & $\begin{array}{l}\text { Aplicação da lei sobre } \\
\text { informações privilegiadas é } \\
\text { associada com maior variação } \\
\text { de retorno específico das } \\
\text { empresas nos mercados } \\
\text { desenvolvidos; o inverso nos } \\
\text { mercados emergentes. A } \\
\text { aplicação da lei de insider } \\
\text { trading nos mercados } \\
\text { emergentes tem um efeito } \\
\text { insignificante sobre a variação } \\
\text { de retorno específico das } \\
\text { empresas. }\end{array}$ \\
\hline
\end{tabular}


Quadro 1 (cont.)

\begin{tabular}{|c|c|c|c|c|c|}
\hline Ano & Autores & $\begin{array}{l}\text { Variável } \\
\text { dependente }\end{array}$ & $\begin{array}{l}\text { Variáveis } \\
\text { Explicativas }\end{array}$ & $\begin{array}{l}\text { Período, } \\
\text { Ambiente }\end{array}$ & Principais achados \\
\hline 2009 & $\begin{array}{l}\text { Hutton, Amy } \\
\text { P.; } \\
\text { Marcus, } \\
\text { Alan J.; } \\
\text { Tehranian, } \\
\text { Hassan }\end{array}$ & $\begin{array}{l}\text { Risco } \\
\text { idiossincrá- } \\
\text { tico } \\
\ln \left(\frac{1-R^{2}}{R^{2}}\right)\end{array}$ & $\begin{array}{l}\text { Opacidade: } \\
\text { soma do valor } \\
\text { absoluto dos } \\
\text { accruals } \\
\text { discricionários } \\
\text { dos } 3 \text { anos } \\
\text { anteriores } \\
\text { Tamanho da } \\
\text { empresa } \\
\text { RSPL; } \\
\text { Market-to-book } \\
\text { Alavancagem } \\
\end{array}$ & $\begin{array}{l}1991-2005 \\
\text { Mercado } \\
\text { estaduni- } \\
\text { dense }\end{array}$ & $\begin{array}{l}\text { Encontrou relação positiva } \\
\text { entre sincronicidade e } \\
\text { opacidade; positiva com } \\
\text { tamanho e Retorno sobre o } \\
\text { patrimônio líquido }\end{array}$ \\
\hline 2009 & $\begin{array}{l}\text { Brockman, } \\
\text { Paul;Yan, } \\
\text { Xuemin } \\
\text { (Sterling) }\end{array}$ & $\begin{array}{l}\text { Sincronici- } \\
\text { dade } \\
\ln \left(\frac{R^{2}}{1-R^{2}}\right)\end{array}$ & $\begin{array}{l}\text { Variáveis que } \\
\text { refletem os } \\
\text { blocos de } \\
\text { controle } \\
\text { acionário e } \\
\text { variáveis de } \\
\text { controle }\end{array}$ & $\begin{array}{l}1996-2001 \\
\text { Mercado } \\
\text { estaduni- } \\
\text { dense }\end{array}$ & $\begin{array}{l}\text { As evidências empíricas } \\
\text { confirmam a hipótese de que a } \\
\text { vantagem infomacional dos } \\
\text { blockholders tem efeito sobre a } \\
\text { volatilidade idiossincrática. A } \\
\text { presença de grandes acionistas } \\
\text { controladores reduz a } \\
\text { sincronicidade. }\end{array}$ \\
\hline 2010 & $\begin{array}{l}\text { Gul, } \\
\text { Ferdinand } \\
\text { a.;Kim, } \\
\text { Jeong-Bon; } \\
\text { Qiu, Annie } \\
\text { a. }\end{array}$ & $\begin{array}{l}\text { Sincronici- } \\
\text { dade } \\
\ln \left(\frac{R^{2}}{1-R^{2}}\right)\end{array}$ & $\begin{array}{l}\text { Percentual das } \\
\text { ações possuídas } \\
\text { pelo maior } \\
\text { acionista no } \\
\text { início do período } \\
\text { e variáveis de } \\
\text { controle entre as } \\
\text { quais tamanho, } \\
\text { volume, } \\
\text { alavancagem, } \\
\text { Market to Book }\end{array}$ & $\begin{array}{l}1996-2003 \\
\text { Mercado } \\
\text { chinês }\end{array}$ & $\begin{array}{l}\text { Encontradas evidências de que } \\
\text { a sincronicidade é uma função } \\
\text { côncava da participação do } \\
\text { maior acionista com o seu } \\
\text { máximo em um valor } \\
\text { aproximado de } 50 \% \text { nível. A } \\
\text { sincronicidade é maior quando } \\
\text { o maior acionista é o governo. } \\
\text { A participação estrangeira no } \\
\text { capital e qualidade da auditoria } \\
\text { são inversamente associados } \\
\text { com a sincronicidade. }\end{array}$ \\
\hline 2010 & $\begin{array}{l}\text { Dasgupta, } \\
\text { Sudipto; } \\
\text { Gan, Jie; } \\
\text { Gao, } \\
\text { NingXinga, } \\
\text { Xuejing }\end{array}$ & $\begin{array}{l}\text { Sincronici- } \\
\text { dade } \\
\ln \left(\frac{R^{2}}{1-R^{2}}\right)\end{array}$ & $\begin{array}{l}\text { Número de anos } \\
\text { que antecederam } \\
\text { a emissão de } \\
\text { ADR's; Idade da } \\
\text { empresa; } \\
\text { volatilidade; beta } \\
\text { do país, beta } \\
\text { estadunidense; } \\
\text { tamanho; } \\
\text { alavancagem; } \\
\text { lucratividade } \\
\text { (retorno sobre } \\
\text { investimentos); } \\
\text { Market to Book }\end{array}$ & $\begin{array}{l}1976-2004 \\
\text { Mercados } \\
\text { de } \\
\text { estaduni- } \\
\text { dense }\end{array}$ & $\begin{array}{l}\text { A sincronicidade é maior para } \\
\text { períodos posteriores à emissão } \\
\text { de ADR's e novas ações. } \\
\text { Informações sobre o } \\
\text { desempenho futuro está } \\
\text { relacionada a um aumento da } \\
\text { sincronicidade, em } \\
\text { contraposição à literatura. }\end{array}$ \\
\hline
\end{tabular}


Quadro 1 (cont.)

\begin{tabular}{|c|c|c|c|c|c|}
\hline Ano & Autores & $\begin{array}{l}\text { Variável } \\
\text { dependente }\end{array}$ & $\begin{array}{l}\text { Variáveis } \\
\text { Explicativas }\end{array}$ & $\begin{array}{l}\text { Período, } \\
\text { Ambiente }\end{array}$ & Principais achados \\
\hline 2011 & $\begin{array}{l}\text { Gul, } \\
\text { Ferdinand } \\
\text { A. } \\
\text { Srinidhi, Bin } \\
\text { Ng, Anthony } \\
\text { C. }\end{array}$ & $\begin{array}{l}\begin{array}{l}\text { Risco } \\
\text { idiossincráti- } \\
\text { co }\end{array} \\
\ln \left(\frac{1-R^{2}}{R^{2}}\right)\end{array}$ & \begin{tabular}{|l|} 
Diversidade de \\
gênero da \\
diretoria; RSPL; \\
volatilidade do \\
RSPL, tamanho, \\
alavancagem, \\
Market to Book, \\
nível de \\
disclosure, nível \\
de governança, \\
qualidade dos \\
lucros, \\
dividendos \\
(dummy)
\end{tabular} & $\begin{array}{l}\text { 2001-2006 } \\
\text { Empresas } \\
\text { estaduni- } \\
\text { denses }\end{array}$ & $\begin{array}{l}\text { Empresas com maior } \\
\text { diversidade de gênero } \\
\text { apresentam maior risco } \\
\text { idiossincrático interpretado } \\
\text { como quantidade de } \\
\text { informações específicas } \\
\text { incorporadas aos preços. }\end{array}$ \\
\hline 2011 & $\begin{array}{l}\text { Rajgopal, } \\
\text { Shiva; } \\
\text { Venkatachal } \\
\text { am, Mohan }\end{array}$ & $\begin{array}{l}\text { Volatilidade } \\
\text { Idiossincrá- } \\
\text { tica, } \\
\text { (variância } \\
\text { dos erros da } \\
\text { regressão } \\
\text { do retorno } \\
\text { sobre os } \\
\text { fatores de } \\
\text { risco). }\end{array}$ & $\begin{array}{l}\text { Qualidade dos } \\
\text { lucros; } \\
\text { Volatilidade do } \\
\text { fluxo de caixa; } \\
\text { desempenho } \\
\text { operacional; } \\
\text { desempenho do } \\
\text { retorno da ação; } \\
\text { tamanho, Book- } \\
\text { to-Market; } \\
\text { alavancagem } \\
\end{array}$ & $\begin{array}{l}\text { 1962-2001 } \\
\text { Mercado } \\
\text { estaduni- } \\
\text { dense }\end{array}$ & $\begin{array}{l}\text { Os autores encontraram } \\
\text { evidências de que a piora na } \\
\text { qualidade dos lucros está } \\
\text { positivamente associada com o } \\
\text { aumento da volatilidade } \\
\text { idiossincrática no período } \\
\text { analisado. }\end{array}$ \\
\hline 2011 & $\begin{array}{l}\text { Stowe, John } \\
\text { D.;Xing, } \\
\text { Xuejing;Rjib } \\
\text { a, Hatem }\end{array}$ & Q de Tobin & $\begin{array}{l}\quad \ln \left(\frac{R^{2}}{1-R^{2}}\right) \\
\text { Tamanho, log do } \\
\text { tempo de vida da } \\
\text { empresa, } \\
\text { lucratividade, } \\
\text { alavancagem, } \\
\text { entre outras } \\
\end{array}$ & $\begin{array}{l}\text { 1970-2004 } \\
\text { Mercado } \\
\text { estaduni- } \\
\text { dense }\end{array}$ & $\begin{array}{l}\text { Empresas com alto } \mathrm{R}^{2} \text { são } \\
\text { maiores, mais antigas, mais } \\
\text { lucrativas e com maior risco } \\
\text { sistemático, menos } \\
\text { endividadas, têm maior } \\
\text { participação de investidores } \\
\text { institucionais e gerenciais, } \\
\text { melhores perspectivas de } \\
\text { crescimento e tendem a ser } \\
\text { sobreapreçadas }^{30} \text {. }\end{array}$ \\
\hline 2011 & $\begin{array}{l}\text { Xing, } \\
\text { Xuejing; } \\
\text { Anderson, } \\
\text { Randy } \\
\text { Xinga, } \\
\text { Xuejing }\end{array}$ & $\begin{array}{l}\text { Sincronici- } \\
\text { dade } \\
\ln \left(\frac{R^{2}}{1-R^{2}}\right)\end{array}$ & $\begin{array}{l}\text { Turnover; } \\
\text { Disclosure } \\
\text { (evidenciação de } \\
\text { itens } \\
\text { relacionados ao } \\
\text { lucro), Variável } \\
\text { construída a } \\
\text { partir da Análise } \\
\text { fatorial das } \\
\text { variáveis: } \\
\text { evidenciação } \\
\text { voluntária; } \\
\text { tamanho, } \\
\text { acompanhament } \\
\text { o de analistas }\end{array}$ & $\begin{array}{l}1995-2004 \\
\text { Epresas } \\
\text { estaduni- } \\
\text { denses } \\
\text { naquele } \\
\text { mercado }\end{array}$ & $\begin{array}{l}\text { A quantidade de informações } \\
\text { específicas da empresa } \\
\text { incorporada em preços das } \\
\text { ações nem sempre é } \\
\text { proporcional às informações } \\
\text { publicamente disponíveis. } \\
\text { Resultados lançam dúvidas } \\
\text { sobre a validade da } \\
\text { sincronicidade como um } \\
\text { indicador da qualidade de } \\
\text { ambiente de informação de } \\
\text { uma empresa. }\end{array}$ \\
\hline
\end{tabular}

(continua)

\footnotetext{
${ }^{30}$ Tradução livre para overpriced
} 
Quadro 1 (cont.)

\begin{tabular}{|c|c|c|c|c|c|}
\hline Ano & Autores & $\begin{array}{l}\text { Variável } \\
\text { dependente }\end{array}$ & $\begin{array}{l}\text { Variáveis } \\
\text { Explicativas }\end{array}$ & $\begin{array}{l}\text { Período, } \\
\text { Ambiente }\end{array}$ & Principais achados \\
\hline 2011 & $\begin{array}{l}\text { Lee, Dong } \\
\text { Wook; Liu, } \\
\text { Mark H.; }\end{array}$ & $\begin{array}{l}\text { Risco } \\
\text { idiossincrá- } \\
\text { tico : } \\
\left(1-\mathrm{R}^{2}\right)\end{array}$ & $\begin{array}{l}\text { PIN (baseado na } \\
\text { medida proposta } \\
\text { por Easley et al. } \\
\text { (2010)); retorno } \\
\text { absoluto dividido } \\
\text { pelo volume } \\
\text { negociado; Erros } \\
\text { de previsão de } \\
\text { analistas; Idade } \\
\text { da empresa; } \\
\text { Investidores } \\
\text { institucionais; } \\
\text { volatilidade da } \\
\text { lucratividade e } \\
\text { tamanho da } \\
\text { empresa }\end{array}$ & $\begin{array}{l}\text { 1983-2004 } \\
\text { Mercado } \\
\text { estaduni- } \\
\text { dense }\end{array}$ & $\begin{array}{l}\text { Os autores não encontraram } \\
\text { evidências de que a volatilidade } \\
\text { dos retornos idiossincráticos } \\
\text { aumenta com a informatividade } \\
\text { preço. Finalmente, existem } \\
\text { evidências de que a volatilidade } \\
\text { dos retornos idiossincráticos } \\
\text { diminui monotonicamente com } \\
\text { informatividade preço. }\end{array}$ \\
\hline 2012 & $\begin{array}{l}\text { Bartram, } \\
\text { Sohnke M. } \\
\text { Söhnke } \\
\text { M.;Brown, } \\
\text { Gregory; } \\
\text { Stulz, René } \\
\text { M. }\end{array}$ & $\begin{array}{l}\text { Diferença no } \\
\text { log do } \mathrm{R}^{2} \text { de } \\
\text { empresas } \\
\text { não } \\
\text { estaduni- } \\
\text { denses e } \\
\text { seus pares } \\
\text { estaduni- } \\
\text { denses }\end{array}$ & $\begin{array}{l}\text { Capitalização do } \\
\text { mercado de } \\
\text { capitais; } \\
\text { liberalização do } \\
\text { mercado de } \\
\text { capitais; } \\
\text { patentes; } \\
\text { disclosure; } \\
\text { direitos dos } \\
\text { credores; } \\
\text { oportunidades de } \\
\text { crescimento } \\
\text { (Market-to-Book) }\end{array}$ & $\begin{array}{l}1990-2006 \\
\text { Diversos } \\
\text { países } \\
\text { comparati- } \\
\text { vamente } \\
\text { aos } \\
\text { Estados } \\
\text { Unidos }\end{array}$ & $\begin{array}{l}\text { Maior volatilidade } \\
\text { idiossincrática não pode ser } \\
\text { considerada algo bom ou ruim } \\
\text { por si só e pode estar } \\
\text { associada a maior crescimento } \\
\text { do bem-estar econômico, } \\
\text { maiores incentivos e incentivos } \\
\text { à inovação e a assumir riscos. } \\
\text { Também podem estar } \\
\text { relacionados a aspectos como } \\
\text { risco político. }\end{array}$ \\
\hline 2012 & $\begin{array}{l}\text { Haw, In- } \\
\text { Mu;Hu, } \\
\text { Bingbing; } \\
\text { Lee, Jay } \\
\text { JunghunWu, } \\
\text { Woody }\end{array}$ & $\begin{array}{l}\text { Retorno das } \\
\text { ações }\end{array}$ & $\begin{array}{l}\text { Disclosure; } \\
\text { Coeficiente de } \\
\text { resposta aos } \\
\text { lucros futuros } \\
\text { (FERC); } \\
\text { qualidade dos } \\
\text { lucros }\end{array}$ & $\begin{array}{l}\text { 1991-2003 } \\
\text { em } 32 \\
\text { países. }\end{array}$ & $\begin{array}{l}\text { Maior divulgação de } \\
\text { informações financeiras, } \\
\text { qualidade do lucro e maior } \\
\text { divulgação de informações } \\
\text { estão associados com os } \\
\text { preços das ações mais } \\
\text { informativos sobre resultados } \\
\text { futuros. Aplicação das leis de } \\
\text { insider trading é associado com } \\
\text { os preços das ações mais } \\
\text { informativos que é maior em } \\
\text { países com instituições fortes } \\
\text { de proteção dos investidores e } \\
\text { os fatores estruturais servem } \\
\text { como mecanismos através dos } \\
\text { quais as instituições de } \\
\text { proteção dos investidores } \\
\text { afetam informatividade preço. }\end{array}$ \\
\hline
\end{tabular}


Quadro 1 (cont.)

\begin{tabular}{|c|c|c|c|c|c|}
\hline Ano & Autores & $\begin{array}{l}\text { Variável } \\
\text { dependente }\end{array}$ & $\begin{array}{l}\text { Variáveis } \\
\text { Explicativas }\end{array}$ & $\begin{array}{l}\text { Período, } \\
\text { Ambiente }\end{array}$ & Principais achados \\
\hline 2012 & $\begin{array}{l}\text { Chen, } \\
\text { Changling;H } \\
\text { uang, Alan } \\
\text { Guoming;Jh } \\
\text { a, Ranjini }\end{array}$ & $\begin{array}{l}\text { Desvio } \\
\text { padrão dos } \\
\text { retornos } \\
\text { idiossincráti } \\
\text { cos }\end{array}$ & $\begin{array}{l}\text { Volatilidade dos } \\
\text { accruals } \\
\text { discricionários, } \\
\text { volatilidade dos } \\
\text { lucros }\end{array}$ & $\begin{array}{l}1978-2009 \\
\text { Mercado } \\
\text { estaduni- } \\
\text { dense }\end{array}$ & $\begin{array}{l}\text { Variação na volatilidade dos } \\
\text { retornos idiossincráticos está } \\
\text { relacionada à volatilidade de } \\
\text { dos accruals discricionários e a } \\
\text { correlação entre ganhos pré } \\
\text { gerenciados e os accruals } \\
\text { discricionários } \\
\end{array}$ \\
\hline 2013 & $\begin{array}{l}\text { An, Heng; } \\
\text { Zhang, Ting }\end{array}$ & $\begin{array}{l}\text { Sincronici- } \\
\text { dade }= \\
\ln \left(\frac{R^{2}}{1-R^{2}}\right)\end{array}$ & $\begin{array}{l}\text { Retorno sobre o } \\
\text { patrimônio } \\
\text { líquido, } \\
\text { Assimetria e } \\
\text { curtose dos } \\
\text { retornos } \\
\text { semanais no } \\
\text { ano, } \\
\text { endividamento, } \\
\text { tamanho da } \\
\text { empresa, } \\
\text { Market to Book } \\
\end{array}$ & $\begin{array}{l}1987-2010 \\
\text { Mercado } \\
\text { estaduni- } \\
\text { dense }\end{array}$ & $\begin{array}{l}\text { A presença de investidores } \\
\text { institucionais dedicados } \\
\text { (transitórios) está } \\
\text { negativamente (positivamente) } \\
\text { relacionada à sincronicidade. }\end{array}$ \\
\hline 2013 & $\begin{array}{l}\text { Chan, } \\
\text { Kalok; } \\
\text { Hameed, } \\
\text { Allaudeen; } \\
\text { Kang, } \\
\text { Wenjin }\end{array}$ & $\begin{array}{l}\text { Liquidez da } \\
\text { ação }\end{array}$ & $\begin{array}{l}\text { Sincronicidade, } \\
\text { Beta, volatilidade } \\
\text { sistemática, } \\
\text { turnover. }\end{array}$ & $\begin{array}{l}1998-2008 \\
\text { Mercado } \\
\text { estaduni- } \\
\text { dense }\end{array}$ & $\begin{array}{l}\text { Os resultados suportam as } \\
\text { duas hipóteses: A } \\
\text { sincronicidade afeta a liquidez } \\
\text { das ações individualmente; } \\
\text { Ações de empresas com maior } \\
\text { volatilidade sistemática ou beta } \\
\text { são mais líquidas. }\end{array}$ \\
\hline 2014 & $\begin{array}{l}\text { Hasan, } \\
\text { Iftekhar; } \\
\text { Song, } \\
\text { Liang; } \\
\text { Wachtel, } \\
\text { Paul }\end{array}$ & $\ln \left(1-R^{2}\right)$ & \begin{tabular}{|l} 
Variáveis que \\
avaliam as \\
diferenças nos \\
aspectos \\
jurídicos das \\
províncias \\
chinesas; \\
Percentual de \\
ações possuídas \\
por estrangeiros; \\
Opacidade \\
(acccrual \\
discricionário); \\
volume, \\
tamanho, \\
alavancagem, \\
Market to book; \\
Q de Tobin \\
defasado \\
\end{tabular} & $\begin{array}{l}\text { 1998-2007 } \\
\text { Mercado } \\
\text { chinês }\end{array}$ & $\begin{array}{l}\text { A sincronicidade preço das } \\
\text { ações é menor quando há } \\
\text { desenvolvimento institucional } \\
\text { em termos de proteção dos } \\
\text { direitos de propriedade e o } \\
\text { Estado de direito. }\end{array}$ \\
\hline
\end{tabular}


Quadro 1 (cont.)

\begin{tabular}{|c|c|c|c|c|c|}
\hline Ano & Autores & $\begin{array}{l}\text { Variável } \\
\text { dependente }\end{array}$ & $\begin{array}{l}\text { Variáveis } \\
\text { Explicativas }\end{array}$ & $\begin{array}{l}\text { Período, } \\
\text { Ambiente }\end{array}$ & Principais achados \\
\hline 2014 & $\begin{array}{l}\text { Boubaker, } \\
\text { Sabri; } \\
\text { Mansali, } \\
\text { Hatem; } \\
\text { Rjiba, } \\
\text { Hatem }\end{array}$ & $\begin{array}{l}\text { Sincronici- } \\
\text { dade } \\
\ln \left(\frac{R^{2}}{1-R^{2}}\right)\end{array}$ & $\begin{array}{l}\text { Excesso do } \\
\text { direito sobre } \\
\text { fluxo de caixa }\end{array}$ & $\begin{array}{l}1998-2007 \\
\text { Mercado } \\
\text { francês }\end{array}$ & $\begin{array}{l}\text { A sincronicidade aumenta com } \\
\text { o excesso de controle. } \\
\text { Empresas com excesso de } \\
\text { controle substancial são mais } \\
\text { propensas a experimentar } \\
\text { grandes retornos negativos. Os } \\
\text { preços das ações das } \\
\text { empresas são menos } \\
\text { síncrônicas e menos propensos } \\
\text { experimentar grandes retornos } \\
\text { negativos quando os acionistas } \\
\text { controladores detêm uma } \\
\text { grande parcela dos direitos de } \\
\text { fluxo de caixa. }\end{array}$ \\
\hline 2014 & $\begin{array}{l}\text { Datta, } \\
\text { Sudip; } \\
\text { Iskandar- } \\
\text { Datta, Mai; } \\
\text { Singh, Vivek }\end{array}$ & $\begin{array}{l}\text { Risco } \\
\text { idiossincrá- } \\
\text { tico } \\
\ln \left(\frac{1-R^{2}}{R^{2}}\right)\end{array}$ & $\begin{array}{l}\text { Acrruals } \\
\text { discricionários; } \\
\text { tamanho; Market } \\
\text { to Book defasado }\end{array}$ & $\begin{array}{l}\text { 1991-2005 } \\
\text { Mercado } \\
\text { estaduni- } \\
\text { dense }\end{array}$ & $\begin{array}{l}\text { Não encontraram evidências de } \\
\text { que a opacidade, medida pelo } \\
\text { accrual discricionário, esteja } \\
\text { relacionado com o risco } \\
\text { idiossincrático. Variabilidades } \\
\text { nas técnicas de calcular o } \\
\text { accrual discricionário podem } \\
\text { gerar resultados que são } \\
\text { significativamente relacionados } \\
\text { com o risco idiossincrático. }\end{array}$ \\
\hline 2014 & $\begin{array}{l}\text { Zhu, Peng } \\
\text { Cheng } \\
\text { Jog, } \\
\text { Vijay } \\
\text { Otchere, } \\
\text { Isaac }\end{array}$ & $\begin{array}{l}\text { Risco } \\
\text { idiossincráti- } \\
\text { co } \\
\ln \left(\frac{1-R^{2}}{R^{2}}\right)\end{array}$ & $\begin{array}{l}\text { Prêmio na } \\
\text { aquisição, } \\
\text { concretização da } \\
\text { aquisição; grau } \\
\text { do controle; } \\
\text { probabilidade de } \\
\text { outra oferta }\end{array}$ & $\begin{array}{l}\text { 1990-2007 } \\
\text { Mercados } \\
\text { emergen- } \\
\text { tes } \\
\text { (20 países, } \\
\text { incluindo o } \\
\text { Brasil) }\end{array}$ & $\begin{array}{l}\text { Empresas com maior } \\
\text { volatilidade idiossincrática em } \\
\text { mercados emergentes são } \\
\text { menos prováveis de serem } \\
\text { adquiridas, mas uma vez que } \\
\text { os adquirentes decidem } \\
\text { adquirir as empresas, pagam } \\
\text { prêmios mais elevados }\end{array}$ \\
\hline
\end{tabular}

A coluna: Variável dependente corresponde à variável dependente do modelo que avaliou a risco idiossincrático (ou sincronicidade). Principais variáveis explicativas são as variáveis utilizadas pelos autores na análise do risco idiossincrático (e/ou sincronicidade). Período corresponde ao período em que o fenômeno foi analisado, ambiente refere-se ao local onde o risco idiossincrático (ou sincronicidade) foi analisado. Principais achados resume os principais resultados relacionados ao risco idiossincrático (e/ou sincronicidade). 


\section{ABORDAGEM METODOLÓGICA}

Neste capítulo estão detalhados os procedimentos metodológicos adotados para avaliar o impacto da concentração acionária e do efeito da comunicação entre empresa e o mercado sobre o risco idiossincrático. Foi analisado o período compreendido entre 2002 e 2012.

\subsection{População e amostra}

A população deste estudo são todas empresas com ações listadas na BM\&FBOVESPA no período compreendido entre janeiro de 2002 a dezembro de 2012. Este período foi escolhido em função da estabilidade econômica após a crise de 1998 e da unificação das bolsas de valores do Rio de Janeiro e de São Paulo além da incorporação pela BM\&FBovespa dos negócios de todas as bolsas de valores do Brasil em 2000.

Como o horizonte de mensuração do indicador de risco idiossincrático é de um ano, calculado com base em cotações semanais, compuseram a amostra ações que tiveram no mínimo uma cotação semanal em cada ano.

Além disso, para minimizar possíveis distorções foram eliminadas as ações que não foram negociadas no mínimo semanalmente no ano imediatamente anterior e no ano imediatamente posterior à medição do risco idiossincrático. Também foram excluídas as ações das empresas que abriram ou fecharam o capital em datas próximas à coleta de dados de cada ano. Dessa forma, as ações que fizeram parte da amostra foram negociadas no mínimo uma vez por semana no ano a; a-1 e a+1 $1^{31}$. As ações que compuseram a amostra não foram necessariamente as mesmas em cada ano. Quando duas ações de uma mesma empresa cumpriam os requisitos mínimos de negociação, foi selecionada a ação com maior volume de negociação no ano.

As cotações das ações foram ajustadas aos proventos e coletadas na base de dados Economática $\Theta$, assim como as informações contábeis. Os dados relativos a participação acionária e as datas de divulgação dos relatórios anuais foram coletadas diretamente no sítio eletrônico da Comissão de Valores Mobiliários.

31 Por exemplo, as ações que compuseram a amostra referente ao ano de 2005 foram aquelas que tiveram no mínimo um negócio por semana nos anos de 2004, 2005 e 2006. 
O detalhamento da quantidade de ações/empresas por ano selecionadas que atenderam aos critérios de seleção está apresentado na Tabela 1

\begin{tabular}{|c|c|}
\hline Ano & $\begin{array}{l}\text { Quantidade de ações/ empresas } \\
\text { selecionadas }\end{array}$ \\
\hline 2.002 & 96 \\
\hline 2.003 & 97 \\
\hline 2.004 & 108 \\
\hline 2.005 & 117 \\
\hline 2.006 & 108 \\
\hline 2.007 & 117 \\
\hline 2.008 & 140 \\
\hline 2.009 & 204 \\
\hline 2.010 & 206 \\
\hline 2.011 & 198 \\
\hline 2.012 & 204 \\
\hline Total & 1.595 \\
\hline
\end{tabular}

\subsection{Variáveis do estudo}

\subsubsection{Risco Idiossincrático}

IDIO: RISCO IDIOSSINCRÁTICO:

O risco idiossincrático corresponde ao percentual das variações do retorno da ação não explicado pelos fatores sistemáticos. É obtido a partir do coeficiente de determinação $\left(R^{2}\right)$ da regressão linear do excesso de retorno da ação em função dos fatores sistemáticos. IDIO, que corresponde à medida do risco idiossincrático é dada pela fórmula 38 :

$$
I D I O=\ln \left(\frac{1-R^{2}}{R^{2}}\right)
$$

Vale lembrar que o risco idiossincrático $\left(I D I O_{j, a}\right)$ e a sincronicidade $\left(\operatorname{SINC}_{j, a}\right)$ são medidos a partir do coeficiente de determinação do modelo de regressão linear dos retornos semanais da ação da empresa j no ano a em relação aos fatores sistemáticos 
$\left(R^{2}\right)$, o qual que refere-se ao percentual de variações dos retornos explicados pelo retorno do mercado em relação à variância total dos retornos da ação (e portanto uma medida relativa de risco idiossincrático). Então, $\left(I D I O_{j, a}=-\operatorname{SINC} C_{j, a}\right) \therefore$

$$
\begin{gathered}
\operatorname{SINC}_{j, a}=\log \left(\frac{R_{j, a}^{2}}{1-R_{j, a}^{2}}\right)=\log \left(\frac{1-R_{j, a}^{2}}{R_{j, a}^{2}}\right)^{-1}=-1 \times \log \left(\frac{1-R_{j, a}^{2}}{R_{j, a}^{2}}\right)=-I D I O_{j, a} \\
\therefore\left(I D I O_{j, a}\right)=\log \left(\frac{1-R_{j, a}^{2}}{R_{j, a}^{2}}\right)
\end{gathered}
$$

Onde:

$I D I O_{j, a}$ mede o risco idiossincrático da ação da empresa j no ano a.

$R_{j, a}^{2}$ é o coeficiente de determinação do modelo de regressão linear dos retornos semanais da ação da empresa j no ano a em relação aos fatores sistemáticos.

Admitindo-se uma relação linear entre o retorno esperado de um ativo e os fatores de risco sistemático e utilizando o método dos mínimos quadrados, considera-se que a parcela do retorno do ativo não explicada pelos fatores sistemáticos está relacionada aos fatores específicos ou idiossincráticos.

Nesse sentido, a aplicação do método dos mínimos quadrados para obter a equação da regressão linear tem a função de separar o retorno devido aos fatores sistemáticos do retorno decorrente dos fatores específicos (ou idiossincrático). Operacionalmente, o retorno idiossincrático é representado pelo termo de erro da regressão linear que estima a relação entre o retorno da ação e os fatores sistemáticos.

Portanto, para desmembrar o retorno total em seus componentes sistemático e idiossincrático foram usados os fatores notadamente identificados na vasta literatura financeira sobre o tema. O termo de erro estocástico capturou, então, o efeito das variáveis omitidas do modelo, mas que coletivamente afetam o retorno da ação e é uma variável aleatória não observável (Gujarati, 2006, pp. 34-35). 
Como a intenção nesta pesquisa foi isolar os efeitos das informações que afetam conjuntamente todas as empresas (fatores sistemáticos) dos efeitos intrinsicamente aleatórios do comportamento humano (Gujarati, 2006, p. 36), o termo de erro estocástico cumpre com o papel de representar as variações no retorno da ação decorrentes do comportamento humano ${ }^{32}$.

A escolha por um modelo que seja o mais simples possível seguiu o princípio da parcimônia. Gujarati (2006, p. 36) esclarece que variáveis explanatórias só deverão ser incluídas no modelo se houver uma teoria suficientemente forte para sugerir tal inclusão.

Além disso, nesta pesquisa assim como em Morck et al (2000, p. 224), as regressões especificadas se assemelham às equações de precificação de ativos clássicos. Não se busca, nesses modelos, a precificação de ativos uma vez que a abordagem segue a aplicação dos enfoques de Roll (1988) e Grossman (1976) acerca da capitalização de informações nos preços e, por essa razão, a ênfase não recai sobre o tradeoff entre risco e retorno.

O retorno do mercado foi usado como variável explicativa do comportamento do retorno da ação. Além do retorno do mercado brasileiro (IBRX), em um dos modelos foi usado o retorno do mercado estadunidense (S\&P 500).

Não foi aplicado o modelo de três fatores de Fama e French (1993) sobretudo porque o referido modelo incorpora elementos que são específicos da empresa, como o porte da empresa e a relação entre valor patrimonial e o de mercado, os quais compõe variáveis do modelo que relaciona o risco idiossincrático às características específicas de cada empresa.

Por outro lado, embora autores como Roll (1988), Morck et al. (2000) Piotroski e Roulstone (2004) tenham incluído o retorno do setor como variável explicativa no modelo de regressão, no caso dos mercados emergentes, tal inclusão pode representar um problema. Isso porque tanto no Brasil quando em outras economias emergentes, vários setores da economia são representados por um pequeno número

\footnotetext{
32 Importante salientar que nesta pesquisa é adotada a abordagem de finanças comportamentais de tal forma que as variações dos preços das ações estão relacionadas às interpretações das informações pelos investidores que nem sempre se comportam racionalmente.
} 
de empresas. Desse modo, o resultado obtido se o retorno de um setor for computado com um pequeno número de empresas, representará as especificidades de algumas poucas empresas e não refletirá, como desejável, o comportamento setorial. Desse modo, acompanhando Chan e Hameed (2006), nesta pesquisa o modelo usado para capturar o retorno idiossincrático não incluiu o retorno do setor como fator explicativo do retorno da ação.

No entanto, considerando a integração entre os mercados de capitais brasileiro e estadunidense, alternativamente um dos modelos utilizados para avaliar o risco idiossincrático incluiu o retorno do índice S\&P 500 como variável explicativa do retorno da ação.

Modelo 1: $R E T_{j, a}=\propto+\beta_{1} R_{m, a}+\varepsilon_{j, a}$

Modelo 2: $\quad R E T_{j, a}=\propto+\beta_{1} R_{m, a}+\beta_{2} R_{s \& p 500, a}+\varepsilon_{j, a}$

Modelo 3: $\quad R E T_{j, a}=R_{f, a}+\beta_{1}\left(R_{m, a}-R_{f, a}\right)+\varepsilon_{j, a}$

\section{Onde}

$R E T_{j, a}$ é o retorno semanal da empresa $j$ no ano $a$,

$R_{m, a}$ é o retorno semanal do mercado, representado pelo retorno do Índice Brasil, que é um índice de preços que mede o retorno de uma carteira teórica composta por 100 ações selecionadas entre as mais negociadas na BOVESPA, em termos de número de negócios e volume financeiro (IBRX).

$R_{S \& p 500, a}$ é o retorno semanal do índice S\&P $500^{33}$ (Índice composto por 500 ações de empresas negociadas no mercado estadunidense, proxy do retorno de mercado estadunidense) no ano a

\footnotetext{
33 Índice composto por 500 ações de empresas negociadas no mercado estadunidense. As empresas são selecionadas de acordo com o tamanho, liquidez e representação de grupo industrial. Davies Junior (2010) demonstra que a volatilidade dos retornos das ações nos setores por ele analisados é explicada, em parte, pelo retorno do índice S\&P 500.
} 
$R_{f, a}$ é o retorno semanal da poupança, representando o retorno do ativo livre de risco no ano $a$

$I D I O \_n=\ln \left(\frac{1-R_{\text {mod_n }}^{2}}{R_{\text {mod_n }}^{2}}\right)$ refere-se à medida do risco idiossincrático calculada a partir do coeficiente de determinação $\left(\mathrm{R}^{2}\right)$ do modelo mod_n $(n=1$ a 3$)$

Para cada ano foram obtidos os valores do coeficiente de determinação $\left(R^{2}\right)$ das regressões do retorno da ação (medido na forma logarítmica) sobre os fatores sistemáticos, conforme descritos em cada modelo para cada empresa em cada um dos anos. Então, cada regressão considerou os retornos observados de 52 semanas em cada ano.

Foram excluídas da análise os resultados das ações das empresas em que a regressão linear no ano não apresentou normalidade dos resíduos. A Tabela 2 detalha o número de ações de empresas que permaneceram na amostra:

Tabela 2: Número de observações por ano das empresas em que o R2 foi validado estatisticamente

\begin{tabular}{cccc}
\hline Ano & $\begin{array}{c}\text { Nr de observações } \\
\text { na amostra Inicial }\end{array}$ & $\begin{array}{c}\text { Nr de observações } \\
\text { na amostra final }\end{array}$ & $\%$ \\
\hline 2.002 & 96 & 75 & $78,1 \%$ \\
2.003 & 97 & 68 & $70,1 \%$ \\
2.004 & 108 & 69 & $63,9 \%$ \\
2.005 & 117 & 88 & $75,2 \%$ \\
2.006 & 108 & 68 & $63,0 \%$ \\
2.007 & 117 & 80 & $68,4 \%$ \\
2.008 & 140 & 105 & $75,0 \%$ \\
2.009 & 204 & 131 & $64,2 \%$ \\
2.010 & 206 & 153 & $74,3 \%$ \\
2.011 & 198 & 157 & $79,3 \%$ \\
2.012 & 204 & 147 & $72,1 \%$ \\
Total & 1.595 & 1.141 & $71,5 \%$ \\
\hline
\end{tabular}

Detalhamento do número de ações de empresas por ano após a exclusão das observações em que os resíduos da regressão não apresentaram normalidade em pelo menos um dos modelos utilizados para avaliar o risco idiossincrático e a sincronicidade. 


\subsubsection{Concentração de propriedade}

Para avaliar o impacto da estrutura de propriedade sobre o risco idiossincrático, foram usadas a variáveis que indicam a parcela dos direitos de propriedade detidos pelos maiores acionistas.

CONC_P : A variável corresponde à porcentagem das ações detidas pelo maior acionista com participação mínima seja de $5 \%$ em relação ao total das ações. Brockman e Yan (2009) verificaram que as ações de empresas com grupos de aciontas com grandes participações detêm parcela importante das informações específicas da empresa, maior risco idiossincrático e menor sincronicidade com o mercado.

Por questões econométricas, procedeu-se à transformação logarítmica:

$$
\text { CONC_P } P_{J, a}=\ln \left(\frac{P A R T_{\text {maior } J, a}}{1-P A R T_{\text {maior }, a}}\right)
$$

Onde

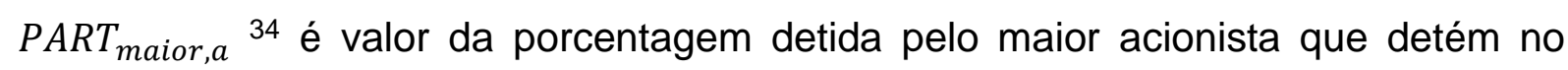
mínimo $5 \%$ do total das ações da empresa $j$ no ano a

CONC_3 : A variável corresponde à porcentagem das ações detidas em conjunto pelos três maiores acionista com participação mínima seja de $5 \%$ do total das ações cada um deles.

$$
\operatorname{CONC}_{-} 3_{j, a}=\ln \left(\frac{P A R T_{j 3, a}}{1-P A R T_{j 3, a}}\right)
$$

\footnotetext{
34 Os dados sobre participação acionária foram obtidos diretamente dos Informes anuais no site da Comissão de Valores Mobiliários os anos anteriores a 2009 e nos formulários de referência nos anos seguintes. Embora a informação exista no banco de dados da base Economárica ${ }^{\circledR}$, divergências entre os dados apresentados e aqueles existentes no banco de dados da CVM tornaram necessária a obtenção das referidas informações diretamente da CVM.
} 
$P A R T_{j 3, a}$ é a soma das porcentagens detidas pelos três maiores acionistas que detém, cada um, no mínimo 5\% do total das ações da empresa $j$ no ano a

Quando nenhum acionista detém pelo menos $5 \%$ das ações da empresa, os valores de $P A R T_{\text {maior, } a}$ e $P A R T_{j 3, a}$ é zero.

\subsubsection{Opacidade corporativa}

Como proxy de opacidade corporativa foram usadas duas metodologias distintas. Uma delas está apoiada na resposta do mercado aos anúncios de resultados quando da divulgação dos relatórios contábeis obrigatórios (PEAD) ${ }^{35}$ e a outra medida de opacidade usada refere-se àquela identificada na literatura por accruals discricionários e que relaciona os indicadores de gerenciamento de resultados à falta de transparência da empresa em relação aos investidores.

\subsubsection{Opacidade como "post earnings annoucement drift" (PEAD)}

O indicador PEAD foi usado como medida da não-transparência corporativa (opacidade). A escolha está apoiada na teoria do papel confirmatório das demonstrações contábeis. Proposta por Gigler et al. (1998) e reforçada por estudos como aquele conduzido por Ball et al. (2012), considera-se que os demonstrativos contábil-financeiros obrigatórios têm papel confirmatório das informações anteriormente divulgadas. Entende-se, então, que as oscilações de preços das ações em torno dos anúncios anuais de resultados (os retornos anormais) refletem a incorporação das informações não divulgadas voluntariamente. Nesse sentido, a magnitude do retorno anormal pode ser considerada um indicativo do grau de opacidade corporativa.

Portanto o indicador de transparência (ou seu oposto - opacidade) não tratará da qualidade dos demonstrativos contábeis divulgados, mas dos efeitos de todas as informações divulgadas tempestivamente e relevantes sobre o desempenho futuro da empresa. A precificação e incorporação nos preços das ações dos eventos que ocorreram antes da divulgação e não foram tempestivamente e de maneira clara

\footnotetext{
35 PEAD é a sigla para Post Earnings Announcement Drifit, que significa oscilações pós anuncio dos resultados e sua utilização está detalhada nos parágrafos seguintes.
} 
revelados ao mercado, serão precificados e incorporados aos preços no momento em que forem divulgados nos relatórios obrigatórios. Essa informação precificada corresponde à variação nos preços das ações em torno da data da divulgação, indicando o grau de surpresa do mercado em relação às novas informações divulgadas nos demonstrativos financeiros obrigatórios auditados.

Considerando que os demonstrativos contábeis refletem os eventos que ocorreram há pelo menos 30 dias da publicação (em média 50 dias, desde o início do trimestre até a efetiva divulgação), é razoável supor que empresas comprometidas com a transparência perante os investidores já tenham divulgado os eventos significativos que afetam os resultados futuros da empresa mesmo antes da publicação oficial dos demonstrativos contábeis. Então, as oscilações nos preços das ações em torno da publicação dos demonstrativos contábeis obrigatórios estão relacionadas à opacidade. É um sinal de que as informações não foram divulgadas tempestivamente pelos gestores que, portanto, não foram transparentes aos investidores. Tais flutuações nos preços das ações em torno da data de divulgação são conhecidas na literatura por "Post Earning Announcement Drift - PEAD", relatado inicialmente por Ball e Brown (1968) e documentado como uma anomalia por Ball(1978), Bernard \& Thomas, (1989) e Foster, Olsen, \& Shevin,(1984) ${ }^{36}$,entre outros e estão associadas às variações inesperadas nos lucros.

Destarte, a teoria subjacente ao uso da medida PEAD como indicativo da opacidade corporativa é a de que os demonstrativos contábeis obrigatórios têm a função de confirmar as informações anteriormente divulgadas pela empresa, quaisquer que sejam os mecanismos utilizados. A esse papel dos demonstrativos contábeis obrigatórios é atribuída a expressão "papel confirmatório dos demonstrativos contábeis", conforme descrito por Gigler (1998) e estudado por autores como Ball et al. (2012) .

A variável usada como proxy de não-transparência ou opacidade corporativa nesta pesquisa difere substancialmente dos indicadores de evidenciação (disclosure) conhecidos na literatura contábil, pois não foi avaliada a qualidade das informações

${ }^{36}$ Foster, Olsen e Shevin (1984) 
contábeis obrigatórias divulgadas, mas se as informações anteriormente divulgadas foram suficientes para o investidor avaliar o desempenho então refletido no demonstrativo contábil divulgado.

A construção da variável que avalia a não-transparência (então opacidade) está alinhada com a definição de transparência corporativa proposta por Bushman et al (2004, p. 208) : "a disponibilização de informações específicas da empresa para terceiros das empresas de capital aberto." 37

Dessa forma, considera-se que o grau de variação dos preços nas datas em torno da divulgação das informações contábeis obrigatórias corresponde à precificação e incorporação nos preços das surpresas em relação às informações disponíveis no mercado acerca dos eventos que tem impacto econômico para a empresa.

Para medir a variação nos preços das ações devido às novas informações divulgadas nos demonstrativos contábeis obrigatórios foi usada a metodologia de Estudos de Evento pressupondo que dada a racionalidade do mercado, os efeitos do evento serão refletidos imediatamente no preço das ações.

A metodologia consiste em se obter, por meio de um modelo estatístico, os retornos esperados (chamados de retornos normais ${ }^{38}$ ) os quais devem ser diminuídos dos retornos efetivamente observados nas datas próximas ao evento, obtendo-se a medida dos "retornos anormais" (AR) ${ }^{39}$. Retorno "anormal", então, refere-se ao retorno da ação pós evento diminuído do retorno esperado (MacKinlay, 1997; McWilliams \& Siegel, 1997).

Para cada empresa i, em cada ano a será calculado o retorno anormal de tal forma que:

$$
\mathrm{AR}_{\mathrm{id}}=\mathrm{R}_{\mathrm{dt}}-\widehat{\mathrm{R}_{\mathrm{ld}}}
$$

\footnotetext{
37 "the availability of firm-specific information to those outside publicly traded firms"

${ }^{38}$ Nesse caso, o termo "normal" não se refere à distribuição gaussiana, mas sim ao que seria esperado, ou seja: normal, em contraposição ao extraordinário, chamado de "anormal".

39 "abnormal return"
} 


\section{Onde}

$\mathrm{AR}_{\mathrm{id}}=$ Retorno anormal da empresa i no dia $\mathrm{d}$

$\mathrm{R}_{\mathrm{id}}=$ Retorno observado da empresa i no dia d (obtido na forma logarítmica)

$\widehat{\mathrm{R}_{\mathrm{d}}}=$ Retorno esperado da empresa i no dia d (obtido na forma logarítmica)

O retorno anormal será simultaneamente normalmente distribuído com média zero e variância $\sigma^{2}\left(A R_{i d}\right)$ (MacKinlay, 1997)

Nesta pesquisa o modelo de mercado foi usado para estimar o retorno esperado (ou normal) e o período anterior ao evento (nesse caso, a data da divulgação dos relatórios anuais) usado como base de dados para estimar o modelo de retorno esperado é chamado de "janela de estimação". A janela do evento consiste nas datas em torno do evento, definida para capturar o efeito dele sobre o valor da empresa. Esquematicamente tem-se:

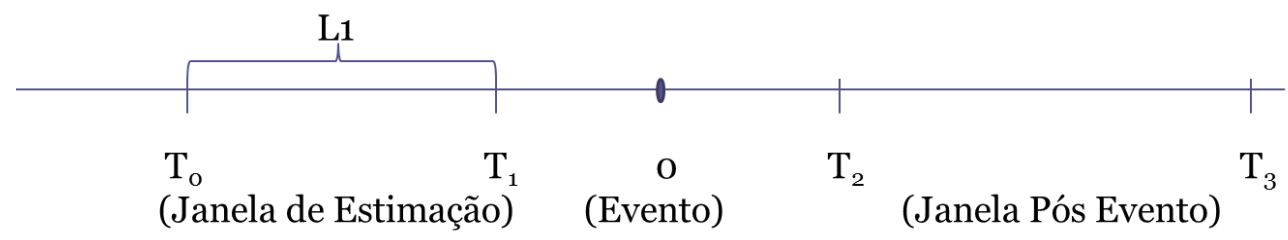

Figura 1: Linha do tempo para um estudo de evento.

Adaptado de MacKinley (1997)

Dessa forma, a variância dos retornos anormais é dada pela equação:

$$
\sigma^{2}\left(A R_{i d}\right)=\sigma_{\varepsilon i}^{2}+\frac{1}{L_{1}} \sigma_{a d, i}^{2}
$$

$\sigma_{\varepsilon i}^{2}=$ Variância dos erros do modelo usado para estimar os retornos normais

$\sigma_{a d, i}^{2}=$ Variância adicional devido ao erro de amostragem dos coeficientes do modelo de previsão dos retornos normais

$L_{1}$ = Tamanho da janela de estimação

Dessa forma, na medida em que $L_{1}$ aumenta, $\frac{1}{L_{1}} \sigma_{a d, i}^{2}$ tende a zero e : 


$$
\sigma^{2}\left(A R_{i t}\right)=\sigma_{\varepsilon i}^{2}
$$

O retorno acumulado na janela do evento é denominado "retorno anormal acumulado" (ou Cumulative abnormal return - CAR). O retorno anormal acumulado (CAR) é dado pela equação:

$$
\operatorname{CAR}_{i}\left(T_{1}, T_{2}\right)=\sum_{\tau=T 1}^{T 2} A R_{i t}
$$

Considerando que os retornos anormais são independentes, a variância do retorno anormal acumulado $\sigma_{i}^{2}\left(\boldsymbol{T}_{1}, \boldsymbol{T}_{2}\right)$ é dada pela equação:

$$
\sigma_{i}^{2}\left(T_{1}, T_{2}\right)=\left(T_{1}-T_{2}+1\right) \sigma_{\varepsilon i}^{2}
$$

Foram usadas duas janelas de evento, descritas a seguir:

JANELA 1: Período entre a data da divulgação e dois dias seguintes à divulgação dos relatórios contábeis obrigatórios

JANELA 2: Período entre a data da divulgação e quatro dias seguintes à divulgação dos relatórios contábeis obrigatórios

Os retornos anormais acumulados foram padronizados dividindo o retorno anormal acumulado pela estimativa de desvio padrão, dado pela equação:

$$
\operatorname{SCAR}_{i}\left(T_{1}, T_{2}\right)=\frac{\operatorname{CAR}_{i}\left(T_{1}, T_{2}\right)}{\sqrt{\sigma_{i}\left(T_{1}, T_{2}\right)}}=\frac{\operatorname{CAR}_{i}\left(T_{1}, T_{2}\right)}{\sqrt{\left(T_{1}-T_{2}+1\right)} \sigma_{\varepsilon i}}
$$

Onde $\operatorname{SCAR}_{i}\left(T_{1}, T_{2}\right)$ é o retorno anormal padronizado para a empresa i ao longo da janela de estimação T1 aT2.

Foram obtidos os $\operatorname{SCAR}_{i}\left(T_{1}, T_{2}\right)$ em cada ano para cada empresa e a medida representa a precificação das informações "novas" divulgadas nos demonstrativos contábeis obrigatórios e indica o grau de opacidade (oposto à transparência). 
Cabe salientar que os retornos anormais acumulados podem ser positivos ou negativos com reflexo no aumento ou redução do valor da firma, pois referem-se ao impacto das informações não antecipadas que foram divulgadas nos demonstrativos contábeis. Entretanto, para efeito da avaliação da opacidade (não-transparência), a dimensão do retorno é relevante, não o sinal (positivo ou negativo). Além disso, com base na hipótese do papel confirmatório dos demonstrativos contábeis, quanto menor a magnitude do retorno anormal acumulado, menos informações novas foram divulgadas nos demonstrativos contábeis e, dessa forma maior a transparência da empresa em relação ao mercado, independente se afetaram positiva ou negativamente o valor da empresa.

$$
\begin{gathered}
P E A D_{i, a}=\left|\operatorname{SCAR}_{i}\left(T_{1}, T_{2}\right)\right| \\
P E A D_{-} 1_{i, a}=\left|\operatorname{SCAR} R_{i}\left(T_{-1}, T_{+2}\right)\right| \\
P E A D_{-} 2_{i, a}=\left|\operatorname{SCAR} R_{i}\left(T_{-1}, T_{+4}\right)\right|
\end{gathered}
$$

Como foram usados indicadores relativos a duas janelas de evento (janela 1 e janela 2), as variáveis estão assim definidas:

\section{Onde}

PEAD_1 é a medida da opacidade corporativa relativa à janela de evento 1 para a empresa $i$ no ano a e

PEAD_2 é a medida da opacidade corporativa relativa à janela de evento 2 para a empresa $i$ no ano a

T corresponde à data do evento e o subscrito o número de dias que antecedeu ou sucedeu à data do evento.

Cabe mencionar que, com base em informações da CVM, as informações relativas às datas da publicação dos demonstrativos contábeis obrigatórios anteriores a 2010 só incluem a data da reapresentação mais recente em cada ano. Então, nos casos anteriores a 2010 em que a empresa republicou as demonstrações contábeis, as datas da publicação da primeira versão das demonstrações contábeis foram obtidas 
no relatório denominado: Calendário de Eventos Corporativos, que são divulgados pelas empresas. Tal relatório é obrigatório para as empresas que aderiram a algum nível de governança diferenciado proposto pela BM\&FBOVESPA (segmentos como Bovespa Mais, Novo Mercado, Nível 2 e Nível 1) e facultativo para as demais. Portanto, as datas das publicações das demonstrações contábeis anuais foram coletadas na medida da disponibilidade da informação.

\subsubsection{Accruals discricionários como opacidade corporativa - OPAC}

Analogamente a Hutton et al. (2009) a medida de opacidade foi obtida pela soma móvel do valor absoluto dos accruals discricionários dos três anos anteriores ${ }^{40}$ :

$$
O P A C_{i t}=\left|D A_{i t-3}\right|+\left|D A_{i t-2}\right|+\left|D A_{i t-1}\right|
$$

Para medir os accruals discricionários foi usado o Modelo de Jones (1991) modificado por Dechow et al.(1995). Foi estimada a equação abaixo para cada ano de 1998 a 2009:

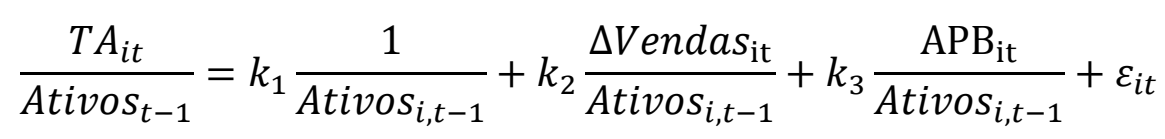

Em que para a firma i no ano t, TA representa o accrual total definido como:

$T A_{i t}=L_{A I E O D_{i t}}-F C O_{i t}$ onde LAIEOD é o lucro antes dos itens extraordinários e das operações descontinuadas e FCO o fluxo de caixa operacional extraído da demonstração do fluxo de caixa.

Ativos $_{t-1}$ representa o total do ativo do período anterior; $\Delta V e n d a s_{\mathrm{it}}$ é a variação das vendas em relação ao período anterior; $\mathrm{APB}_{\text {it }}$ é o ativo permanente bruto (ou seja, antes dos efeitos da depreciação acumulada)

Os coeficientes estimados a partir da equação 55 foram usados para estimar os accruals normais $N A_{i t}$ para toda a amostra com base na equação 56 .

\footnotetext{
${ }^{40} \mathrm{Na}$ e Zhang (An \& Zhang, 2013) também usaram a métrica proposta por Hutton et al. (2009) como proxy de opacidade.
} 


$$
N A_{i t}=\widehat{k_{1}} \frac{1}{\operatorname{Ativos}_{i, t-1}}+\widehat{k_{2}} \frac{\Delta \text { Vendas }_{\text {it }}-\Delta R E C_{i t}}{\text { Ativos }_{i, t-1}}+\widehat{k_{3}} \frac{\mathrm{APB}_{\mathrm{it}}}{\operatorname{Ativos}_{i, t-1}}
$$

$\triangle R E C_{i t}$ refere-se ao valor dos recebíveis da empresa i no ano $t$ diminuído dos recebíveis no ano $\mathrm{t}-1$

A medida do accrual discricionário em cada ano t é medido pela diferença entre o accrual total e o accrual normal estimado para cada empresa:

$$
D A_{i t}=\left(\frac{T A_{i t}}{\operatorname{Ativos}_{i t}}\right)-N A_{i t}
$$

Cumpre salientar que a mudança no padrão contábil implementada nos relatórios contábeis em 2010 impediu a utilização dos dados em relação ao ano anterior. Ainda que as empresas tenham sido obrigadas a reportar, além dos demonstrativos contábeis no novo padrão, as informações comparáveis naquele ano, sua utilização para a medir a discricionariedade na aplicação dos accruals ficou comprometida, na interpretação da autora da pesquisa. Portanto, como a medida de opacidade toma como base os accruals discricionários nos três anos anteriores, foram construídas medidas que avaliam a opacidade entre os anos 2002 e 2010.

Além disso, como foram necessárias as informações contábeis de quatro anos anteriores à data da avaliação da opacidade para cada empresa, nem sempre foi possível obter os dados necessários em virtude de algumas empresas terem fechado o capital no período ou terem aberto o capital a menos de quatro anos anteriormente à análise.

Além disso, vale lembrar que a metodologia para apuração dos accruals discricionários não se aplica para empresas do setor financeiro. 


\subsubsection{Variáveis de controle}

Foram consideradas como variáveis de controle aquelas que representam as características específicas das empresas que têm sido mencionadas na literatura como afetando o risco idiossincrático:

VM : logarítmo natural do valor de mercado das ações em março de cada ano é a proxy do porte da empresa. Foi usada em estudos como Brown e Kapadia (2007), Hutton et al. (2009) entre outros. Os valores foram corrigidos pelo Índice de Preços ao Consumidor Ampliado (IPCA) para valores de março de 2012.

Potencialmente, grandes empresas são mais diversificadas, atuando em vários segmentos de mercado fato que explicaria de certa forma um menor risco idiossincrático ou uma maior sincronicidade dos retornos das ações em relação ao comportamento do mercado (Piotroski \& Roulstone, 2004; Roll, 1988).

Kelly (2005) esclarece que empresas maiores atraem a atenção de analistas e a exposição da empresa ao mercado é um indicativo de eficiência informacional.

LIQ : Liquidez em bolsa reflete a capacidade de negociar grandes quantidades de uma ação de forma rápida, com custo mínimos de transação e pouco impacto sobre os preços. Existem suportes teóricos e empíricos que relacionam negativamente (positivamente) liquidez e risco idiossincrático (sincronicidade) (Chan et al., 2013). Bali, Cakici, Yan e Zhang (2005) relacionam o risco idiossincrático e liquidez pela possibilidade de serem negociadas grandes quantidades de ações a baixo custo e sem que seja induzida grande mudança no preço.

Como variável que mede a liquidez (LIQ) foi usada a medida Liquidez em Bolsa obtida na base de dados Economática $\AA$, obtida da seguinte maneira:

$$
\text { Liquidez em bolsa }=100 \times \frac{p}{P} \times \sqrt{\frac{n}{N} \times \frac{v}{V}}
$$

onde:

$p=$ número de dias em que houve pelo menos um negócio com a ação dentro do período escolhido

$\mathrm{P}=$ número total de dias do período escolhido 
$\mathrm{n}=$ número negócios com a ação dentro do período escolhido

$\mathrm{N}$ = número de negócios com todas a ações dentro do período escolhido

$\mathrm{v}=$ volume em dinheiro com a ação dentro do período escolhido

$\mathrm{V}=$ volume em dinheiro com todas a ações dentro do período escolhido

MtB: Market-to-book definido como a razão entre o valor de mercado das ações e o valor patrimonial da ação, medido no início do ano fiscal. Na literatura, o indicador Market-to-book é uma proxy das oportunidades de crescimento das firmas (An \& Zhang, 2013; Bartram et al., 2012; G. Brown \& Kapadia, 2007; Dasgupta et al., 2010; Datta et al., 2014; F. a. Gul et al., 2010; Hutton et al., 2009; Rajgopal \& Venkatachalam, 2011).

MtB mede a extensão em que o valor contábil do patrimônio líquido está subestimado em relação ao valor de mercado das ações (Roychowdhury \& Watts, 2006), e por esse motivo é razoável supor que esteja relacionado com o risco idiossincrático (e consequentemente também com a sincronicidade) (Hutton et al., 2009). A assimetria de informações deve ser maior em empresas com maiores oportunidade de crescimento em razão das divergências acerca dos investimentos em ativos que correspondem àqueles necessários ao aproveitamento das referidas oportunidades (Myers \& Majluf, 1984) e, por esse motivo os retornos das ações seriam mais voláteis como decorrência de fatores específicos (idiossincráticos). Acompanhando Bartram et al (2012), os valores observados de MtB maiores do que 20 foram substituídos por 20.

ENDIV: endividamento definido como a relação entre a dívida bruta e o patrimônio líquido, medido no início do período, é semelhante ao indicador usada como variável de controle em estudos como aqueles conduzidos por Hasan et al. (2014), An e Zhang (2013) e Stowe e Xing (2011).

O endividamento (ENDIV) deve afetar o risco idiossincrático e a sincronicidade pelo impacto sobre a sensibilidade dos retornos às condições macroeconômicas. Além disso ele interfere na divisão do risco entre os detentores do patrimônio e aqueles que detém os direitos sobre as dívidas. Os detentores do patrimonio detém a maior parte do risco idiossincrático e, dessa forma, o endividamento deve reduzir o risco idiossincrático (Hutton et al., 2009). Por outro lado, Rajgopal e Venkatachalam (2011) 
argumentam que empresas endividadas estão mais sujeitas a dificuldades financeiras, sugerindo uma associação positiva entre endividamento e o risco idiossincrático.

RSPL: Retorno sobre o Patrimônio Líquido, definido como lucro líquido dividido pelo valor contábil do patrimônio líquido medido no início do ano fiscal foi usado por autores entre os quais Hutton et al.(2009) e Gul et al. (2011) e Zhang (2013).

TURN: Turnover é a relação entre o número de negociações das ações da empresa no ano e número de ações outstanding. Por questões econométricas a usou-se a transformação logarítmica da medida. Deve estar relacionado à sincronicidade e ao risco idiossincrático pois as ações de empresas que são mais ativamente negociadas estão mais propensas a refletir nos preços tanto as informações específicas quanto as do mercado (Brockman \& Yan, 2009). A associação entre turnover e o risco idiossincrático deve ser positiva se um maior nível de negociação representar um aumento das informações específicas incorporadas aos preços das ações. Entretanto, se as negociações não estiverem relacionadas aos fundamentos e $\mathrm{R}^{2}$ for uma proxy para noise trading, então espera-se que a relação entre turnover e o risco idiossincrático seja negativa (Ashbaugh-skaife, Gassen, \& LaFond, 2005). A Tabela 3 resume a forma pela qual as variáveis foram definidas.

\section{Tabela 3: Definição das Variáveis}

\begin{tabular}{|c|c|c|}
\hline Sigla & Nome & Descrição \\
\hline $\begin{array}{l}\mathrm{R}^{2}-1 \\
\mathrm{R}^{2}-2 \mathrm{e} \\
\mathrm{R}^{2}-3\end{array}$ & $\begin{array}{l}\text { Coeficiente de } \\
\text { Determinação }-\mathrm{R}^{2}\end{array}$ & $\begin{array}{l}\text { Coeficiente de determinação }\left(\mathrm{R}^{2}\right) \text { da equação de regressão do } \\
\text { retorno da ação sobre os retornos dos fatores sistemáticos } \\
\text { definidos nos Modelo 1, Modelo } 2 \text { e Modelo 3, respectivamente. }\end{array}$ \\
\hline $\begin{array}{l}\text { IDIO_1; } \\
\text { IDIO_2 e } \\
\text { IDIO_3 }\end{array}$ & Risco idiossincrático & $\begin{array}{l}\text { Transformação logarítmica relativa o risco idiossincrático } \\
\text { calculada com base nos modelos: MODELO } 1 \text { (modelo de } \\
\text { mercado com o retorno do IBRX representando o retorno de } \\
\text { mercado); MODELO } 2 \text { (modelo incluindo o retorno do IBRX e } \\
\text { S\&P500) e MODELO } 3 \text { (CAPM), respectivamente }\end{array}$ \\
\hline CONC_P & $\begin{array}{l}\text { Concentração de } \\
\text { Propriedade: maior } \\
\text { acionista }\end{array}$ & $\begin{array}{l}\text { Transformação logarítmica da porcentagem dos direitos de } \\
\text { propriedade detidos pelo maior acionista }\end{array}$ \\
\hline CONC_3 & $\begin{array}{l}\text { Concentração de } \\
\text { Propriedade: três } \\
\text { maiores acionistas }\end{array}$ & $\begin{array}{l}\text { Transformação logarítmica da porcentagem dos direitos de } \\
\text { propriedade detidos pelos três maiores acionistas }\end{array}$ \\
\hline PEAD_1 & $\begin{array}{l}\text { Post Earnings } \\
\text { Announcement Drift } \\
\text { - janela } 1\end{array}$ & $\begin{array}{l}\text { Post Earnings Announcement Drift calculado com base na janela } \\
\text { do evento compreendida entre a véspera da divulgação dos } \\
\text { demonstrativos contábeis anuais e os dois dias posteriores }\end{array}$ \\
\hline
\end{tabular}


Tabela 3 (continuação)

\begin{tabular}{|c|c|c|}
\hline Sigla & Nome & Descrição \\
\hline PEAD_2 & $\begin{array}{l}\text { Post Earnings } \\
\text { Announcement Drift } \\
\text { - janela } 2\end{array}$ & $\begin{array}{l}\text { Post Earnings Announcement Drift calculado com base na janela } \\
\text { do evento compreendida entre a véspera da divulgação dos } \\
\text { demonstrativos contábeis anuais e os quatro dias posteriores }\end{array}$ \\
\hline OPAC & Opacidade & $\begin{array}{l}\text { Soma em módulo do valor dos accruals discricionários dos } 3 \\
\text { anos anteriores }\end{array}$ \\
\hline VM & $\begin{array}{l}\text { Valor de Mercado } \\
\text { em forma } \\
\text { logarítmica }\end{array}$ & $\begin{array}{l}\text { Logarítmo natural do valor de mercado da empresa obtido no } \\
\text { início do ano em atualizado monetariamente a valores de } 2012 \text {, } \\
\text { com base na variação do IPCA }\end{array}$ \\
\hline MMR_VM & Valor de mercado & $\begin{array}{l}\text { Valor de mercado da empresa obtido no início do ano em } \\
\text { atualizado monetariamente a valores de 2012, com base na } \\
\text { variação do IPCA e medido em milhões de reais. }\end{array}$ \\
\hline LIQ & Liquidez em Bolsa & $\begin{array}{l}\text { Medida da liquidez em bolsa obtida na base de dados } \\
\text { Economática® }\end{array}$ \\
\hline MtB & Market-to-Book & $\begin{array}{l}\text { Valor de mercado das ações dividido pelo valor e o valor } \\
\text { patrimonial da ação, medido no início do ano fiscal. }\end{array}$ \\
\hline ENDIV & Endividamento & $\begin{array}{l}\text { Dívida bruta dividida pelo patrimônio líquido, medido no início do } \\
\text { período }\end{array}$ \\
\hline RSPL & $\begin{array}{l}\text { Retorno sobre } \\
\text { Patrimônio Líquido }\end{array}$ & $\begin{array}{l}\text { Lucro líquido dividido pelo valor contábil do patrimônio líquido } \\
\text { medido no início do ano fiscal }\end{array}$ \\
\hline TURN & Turnover & $\begin{array}{l}\text { Logaritmo natural da relação entre o número de negociações das } \\
\text { ações da empresa no ano e o número de ações outstanding }\end{array}$ \\
\hline D_FIN & $\begin{array}{l}\text { Dummy setor } \\
\text { financeiro }\end{array}$ & $\begin{array}{l}\text { Dummy que assume valor } 1 \text { quando a empresa é do setor } \\
\text { financeiro, e } 0 \text { quando a empresa pertence a outro setor da } \\
\text { economia }\end{array}$ \\
\hline
\end{tabular}

Tabela que resume as variáveis, descrição e a maneira pela qual as informações foram obtidas. 


\section{ANÁLISE DOS RESULTADOS}

\subsection{Estatística descritiva}

A Tabela 4 apresenta o resumo das principais informações sobre as variáveis usadas no estudo. Em média, a capitalização de mercado das empresas analisadas é de $\mathrm{R} \$ 13,5$ bilhões, o índice Market-to-book ficou em torno de 2,7 e endividamento médio próximo a 1. As medidas: $R^{2}{ }_{1} ; R^{2} \_$e $R^{2} \_3$ referem-se às estatísticas $R^{2}$ dos modelos 1, 2 e 3 respectivamente :Equações 41 , 42 e 43 são a base para a obtenção da medida de risco idiossincrático $\left(1-\mathrm{R}^{2}\right)$.

A média dos coeficientes de determinação $\left(R^{2}\right)$ dos modelos 1,2 e 3 ficou entre 0,25 e 0,28; abaixo da média do o mercado de capital chinês (F. a. Gul et al., 2010), que ficou em torno de 0,43 e acima da média verificada por Piotroski \& Roulstone (2004) que foi de 0,193 para o mercado estadunidense. Tais observações sugerem que, comparado com as empresas listadas no mercado estadunidense, o movimento dos retornos das ações das empresas no Brasil é mais sincronizado e menos sincronizado quando se compara a média dos $\mathrm{R}^{2}$ no o ambiente chinês.

Tabela 4: Estatística descritiva das variáveis em estudo

\begin{tabular}{lrrrrr}
\hline Variável & $\begin{array}{c}\text { Número de } \\
\text { Observações }\end{array}$ & Média & \multicolumn{1}{c}{$\begin{array}{c}\text { Desvio } \\
\text { Padrão }\end{array}$} & Mínimo & Máximo \\
\hline R2_1 & 1.141 & 0,255 & 0,185 & 0,000 & 0,820 \\
R2_2 & 1.069 & 0,278 & 0,190 & 0,001 & 0,844 \\
R2_3 & 1.141 & 0,255 & 0,185 & 0,000 & 0,820 \\
IDIO_1 & 1.140 & 1,458 & 1,452 & $-1,514$ & 9,210 \\
IDIO_2 & 1.069 & 1,273 & 1,314 & $-1,688$ & 7,130 \\
IDIO_3 & 1.140 & 1,460 & 1,458 & $-1,513$ & 9,210 \\
CONC_P & 1.125 & $-0,623$ & 1,240 & $-13,816$ & 3,892 \\
CONC_3 & 1.125 & 0,205 & 1,255 & $-13,816$ & 4,595 \\
PEAD_1 & 1.052 & 0,421 & 0,383 & 0,000 & 3,878 \\
PEAD_2 & 1.052 & 0,587 & 0,579 & 0,001 & 4,627 \\
OPAC & 606 & 0,290 & 0,207 & 0,002 & 1,203 \\
VM & 1.141 & 14,917 & 1,769 & 8,530 & 19,931 \\
MMR_VM & 1.141 & 13.469 & 38.918 & 5.066 & 452.720 \\
LIQ & 1.141 & 0,666 & 1,388 & 0,000 & 13,860 \\
MtB & 1.141 & 2,690 & 3,365 & 0,004 & 20,000 \\
ENDIV & 1.045 & 1,161 & 3,561 & 0,000 & 62,872 \\
RSPL & 992 & 0,354 & 4,100 & 0,000 & 128,963 \\
TURN & 1.141 & 0,956 & 3,467 & 0,000 & 91,466 \\
\hline
\end{tabular}


Tabela 5: Correlacão de Pearson

\begin{tabular}{|c|c|c|c|c|c|c|c|c|c|c|c|c|c|c|c|c|c|c|c|c|c|c|c|c|}
\hline & & 1 & & 2 & & 3 & & 4 & & 5 & & 6 & & 7 & & 8 & 9 & 10 & 11 & & 12 & & 13 & 14 \\
\hline 1 & IDIO_1 & 1,00 & & & & & & & & & & & & & & & & & & & & & & \\
\hline 2 & IDIO_2 & 0,88 & $* * *$ & 1,00 & & & & & & & & & & & & & & & & & & & & \\
\hline 3 & IDIO_3 & 1,00 & $* * *$ & 0,88 & $* * *$ & 1,00 & & & & & & & & & & & & & & & & & & \\
\hline 4 & LIQ & $-0,40$ & $* * *$ & $-0,43$ & $* * *$ & $-0,40$ & $* * *$ & 1,00 & & & & & & & & & & & & & & & & \\
\hline 5 & VM & $-0,46$ & $* * *$ & $-0,48$ & $* * *$ & $-0,46$ & $* \star *$ & 0,57 & $* \star *$ & 1,00 & & & & & & & & & & & & & & \\
\hline 6 & CONC_P & 0,18 & $* * *$ & 0,15 & $* * *$ & 0,18 & $* * *$ & $-0,13$ & $* * *$ & 0,02 & & 1,00 & & & & & & & & & & & & \\
\hline 7 & CONC_3 & 0,22 & $* * *$ & 0,20 & $* * *$ & 0,22 & $* \star *$ & $-0,24$ & $* \star *$ & $-0,01$ & & 0,90 & $* * *$ & 1,00 & & & & & & & & & & \\
\hline 8 & PEAD_1 & 0,00 & & 0,00 & & 0,00 & & $-0,03$ & & 0,00 & & 0,03 & & 0,02 & & 1,00 & & & & & & & & \\
\hline 9 & PEAD_2 & $-0,02$ & & $-0,01$ & & $-0,02$ & & $-0,01$ & & $-0,01$ & & 0,02 & & 0,01 & & $0,92 * * *$ & 1,00 & & & & & & & \\
\hline 10 & OPAC & $-0,01$ & & 0,03 & & $-0,02$ & & $-0,01$ & & $-0,11$ & $* * *$ & 0,00 & & $-0,06$ & & $-0,02$ & 0,02 & 1,00 & & & & & & \\
\hline 11 & TURN & $-0,15$ & $* * *$ & $-0,11$ & $* * *$ & $-0,15$ & $* * *$ & 0,08 & $* * *$ & 0,11 & $* * *$ & $-0,26$ & $* * *$ & $-0,27$ & $* * *$ & $-0,03$ & $-0,03$ & $-0,17 \quad * * *$ & 1,00 & & & & & \\
\hline 12 & $\mathrm{MtB}$ & 0,00 & & 0,03 & & 0,00 & & 0,02 & & 0,19 & $* * *$ & $-0,04$ & & $-0,03$ & & $-0,02$ & $-0,02$ & $-0,06$ & 0,13 & $* * *$ & 1,00 & & & \\
\hline 13 & ENDIV & $-0,01$ & & 0,00 & & $-0,01$ & & $-0,03$ & & $-0,06$ & $* *$ & $-0,02$ & & $-0,01$ & & 0,00 & 0,00 & 0,04 & $-0,08$ & ** & 0,35 & $* * *$ & 1,00 & \\
\hline 14 & RSPL & 0,02 & & 0,05 & & 0,02 & & $-0,01$ & & $-0,06$ & $* *$ & $-0,05$ & * & $-0,06$ & * & $-0,02$ & $-0,01$ & 0,01 & $-0,06$ & * & 0,19 & $* * *$ & $0,11 * * *$ & 1,00 \\
\hline
\end{tabular}

Os valores correspondem à correlação de Pearson entre as variáveis utilizadas no estudo. Os sinais: *, ${ }^{* *}$ e ${ }^{* * *}$ correspondem os níveis de significância $10 \% ; 5 \%$ e $1 \%$ respectivamente. A Tabela 3 contém a descrição das variáveis constantes desta tabela. 
A Tabela 5 mostra a correlação entre variáveis utilizadas no estudo. Como se pode observar, as medidas do risco idiossincrático obtidas pelos modelos 1, 2 e 3 são altamente correlacionadas (correlação 0,88 e 0,9999).

Consistente com a hipótese de que a concentração de propriedade afeta o risco idiossincrático, observa-se, pela Tabela 5 , que a correlação entre o risco idiossincrático e a participação acionária do maior acionista e dos três maiores acionistas é significante (valor-p $<0,01$ ), sugerindo que os incentivos aos investidores para monitorar a gestão contribuem para a incorporação de informações específicas nos preços e, consequentemente o risco idiossincrático aumenta.

O risco idiossincrático se mostrou negativamente relacionado com o porte da empresa, compatível com a observação de que as grandes empresas são potencialmente mais diversificadas e atuam em vários setores da economia. Isso justifica, em parte, porque as ações das grandes empresas em geral são aquelas com menor risco idiossincrático quando comparadas com as pequenas empresas.

Empresas com maior visibilidade e mais negociadas teriam a tendência de incorporar nos preços, tanto as informações específicas quanto aquelas que que refletem o movimento da economia. É razoável esperar que a correlação negativa entre a liquidez em bolsa e o turnover como observada.

Cumpre mencionar que as características específicas das empresas relacionadas à gestão como: 1) Oportunidade de crescimento (Market-to-book); 2) Endividamento e 3) Retorno sobre o patrimônio líquido não se mostraram significativamente correlacionadas com as medidas do risco idiossincrático entre as empresas analisadas. Alie-se isso à observação de que também as métricas que avaliam a opacidade (transparência) corporativa não se mostraram significativamente correlacionadas (valor- $p>0,10$ ). Isso sugere que a tendência dos retornos se moverem em sincronia com o mercado não está relacionada às informações divulgadas acerca do desempenho da empresa. 
Vale assinalar que as empresas produzem e divulgam informações de maneira diferente para cada público, o que torna desafiador uma medida que capture as percepções dos diversos atores que utilizam a informação para a tomada de decisão econômica. As medidas usadas na literatura para estimar o grau de opacidade corporativa podem não capturar com fidedignidade a percepção conjunta do investidor acerca do desempenho futuro da empresa.

Ao analisar a concentração de propriedade das empresas que compõe a amostra em estudo observa-se que, em média, o maior acionista detém 37\% dos direitos de propriedade enquanto os três maiores acionistas respondem por $53 \%$ do total das ações (Tabela 6). A Tabela 7 e a Tabela 8 detalham, respectivamente, o percentual dos direitos de propriedade detidos pelo maior acionista e pelos três maiores acionistas ao longo do período analisado.

Tabela 6: Estatística descritiva de informações sobre concentração acionária

\begin{tabular}{|c|c|c|c|c|c|}
\hline Informação & $\begin{array}{l}\text { Número de } \\
\text { observações }\end{array}$ & Média & $\begin{array}{l}\text { Desvio } \\
\text { Padrão }\end{array}$ & Mínimo & Máximo \\
\hline $\begin{array}{l}\text { Participação do maior } \\
\text { acionista (\%) }\end{array}$ & 1.141 & 36,9 & 20,6 & 0,0 & 98,0 \\
\hline $\begin{array}{l}\text { Participação dos três } \\
\text { maiores acionistas (\%) }\end{array}$ & 1.141 & 53,5 & 21,1 & 0,0 & 99,0 \\
\hline
\end{tabular}

A coluna Mínimo refere-se ao menor percentual detido pelo maior acionista (três maiores acionistas) na amostra. O valor zero significa que em pelo menos um caso, nenhum acionista detém participação acionária acima de $5 \%$, percentual a partir do qual o acionista é identificado. A coluna Máximo refere-se ao maior percentual detido pelo maior acionista (três maiores acionistas) na amostra. O valor máximo indicado: 98 (99) significa que pelo menos em uma empresa, o maior acionista (três maiores acionistas) detém 98\% (99\%) das ações.

Pela Figura 2 observa-se a distribuição das frequências relativas das participações acionárias do maior acionista, constatando-se que a concentração acionária tem distribuição ligeiramente assimétrica à esquerda. 

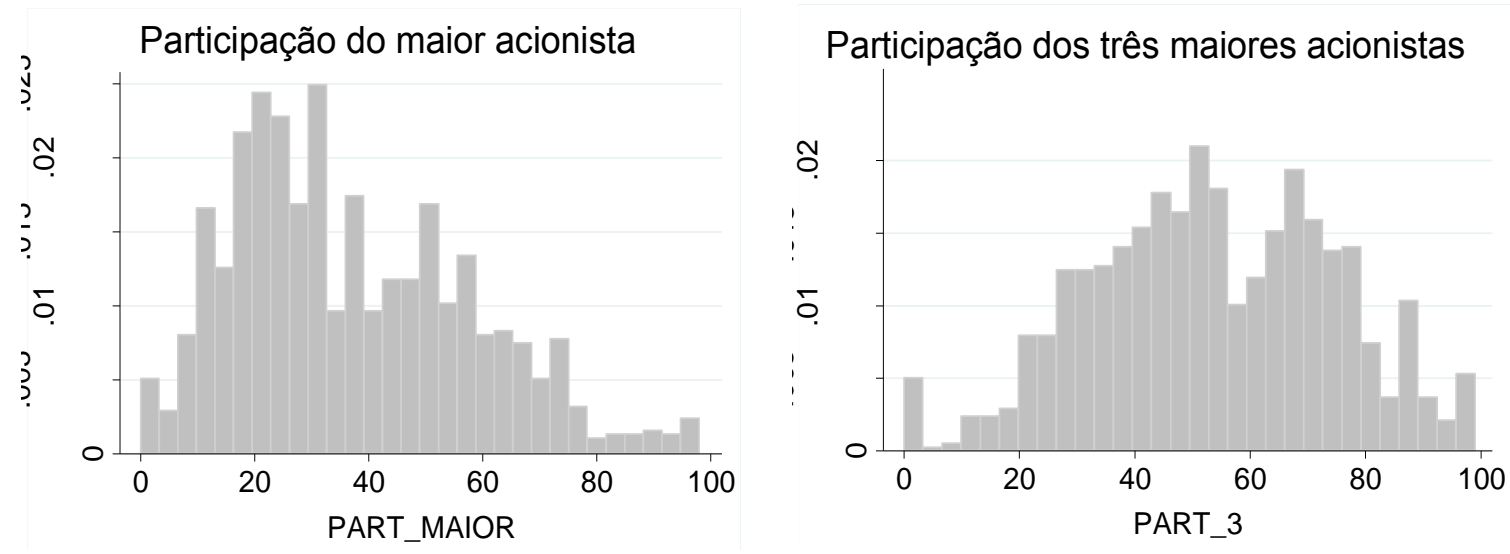

Figura 2: Distribuição de frequência das participações do maior acionista e dos três maiores acionistas das empresas analisadas nos anos de 2002 a 2012

Com base nas informações da Tabela 7 e da Tabela 8, verifica-se que a média e a mediana dos direitos de propriedade ficam em torno de $30 \%$ e $50 \%$ para o maior acionista e os três maiores, respectivamente, ilustrando a alta concentração dos direitos de propriedade na amostra e no período analisado.

Tabela 7: Percentual dos direitos de propriedade detidos pelo maior acionista que detém pelo menos $5 \%$ do capital total

\begin{tabular}{rrrrrrrr}
\hline \multicolumn{1}{l}{ Ano } & $\begin{array}{c}\text { Número de } \\
\text { observações }\end{array}$ & Mínimo & 10 Quartil & Mediana & 3o Quartil & Máximo & Média \\
\hline 2.002 & 75 & 0,0 & 20,0 & 32,0 & 51,0 & 95,0 & 37,8 \\
2.003 & 68 & 5,0 & 21,3 & 36,5 & 54,0 & 94,0 & 39,2 \\
2.004 & 69 & 5,0 & 20,0 & 34,0 & 52,0 & 97,0 & 38,0 \\
2.005 & 88 & 0,0 & 21,0 & 34,5 & 51,5 & 97,0 & 38,6 \\
2.006 & 68 & 0,0 & 20,0 & 31,5 & 47,8 & 90,0 & 37,0 \\
2.007 & 80 & 0,0 & 20,0 & 32,0 & 50,0 & 98,0 & 36,2 \\
2.008 & 105 & 7,0 & 21,0 & 37,0 & 53,0 & 92,0 & 39,8 \\
2.009 & 131 & 0,0 & 21,0 & 32,0 & 53,0 & 90,0 & 36,9 \\
2.010 & 153 & 0,0 & 21,0 & 32,0 & 52,5 & 98,0 & 36,3 \\
2.011 & 157 & 0,0 & 20,0 & 31,0 & 53,0 & 98,0 & 36,1 \\
2.012 & 147 & 5,0 & 19,0 & 30,0 & 48,0 & 98,0 & 33,8 \\
GERAL & 1.141 & 0,0 & 20,0 & 32,0 & 52,0 & 98,0 & 36,9 \\
\hline A COU,
\end{tabular}

A coluna Mínimo refere-se ao menor percentual detido pelo maior acionista na amostra. $O$ valor zero significa que em pelo menos um caso, nenhum acionista detém participação acionária acima de $5 \%$, percentual a partir do qual o acionista é identificado. A coluna Máximo refere-se ao maior percentual detido pelo maior acionista (três maiores acionistas) na amostra. O valor máximo indicado: 98 significa que pelo menos em uma empresa, o maior acionista detém $98 \%$ das ações. 
Tabela 8: Percentual dos direitos de propriedade detidos pelos três maiores acionistas que, individualmente detém pelo menos $5 \%$ do capital total.

\begin{tabular}{crrrrrrr}
\hline \multicolumn{1}{l}{ Ano } & $\begin{array}{c}\text { Número de } \\
\text { observações }\end{array}$ & Mínimo & 10 Quartil & Mediana & 3ํ Quartil & Máximo & Média \\
\hline 2.002 & 75 & 0,0 & 34,0 & 50,0 & 68,0 & 95,0 & 51,4 \\
2.003 & 68 & 12,0 & 32,8 & 50,0 & 70,0 & 94,0 & 52,2 \\
2.004 & 69 & 12,0 & 32,5 & 50,0 & 72,0 & 98,0 & 52,9 \\
2.005 & 88 & 0,0 & 36,5 & 51,3 & 71,0 & 98,0 & 52,8 \\
2.006 & 68 & 0,0 & 37,3 & 53,0 & 68,8 & 94,0 & 53,3 \\
2.007 & 80 & 0,0 & 38,0 & 52,0 & 69,0 & 98,0 & 52,7 \\
2.008 & 105 & 19,0 & 40,0 & 57,0 & 74,6 & 99,0 & 58,7 \\
2.009 & 131 & 0,0 & 42,0 & 53,0 & 70,0 & 99,0 & 54,2 \\
2.010 & 153 & 0,0 & 38,0 & 53,0 & 68,5 & 98,0 & 52,5 \\
2.011 & 157 & 0,0 & 38,0 & 54,0 & 67,5 & 98,0 & 53,6 \\
2.012 & 147 & 5,0 & 39,0 & 52,0 & 68,0 & 99,0 & 52,8 \\
GERAL & 1.141 & 0,0 & 38,0 & 52,0 & 70,0 & 99,0 & 53,5 \\
\hline
\end{tabular}

A coluna Mínimo refere-se ao menor percentual detido pelos três maiores acionistas na amostra. O valor zero significa que em pelo menos um caso, nenhum acionista detém participação acionária acima de $5 \%$, percentual a partir do qual o acionista é identificado. A coluna Máximo refere-se ao maior percentual detido pelos três maiores acionistas na amostra. O valor máximo indicado: 99 significa que pelo menos em uma empresa, os três maiores acionistas detém $99 \%$ das ações.

\subsection{Análise multivariada da relação entre o risco idiossincrático e concentração de propriedade e análise da interação entre concentração de propriedade e transparência corporativa}

Inicialmente foi avaliada a associação entre a concentração de propriedade e o risco idiossincrático e o impacto da dependência entre concentração de propriedade (CONC_P e CONC_3) e a transparência corporativa (PEAD_1 e OPAC).

A Tabela 9 apresenta os resultados das regressões multivariadas para as equações 59 e 60 e a Tabela 10 para as equações 61 e 62. Os valores da estatística t reportados foram ajustados à heterocedasticidade (erros robustos) após a presença ter sido identificada pelo teste de Breusch-Pagan/CookWeisberg. A concentração de propriedade, medida pelas variáveis CONC_P e CONC_3, mostrou-se positivamente significante (valor- $p<0,01$ ), na presença das outras variáveis.

O coeficiente da variável quadrática (CONC_3 $)^{2}$ mostrou-se positivamente significante $($ valor- $p<0,01)$ para os modelos em que a análise abrangeu 0 
período compreendido entre 2002 e $2012^{41}$. Isso indica que no período analisado, o risco idiossincrático é uma função convexa da concentração de propriedade. Um aumento na concentração de propriedade potencializa a variação do risco idiossincrático .

É razoável argumentar, entretanto, que o aumento na concentração de propriedade possa um produzir um impacto amplificado sobre o risco idiossincrático das empresas com maior opacidade. Para avaliar tal situação foi analisado o efeito da interação entre concentração de propriedade e transparência corporativa: $C O N C_{-} P_{i, a} \times P E A D_{-} 1_{i, a}$ e $C O N C_{-} P_{i, a} \times O P A C_{i, a}$. Porém, os coeficientes foram não-significativos, sugerindo que a concentração de propriedade e a opacidade não têm efeito conjunto sobre o risco idiossincrático.

Além disso, não foram encontradas evidências de que a opacidade corporativa tenha efeito sobre o risco idiossincrático para o mercado brasileiro. Verificouse que os coeficientes das variáveis proxy de não-transparência (OPAC e PEAD_1) foram não significativos

$$
\begin{aligned}
& I D I O \_1_{i, a}=\alpha+\beta_{1} C O N C_{-} P_{i, a}+\beta_{2}\left(C O N C_{-} P_{i, a}\right)^{2}+\beta_{3} P E A D \_1_{i, a} \\
& +\beta_{4} \text { CONC_ } 3_{i, a} \times P E A D_{-} 1_{i, a}+\beta_{5} O P A C_{i, a}+\beta_{6} C O N C_{-} P_{i, a} \times O P A C_{i, a} \\
& +\beta_{7} V M_{i, a}+\beta_{8} L I Q_{i, a}+\beta_{9}\left(L I Q_{i, a}\right)^{2}+\beta_{10} R S P L_{i, a}+\beta_{11} E N D I V_{i, a} \\
& +\beta_{12} M t B_{i, a}+\beta_{13} \operatorname{TURN}_{i, a}+\beta_{14} D_{-} F I N_{i, a}+\varepsilon_{i, a} \\
& I D I O \_2_{i, a}=\alpha+\beta_{1} \text { CONC_P } P_{i, a}+\beta_{2}\left(C O N C_{-} P_{i, a}\right)^{2}+\beta_{3} P E A D_{-} 1_{i, a} \\
& +\beta_{4} \text { CONC_ } P_{i, a} \times P E A D_{-} 1_{i, a}+\beta_{5} O P A C_{i, a}+\beta_{6} C O N C_{-} P_{i, a} \times O P A C_{i, a} \\
& +\beta_{7} V M_{i, a}+\beta_{8} L I Q_{i, a}+\beta_{9}\left(L I Q_{i, a}\right)^{2}+\beta_{10} R S P L_{i, a}+\beta_{11} E N D I V_{i, a} \\
& +\beta_{12} M t B_{i, a}+\beta_{13} \operatorname{TURN}_{i, a}+\beta_{14} D_{-} \text {IIN }_{i, a}+\varepsilon_{i, a}
\end{aligned}
$$

${ }^{41}$ Vale lembrar que nos modelos em que a variável OPAC representa a opacidade corporativa, a análise abrange o período 2002 a 2010. Isso porque, conforme já relatado, a mudança do padrão contábil implementada em 2010 impossibilitou a construção da variável OPAC para os anos de 2011 e 2012. 
Tabela 9: Efeito da concentração de propriedade (maior acionista) e da transparência corporativa sobre o risco idiossincrático.

\begin{tabular}{|c|c|c|c|c|c|c|c|c|c|c|c|c|}
\hline Equação & \multicolumn{2}{|l|}{59} & \multicolumn{2}{|l|}{59} & \multicolumn{2}{|l|}{59} & \multicolumn{2}{|l|}{60} & \multicolumn{2}{|c|}{60} & \multicolumn{2}{|c|}{60} \\
\hline Variável & IDIO_ & & $I D I O$ & & $I D I O$ & & $I D I O$ & & $I D I O$ & & $I D I O$ & \\
\hline Intercepto & $\begin{array}{r}5,473 \\
(13,23)\end{array}$ & $* * *$ & $\begin{array}{r}5,184 \\
(9,61)\end{array}$ & $* * *$ & $\begin{array}{r}5,259 \\
(15,08)\end{array}$ & $* * *$ & $\begin{array}{r}5,905 \\
(14,39)\end{array}$ & $* * *$ & $\begin{array}{r}5,593 \\
(15,28)\end{array}$ & $* \star *$ & $\begin{array}{r}5,726 \\
(10,61)\end{array}$ & $* * *$ \\
\hline CONC_P & $\begin{array}{r}0,217 \\
(4,92)\end{array}$ & $* \star *$ & $\begin{array}{r}0,270 \\
(3,33)\end{array}$ & $* \star *$ & $\begin{array}{r}0,147 \\
(2,95)\end{array}$ & $* \star *$ & $\begin{array}{r}0,234 \\
(4,78)\end{array}$ & $* * *$ & $\begin{array}{r}0,200 \\
(4,49)\end{array}$ & $* * *$ & $\begin{array}{r}0,334 \\
(3,31)\end{array}$ & $* * *$ \\
\hline$(\mathrm{CONC} P)^{2}$ & $\begin{array}{r}0,017 \\
(3,75)\end{array}$ & $* * *$ & $\begin{array}{r}0,036 \\
(1,35)\end{array}$ & & $\begin{array}{r}0,007 \\
(1,69)\end{array}$ & * & $\begin{array}{r}0,015 \\
(3,1)\end{array}$ & $* * *$ & $\begin{array}{r}0,011 \\
(2,96)\end{array}$ & $* * *$ & $\begin{array}{r}0,041 \\
(1,08)\end{array}$ & \\
\hline PEAD_1 & $\begin{array}{r}0,006 \\
(0,19)\end{array}$ & & & & $\begin{array}{r}0,038 \\
(0,75)\end{array}$ & & $\begin{array}{r}-0,002 \\
(-0,06)\end{array}$ & & $\begin{array}{r}-0,010 \\
(-0,26)\end{array}$ & & & \\
\hline CONC_PXPEAD_1 & $\begin{array}{r}0,052 \\
(1,27)\end{array}$ & & & & $\begin{array}{r}0,109 \\
(1,58)\end{array}$ & & $\begin{array}{r}0,025 \\
(0,56)\end{array}$ & & $\begin{array}{r}0,018 \\
(0,38)\end{array}$ & & & \\
\hline OPAC & & & $\begin{array}{r}-0,489 \\
(-1,93)\end{array}$ & * & & & & & & & $\begin{array}{l}-0,253 \\
(-0,84)\end{array}$ & \\
\hline CONC_PxOPAC & & & $\begin{array}{r}-0,203 \\
(-0,96)\end{array}$ & & & & & & & & $\begin{array}{r}-0,240 \\
(-1,05)\end{array}$ & \\
\hline VM & $\begin{array}{r}-0,269 \\
(-9,48)\end{array}$ & $* * *$ & $\begin{array}{r}-0,234 \\
(-6,41)\end{array}$ & $* * *$ & $\begin{array}{l}-0,256 \\
(-10,65)\end{array}$ & $* * *$ & $\begin{array}{l}-0,301 \\
(-10,91)\end{array}$ & $* * *$ & $\begin{array}{l}-0,281 \\
(-11,36)\end{array}$ & $* * *$ & $\begin{array}{r}-0,280 \\
(-7,95)\end{array}$ & $* * *$ \\
\hline LIQ & $\begin{array}{r}-0,178 \\
(-6,67)\end{array}$ & $* * *$ & $\begin{array}{r}-0,173 \\
(-7,00)\end{array}$ & $\star \star \star *$ & $\begin{array}{r}-0,185 \\
(-7,49)\end{array}$ & $* * *$ & $\begin{array}{r}-0,151 \\
(-6,31)\end{array}$ & $* * *$ & $\begin{array}{r}-0,166 \\
(-6,89)\end{array}$ & $* * *$ & $\begin{array}{r}-0,149 \\
(-6,51)\end{array}$ & $* * *$ \\
\hline RSPL & $\begin{array}{r}-0,005 \\
(-2,2)\end{array}$ & ** & $\begin{array}{r}-0,001 \\
(-0,50)\end{array}$ & & & & $\begin{array}{r}0,004 \\
(1,96)\end{array}$ & * & & & $\begin{array}{r}0,005 \\
(1,63)\end{array}$ & \\
\hline ENDIV & $\begin{array}{r}-0,038 \\
(-2,15)\end{array}$ & ** & $\begin{array}{r}-0,031 \\
(-1,81)\end{array}$ & * & & & $\begin{array}{r}-0,037 \\
(-2,54)\end{array}$ & ** & & & $\begin{array}{r}-0,035 \\
(-2,67)\end{array}$ & $* * *$ \\
\hline MtB & $\begin{array}{r}0,055 \\
(4,77)\end{array}$ & $* * *$ & $\begin{array}{r}0,028 \\
(1,57)\end{array}$ & & $\begin{array}{r}0,035 \\
(3,46)\end{array}$ & $* * *$ & $\begin{array}{r}0,044 \\
(3,88)\end{array}$ & $* * *$ & $\begin{array}{r}0,028 \\
(2,87)\end{array}$ & $* * *$ & $\begin{array}{r}0,036 \\
(2,03)\end{array}$ & ** \\
\hline TURN & $\begin{array}{r}-0,042 \\
(-3,22)\end{array}$ & $* * *$ & $\begin{array}{r}-0,024 \\
(-1,83)\end{array}$ & * & $\begin{array}{r}-0,042 \\
(-3,41)\end{array}$ & $* * *$ & $\begin{array}{r}-0,011 \\
(-0,93)\end{array}$ & & $\begin{array}{r}-0,015 \\
(-1,36)\end{array}$ & & $\begin{array}{r}-0,001 \\
(-0,04)\end{array}$ & \\
\hline D_FIN & & & & & $\begin{array}{r}-0,479 \\
(-4,47)\end{array}$ & $* * *$ & & & $\begin{array}{r}-0,408 \\
(-3,87)\end{array}$ & $* * *$ & & \\
\hline$N$ & 893 & & 558 & & 1.024 & & 843 & & 970 & & 534 & \\
\hline$R 2$ & 0,2856 & & 0,3094 & & 0,3174 & & 0,3031 & & 0,3374 & & 0,3389 & \\
\hline
\end{tabular}

Os números entre parêntesis correspondem à estatística $t$ ajustada para correção de heterocedasticidade. D_FIN é a variável dummy que assume valor 1 para empresas do setor financeiro e 0 para as demais empresas. Foram excluídas as observações que geraram resíduos discrepantes. Os sinais: * ${ }^{* *} \mathrm{e}^{* * *}$ correspondem os níveis de significância $10 \% ; 5 \%$ e $1 \%$ respectivamente. As variáveis utilizadas estão descritas na Tabela 3. Os resultados das regressões utilizando a métrica IDIO_3 foram omitidas tendo em vista que os resultados foram quase idênticos àqueles obtidos com a medida IDIO_1. Foram omitidos os resultados da regressão com a variável PEAD_2 pois os resultados levavam às mesmas conclusões daqueles que foram apresentados com a variável PEAD_1.

Volta-se a análise para as variáveis de controle. Os coeficientes das variáveis VM e LIQ foram positivamente significantes (valor-p<0,01). Isso sugere que 0 preço das ações das grandes empresas tendem a espelhar o comportamento do mercado (Chan \& Hameed, 2006). Já para as ações que não são ativamente negociadas o risco idiossincrático espelha, em parte, o risco de liquidez 
(Spiegel \& Wang, 2005). Além disso, a possibilidade de grandes quantidades de ações poderem ser negociadas a baixo custo sem que grandes mudanças no preço sejam implementadas é uma outra explicação para relação negativa entre liquidez e risco idiossincrático (Bali et al., 2005). A variável MtB foi, na presença das demais variáveis, positivamente significante na maioria dos modelos (valor-p $<0,05$ ), sugerindo que ações de empresas com maior potencial de crescimento também são aquelas que têm mais informações específicas incorporadas aos preços. O coeficiente da variável dummy que distingui as empresas do setor financeiro foi negativamente significante (valor- $p<0,01$ ), indicando que o risco idiossincrático das empresas do setor financeiro são, em média, menores do que as demais, tudo o mais permanecendo constante. Os outros coeficientes estimados não se mostraram significantes de maneira consistente.

$$
\begin{aligned}
& I D I O{ }_{-} 1_{i, a}=\alpha+\beta_{1} C O N C_{-} 3_{i, a}+\beta_{2}\left(C O N C_{-} 3_{i, a}\right)^{2}+\beta_{3} P E A D_{-} 1_{i, a} \\
& +\beta_{4} \text { CONC_P }_{i, a} \times P E A D_{-} 1_{i, a}+\beta_{5} O P A C_{i, a}+\beta_{6} \text { CONC_ }_{-} P_{i, a} \times O P A C_{i, a} \\
& +\beta_{7} V M_{i, a}+\beta_{8} L I Q_{i, a}+\beta_{9}\left(L I Q_{i, a}\right)^{2}+\beta_{10} R_{S P L i, a}+\beta_{11} E N D I V_{i, a} \\
& +\beta_{12} M t B_{i, a}+\beta_{13} \text { TURN }_{i, a}+\beta_{14} D_{-} F I N_{i, a}+\varepsilon_{i, a} \\
& I D I O \_2_{i, a}=\alpha+\beta_{1} C O N C_{-} 3_{i, a}+\beta_{2}\left(C O N C_{-} 3_{i, a}\right)^{2}+\beta_{3} P E A D_{-} 1_{i, a} \\
& +\beta_{4} \text { CONC_- }_{i, a} \times P E A D_{-} 1_{i, a}+\beta_{5} O P A C_{i, a}+\beta_{6} \operatorname{CONC}_{-} 3_{i, a} \times O P A C_{i, a} \\
& +\beta_{7} V M_{i, a}+\beta_{8} L I Q_{i, a}+\beta_{9}\left(L I Q_{i, a}\right)^{2}+\beta_{10} R S P L_{i, a}+\beta_{11} E N D I V_{i, a} \\
& +\beta_{12} M t B_{i, a}+\beta_{13} \text { TURN }_{i, a}+\beta_{14} D_{-} F I N_{i, a}+\varepsilon_{i, a}
\end{aligned}
$$


Tabela 10: Efeito da concentração de propriedade (maior acionista) e da transparência corporativa sobre o risco idiossincrático.

\begin{tabular}{|c|c|c|c|c|c|c|c|c|c|c|c|c|}
\hline Equação & \multicolumn{2}{|l|}{61} & \multicolumn{2}{|l|}{61} & \multicolumn{2}{|l|}{61} & \multicolumn{2}{|l|}{62} & \multicolumn{2}{|l|}{62} & \multicolumn{2}{|l|}{62} \\
\hline Variável & IDIO_1 & & IDIO_ & & IDIO_ & & IDIO_ & & $I D I O_{-}$ & & IDIO_ & \\
\hline Intercepto & $\begin{array}{r}5,298 \\
(13,06)\end{array}$ & $* * *$ & $\begin{array}{c}5,176 \\
(14,95)\end{array}$ & *** & $\begin{array}{r}5,025 \\
(8,97)\end{array}$ & $* * *$ & $\begin{array}{c}5,761 \\
(14,23)\end{array}$ & $* * *$ & $\begin{array}{c}5,534 \\
(15,44)\end{array}$ & $\star \star \star *$ & $\begin{array}{c}5,449 \\
(10,36)\end{array}$ & $* * *$ \\
\hline CONC_3 & $\begin{array}{r}0,252 \\
(5,38)\end{array}$ & $* * *$ & $\begin{array}{c}0,224 \\
(4,03)\end{array}$ & *** & $\begin{array}{r}0,316 \\
(3,45)\end{array}$ & $* * *$ & $\begin{array}{r}0,215 \\
(4,88)\end{array}$ & $* * *$ & $\begin{array}{r}0,211 \\
(5,18)\end{array}$ & *** & $\begin{array}{r}0,324 \\
(3,52)\end{array}$ & $* * *$ \\
\hline$\left(\mathrm{CONC} \_3\right)^{2}$ & $\begin{array}{r}0,019 \\
(4,26)\end{array}$ & $* * *$ & $\begin{array}{r}0,013 \\
(2,87)\end{array}$ & $* * *$ & $\begin{array}{r}-0,030 \\
(-1,12)\end{array}$ & & $\begin{array}{r}0,012 \\
(2,97)\end{array}$ & $* \star *$ & $\begin{array}{r}0,011 \\
(3,37)\end{array}$ & $\star \star *$ & $\begin{array}{r}-0,035 \\
(-1,18)\end{array}$ & \\
\hline PEAD_1 & $\begin{array}{r}-0,039 \\
(-2,35)\end{array}$ & ** & $\begin{array}{r}-0,057 \\
(-2,12)\end{array}$ & ** & & & $\begin{array}{r}-0,019 \\
(-0,85)\end{array}$ & & $\begin{array}{r}-0,020 \\
(-0,94)\end{array}$ & & & \\
\hline CONC_PxPEAD_1 & $\begin{array}{r}0,028 \\
(0,65)\end{array}$ & & $\begin{array}{r}0,067 \\
(0,76)\end{array}$ & & & & $\begin{array}{l}0,000 \\
(-0,01)\end{array}$ & & $\begin{array}{r}0,001 \\
(0,02)\end{array}$ & & & \\
\hline OPAC & & & & & $\begin{array}{l}-0,187 \\
(-0,91)\end{array}$ & & & & & & $\begin{array}{l}0,039 \\
(0,18)\end{array}$ & \\
\hline CONC_PXOPAC & & & & & $\begin{array}{r}-0,227 \\
(-1,00)\end{array}$ & & & & & & $\begin{array}{c}-0,288 \\
(-1,21)\end{array}$ & \\
\hline VM & $\begin{array}{r}-0,270 \\
(-9,68)\end{array}$ & $* * *$ & $\begin{array}{l}-0,259 \\
(-10,88)\end{array}$ & $\star \star \star *$ & $\begin{array}{r}-0,236 \\
(-6,17)\end{array}$ & $* * *$ & $\begin{array}{l}-0,305 \\
(-11,10)\end{array}$ & $* * *$ & $\begin{array}{l}-0,290 \\
(-11,80)\end{array}$ & $* * *$ & $\begin{array}{r}-0,277 \\
(-7,85)\end{array}$ & $* * *$ \\
\hline LIQ & $\begin{array}{r}-0,149 \\
(-5,80)\end{array}$ & $* * *$ & $\begin{array}{r}-0,155 \\
(-6,34)\end{array}$ & *** & $\begin{array}{r}-0,158 \\
(-6,10)\end{array}$ & $* * *$ & $\begin{array}{r}-0,130 \\
(-5,51)\end{array}$ & $* * *$ & $\begin{array}{r}-0,139 \\
(-5,88)\end{array}$ & *** & $\begin{array}{r}-0,138 \\
(-5,87)\end{array}$ & $* * *$ \\
\hline RSPL & $\begin{array}{r}-0,003 \\
(-1,35)\end{array}$ & & & & $\begin{array}{r}0,002 \\
(0,57)\end{array}$ & & $\begin{array}{r}0,004 \\
(2,09)\end{array}$ & ** & & & $\begin{array}{r}0,007 \\
(2,40)\end{array}$ & ** \\
\hline ENDIV & $\begin{array}{r}-0,035 \\
(-2,02)\end{array}$ & ** & & & $\begin{array}{r}-0,022 \\
(-1,36)\end{array}$ & & $\begin{array}{r}-0,037 \\
(-2,49)\end{array}$ & ** & & & $\begin{array}{r}-0,030 \\
(-2,11)\end{array}$ & ** \\
\hline MtB & $\begin{array}{r}0,053 \\
(4,59)\end{array}$ & $* * *$ & $\begin{array}{r}0,035 \\
(3,46)\end{array}$ & $* * *$ & $\begin{array}{r}0,028 \\
(1,54)\end{array}$ & & $\begin{array}{r}0,044 \\
(3,85)\end{array}$ & $* * *$ & $\begin{array}{r}0,029 \\
(2,90)\end{array}$ & *** & $\begin{array}{r}0,038 \\
(2,06)\end{array}$ & ** \\
\hline TURN & $\begin{array}{r}-0,031 \\
(-2,48)\end{array}$ & ** & $\begin{array}{r}-0,030 \\
(-2,57)\end{array}$ & ** & $\begin{array}{r}-0,018 \\
(-1,41)\end{array}$ & & $\begin{array}{r}-0,010 \\
(-0,84)\end{array}$ & & $\begin{array}{r}-0,012 \\
(-1,04)\end{array}$ & & $\begin{array}{l}0,000 \\
(-0,01)\end{array}$ & \\
\hline D_FIN & & & $\begin{array}{r}-0,496 \\
(-4,66)\end{array}$ & $* * *$ & & & & & $\begin{array}{r}-0,384 \\
(-3,74)\end{array}$ & $* \star *$ & & \\
\hline $\mathrm{N}$ & 893 & & 1.024 & & 560 & & 842 & & 968 & & 534 & \\
\hline$R 2$ & 0,2937 & & 0,3291 & & 0,3047 & & 0,3027 & & 0,3447 & & 0,3303 & \\
\hline
\end{tabular}

Os números entre parêntesis correspondem à estatística $\mathrm{t}$ ajustada para correção de heterocedasticidade, D_FIN é a variável dummy que assume valor 1 para empresas do setor financeiro e 0 para as demais empresas. Foram excluídas as observações que geraram resíduos discrepantes. Os sinais: * ${ }^{* *} e^{* * *}$ correspondem os níveis de significância $10 \% ; 5 \%$ e $1 \%$ respectivamente. As variáveis utilizadas estão descritas na Tabela 3. Os resultados das regressões utilizando a métrica IDIO_3 foram omitidas tendo em vista que os resultados foram quase idênticos àqueles obtidos com a medida IDIO_1. Foram omitidos os resultados da regressão com a variável PEAD_2 pois os resultados levavam às mesmas conclusões daqueles que foram apresentados com a variável PEAD_1. 


\subsection{Concentração de propriedade e risco idiossincrático}

Para avaliar o impacto da concentração de propriedade sobre o risco idiossincrático, foram usadas duas abordagens: concentração de propriedade medida pela participação do maior acionista e concentração de propriedade medida pela participação conjunta dos três maiores acionistas.

Nas duas abordagens, dividiu-se a amostra em dois grupos. Quando o foco foi lançado sobre o maior acionista, o primeiro grupo correspondeu à subamostra das empresas em que o maior acionista detém mais de $50 \%$ dos direitos de propriedade e o outro referiu-se à subamostra das empresas em que o principal acionista detém $50 \%$ ou menos dos direitos de propriedade. Aproximadamente $50 \%$ é a participação acionária de Q3 (terceiro quartil).

Gul, Kim e Qiu (2010) observaram naquele estudo que a sincronicidade tinha um pico quando a concentração acionária atingia 50\%. A partir desse nível de concentração o aumento na participação do maior acionista diminuía a tendência dos retornos das ações se moverem em conjunto com o mercado. Vale lembrar que a sincronicidade e o risco idiossincrático são métricas complementares: se de um lado a sincronicidade é medida pelo $\mathrm{R}^{2}$, o retorno idiossincrático é pelo seu complemento: $1-\mathrm{R}^{2}$.

Analogamente, na abordagem da concentração acionária medida pela participação conjunta dos três maiores acionistas, a amostra também foi dividida em dois grupos com base no valor aproximado de Q3 (terceiro quartil). Neste caso, a participação de corte foi de $70 \%$. A Tabela 11 apresenta os testes univariados: teste $t$ de significância para diferença entre médias e o teste de postos sinalizados de Wilcoxon. Os resultados sugerem que existe diferença significativa no risco idiossincrático médio das empresas com alta concentração acionária em relação às demais. No grupo em que o maior acionista detém mais de $50 \%$ da participação total o risco idiossincrático é significativamente maior (valor-p $<0,01$ ) do que das empresas em que o principal acionista detém 50\% ou menos dos direitos de propriedade. Comportamento semelhante é observado quando a análise recai sobre a divisão da amostra com base na participação conjunta dos três maiores acionistas. A média do risco idiossincrático das empresas em que os três maiores acionistas detêm em 
conjunto mais de $70 \%$ do capital total é significativamente maior (valor-p $<0,01$ ) do que das demais.

Tabela 11: Testes estatísticos univariados para diferenças dos escores de risco idiossincrático

\begin{tabular}{|c|c|c|c|c|c|}
\hline & & $\mathrm{N}$ & Média & $\begin{array}{c}\text { Estatística t } \\
\text { (teste } \mathrm{t}, \text { bi-caudal) }\end{array}$ & $\begin{array}{l}\text { Estatística z para Teste } \\
\text { de postos Sinalizados de } \\
\text { Wilcoxon (bi-caudal) }\end{array}$ \\
\hline \multicolumn{6}{|c|}{ Concentração acionária do maior acionista } \\
\hline IDIO_1 & $\begin{array}{l}=\text { ou }<50 \% \\
>50 \%\end{array}$ & $\begin{array}{l}842 \\
298\end{array}$ & $\begin{array}{l}1,358 \\
1,742\end{array}$ & $-6,512^{* * *}$ & $-3,408^{* * *}$ \\
\hline IDIO_2 & $\begin{array}{l}=\text { ou }<50 \% \\
>50 \%\end{array}$ & $\begin{array}{l}791 \\
278\end{array}$ & $\begin{array}{l}1,174 \\
1,554\end{array}$ & $-6,196$ & $-3,638^{* \star \star}$ \\
\hline IDIO_3 & $\begin{array}{l}=\text { ou }<50 \% \\
>50 \%\end{array}$ & $\begin{array}{l}842 \\
298\end{array}$ & $\begin{array}{l}1,360 \\
1,743\end{array}$ & $-6,481^{\star \star \star}$ & $-3,401^{* * *}$ \\
\hline \multicolumn{6}{|c|}{ Concentração acionária dos três maiores acionistas } \\
\hline IDIO_1 & $\begin{array}{l}=\text { ou }<70 \% \\
>70 \%\end{array}$ & $\begin{array}{l}853 \\
287\end{array}$ & $\begin{array}{l}1,299 \\
1,932\end{array}$ & $-3,947^{* * *}$ & $-6,101^{* \star *}$ \\
\hline IDIO_2 & $\begin{array}{l}=\text { ou }<70 \% \\
>70 \%\end{array}$ & $\begin{array}{l}804 \\
265\end{array}$ & $\begin{array}{l}1,132 \\
1,699\end{array}$ & $-4,175^{* * *}$ & $-5,722^{* * *}$ \\
\hline IDIO_3 & $\begin{array}{l}=\text { ou }<70 \% \\
>70 \%\end{array}$ & $\begin{array}{l}853 \\
287 \\
\end{array}$ & $\begin{array}{l}1,301 \\
1,934\end{array}$ & $-3,926$ & $-6,093^{* * *}$ \\
\hline
\end{tabular}

A concentração acionária do maior acionista é "= ou < 50\%" quando a participação do maior acionista é menor ou igual a $50 \%$ do total das ações; " $>50 \%$ " quando a participação do maior acionista é maior do que $50 \%$ do total das ações. A concentração acionária dos três maiores acionistas é " $=$ ou $<70 \%$ " quando a participação acionária dos três maiores acionistas menor ou igual a $70 \%$ sobre o total das ações e $>70 \%$ maior do que $70 \%$ sobre o total das ações. $N$ corresponde ao número de observações em cada subamostra.

Além disso, ao organizar as empresas por quartis de participação acionária, tanto com base no maior acionista (Figura 3) quanto agrupando pela participação conjunta dos três maiores acionistas (Figura 4), a média do risco idiossincrático apresenta tendência de aumento à medida que aumenta a concentração da propriedade. Cabe salientar que quando os três maiores acionistas detêm mais de $70 \%$ das ações totais da empresa, o risco idiossincrático médio do grupo diferencia-se dos demais grupos de concentração acionária (Figura 4). Isso indica que, em média, as variações nos retornos da ação da empresa devido aos fatores específicos se mostraram notadamente maior nas empresas em que parcela importante dos direitos de propriedade estão concentradas em poucos acionistas. Se as variações de preços das ações decorrem das percepções dos acionistas em relação ao desempenho futuro e ao risco associado então a concentração acionária afeta 
o risco percebido, o desempenho ou então ao fluxo de informações sobre os fatores de risco e/ou desempenho.

\section{2,3}

2,1

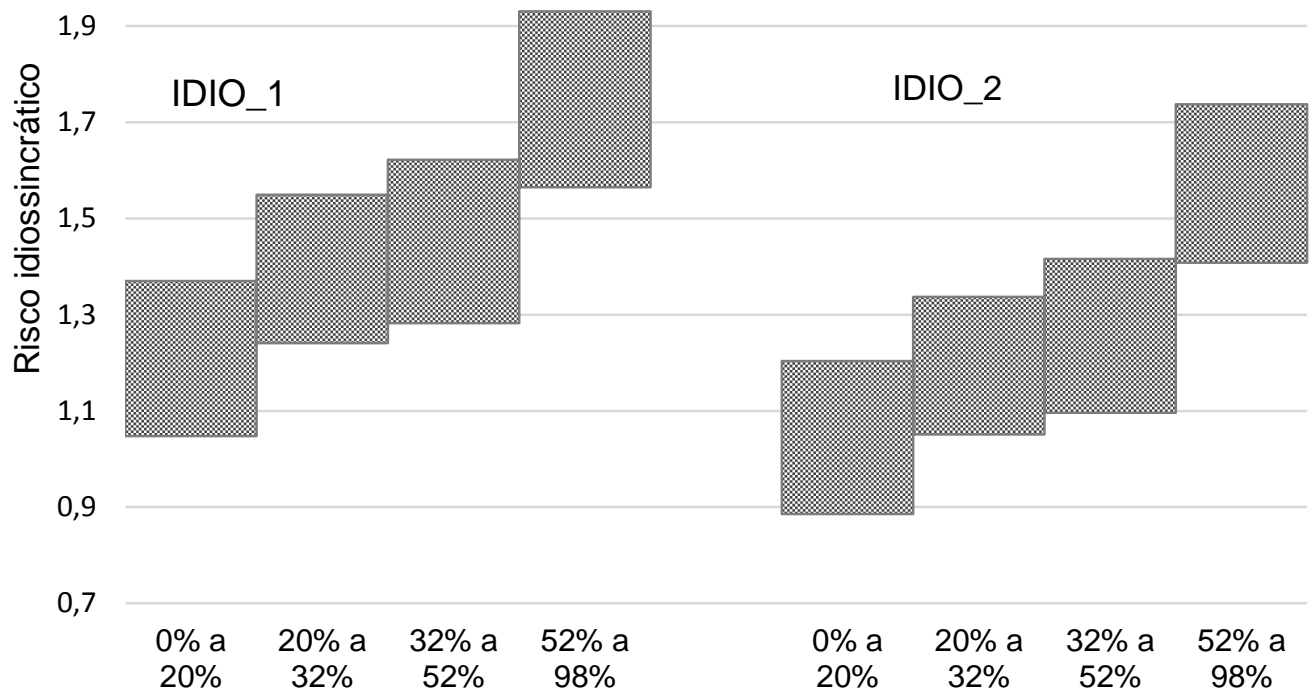

Quartis de participação acionária detida pelo maior acionista

Figura 3: Gráfico do intervalo de confiança Intervalo de Confiança para média IDIO_1 e IDIO2, agrupado pela participação do maior acionista.

Os agrupamentos por faixas de concentração de propriedade correspondem aos quartis da participação acionária do maior acionista. Os dados correspondem às observações da amostra no período 2002-2012. O intervalo de confiança foi construído com base em $95 \%$ de nível de confiança. 


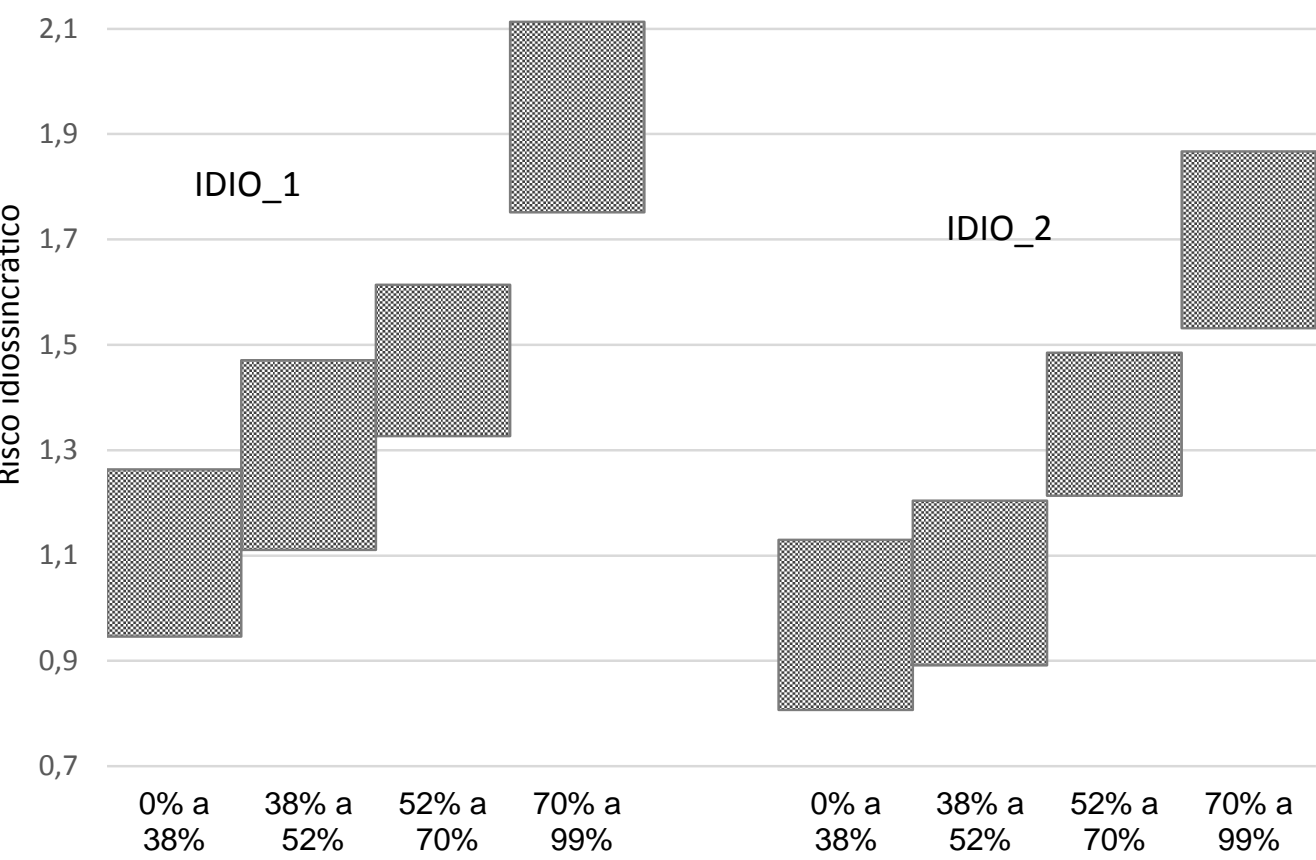

Quartis de participação acionária detida pelos três maiores acionistas

Figura 4 :Gráfico do intervalo de confiança para média IDIO_1 e IDIO2, agrupado pela participação dos três maiores acionistas

Os agrupamentos por faixas de concentração de propriedade, correspondem aos quartis da participação acionária dos três maiores acionistas. Os dados correspondem às observações da amostra no período 2002-2012. O intervalo de confiança foi construído com base em $95 \%$ de nível de confiança.

A relação linear entre o risco idiossincrático e a concentração acionária, na abordagem do maior acionista, foi avaliada utilizando o modelo multivariado descrito nas fórmulas 63 e 64. Os resultados da regressão estão apresentados na tabela Tabela 12. As colunas 63 e 64 da mesma tabela indicam que a regressão seguiu as equações 63 e 64, respectivamente. Os valores da estatística t reportados foram ajustados à heterocedasticidade (erros robustos) após identificar a presença pelo teste de Breusch-Pagan/Cook-Weisberg.

$$
\begin{aligned}
& I D I O \_1_{i, a}=\alpha+\beta_{1} C O N C_{-} P_{i, a}+\beta_{2} V M_{i, a}+\beta_{3} L I Q_{i, a}+\beta_{4} M t B_{i, a}+\beta_{5} E_{N D I V} \\
& +\beta_{6} R S P L_{i, a}+\beta_{7} \operatorname{TURN}_{i, a}+\beta_{8} D_{-} F I N_{i, a}+\varepsilon_{i, a} \\
& I D I O \_2_{i, a}=\alpha+\beta_{1} C O N C_{-} P_{i, a}+\beta_{2} V M_{i, a}+\beta_{3} L I Q_{i, a}+\beta_{4} M t B_{i, a}+\beta_{5} E N D I V_{i, a} \\
& +\beta_{6} R S P L_{i, a}+\beta_{7} \operatorname{TURN}_{i, a}+\beta_{8} D_{-} F I N_{i, a}+\varepsilon_{i, a}
\end{aligned}
$$


Tabela 12: Efeito da concentração de propriedade (maior acionista) sobre o risco idiossincrático.

Subamostra de empresas em que o maior Subamostra de empresas em que o maior acionista detém mais de $50 \%$ do total das acionista detém $50 \%$ ou menos do total das ações

\begin{tabular}{|c|c|c|c|c|c|c|c|c|c|c|c|c|c|c|}
\hline \multirow{3}{*}{$\begin{array}{l}\text { Equação } \\
\text { Variável } \\
\text { Intercepto }\end{array}$} & \multirow{3}{*}{ 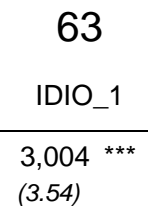 } & \multirow{3}{*}{$\begin{array}{l}64 \\
\text { IDIO_2 } \\
3,743^{* * *} \\
(4.12)\end{array}$} & \multirow{2}{*}{\multicolumn{2}{|c|}{$\begin{array}{c}63 \\
\text { IDIO_1 }\end{array}$}} & \multirow{2}{*}{\multicolumn{2}{|c|}{$\begin{array}{c}64 \\
\text { IDIO_2 }\end{array}$}} & \multirow{2}{*}{\multicolumn{2}{|c|}{$\begin{array}{c}63 \\
\text { IDIO_1 }\end{array}$}} & \multirow{2}{*}{\multicolumn{2}{|c|}{$\begin{array}{c}64 \\
\text { IDIO_2 }\end{array}$}} & \multirow{2}{*}{\multicolumn{2}{|c|}{$\begin{array}{c}63 \\
\text { IDIO_1 }\end{array}$}} & \multirow{2}{*}{\multicolumn{2}{|c|}{$\begin{array}{c}64 \\
\text { IDIO_2 }\end{array}$}} \\
\hline & & & & & & & & & & & & & & \\
\hline & & & $\begin{array}{r}3,695 \\
(4.11)\end{array}$ & $* \star \star$ & $\begin{array}{r}4,302 \\
(5.36)\end{array}$ & $\star \star \star *$ & $\begin{array}{r}6,177 \\
(13.78)\end{array}$ & $\star \star \star *$ & $\begin{array}{r}6,179 \\
(14.49)\end{array}$ & $* * *$ & $\begin{array}{r}5,913 \\
(15.51)\end{array}$ & $\star \star \star \star$ & $\begin{array}{r}5,899 \\
(15.28)\end{array}$ & $* * *$ \\
\hline CONC_P & $\begin{array}{c}0,308 \text { * } \\
(1.83)\end{array}$ & $\begin{array}{r}0,246 \\
(1.33)\end{array}$ & $\begin{array}{r}0,298 \\
(2.29)\end{array}$ & ** & $\begin{array}{r}0,206 \\
(1.68)\end{array}$ & * & $\begin{array}{r}0,121 \\
(2.56)\end{array}$ & *** & $\begin{array}{r}0,111 \\
(2.58)\end{array}$ & $* * *$ & $\begin{array}{r}0,112 \\
(3.26)\end{array}$ & $\star \star *$ & $\begin{array}{r}0,106 \\
\text { (3.3) }\end{array}$ & $* \star *$ \\
\hline VM & $\begin{array}{c}-0,110 * \\
(-1,88)\end{array}$ & $\begin{array}{l}-0,153 * * \\
(-2,55)\end{array}$ & $\begin{array}{l}-0,157 \\
(-2,49)\end{array}$ & ** & $\begin{array}{r}-0,190 \\
(-3,51)\end{array}$ & $* * *$ & $\begin{array}{l}-0,322 \\
(-10,69)\end{array}$ & *** & $\begin{array}{l}-0,330 \\
(-11,56)\end{array}$ & $* * *$ & $\begin{array}{l}-0,304 \\
(-11,77)\end{array}$ & $* * *$ & $\begin{array}{r}-0,311 \\
(3,24)\end{array}$ & $* \star *$ \\
\hline LIQ & $\begin{array}{l}-0,503^{* * *} \\
(-4,49)\end{array}$ & $\begin{array}{l}-0,390 \text { *** } \\
(-3,75)\end{array}$ & $\begin{array}{r}-0,453 \\
(-4,68)\end{array}$ & $\star \star * *$ & $\begin{array}{r}-0,379 \\
(-4,39)\end{array}$ & $* \star *$ & $\begin{array}{r}-0,124 \\
(-5,52)\end{array}$ & *** & $\begin{array}{r}-0,110 \\
(-5,38)\end{array}$ & $* * *$ & $\begin{array}{r}-0,140 \\
(-6,32)\end{array}$ & $* * *$ & $\begin{array}{r}-0,127 \\
(-6,03)\end{array}$ & $* * *$ \\
\hline MtB & $\begin{array}{r}0,230 \\
(0,62)\end{array}$ & $\begin{array}{r}-0,017 \\
(-0,45)\end{array}$ & $\begin{array}{r}0,051 \\
(2,15)\end{array}$ & & $\begin{array}{r}0,030 \\
(1,06)\end{array}$ & & $\begin{array}{r}0,483 \\
(3,99)\end{array}$ & *** & $\begin{array}{r}0,042 \\
(3,73)\end{array}$ & $* * *$ & $\begin{array}{r}0,030 \\
(2,83)\end{array}$ & $* * *$ & $\begin{array}{r}0,026 \\
(2,61)\end{array}$ & $* * *$ \\
\hline ENDIV & $\begin{array}{r}-0,078 \\
(-1,57)\end{array}$ & $\begin{array}{r}-0,036 \\
(-0,76)\end{array}$ & & & & & $\begin{array}{r}-0,030 \\
(-2,31)\end{array}$ & ** & $\begin{array}{r}-0,370 \\
(-2,94)\end{array}$ & $\star \star \star *$ & & & & \\
\hline RSPL & $\begin{array}{l}0,672 \text { ** } \\
(2,12)\end{array}$ & $\begin{array}{l}0,758 \text { *** } \\
(2,88)\end{array}$ & & & & & $\begin{array}{r}-0,005 \\
(-2,75)\end{array}$ & $* * *$ & $\begin{array}{r}0,002 \\
(1,22)\end{array}$ & & & & & \\
\hline TURN & $\begin{array}{l}-0,068^{\text {***}} \\
(-2,79)\end{array}$ & $\begin{array}{r}-0,109 \\
(-0,41)\end{array}$ & $\begin{array}{r}-0,075 \\
(-3,75)\end{array}$ & $\star \star *$ & $\begin{array}{r}-0,024 \\
(-1,06)\end{array}$ & & $\begin{array}{r}-0,027 \\
(-2,02)\end{array}$ & ** & $\begin{array}{r}-0,012 \\
(-1,04)\end{array}$ & & $\begin{array}{r}-0,021 \\
(-1,69)\end{array}$ & * & $\begin{array}{l}-0,011 \\
(-0,94)\end{array}$ & \\
\hline D_FIN & & & $\begin{array}{r}-0,669 \\
(-3,27)\end{array}$ & $* * *$ & $\begin{array}{r}-0,650 \\
(-3,75)\end{array}$ & $\star * \star$ & & & & & $\begin{array}{r}-0,197 \\
(0,14)\end{array}$ & & $\begin{array}{r}-0,206 \\
(-1,62)\end{array}$ & \\
\hline $\mathrm{N}$ & 234 & 224 & 293 & & 274 & & 722 & & 684 & & 813 & & 770 & \\
\hline $\mathrm{R}^{2}$ & 0,206 & 0,171 & 0,229 & & 0,230 & & 0,320 & & 0,348 & & 0,355 & & 0,381 & \\
\hline
\end{tabular}

Os números entre parêntesis correspondem à estatística $t$ ajustada para correção de heterocedasticidade. D_FIN é a variável dummy que assume valor 1 para empresas do setor financeiro e 0 para as demais empresas. Foram excluídas as observações que geraram resíduos discrepantes. Os sinais: * ${ }^{* *} \mathrm{e}^{* * *}$ correspondem os níveis de significância $10 \% ; 5 \%$ e $1 \%$ respectivamente. As variáveis utilizadas estão descritas na Tabela 3. Os resultados das regressões utilizando a métrica IDIO_3 foram omitidos tendo em vista que os resultados foram quase idênticos àqueles obtidos com a medida IDIO_1.

Como o estudo não restringiu as empresas financeiras das não financeiras, quando as variáveis de controle referiam-se exclusivamente às empresas não financeiras (endividamento: ENDIV; retorno sobre o patrimônio líquido: RSPL) naturalmente os resultados não incluíram as empresas daquele setor. Ao omitir ENDIV e RSPL do modelo, as empresas do setor financeiro são incluídas e o efeito específico da empresa atuar no setor financeiro é capturado pela variável categórica (dummy) que assume valor 0 (zero) quando a empresa não é do setor financeiro a valor 1 (um) quando a empresa é do setor financeiro. 
Os resultados reportados na Tabela 12 indicam que, na subamostra das empresas com o maior acionista detendo mais de $50 \%$ dos direitos de propriedade, na presença das demais variáveis, a variação na concentração de propriedade não se mostrou consistentemente relevante na explicação do risco idiossincrático, ao nível de significância de 5\%. Ainda que se tenha constatado que as empresas em que o maior acionista detém mais de $50 \%$ das ações tem em média risco idiossincrático maior do que as demais empresas (valor$\mathrm{p}<0,01)$, nesse grupo, o aumento na concentração não afetou o risco idiossincrático. Nota-se a presença de algumas empresas do setor financeiro em que o principal acionista detém mais de $50 \%$ do total das ações e têm risco idiossincrático menor, ceteris paribus. Entre as empresas financeiras que se enquadraram nesse grupo ${ }^{42}$ estão, por exemplo: Santander em 2008, Unibanco entre 2002 e 2007, ABC Brasil em 2011, Sofisa entre 2009 a 2011.

Em relação ao efeito conjunto das variáveis sobre o risco idiossincrático, a liquidez em bolsa (LIQ) e o retorno sobre o patrimônio líquido (RSPL), variáveis que a teoria aponta como importantes no delineamento do risco idiossincrático como, influenciam o risco idiossincrático. Os coeficientes das variáveis que representam as oportunidades de crescimento (MtB) e o endividamento (ENDIV) e o Turnover não foram significantes.

Já na subamostra das empresas em que o maior acionista detém $50 \%$ ou menos dos direitos de propriedade, a concentração acionária está positivamente relacionada ao risco idiossincrático (valor- $p<0,01$ ), enquanto em tal grupo, a não significância do coeficiente da variável dummy : D_FIN indica as empresas do setor financeiro não se distinguiram das demais em relação ao risco idiossincrático.

As evidências da análise multivariada apontam para a interpretação de que o risco idiossincrático sofre influência da concentração de propriedade na medida em que interfere no tipo de informação que será incorporada aos preços. Isso porque os coeficientes das variáveis que representam as oportunidades de

42 A título de esclarecimento, nem todas as empresas que fizeram parte da amostra foram analisadas nos 11 anos do estudo. Algumas empresas não foram incluídas em alguns anos, seja por razão do critério de liquidez em bolsa, seja por que a regressão dos retornos em relação aos fatores sistemáticos por não apresentou normalidade dos resíduos. 
crescimento (MtB) e o endividamento (ENDIV) foram positivamente significantes (valor- $p<0,05$ ) para o grupo de empresas em que o acionista majoritário detém menos do que a maioria absoluta do total das ações. Porém não se mostrou relevante no outro grupo. Tal observação pode indicar que divergências no impacto das oportunidades de crescimento e das decisões sobre a estrutura de capital (ENDIV) estão mais intensamente refletidas nos preços das ações das empresas em que nenhum acionista detém isoladamente a maioria das ações da empresa.

Os resultados são confirmados quando a análise multivariada do efeito da concentração acionária sobre o risco idiossincrático foi com base na participação conjunta dos três maiores acionistas. Na Tabela 13 são apresentados os resultados da regressão correspondentes às fórmulas 65 e 66 onde as variáveis dependentes correspondem às métricas do risco idiossincrático IDIO_1 e IDIO_2. O grupo de acionista (blockholder) foi considerado como sendo "grande" quando a participação dos três maiores acionistas corresponde, em conjunto, pelo menos a $70 \%$ do total das ações. Essa subamostra corresponde, aproximadamente, ao conjunto das empresas que estão no último quartil de participação acionária dos três maiores acionistas.

$$
\begin{aligned}
& I D I O \_1_{i, a}=\alpha+\beta_{1} C O N C \_3_{i, a}+\beta_{2} V M_{i, a}+\beta_{3} L I Q_{i, a}+\beta_{4} M t B_{i, a}+\beta_{5} \operatorname{ENDIV}_{i, a} \\
& +\beta_{6} R S P L_{i, a}+\beta_{7} \operatorname{TURN}_{i, a}+\beta_{8} D_{-} F I N_{i, a}+\varepsilon_{i, a} \\
& I D I O \_2_{i, a}=\alpha+\beta_{1} C O N C \_3_{i, a}+\beta_{2} V M_{i, a}+\beta_{3} L I Q_{i, a}+\beta_{4} M t B_{i, a}+\beta_{5} E_{N D I V} V_{i, a} \\
& +\beta_{6} R S P L_{i, a}+\beta_{7} \operatorname{TURN}_{i, a}+\beta_{8} D_{-} F I N_{i, a}+\varepsilon_{i, a}
\end{aligned}
$$


Tabela 13: Efeito da concentração de propriedade (três maiores acionistas) sobre o risco idiossincrático.

Subamostra de empresas em que os três Subamostra de empresas em que os três maiores acionistas detêm em conjunto maiores acionistas detêm em conjunto $70 \%$ ou mais de $70 \%$ do total das ações

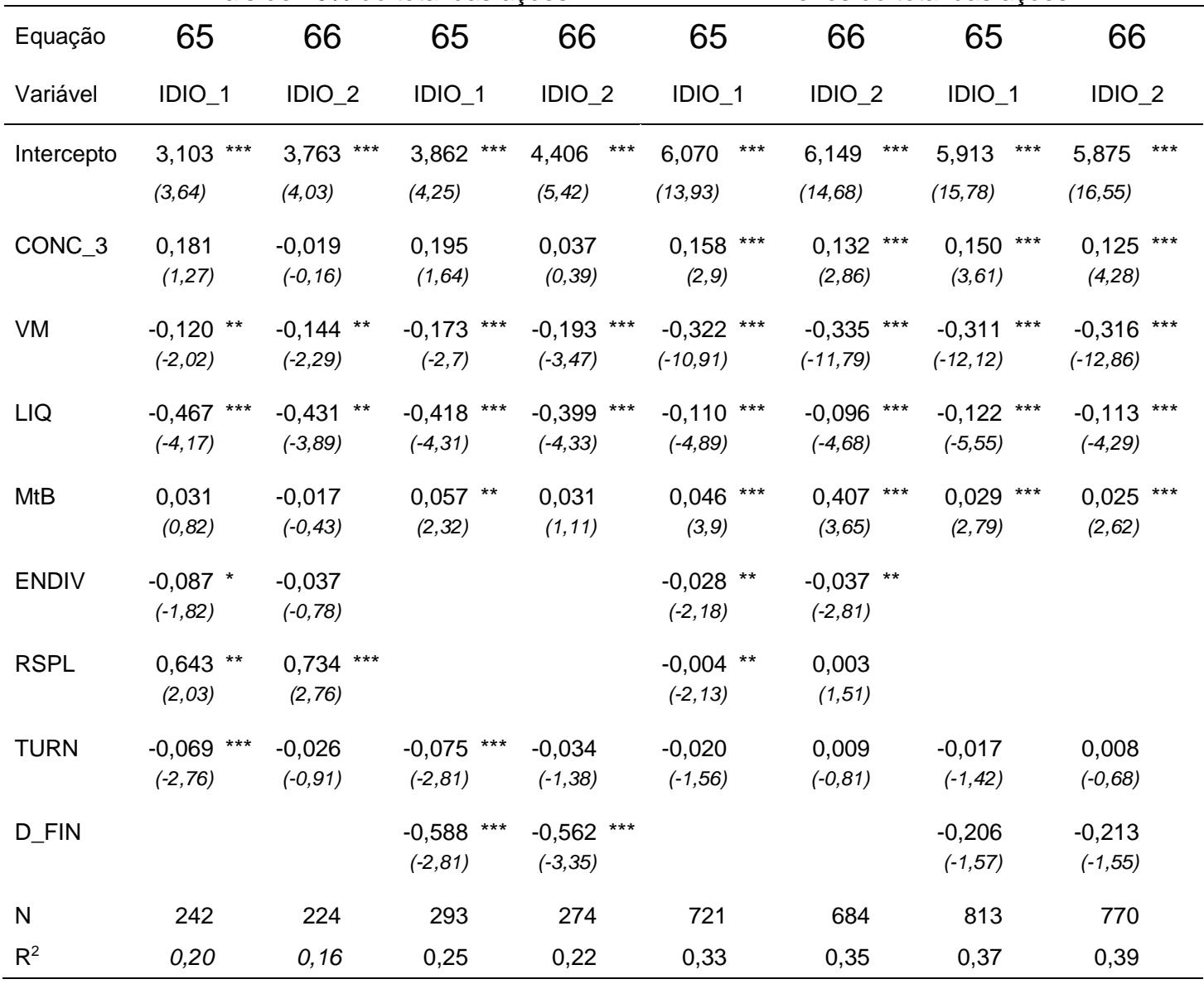

Os números entre parêntesis correspondem à estatística $\mathrm{t}$ ajustada para correção de heterocedasticidade. D_FIN é a variável dummy que assume valor 1 para empresas do setor financeiro e 0 para as demais empresas. Foram excluídas as observações que geraram resíduos discrepantes. Os sinais: ${ }^{*},{ }^{* *} e^{* * *}$ correspondem os níveis de significância $10 \% ; 5 \%$ e $1 \%$ respectivamente. As variáveis utilizadas estão descritas na Tabela 3. Os resultados das regressões utilizando a métrica IDIO_3 foram omitidos tendo em vista que os resultados foram quase idênticos àqueles obtidos com a medida IDIO_1.

Pelos resultados apresentados na Tabela 14 verifica-se que nem todas as empresas que compuseram a subamostra de grande concentração acionária pelo critério do maior acionista fazem parte da subamostra das empresas com alta concentração acionária pelo critério da participação dos três maiores acionistas. Do total das 1.114 empresas analisadas, 78 compuseram o grupo em que os três maiores acionistas detêm mais de $70 \%$ do total das ações e o maior acionista possui $50 \%$ ou menos do total das ações. Por outro lado, do total das empresas analisadas 107 compuseram o grupo das que os três 
maiores acionistas detêm $70 \%$ ou menos do total das ações e o maior acionista possui mais de $50 \%$ do total das ações.

Tabela 14: Estatística descritiva da participação acionária

\begin{tabular}{lrrrrr}
\hline $\begin{array}{c}\text { Subamostras por participação acionária do } \\
\text { maior e dos três maiores acionistas, } \\
\text { simultaneamente }\end{array}$ & N & Média & $\begin{array}{c}\text { Participação do } \\
\text { maior acionista } \\
\text { pesvio } \\
\text { padrão }\end{array}$ & $\begin{array}{c}\text { Participação dos } \\
\text { três maiores } \\
\text { acionistas } \\
\text { Desvio } \\
\text { padrão }\end{array}$ \\
\hline Maior acionista $<=50 \%$ e três maiores $<=70 \%$ & 764 & 25,71 & 12,01 & 42,42 & 15,38 \\
Maior acionista $<=50 \%$ e três maiores $>70 \%$ & 78 & 39,23 & 7,28 & 77,32 & 6,11 \\
Maior acionista $>50 \%$; três maiores $<=70 \%$ & 107 & 57,66 & 5,06 & 63,65 & 4,98 \\
Maior acionista $>50 \%$; três maiores $>70 \%$ & 192 & 69,06 & 12,20 & 82,21 & 8,20 \\
\hline
\end{tabular}

Estatística descritiva das participações acionárias do maior acionista e dos três maiores acionistas, organizadas por subamostras de participação acionária em que: Maior acionista > (<=) $50 \%$ corresponde às empresas em que o maior acionista detém mais (exatamente ou menos de) de $50 \%$ do total das ações; três maiores > (<=) 70\% corresponde às empresas em que os três maiores acionistas detém mais (exatamente ou menos de) $70 \%$ do total das ações.

Em tendo sido observado, inclusive na literatura, que o risco idiossincrático é afetado pelo tamanho da empresa e sendo a concentração de propriedade um fator que também está relacionado ao risco idiossincrático, cabe analisar o tamanho médio das empresas por faixas de concentração de propriedade. Dessa forma, para cada quartil de concentração acionária tanto do maior acionista quanto dos três maiores acionistas, foram tomadas as médias dos valores das empresas, atualizadas monetariamente a valores de 2012.

Os resultados representados na Figura 5, cujos valores estão detalhados na Tabela 15, sugerem que as empresas nas quais o maior acionista detém até $20 \%$ das ações tendem a ser, em média de menor valor de mercado. Também apresentam menor dispersão dos valores em torno da média e menor coeficiente de variação, ainda que com base em $95 \%$ de confiança não se possa rejeitar a hipótese de que as empresas tenham, em média, risco idiossincrático significativamente igual quando comparado com as médias dos outros grupos. Ainda assim, verifica-se que na amostra analisada, o maior valor de empresa entre aquelas em que o principal acionista tem menos de $20 \%$ das ações correspondeu a $\mathrm{R} \$ 59$ bilhões enquanto nos demais grupos a maior empresa não valia menos de $R \$ 100$ bilhões. Porém, quando se observa o valor de mercado médio, organizado pelos quartis da participação acionária dos três 
maiores acionistas, não se percebe uma predominância em favor de algum dos grupos (Tabela 15).

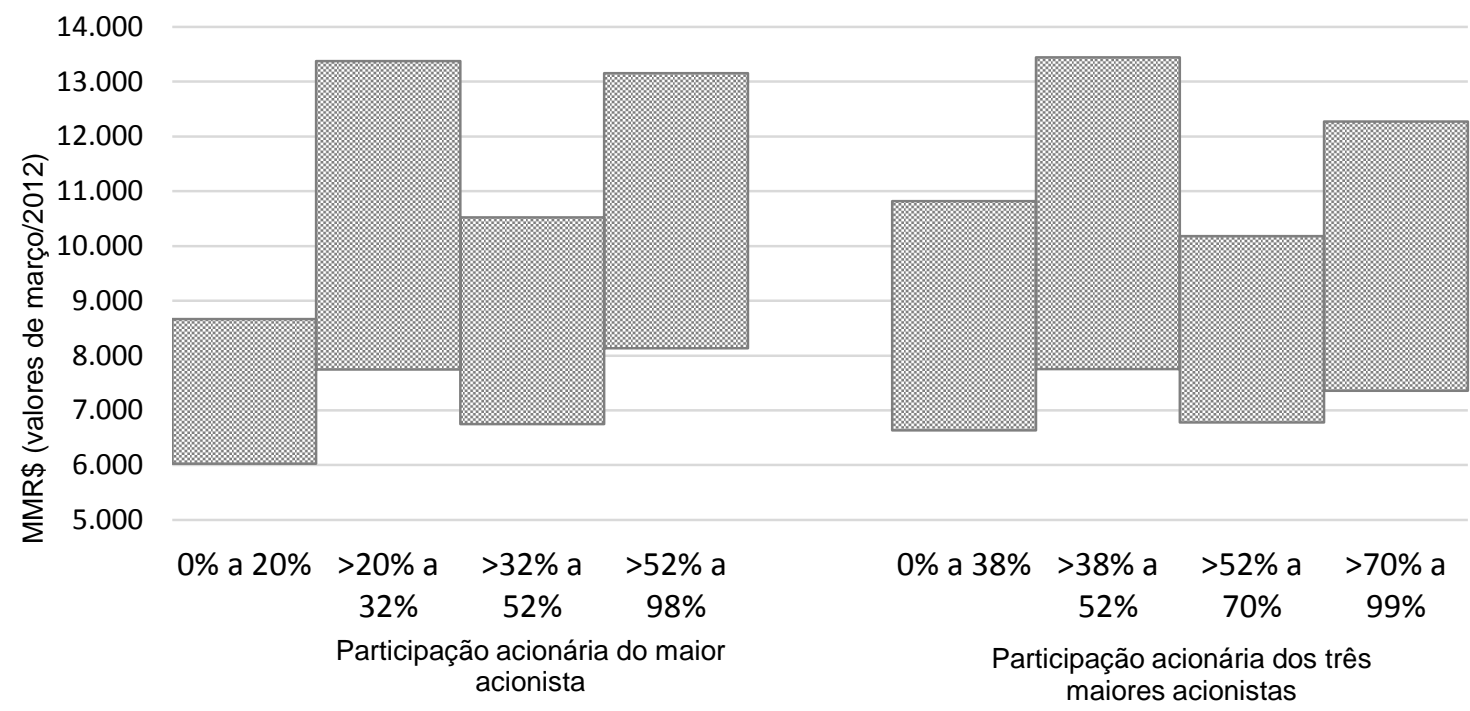

Figura 5: gráfico do intervalo de confiança do valor de mercado médio das empresas por grupos de participação acionária

Os agrupamentos por faixas de concentração de propriedade correspondem aos quartis da participação acionária do maior acionista e dos três maiores acionistas. Os dados correspondem às observações da amostra no período 2002-2012. Foram excluídas nesse gráfico as observações correspondentes às empresas Petrobrás e Vale. O intervalo de confiança foi construído com $95 \%$ de nível de confiança.

Tabela 15: Estatística descritiva do valor de mercado das empresas por quartil de participação acionária

\begin{tabular}{|c|c|c|c|c|c|c|c|c|c|}
\hline $\begin{array}{l}\text { Participação } \\
\text { do maior } \\
\text { acionista }\end{array}$ & Observações & $\begin{array}{l}\text { Valor } \\
\text { médio }\end{array}$ & $\begin{array}{l}\text { Desvio } \\
\text { Padrão }\end{array}$ & $\begin{array}{l}\text { Coeficiente } \\
\text { de variação }\end{array}$ & Mínimo & Máximo & Mediana & \multicolumn{2}{|c|}{$\begin{array}{c}\text { Intervalo de } \\
\text { Confiança } \\
(95 \%)\end{array}$} \\
\hline $0 \%$ a $20 \%$ & 250 & 7,348 & 10,590 & 1,441 & 14 & 59,231 & 670 & 6,029 & 8,668 \\
\hline$>20 \%$ a $32 \%$ & 299 & 10,563 & 24,736 & 2,342 & 10 & 175,098 & 1,431 & 7,747 & 13,378 \\
\hline$>32 \%$ a $52 \%$ & 283 & 8,636 & 16,126 & 1,867 & 5 & 103,707 & 959 & 6,749 & 10,523 \\
\hline$>52 \%$ a $98 \%$ & 288 & 0,643 & 21,642 & 2,033 & 31 & 213,511 & 1,275 & 8,133 & 13,154 \\
\hline $\begin{array}{c}\text { Participação } \\
\text { dos três } \\
\text { maiores } \\
\text { acionistas }\end{array}$ & Observações & $\begin{array}{l}\text { Valor } \\
\text { médio }\end{array}$ & $\begin{array}{l}\text { Desvio } \\
\text { Padrão }\end{array}$ & $\begin{array}{l}\text { Coeficiente } \\
\text { de variação }\end{array}$ & Mínimo & Máximo & Mediana & \multicolumn{2}{|c|}{$\begin{array}{c}\text { Intervalo de } \\
\text { Confiança } \\
(95 \%)\end{array}$} \\
\hline $0 \%$ a $38 \%$ & 257 & 8,729 & 17,022 & 1,950 & 5 & 116,335 & 1,062 & 6,638 & 10,820 \\
\hline$>38 \%$ a $52 \%$ & 263 & 10,599 & 23,413 & 2,209 & 10 & 175,098 & 1,444 & 7,756 & 13,442 \\
\hline$>52 \%$ a $70 \%$ & 312 & 8,482 & 15,269 & 1,800 & 18 & 103,707 & 864 & 6,781 & 10,183 \\
\hline$>70 \%$ a $99 \%$ & 288 & 9,817 & 21,198 & 2,159 & 31 & 213,511 & 1,249 & 7,358 & 12,276 \\
\hline
\end{tabular}

A tabela apresenta os valores das estatísticas descritivas do valor médio de mercado das empresas nos quatis de participação acionária do maior e dos três maiores acionistas. O Valor médio foi obtido a partir do valor de mercado das empresas que compuseram esse estudo, em milhões de reais atualizados a valores de março de 2012, com base na variação do IPCA, organizadas por quartis das participações acionárias do maior acionista e dos três maiores acionistas. Para o cálculo dos valores dessa tabela foram excluídas as observações referentes às empresas Petrobrás e Vale, tendo em vista que o valor de mercado dessas empresas poderia distorcer os resultados, por serem empresas com valor muito acima das empresas mais valorizadas no mercado brasileiro. 
Portanto, foi confirmada a Hipótese 1 deste trabalho: O risco idiossincrático aumenta a medida em que aumenta percentual da participação do maior acionista, ceteris paribus.

\subsection{Liquidez, concentração acionária e risco idiossincrático}

A concentração acionária afeta a liquidez em bolsa das ações das empresas, na medida em que quanto maior a concentração acionária, menor a parcela das ações disponíveis aos investidores. No entanto é possível que grandes empresas com alta concentração possam ter suas ações mais líquidas do que empresas de menor porte com ações altamente pulverizadas. A correlação entre a liquidez em bolsa e a participação do maior acionista (dos três maiores acionistas) foi de $13 \%$ (24\%) (Tabela 5).

A análise da liquidez em bolsa por subamostras de participação acionária ${ }^{43}$ (Figura 6), indica que o grupo de empresas com alta concentração acionária tem valor médio de liquidez em bolsa significativamente menor do que as empresas com menor concentração, ceteris paribus. Entretanto, não se verificou diferença significativa na liquidez média das ações das empresas nos grupos em que a concentração dos direitos de propriedade representa $52 \%$ ou menos do total das ações detidas pelo maior acionista ou em conjunto pelos três maiores acionistas.

Por outro lado, observou-se pela Tabela 5 que a liquidez em bolsa está negativamente correlacionada (valor- $p<0,01$ ) ao risco idiossincrático e a concentração acionária está positivamente correlacionada (valor- $p<0,01$ ). Então, menor liquidez resultante da menor disponibilidade de ações no mercado afeta positivamente o risco idiossincrático e parte do risco idiossincrático observado nas ações das empresas com alta participação acionária deve ser decorrente do efeito da concentração acionária sobre a liquidez em bolsa.

\footnotetext{
${ }^{43}$ As subamostras foram organizadas por quartis de participação acionária
} 


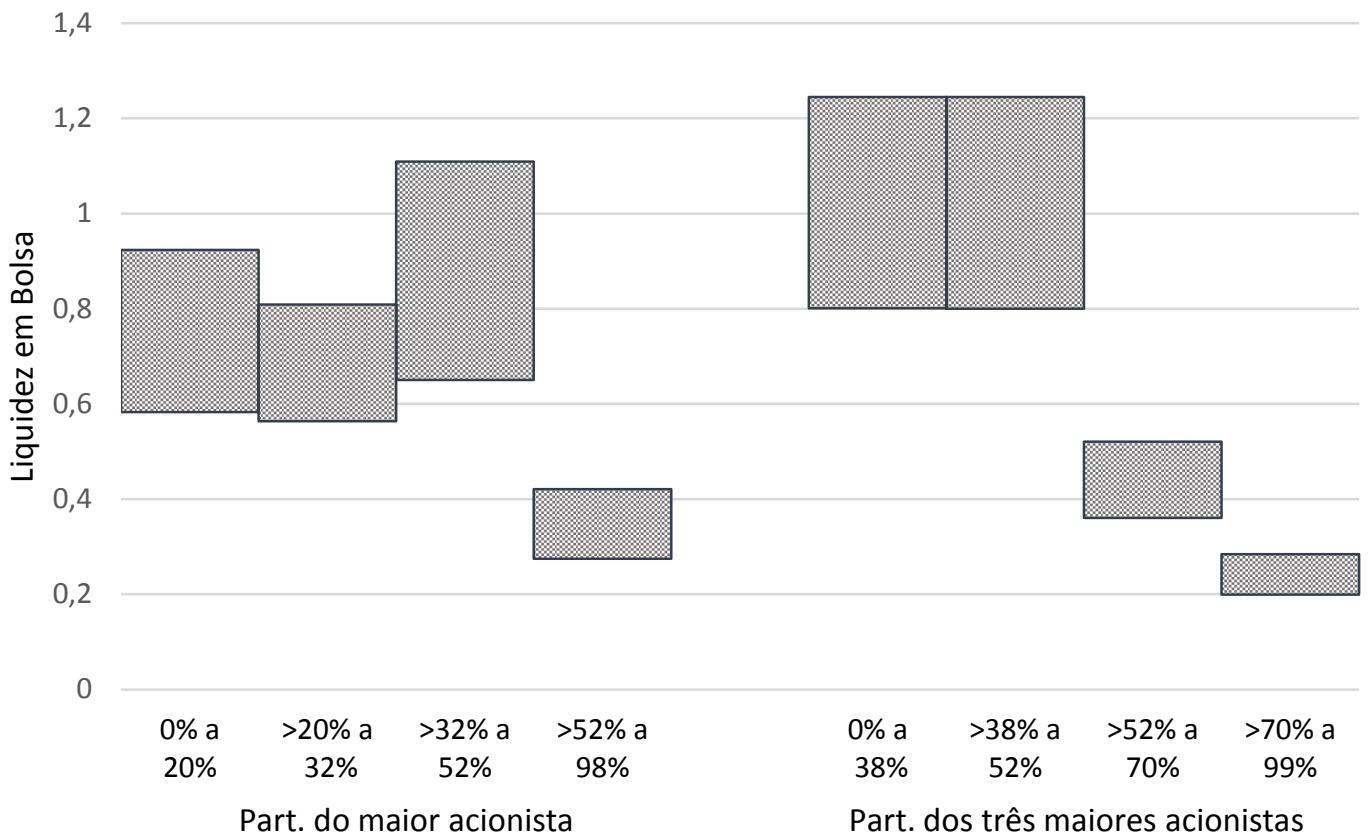

Figura 6: Gráfico do intervalo de confiança da média da liquidez em bolsa, para nível de confiança de $95 \%$,

Os agrupamentos por faixas de concentração de propriedade, correspondem aos quartis da participação acionária do maior acionista e dos três maiores acionistas. Os dados correspondem às observações da amostra no período 2002-2012. O intervalo de confiança foi construído com base em $95 \%$ de nível de confiança.

Tabela 16: Critério para o agrupamento das subamostras organizadas por liquidez em bolsa e participação dos três maiores acionistas

\begin{tabular}{llll}
\hline Abreviação & Descrição & Variável & Critério \\
\hline B.Liq. & Baixa Liquidez & Liquidez em bolsa & Abaixo da mediana \\
A.Liq. & Alta Liquidez & & Acima da mediana \\
B.Con. & Baixa concentração & Participação acionária dos três & Abaixo do 3o quartil \\
A.Con. & Alta concentração & maiores acionistas & Acima do 3o quartil \\
\hline
\end{tabular}

A tabela descreve os critérios para a composição das subamostras organizadas por nível de liquidez em bolsa e concentração acionária considerados conjuntamente. O critério "abaixo (acima) da mediana" indica que foram consideradas as observações em que a variável correspondente apresentava valores abaixo(acima) da mediana, Analogamente para o critério "abaixo (acima) do $3^{\circ}$ quartil.

Para aprofundar o entendimento sobre o efeito conjunto da liquidez e concentração acionária sobre o risco idiossincrático, a amostra foi separada em subamostras de observações em que estavam presentes, simultaneamente os aspectos de liquidez em bolsa e concentração acionária, conforme detalhado na Tabela 16. 
Quando é analisado o comportamento das ações do conjunto das empresas em que a liquidez está acima da mediana (Figura 7), verifica-se que o risco idiossincrático é significativamente maior (valor- $p<0,01)$ para as observações das empresas com alta concentração acionária. Tal constatação indica que parte do risco idiossincrático é atribuído à liquidez em bolsa, mas parcela do risco idiossincrático deve estar associada à concentração acionária. Isso por que embora o risco idiossincrático seja menor na subamostra das ações com alta concentração acionária, quando a liquidez em bolsa é alta, o risco idiossincrático médio das empresas com baixa concentração acionária é significativamente menor do que o risco idiossincrático médio das empresas com alta concentração acionária.

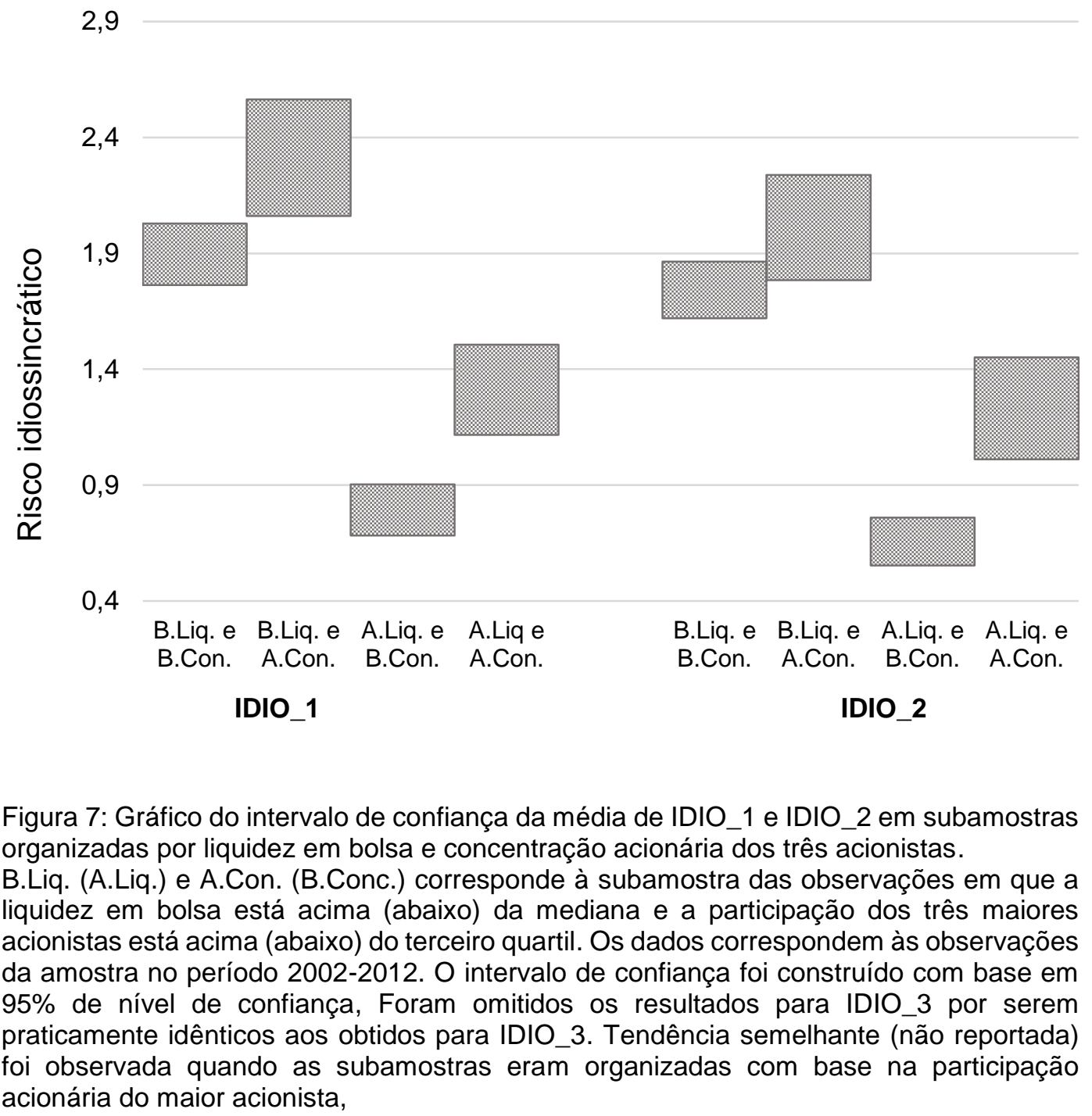


Tabela 17: Testes estatísticos univariados para diferenças dos escores de risco idiossincrático

\begin{tabular}{|c|c|c|c|c|c|}
\hline $\begin{array}{c}\text { Medida de } \\
\text { Risco } \\
\text { idiossincrático }\end{array}$ & Critério & $\mathrm{N}$ & Média & $\begin{array}{c}\text { Estatística t } \\
\text { (teste t, bi-caudal) }\end{array}$ & $\begin{array}{l}\text { Estatística z para } \\
\text { Teste de postos } \\
\text { Sinalizados de } \\
\text { Wilcoxon (bi-caudal) }\end{array}$ \\
\hline \multicolumn{6}{|c|}{ Concentração acionária medida com base na participação do maior acionista } \\
\hline \multicolumn{6}{|c|}{ Baixa liquidez em bolsa } \\
\hline \multirow[t]{2}{*}{ IDIO_1 } & baixa concentração & 397 & 1,971 & $-1,362$ & $-0,395$ \\
\hline & alta concentração & 172 & 1,742 & & \\
\hline \multicolumn{6}{|c|}{ Alta liquidez em bolsa } \\
\hline \multirow[t]{2}{*}{ IDIO_1 } & baixa concentração & 456 & 0,829 & $-2,515 * *$ & $-2,792 * * *$ \\
\hline & alta concentração & 115 & 1,742 & & \\
\hline \multicolumn{6}{|c|}{ Baixa liquidez em bolsa } \\
\hline \multirow[t]{2}{*}{ IDIO_2 } & baixa concentração & 354 & 1,781 & $-1,193$ & $-0,622$ \\
\hline & alta concentração & 157 & 1,742 & & \\
\hline \multicolumn{6}{|c|}{ Alta liquidez em bolsa } \\
\hline \multirow[t]{2}{*}{ IDIO_2 } & baixa concentração & 446 & 0,688 & $-3,259 * * *$ & $-3,056 * * *$ \\
\hline & alta concentração & 112 & 1,742 & & \\
\hline
\end{tabular}

Concentração acionária medida com base na participação dos três maiores acionistas Baixa liquidez em bolsa

\begin{tabular}{|c|c|c|c|c|c|c|c|}
\hline \multirow[t]{2}{*}{ IDIO_1 } & baixa concentração & 391 & 1,896 & \multirow[t]{2}{*}{$-3,157$} & \multirow[t]{2}{*}{ *** } & \multirow[t]{2}{*}{$-2,607$} & \multirow[t]{2}{*}{ *** } \\
\hline & alta concentração & 178 & 1,742 & & & & \\
\hline \multicolumn{8}{|c|}{ Alta liquidez em bolsa } \\
\hline \multirow[t]{2}{*}{ IDIO_1 } & baixa concentração & 462 & 0,793 & $-4,154$ & $* * *$ & $-4,613$ & *** \\
\hline & alta concentração & 109 & 1,742 & & & & \\
\hline \multicolumn{8}{|c|}{ Baixa liquidez em bolsa } \\
\hline \multirow[t]{2}{*}{ IDIO_2 } & baixa concentração & 352 & 1,742 & $-2,234$ & ** & $-1,606$ & \\
\hline & alta concentração & 159 & 1,742 & & & & \\
\hline \multicolumn{8}{|c|}{ Alta liquidez em bolsa } \\
\hline \multirow[t]{2}{*}{ IDIO_2 } & baixa concentração & 452 & 0,657 & $-4,742$ & $\star * *$ & $-4,855$ & *** \\
\hline & alta concentração & 106 & 1,742 & & & & \\
\hline
\end{tabular}

Testes univariados para avaliar as diferenças entre os escores de risco idiossincrático para as subamostras organizadas por liquidez em bolsa e concentração acionária, conjuntamente. As subamostras analisadas nesta tabela seguem as definições da Tabela 16. Baixa (alta) liquidez em bolsa corresponde às observações em que a liquidez em bolsa estavam abaixo (acima) da mediana, Alta (baixa) concentração refere-se à concentração acionária acima (abaixo) do terceiro quartil, Foram omitidos os resultados para o risco idiossincrático medida pela variável IDIO_3 pois os resultados foram praticamente idênticos àqueles verificados para IDIO_1. Os sinais: * ${ }^{* *} \mathrm{e}^{* * *}$ correspondem os níveis de significância 10\%; $5 \%$ e $1 \%$ respectivamente.

Foram implementados dois testes: teste de significância para médias e teste de postos sinalizados de Wilcoxon para avaliar a diferença entre os valores médios do risco idiossincrático para os grupos de empresas com alta e com baixa concentração de propriedade. Como o risco idiossincrático é influenciado pela liquidez em bolsa, os dados foram divididos em subamostras conforme especificado na Tabela 16. Os resultados apresentados na Tabela 17 confirmam que na subamostra das empresas em que as ações são ativamente negociadas (alta liquidez) o risco idiossincrático médio das ações das empresas 
com baixa concentração de propriedade é significativamente menor (valor$p<0,01)$ do que das empresas com alta concentração, tanto quando se analisa a concentração pela participação do maior acionista quanto pela participação conjunta dos três maiores acionistas.

\subsection{Impacto da opacidade sobre o risco idiossincrático: modelo e resultados}

A falta de clareza na comunicação entre empresa e mercado (opacidade) foi avaliada por três métricas, obtidas a partir de duas metodologias. As variáveis estão definidas na Tabela 3. O indicador: OPAC corresponde à soma em módulo dos accruals discricionários dos três anos anteriores à medição do risco idiossincrático. Vale lembrar que a metodologia de obtenção dos accruals discricionários não se aplica às empresas do setor financeiro. Além disso, em função da mudança no padrão contábil brasileiro ${ }^{44}$ ocorrida em 2009 e implementada em 2010, não pôde ser avaliado o impacto da métrica: OPAC sobre o risco idiossincrático no período posterior a 2010.

Já os indicadores PEAD_1 e PEAD_2, que capturam as variações não esperadas nos preços das ações em decorrência do anúncio dos resultados anuais, são aplicáveis para empresas do setor financeiro e não financeiro.

$\mathrm{Na}$ Tabela 18 são apresentados os resultados da análise de regressão incluindo os indicadores de opacidade. Os valores da estatística t reportados foram ajustados à heterocedasticidade (erros robustos) após identificar a presença pelo teste de Breusch-Pagan/Cook-Weisberg. Como pode ser observado, a opacidade medida com base na soma dos accruals discricionários (OPAC) assim como as oscilações anormais nos retornos das ações (PEAD_1 e PEAD_2) não se mostraram significativas na explicação das variações do risco idiossincrático, na presença das demais variáveis. Tais resultados sugerem que a clareza na comunicação entre empresas e mercado não é um fator que, no Brasil, afete o comportamento do risco idiossincrático.

\footnotetext{
44 Detalhamento do impacto da mudança no padrão contábil sobre a construção do indicador está no tópico: ACCRUALS DISCRICIONÁRIOS COMO OPACIDADE CORPORATIVA OPAC.
} 


$$
\begin{aligned}
& I D I O \_1_{i, a}=\alpha+\beta_{1} C O N C_{-} 3_{i, a}+\beta_{2} L I Q_{i, a}+\beta_{3} M t B_{i, a}+\beta_{4} V M_{i, a}+\beta_{5} T_{U R N_{i, a}}+\beta_{6} E_{N D I V_{i, a}} \\
& +\beta_{7} R S P L_{i, a}+\beta_{8} O P A C_{i, a}+\beta_{9} P E A D_{-} 1_{i, a}+\beta_{10} P E A D_{-} 2_{i, a}+\beta_{11} D_{-} F I N_{i, a} \\
& +\varepsilon_{i, a} \\
& I D I O \_2_{i, a}=\alpha+\beta_{1} C O N C_{-} 3_{i, a}+\beta_{2} L I Q_{i, a}+\beta_{3} M t B_{i, a}+\beta_{4} V M_{i, a}+\beta_{5} T U R N_{i, a}+\beta_{6} E_{N D I V} \\
& +\beta_{7} R S P L_{i, a}+\beta_{8} \text { OPAC } C_{i, a}+\beta_{9} \text { PEAD_1 } 1_{i, a}+\beta_{10} \text { PEAD_2 } 2_{i, a}+\beta_{11} D_{-} F I N_{i, a} \\
& +\varepsilon_{i, a}
\end{aligned}
$$

\begin{tabular}{|c|c|c|c|c|c|c|c|c|c|c|c|c|c|c|c|c|}
\hline \multirow{2}{*}{$\begin{array}{c}\text { Equação } \\
\text { Variável } \\
\text { Intercepto }\end{array}$} & \multicolumn{2}{|c|}{$\begin{array}{c}67 \\
\text { IDIO_1 }\end{array}$} & \multicolumn{2}{|c|}{$\begin{array}{c}68 \\
\text { IDIO_2 }\end{array}$} & \multicolumn{2}{|c|}{$\begin{array}{c}67 \\
\text { IDIO_1 }\end{array}$} & \multicolumn{2}{|c|}{$\begin{array}{c}68 \\
\text { IDIO_2 }\end{array}$} & \multicolumn{2}{|c|}{$\begin{array}{c}67 \\
\text { IDIO_1 }\end{array}$} & \multicolumn{2}{|c|}{$\begin{array}{c}68 \\
\text { IDIO_2 }\end{array}$} & \multicolumn{2}{|c|}{$\begin{array}{c}67 \\
\text { IDIO_1 }\end{array}$} & \multicolumn{2}{|c|}{$\begin{array}{c}68 \\
\text { IDIO_2 }\end{array}$} \\
\hline & $\begin{array}{r}5,199 \\
(13,03)\end{array}$ & $* * *$ & $\begin{array}{r}5,541 \\
(14,25)\end{array}$ & $* * *$ & $\begin{array}{r}5,057 \\
(9,05)\end{array}$ & $* * *$ & $\begin{array}{r}5,484 \\
(10,43)\end{array}$ & $* * *$ & $\begin{array}{r}5,060 \\
(14,41)\end{array}$ & $* * *$ & $\begin{array}{r}5,519 \\
(15,24)\end{array}$ & $* * *$ & $\begin{array}{r}5,066 \\
(14,43)\end{array}$ & $* * *$ & $\begin{array}{r}5,522 \\
(15,26)\end{array}$ & $* * *$ \\
\hline OPAC & & & & & $\begin{array}{r}-0,213 \\
(-1,02)\end{array}$ & & $\begin{array}{r}0,017 \\
(0,08)\end{array}$ & & & & & & & & & \\
\hline PEAD_1 & & & & & & & & & $\begin{array}{r}-0,007 \\
(0,09)\end{array}$ & & $\begin{array}{r}-0,000 \\
(-0,01)\end{array}$ & & & & & \\
\hline$P E A D \_2$ & & & & & & & & & & & & & $\begin{array}{r}-0,001 \\
(-0,01)\end{array}$ & & $\begin{array}{r}0,005 \\
(0,04)\end{array}$ & \\
\hline D_FIN & & & & & & & & & $\begin{array}{r}-0,473 \\
(-4,56)\end{array}$ & $* * *$ & $\begin{array}{r}-0,356 \\
(-3,5)\end{array}$ & $* * *$ & $\begin{array}{c}-0,471 \\
(-4,54)\end{array}$ & $* * *$ & $\begin{array}{r}-0,355 \\
(-3,5)\end{array}$ & $* * *$ \\
\hline CONC_3 & $\begin{array}{r}0,179 \\
(3,85)\end{array}$ & $* * *$ & $\begin{array}{r}0,153 \\
(3,8)\end{array}$ & $* \star *$ & $\begin{array}{r}0,212 \\
(4,15)\end{array}$ & $* * *$ & $\begin{array}{r}0,196 \\
(3,85)\end{array}$ & $* \star *$ & $\begin{array}{r}0,175 \\
(4,29)\end{array}$ & $* * *$ & $\begin{array}{r}0,152 \\
(4,33)\end{array}$ & $* * *$ & $\begin{array}{r}0,175 \\
(4,3)\end{array}$ & $* * *$ & $\begin{array}{r}0,152 \\
(4,34)\end{array}$ & $* * *$ \\
\hline$L I Q$ & $\begin{array}{r}-0,153 \\
(-6,56)\end{array}$ & $* * *$ & $\begin{array}{r}-0,134 \\
(-6,38)\end{array}$ & $* * *$ & $\begin{array}{r}-0,158 \\
(-6,06)\end{array}$ & $* * *$ & $\begin{array}{r}-0,138 \\
(-5,84)\end{array}$ & $* * *$ & $\begin{array}{r}-0,177 \\
(-6,85)\end{array}$ & $* * *$ & $\begin{array}{r}-0,155 \\
(-6,31)\end{array}$ & $* * *$ & $\begin{array}{r}-0,177 \\
(-6,81)\end{array}$ & $* * *$ & $\begin{array}{r}-0,155 \\
(-6,28)\end{array}$ & $* * *$ \\
\hline$M t B$ & $\begin{array}{r}0,051 \\
(4,39)\end{array}$ & $* * *$ & $\begin{array}{r}0,043 \\
(3,83)\end{array}$ & $* * *$ & $\begin{array}{r}0,028 \\
(1,55)\end{array}$ & & $\begin{array}{r}0,038 \\
(2,06)\end{array}$ & ** & $\begin{array}{c}0,034 \\
(3,29)\end{array}$ & $* * *$ & $\begin{array}{r}0,028 \\
(2,8)\end{array}$ & $* * *$ & $\begin{array}{c}0,034 \\
(3,29)\end{array}$ & $* * *$ & $\begin{array}{r}0,028 \\
(2,8)\end{array}$ & $* * *$ \\
\hline$V M$ & $\begin{array}{r}-0,261 \\
(-9,52)\end{array}$ & $* * *$ & $\begin{array}{l}-0,290 \\
(-10,98)\end{array}$ & $* * *$ & $\begin{array}{r}-0,239 \\
(-6,26)\end{array}$ & $* * *$ & $\begin{array}{r}-0,280 \\
(-7,95)\end{array}$ & $* * *$ & $\begin{array}{l}-0,250 \\
(-10,24)\end{array}$ & $* * *$ & $\begin{array}{l}-0,287 \\
(-11,54)\end{array}$ & $* * *$ & $\begin{array}{l}-0,250 \\
(-10,26)\end{array}$ & $* * *$ & $\begin{array}{l}-0,287 \\
(-11,55)\end{array}$ & $* * *$ \\
\hline TURN & $\begin{array}{r}-0,033 \\
(-2,78)\end{array}$ & $* * *$ & $\begin{array}{r}-0,014 \\
(-1,25)\end{array}$ & & $\begin{array}{r}-0,018 \\
(-1,39)\end{array}$ & & $\begin{array}{r}0,000 \\
(0,03)\end{array}$ & & $\begin{array}{r}-0,040 \\
(-3,24)\end{array}$ & $* * *$ & $\begin{array}{r}-0,017 \\
(-1,49)\end{array}$ & & $\begin{array}{r}-0,040 \\
(-3,24)\end{array}$ & $* * *$ & $\begin{array}{r}-0,018 \\
(-1,5)\end{array}$ & \\
\hline ENDIV & $\begin{array}{r}-0,032 \\
(-2,14)\end{array}$ & ** & $\begin{array}{r}-0,039 \\
(-2,78)\end{array}$ & $* * *$ & $\begin{array}{r}-0,025 \\
(-1,6)\end{array}$ & & $\begin{array}{r}-0,034 \\
(-2,41)\end{array}$ & ** & & & & & & & & \\
\hline$R S P L$ & $\begin{array}{r}-0,003 \\
(-1,48)\end{array}$ & & $\begin{array}{r}0,004 \\
(2,01)\end{array}$ & ** & $\begin{array}{r}0,000 \\
(0,17)\end{array}$ & & $\begin{array}{r}0,005 \\
(2,00)\end{array}$ & ** & & & & & & & & \\
\hline$N$ & 965 & & 908 & & 560 & & 534 & & 1,026 & & 969 & & 1,026 & & 969 & \\
\hline $\mathrm{R} 2$ & 0,2815 & & 0,3022 & & 0,3021 & & 0,3263 & & 0,3131 & & 0,3358 & & 0,3132 & & 0,336 & \\
\hline
\end{tabular}

Tabela 18: Efeito da opacidade corporativa sobre o risco idiossincrático,

Os números entre parêntesis correspondem à estatística t ajustada para correção da heterocedasticidade. Foram excluídas as observações que geraram resíduos discrepantes. Os sinais: * ${ }^{* *} e^{* * *}$ correspondem os níveis de significância $10 \% ; 5 \%$ e $1 \%$ respectivamente. As variáveis utilizadas estão descritas na Tabela 3 . Os resultados das regressões utilizando a métrica IDIO_3 foram omitidos tendo em vista que os resultados foram quase idênticos àqueles obtidos com a medida IDIO_1. 
Vale lembrar que as métricas que avaliaram a clareza na comunicação entre empresa e mercado: accruals discricionários e post earning announcement drift (PEAD) utilizam abordagens distintas. Os accurals discricionários relacionamse com as escolhas contábeis relativas à contabilização pelo regime de competência como depreciação e recebíveis; enquanto as oscilações de preços das ações em torno do anúncio anual de resultado (PEAD) refletem a percepção do investidor, traduzida em preço, das informações levadas ao mercado, com ênfase na medida do lucro.

Em comum, as duas abordagens estão apoiadas nas informações passadas que, com base na teoria econômica, servem de base para a projeção das expectativas dos resultados futuros por investidores racionais.

Dessa forma, as evidências sugerem que se o risco idiossincrático é resultado da incorporação de informações específicas nos preços, não parecem ser prioritariamente as informações divulgadas pela empresa ao mercado que promovem as variações, Ou seja, as informações são incorporadas por outros mecanismos. Isso porque o resultado da aplicação de duas metodologias distintas, centradas na comunicação das informações sobre a estimativa do desempenho (qual seja, o lucro), indica que o risco idiossincrático e a comunicação entre empresa e mercado não estão relacionadas. Também é razoável supor que ao menos em parte, as variações dos retornos idiossincráticos sejam resultado da atuação noise traders.

Ainda assim, foram analisadas as igualdades das médias dos indicadores de risco idiossincrático (IDIO_1, IDIO_2 e IDIO_3) para subamostras com base nos quartis de cada uma das medidas de opacidade (OPAC, PEAD_1 e PEAD_2), conforme demonstrado na Figura 8. Não foram observadas diferenças significativas entre as médias, confirmando as evidências da não significância da relação entre risco idiossincrático e as métricas que avaliam a opacidade e, por complementariedade, a transparência corporativa.

Na Tabela 19 estão demonstradas as estatísticas descritivas dos valores de IDIO_1 e IDIO_2 para as subamostras organizadas por quartis das medidas de opacidade: OPAC, PEAD_1 e PEAD_2. 


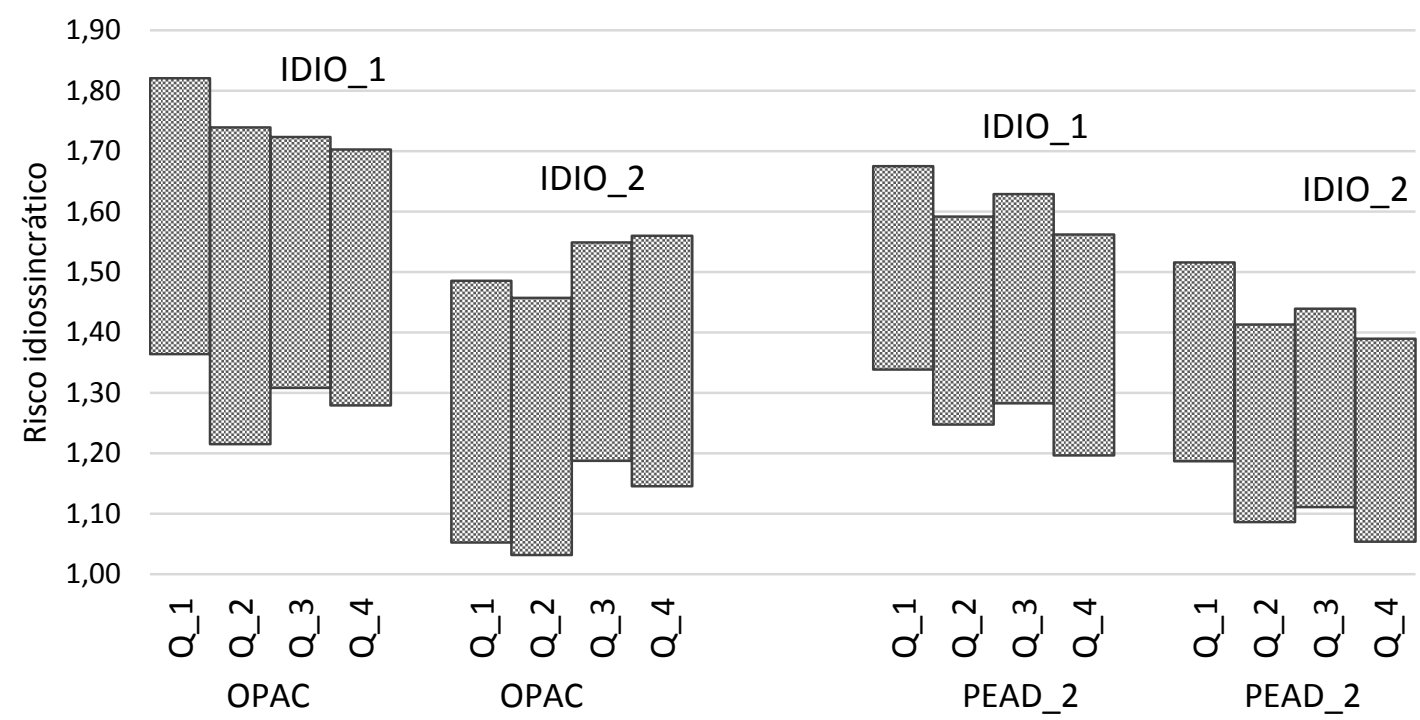

Figura 8: Intervalo de confiança para a média de IDIO_1 por quartil de OPAC e de PEAD_2. As subamostras foram organizadas por quartis das medidas OPAC e PEAD. Os resultados para IDIO_3 foram omitidos tendo em vista que praticamente não diferem dos resultados obtidos para IDIO_1. Q_n indica que as observações foram agrupadas por quartis dos valores da variável indicada.

Tabela 19: Estatística descritiva das submostras organizadas por quatis de OPAC, PEAD_1 e PEAD_2

\begin{tabular}{|c|c|c|c|c|c|c|}
\hline $\begin{array}{l}\text { PEAD_2 e } \\
\text { IDIO_1 }\end{array}$ & $\begin{array}{l}\text { Número de } \\
\text { Observações }\end{array}$ & $\begin{array}{l}\text { Valor médio } \\
\text { IDIO_1 }\end{array}$ & $\begin{array}{l}\text { Desvio } \\
\text { Padrão }\end{array}$ & $\begin{array}{l}\text { Coeficiente de } \\
\text { variação }\end{array}$ & \multicolumn{2}{|c|}{$\begin{array}{c}\text { Intervalo de Confiança } \\
(95 \%)\end{array}$} \\
\hline PEAD_2 Q1 & 264 & 1,507 & 1,390 & 0,922 & 1,339 & 1,675 \\
\hline PEAD_2 Q2 & 263 & 1,420 & 1,415 & 0,997 & 1,248 & 1,592 \\
\hline PEAD_2 Q3 & 264 & 1,456 & 1,430 & 0,982 & 1,283 & 1,629 \\
\hline PEAD_2Q4 & 262 & 1,380 & 1,502 & 1,088 & 1,197 & 1,562 \\
\hline $\begin{array}{l}\text { PEAD_2 e } \\
\text { IDIO_2 }\end{array}$ & $\begin{array}{l}\text { Número de } \\
\text { Observações }\end{array}$ & $\begin{array}{l}\text { Valor médio } \\
\text { IDIO_2 }\end{array}$ & $\begin{array}{l}\text { Desvio } \\
\text { Padrão }\end{array}$ & $\begin{array}{l}\text { Coeficiente de } \\
\text { variação }\end{array}$ & \multicolumn{2}{|c|}{$\begin{array}{c}\text { Intervalo de Confiança } \\
(95 \%)\end{array}$} \\
\hline PEAD_2 Q1 & 252 & 1,352 & 1,325 & 0,980 & 1,187 & 1,516 \\
\hline PEAD_2 Q2 & 248 & 1,250 & 1,308 & 1,047 & 1,086 & 1,413 \\
\hline PEAD_2 Q3 & 243 & 1,275 & 1,297 & 1,017 & 1,111 & 1,439 \\
\hline PEAD_2Q4 & 247 & 1,222 & 1,340 & 1,096 & 1,054 & 1,390 \\
\hline $\begin{array}{l}\text { OPAC e } \\
\text { IDIO_1 }\end{array}$ & $\begin{array}{l}\text { Número de } \\
\text { Observações }\end{array}$ & $\begin{array}{l}\text { Valor médio } \\
\text { IDIO_1 }\end{array}$ & $\begin{array}{l}\text { Desvio } \\
\text { Padrão }\end{array}$ & $\begin{array}{l}\text { Coeficiente de } \\
\text { variação }\end{array}$ & \multicolumn{2}{|c|}{$\begin{array}{c}\text { Intervalo de Confiança } \\
(95 \%)\end{array}$} \\
\hline OPAC Q1 & 151 & 1,593 & 1,420 & 0,891 & 1,364 & 1,821 \\
\hline OPAC Q2 & 152 & 1,477 & 1,635 & 1,107 & 1,215 & 1,739 \\
\hline OPAC Q3 & 152 & 1,516 & 1,297 & 0,855 & 1,308 & 1,724 \\
\hline OPAC Q4 & 150 & 1,491 & 1,312 & 0,879 & 1,280 & 1,703 \\
\hline $\begin{array}{l}\text { OPAC e } \\
\text { IDIO_2 }\end{array}$ & $\begin{array}{l}\text { Número de } \\
\text { Observações }\end{array}$ & $\begin{array}{l}\text { Valor médio } \\
\text { IDIO_2 }\end{array}$ & $\begin{array}{l}\text { Desvio } \\
\text { Padrão }\end{array}$ & $\begin{array}{l}\text { Coeficiente de } \\
\text { variação }\end{array}$ & \multicolumn{2}{|c|}{$\begin{array}{c}\text { Intervalo de Confiança } \\
(95 \%)\end{array}$} \\
\hline OPAC Q1 & 134 & 1,269 & 1,267 & 0,998 & 1,053 & 1,485 \\
\hline OPAC Q2 & 145 & 1,245 & 1,297 & 1,042 & 1,032 & 1,457 \\
\hline OPAC Q3 & 149 & 1,369 & 1,115 & 0,815 & 1,188 & 1,549 \\
\hline OPAC Q4 & 144 & 1,353 & 1,258 & 0,930 & 1,146 & 1,560 \\
\hline
\end{tabular}

A tabela demonstra as estatísticas descritivas dos valores de IDIO_1 e IDIO_2 para as subamostras organizadas por quartis das medidas de opacidade: OPAC , PEAD_1 e PEAD_2, 


\section{CONCLUSÕES E CONSIDERAÇÕES FINAIS}

O objetivo principal desse trabalho foi avaliar o papel da concentração de acionária sobre o risco idiossincrático no ambiente brasileiro, caracterizado por elevada concentração dos direitos de propriedade. Vale lembrar que o contexto brasileiro difere do que se observa no ambiente acionário anglo-saxão onde em geral o controle acionário é pulverizado e a gestão é separada do controle. Também foi avaliada a relação entre o risco idiossincrático e a clareza na comunicação entre empresa e mercado considerando que a concentração de propriedade afeta os incentivos relacionados à divulgação de informaçõe e, consequentemente, o ambiente informacional das empresas.

A concentração dos direitos de propriedade foi medida com base na abordagem da participação sobre o total das ações do maior acionista e também considerando o percentual conjunto dos três maiores acionistas. Em média, o maior acionista entre as empresas analisadas detém aproximadamente um terço do total das ações e os três maiores acionistas detém, em média, mais da metade. Tais percentuais não se alteraram significativamente ao longo do período analisado. Embora o mercado de capitais brasileiro tenha verificado importante crescimento entre 2002 e 2012, evidenciado inclusive pelo número de empresas que compuseram a amostra a cada ano, a concentração acionária em relação aos direitos de propriedade das empresas estudadas não apresentou variação significativa nesse período.

No aspecto do ambiente informacional, foram utilizadas duas abordagens distintas para investigar se o risco idiossincrático poderia ser explicado pela incorporação, nos preços das ações, das informações específicas divulgadas de maneira clara (transparente) pelas empresas. Uma delas se apoia na quantificação dos accruals discricionários, os quais, segundo a literatura, podem ser considerados como proxy da opacidade dos lucros e, consequentemente espelha a não-transparência das informações sobre o lucro divulgado. Outra métrica aplicada neste estudo e que também reflete a qualidade da comunicação entre empresa e mercado foi a dimensão das oscilações dos preços das ações em torno do anúncio de resultados anuais. Foi obtida com base no post earning announcement drift (PEAD), sob o 
entendimento de que as informações contábeis obrigatórias têm um papel confirmatório das informações tempestivamente divulgadas pelas empresas. Portanto, a oscilação dos preços das ações em torno da divulgação de resultados corresponde à precificação das novas informações que afetam a expectativa de desempenho futuro e que foram divulgadas quando da publicação dos relatórios auditados. Então a dimensão da oscilação do preço em torno da data da divulgação dos relatórios financeiros obrigatórios indicam o grau de não-transparência (opacidade) da empresa na divulgação tempestiva dos aspectos relativos à atividade e desempenho da empresa.

O risco idiossincrático foi mensurado a partir do coeficiente de determinação da regressão dos retornos da ação da empresa sobre os retornos dos fatores sistemáticos. O risco idiossincrático $\left(1-R^{2}\right)$, nessa abordagem, corresponde ao complemento do coeficiente de determinação da regressão $\left(R^{2}\right)$, e indica o percentual das variações dos retornos da ação que não estão sincronizados com as variações do retorno do mercado. Foram usados três modelos: modelo de mercado em que a variável independente é o retorno do IBRX, modelo em que além do IBRX foi usado o retorno do índice S\&P 500 como variável independente. O terceiro modelo usado foi o CAPM. Em média, os coeficientes de determinação $\left(R^{2}\right)$ do modelo que incluiu o retorno do índice S\&P 500 foram superiores aos $\mathrm{R}^{2}$ dos modelos em que os retornos das ações eram explicados somente pelo retorno do IBRX.

Verificou-se que a concentração de propriedade esteve positivamente relacionada com o risco idiossincrático, considerando tanto a participação do maior acionista quanto dos três maiores acionistas: A medida em que aumenta a participação acionária, o risco idiossincrático cresce. Contudo, quando os três maiores acionistas detém mais de $70 \%$ das ações da empresa, o aumento na participação acionária não afetou o risco idiossincrático. Porém, o risco idiossincrático médio das empresas em que os três maiores acionistas detém mais de $70 \%$ das ações foi significativamente maior quando comparado às demais empresas.

Foram encontradas evidências da relação positiva entre a rentabilidade do patrimônio líquido e o risco idiossincrático no grupo de empresas com alta 
concentração acionária ${ }^{45}$. Para as demais empresas, as oportunidades de crescimento, medida pela relação entre o valor de mercado das ações e 0 patrimônio líquido (MtB) e o endividamento foram relevantes na explicação das variações do risco idiossincrático: o endividamento reduzindo $e$ as oportunidades de crescimento aumentando o risco idiossincrático.

As oportunidades de crescimento podem gerar divergências entre os investidores sobre as expectativas de desempenho futuro, compatível com a suposição de que o risco idiossincrático reflete, em parte, as informações específicas incorporadas aos preços. Além disso, entre as empresas com alta concentração acionária, as do setor financeiro têm em média menor risco idiossincrático do que as não financeiras. Outra diferença que merece ser destacada é que para empresas com menor concentração acionária, o endividamento afetou negativamente o risco idiossincrático.

Já os resultados das análises envolvendo variáveis que capturam a opacidade (ou o complemento: clareza) na comunicação entre empresas e mercado não confirmaram a hipótese de que a transparência corporativa está relacionada com o risco idiossincrático e, consequentemente, com a sincronicidade. Tais resultados são compatíveis com outros estudos como aquele conduzido por Datta et al,(2014).

Confirmou-se que o risco idiossincrático está relacionado com a concentração acionária mas as evidências não são conclusivas para considerar que o risco idiossincrático corresponde às informações específicas incorporadas aos preços, sobretudo quando parcela considerável das ações totais da empresa estão em mãos de poucos acionistas. Embora a literatura indique que o aumento da concentração acionária aumenta os incentivos ao monitoramento das atitudes dos gestores, essa abordagem foi teorizada em um ambiente em que os direitos de propriedade são pulverizados e o conflito de agência é entre o acionista (proprietário) e o gestor, característico dos mercados em economias de origem anglo-saxãs. Num cenário em que os direitos de propriedade estão

\footnotetext{
45 Alta concentração acionária refere-se às subamostras das empresas em que o maior acionista detém mais de $50 \%$ do total das ações e/ou os três maiores acionistas detém mais de $70 \%$ do total das ações
} 
altamente concentrados como no Brasil, em que parcela importante das empresas são controladas por um pequeno grupo de acionistas, o conflito se dá entre os acionistas controladores e os acionistas minoritários. Dessa forma, se os grandes acionistas têm maior poder de decisão sobre os fluxos de caixa, reduzem-se os incentivos para a disseminação de informações específicas para o mercado. Nesse sentido, seria esperado que a concentração acionária favorecesse a incorporação de informações nos preços até certo ponto de concentração, a partir da qual os grandes acionistas não teriam incentivos para divulgar informações sobre as atividades da empresa. Tampouco o grande acionista teria vantagem na incorporação das informações específicas aos preços.

Contudo, analisando sob um outro enfoque, os grandes acionistas podem ter interesse em negociar parte das suas ações quando os preços estiverem diferentes daquele que corresponde ao valor presente das expectativas futuras. Os grandes acionistas teriam incentivos para adquirir as ações da própria empresa, ou influenciar a recompra das ações pela própria empresa quando as ações estivessem subavaliadas em relação às expectativas dos projetos futuros. Como o grande acionista tem informações completas sobre os projetos que serão realizados, a assimetria informacional tenderia a zero para o grande acionista controlador. A recompra das próprias ações ou a aquisição das ações pelos grandes acionistas sinalizaria o mercado sobre as mudanças nas expectativas futuras da empresa, fazendo com que o preço se ajustasse às informações detidas pelo grande acionista, mesmo que não fossem divulgadas ao mercado.

Analogamente, quando o preço da ação está acima daquele que corresponde ao valor presente das expectativas futuras do ponto de vista do grande acionista, este tem incentivos para se desfazer de uma parte das ações e realizar o lucro correspondente à diferença entre o preço de mercado e o valor estimado pelo grande acionista. Esse movimento de venda das ações provocaria um aumento da oferta, ajustando o preço da ação para baixo. Então as informações sobre o desempenho futuro seriam incorporadas aos preços e, também nesse caso, sem que os gestores divulgassem as informações específicas ao mercado. 
Então, no Brasil, economia caracterizada pela alta concentração acionária, as evidências sugerem que, na hipótese do risco idiossincrático estar relacionado às informações específicas incorporadas aos preços, essas informações incorporadas não aparentam ser aquelas divulgadas voluntariamente pela empresa como resultado da clareza na comunicação entre a empresa e o mercado.

Ao menos em parte, as oscilações de preços parecem corresponder aos retornos específicos decorrentes da atuação dos grandes acionistas ofertando ou retirando ações do mercado e, consequentemente, alterando o preço na direção de um novo equilíbrio, refletindo ou informações ou a atuação oportunista por parte dos mesmos. Porém, foram encontradas evidências de que parcela do risco idiossincrático das ações das empresas com elevada concentração acionária não decorre da incorporação de informações específicas nos preços mas reflete a baixa liquidez em bolsa consequente da menor disponibilidade do ativo no mercado.

Dessa maneira, os achados indicam que para compreender a relação entre o risco idiossincrático e as informações específicas incorporadas aos preços é necessário ampliar o conhecimento sobre os incentivos que grandes acionistas têm para ajustar os preços às expectativas futuras de desempenho. Um aspecto que merece ser aprofundado é o estudo das operações de compra e venda de ações envolvendo pessoas que, em virtude de fatos circunstanciais têm acesso a informações relevantes sobre os negócios e situação da companhia.

Além disso, várias empresas no Brasil pertencem a grupos econômicos de estrutura piramidal, cabendo, assim, analisar a influência dessa estrutura no comportamento dos retornos específicos os quais são a origem do risco idiossincrático. 


\section{LIMITAÇÕES E DELIMITAÇÕES DO ESTUDO}

Uma importante limitação do estudo que deve ser assinalada é o fato de que o grau transparência corporativa não pode ser observado diretamente, havendo

a necessidade de se valer de modelos que não captam toda a complexidade daquilo que a teoria financeira entende por transparência. Além disso, a própria definição não é consensual entre os autores permitindo, pois, algumas interpretações válidas, fato que aumenta a subjetividade dos modelos aplicados.

Um aspecto importante da estrutura de propriedade que não foi abordado nesta pesquisa refere-se ao impacto sobre o ambiente informacional da parcela dos direitos de propriedade detidos por parte dos administradores, denominado insider ownership na língua inglesa. A inexistência de dados diretos referentes a essa informação bem como a dificuldade da obtenção e identificação dos dados que correspondem a esse aspecto pelos relatórios da Comissão de Valores Mobiliários não permitiram a análise do impacto do insider ownership sobre o risco idiossincrático neste estudo.

Outra limitação importante está no fato de que os fenômenos financeiros e o comportamento do mercado são analisados por meio de modelos econômicos e econométricos que partem de pressupostos como a racionalidade do investidor, além de postularem que os investidores maximizam sua utilidade em função do risco e que os mercados são eficientes na forma forte. Tais proposições nem sempre são confirmadas empiricamente de forma inequívoca (Ryan, Scapens, \& M., 2002, p. 51). 


\section{REFERÊNCIAS}

Ackert, L., \& Deaves, R. (2009). Behavioral finance: Psychology, decisionmaking, and markets. South-Western Pub.

Akerlof, G. A. (1970). The Market For "Lemons": Quality Uncertainty And The Market Mechanism. Quarterly Journal Of Economic, 84(3), 488-500.

Aldrighi, D. M., Antonio, F., \& Postali, S. (2011). Propriedade Piramidal das Empresas no Brasil. Revista EconomiA, Brasília(DF), 12(1), 27-48.

Alencar, R. (2007). Nível de disclosure e custo de capital próprio no mercado brasileiro. Tese (Doutorado em Controladoria e Contabilidade) Faculdade de Economia, Administração e Contabilidade, Universidade de São Paulo, São Paulo, São Paulo.

Ali, A., Hwang, L.-S., \& Trombley, M. A. (2003). Arbitrage risk and the book-tomarket anomaly. Journal of Financial Economics, 69(2), 355-373. doi:http://dx.doi.org/10.1016/S0304-405X(03)00116-8

Alves, P., Peasnell, K., \& Taylor, P. (2010). The Use of the R2 as a Measure of Firm-Specific Information: A Cross-Country Critique. Journal of Business Finance \& Accounting, 37(1-2), 1-26. doi:10.1111/j.14685957.2009.02181.x

An, H., Cook, D. O., \& Zumpano, L. V. (2011). Corporate Transparency and Firm Growth: Evidence from Real Estate Investment Trusts. Real Estate Economics, 39(3), 429-454. doi:10.1111/j.1540-6229.2010.00299.x

An, H., \& Zhang, T. (2013). Stock price synchronicity, crash risk, and institutional investors. Journal of Corporate Finance, 21(0), 1-15. doi:http://dx.doi.org/10.1016/j.jcorpfin.2013.01.001

Ang, A., Hodrick, R. J., Xing, Y., \& Zhang, X. (2006). The Cross-Section of Volatility. The Journal of Finance, LXI(1), 259-299.

Arena, M. P., Haggard, K. S., \& Yan, X. (Sterling). (2008). Price Momentum and Idiosyncratic Volatility. Financial Review, 43(2), 159-190. doi:10.1111/j.1540-6288.2008.00190.x

Argolo, É. F. B., Leal, R. P. C., \& Almeida, V. de S. e. (2012). O modelo de Fama e French é aplicável no Brasil? Relatórios COPPEAD - UFRJ, 402, 27.

Armstrong, C. S., Balakrishnan, K., \& Cohen, D. (2012). Corporate governance and the information environment: Evidence from state antitakeover laws. Journal of Accounting and Economics, 53(1-2), 185-204. doi:10.1016/j.jacceco.2011.06.005 
Armstrong, C. S., Core, J. E., Taylor, D. J., \& Verrecchia, R. E. (2011). When Does Information Asymmetry Affect the Cost of Capital? Journal of Accounting Research, 49(1), 1-40. doi:10.1111/j.1475-679X.2010.00391.x

Arya, A., Glover, J., Mittendorf, B., \& Zhang, L. (2004). The Disciplining Role of Accounting in the Long-Run. Review of Accounting Studies, 9(4), 399-417. doi:10.1007/s11142-004-7790-x

Ashbaugh-skaife, H., Gassen, J., \& LaFond, R. (2005). Does Stock Price Synchronicity Represent Firm-Specific Information? The International Evidence. MIT Sloan Research Paper (Vol. 4551-05). Retrieved from http://dx.doi.org/10.2139/ssrn.768024

Bali, T. G., \& Cakici, N. (2009). Idiosyncratic Volatility and the Cross Section of Expected Returns. Journal of Financial and Quantitative Analysis, 43(01), 29. doi:10.1017/S002210900000274X

Bali, T. G., Cakici, N., Zhang, Z., \& Xuemin Yan, (Sterling). (2005). Does Idiosyncratic Risk Really Matter? Journal of Finance, 60(2), 905-929. Retrieved from 10.1111/j.1540-6261.2005.00750.x

Ball, R. (1978). Anomalies in relationships between securities' yields and yieldsurrogates. Journal of Financial Economics, 6(2-3), 103-126. doi:http://dx.doi.org/10.1016/0304-405X(78)90026-0

Ball, R. (1992). The earnings-price anomaly. Journal of Accounting and Economics, 15(2-3), 319-345. doi:http://dx.doi.org/10.1016/01654101(92)90023-U

Ball, R., \& Brown, P. (1968). An Empirical Evaluation of Accounting Income Numbers. Journal of Accounting Research, 6(2), 159-178.

Ball, R., Jayaraman, S., \& Shivakumar, L. (2006). The Role of Accruals in Asymmetrically Timely Gain and Loss Recognition. Journal of Accounting Research, 44(2), 207-242. Retrieved from 10.1111/j.1475679X.2006.00198.x

Ball, R., Jayaraman, S., \& Shivakumar, L. (2012). Audited financial reporting and voluntary disclosure as complements: $A$ test of the Confirmation Hypothesis. Journal of Accounting and Economics, 53(1-2), 136-166. doi:http://dx.doi.org/10.1016/j.jacceco.2011.11.005

Barberis, N., Shleifer, A., \& Wurgler, J. (2005). Comovement. Journal of Financial Economics (Vol. 75, pp. 283-317). doi:10.1016/j.jineco.2004.04.003

Bartram, S. M. S. M., Brown, G., \& Stulz, R. M. (2012). Why Are U . S . Stocks More Volatile? The Journal of Finance, LXVII(4). Retrieved from http://www.ssrn.com/abstract $=1769207$ 
Basu, S. (1983). The relationship between earnings' yield, market value and return for NYSE common stocks: Further evidence. Journal of Financial Economics, 12(1), 129-156. doi:http://dx.doi.org/10.1016/0304405X(83)90031-4

Basu, S., Markov, S., \& Shivakumar, L. (2009). Inflation, earnings forecasts, and post-earnings announcement drift. Review of Accounting Studies, 15(2), 403-440. doi:10.1007/s11142-009-9112-9

Bencivenga, V. R., \& Smith, B. D. (1991). Financial Intermediation and Endogenous Growth. Review of Economic Studies, 58(2), 195-209. Retrieved from http://search.ebscohost.com/login.aspx?direct=true\&db=eoh\&AN=024943 $3 \&$ lang=pt-br\&site $=$ ehost-live

Bencivenga, V. R., Smith, B. D., \& Starr, R. M. (1996). Equity Markets, Transactions Costs, and Capital Accumulation: An Illustration. The World Bank Economic Review, 10(2), 241-265. Retrieved from http://wber.oxfordjournals.org/content/10/2/241.abstract

Beniluz, Y. (2005). The Confirmatory Role of Mandatory Accounting: Accounting as a Disciplinary Mechanism for Managers 'Estimates and Analysts 'Forecasts. Working Paper Series WCRFS: 06-15 (pp. 6-15).

Bernard, V. L., \& Thomas, J. K. (1989). Post-Earnings-Announcement Drift: Delayed Price Response or Risk Premium? Journal of Accounting Research, 27(3), 1-36. Retrieved from http://search.ebscohost.com/login.aspx?direct=true\&db=bth\&AN=641469 1 \&lang=pt-br\&site=ehost-live

Bernard, V. L., \& Thomas, J. K. (1990). Evidence That Stock Prices Do Not Fully Reflect The Implications Of Current Earnings For Future Earnings. Journal of Accounting and Economics, 13, 305-340.

Berry, T. K., Paige Fields, L., \& Wilkins, M. S. (2006). The interaction among multiple governance mechanisms in young newly public firms. Journal of Corporate Finance, 12(3), 449-466. doi:10.1016/j.jcorpfin.2005.08.003

Bissessur, S., \& Hodgson, A. (2012). Stock market synchronicity - an alternative approach to assessing the information impact of Australian IFRS. Accounting \& Finance, 52(1), 187-212. doi:10.1111/j.1467629X.2010.00388.x

Black, F. (1986). Noise. The Journal of Finance, XL/(3), 529-543.

Bloomfield, R., Hara, M. O., \& O'Hara, M. (1999). Market Transparency: Who Wins and Who Loses? Review of Financial Studies, 12(1), 5-35. Retrieved from http://rfs.oxfordjournals.org 
Bodie, Z., Kane, A., \& Marcus, A. J. (2007). Fundamentos de investimentos. Bookman.

Bondt, W. F. M. De, \& Thaler, R. H. (1987). Further Evidence on Investor Overreaction and Stock Market Seasonality. The Journal of Finance, 42(3), 557-581. doi:10.2307/2328371

Bornholt, G. (2007). Extending the capital asset pricing model: the reward beta approach. Accounting \& Finance, 47(1), 69-83. Retrieved from 10.1111/j.1467-629X.2007.00202.x

Bortolon, P. M. (2012). Por que as empresas brasileiras adotam estruturas piramidais de controle. BASE - Revista de Administração E Contabilidade Da Unisinos, 10(1), 2-18. doi:10.4013/base.2013.101.01

Boscov, C. (2011). Uma Análise sobre a Relação entre Rentabilidade e as Empresas Abertas Vencedoras do Troféu Transparência. Title. Administração de Empresas Em Revista, $x(1-20)$.

Boubaker, S., Mansali, H., \& Rjiba, H. (2014). Large controlling shareholders and stock price synchronicity. Journal of Banking \& Finance, 40, 80-96. doi:10.1016/j.jbankfin.2013.11.022

Boyd, J. H., \& Prescott, E. C. (1986). Financial intermediary-coalitions. Journal of Economic Theory, 38(2), 211-232. doi:http://dx.doi.org/10.1016/00220531(86)90115-8

Brandt, M. W., Brav, a., Graham, J. R., \& Kumar, a. (2009). The Idiosyncratic Volatility Puzzle: Time Trend or Speculative Episodes? Review of Financial Studies, 23(2), 863-899. doi:10.1093/rfs/hhp087

Brockman, P., Liebenberg, I., \& Schutte, M. (2010). Comovement, information production, and the business cycle. Journal of Financial Economics, 97(1), 107-129. doi:10.1016/j.jfineco.2010.03.008

Brockman, P., \& Yan, X. (Sterling). (2009). Block ownership and firm-specific information. Journal of Banking \& Finance, 33(2), 308-316. doi:10.1016/j.jbankfin.2008.08.011

Brown, G., \& Kapadia, N. (2007). Firm-specific risk and equity market development. Journal of Financial Economics, 84(2), 358-388. doi:10.1016/j.jineco.2006.03.003

Brown, P., \& Kennelly, J. W. (1972). The Informational Content of Quarterly Earnings: An Extension and Some Further Evidence. The Journal of Business, 45(3), 403-415 CR - Copyright \&\#169; 1972 The University . doi: $10.2307 / 2351496$ 
Bushee, B. J., \& Noe, C. F. (2000). Corporate Disclosure Practices, Institutional Investors, and Stock Return Volatility. Journal of Accounting Research, 38, 171. doi:10.2307/2672914

Bushman, R., Chen, Q., Engel, E., \& Smith, A. (2004). Financial accounting information, organizational complexity and corporate governance systems. Journal of Accounting and Economics (Vol. 37, pp. 167-201). doi:10.1016/j.jacceco.2003.09.005

Bushman, R. M., Piotroski, J. D., \& Smith, A. J. (2004). What Determines Corporate Transparency? Journal of Accounting Research, 42(2), 207252.

Bushman, R. M., \& Smith, A. J. (2003). Transparency, Financial Accounting Information, and Corporate Governance. FRBNY Economic Policy Review, (April), 65-87.

Campbell, J. Y., Lettau, M., Malkiel, B. G., \& Xu, Y. (2001). Have Individual Stocks Become More Volatile? An Empirical Exploration of Idiosyncratic Risk. The Journal of Finance, LVI(1).

Cao, C., Simin, T., \& Zhao, J. (2006). Can Growth Options Explain the Trend in Idiosyncratic Risk? Review of Financial Studies, 21(6), 2599-2633. doi:10.1093/rfs/hhl039

Cao, S. S., \& Narayanamoorthy, G. S. (2012). Earnings Volatility, Post-Earnings Announcement Drift, and Trading Frictions. Journal of Accounting Research, 50(1), 41-74. Retrieved from 10.1111/j.1475679X.2011.00425.x

Carvalhal-da-Silva, A. L. (2004). Governança corporativa, valor, alavancagem e poítica de dividendos das empresas brasileiras. Revista de Administraçao Da Da Universidade de São Paulo, 39(4).

Chan, K., \& Hameed, A. (2006). Stock price synchronicity and analyst coverage in emerging markets. Journal of Financial Economics, 80(1), 115-147. doi:10.1016/j.jineco.2005.03.010

Chan, K., Hameed, A., \& Kang, W. W. (2013). Stock Price Synchronicity and Liquidity. Journal of Financial Markets, 16(3), 414-438. doi:10.1016/j.finmar.2012.09.007

Chen, C., Huang, A. G., \& Jha, R. (2012). Idiosyncratic Return Volatility and the Information Quality Underlying Managerial Discretion. Journal of Financial and Quantitative Analysis, 47(04), 873-899. doi:10.1017/S002210901200018X

Chen, N.-F., Roll, R., \& Ross, S. A. (1986). Economic Forces and the Stock Market. The Journal of Business, 59(3), 383-403. doi:10.2307/2352710 
Chen, Q., Goldstein, I., \& Jiang, W. (2007). Price Informativeness and Investment Sensitivity to Stock Price. Review of Financial Studies, 20(3), 619-650. doi:10.1093/rfs/hhl024

Chen, Z., \& Petkova, R. (2012). Does Idiosyncratic Volatility Proxy for Risk Exposure? Review of Financial Studies, 25(9), 2745-2787. doi:10.1093/rfs/hhs084

Chun, H., Kim, J., Morck, R., \& Yeung, B. (2008). Creative destruction and firmspecific performance heterogeneity. Journal of Financial Economics, 89(1), 109-135. doi:10.1016/j.jfineco.2007.06.005

Claessens, S., Djankov, S., Fan, J. P. H., \& Lang, L. H. P. (2002). Disentangling the Incentive and Entrenchment Effects of Large Shareholdings. The Journal of Finance, LVII(6), 2741-2771.

Collins, D. W., Kothari, S. P., Shanken, J., \& Sloan, R. G. (1994). Lack of timeliness and noise as explanations for the low contemporaneous returnearnings association. Journal of Accounting and Economics, 18, 289-324.

Courtault, J.-M., Kabanov, Y., Bru, B., Crépel, P., Lebon, I., \& Le Marchand, A. (2000). Louis Bachelier on the Centenary of Théorie de la Spéculation. Mathematical Finance, 10(3), 339-353. doi:10.1111/1467-9965.00098

Cremers, K. J. M., \& Nair, V. . B. (2005). Governance Mechanisms and Equity Prices. The Journal of Finance, 60(6), 2859-2894.

Danbolt, J., Hirst, I. R. C., \& Jones, E. (2011). The growth companies puzzle: can growth opportunities measures predict firm growth? European Journal of Finance, 44(0), 1-45.

Dantas, J. A. et al. (2008). A dualidade entre os benefícios do disclosure e a relutância das organizações em aumentar o grau de evidenciação. Revista Economia \& Gestão, 5(11), 56-76.

Dasgupta, S., Gan, J., \& Gao, N. (2010). Transparency, Price Informativeness, and Stock Return Synchronicity: Theory and Evidence. Journal of Financial and Quantitative Analysis, 45(05), 1189-1220. doi:10.1017/S0022109010000505

Datta, S., Iskandar-Datta, M., \& Singh, V. (2014). Opaque financial reports and R2: Revisited. Review of Financial Economics, 23(1), 10-17. doi:10.1016/j.rfe.2013.08.001

Davies Junior, C., \& Brito, S. (2010). Análise Quantitativa da Correlação entre os Índices S\&P 500 e lbovespa. Estudos Em Finanças: Investimentos, 13.

Dechow, P. M. (1994). Accounting earnings and cash flows as measures of firm performance: The role of accounting accruals. Journal of Accounting and 
Economics, 18(1), 3-42. doi:http://dx.doi.org/10.1016/01654101(94)90016-7

Dechow, P. M., \& Skinner, D. J. (2000). Earnings Management: Reconciling the Views of Accounting Academics, Practitioners, and Regulators. Accounting Horizons, 14(2), 235-250. Retrieved from http://search.ebscohost.com/login.aspx?direct=true\&db=buh\&AN=335810 9\&lang=pt-br\&site=ehost-live

Dechow, P. M., Sloan, R. G., \& Sweeney, A. P. (1995). Detecting Earnings Management. The Accounting Review, 70(2), 193-225.

Denis, D. J., Denis, D. K., \& Sarin, A. (1997). Agency Problems, Equity Ownership , and Corporate Diversification. The Journal of Finance, LII(1), 135-160.

Dewally, M., \& Shao, Y. (2012). Financial derivatives, opacity, and crash risk: Evidence from large US banks. Journal of Financial Stability, 1-13. doi:10.1016/j.jfs.2012.11.001

Diamond, D. W. (1984). Financial Intermediation and Delegated Monitoring. The Review of Economic Studies, 51(3), 393-414.

Doukas, J. a., Kim, C. (Francis), \& Pantzalis, C. (2010). Arbitrage Risk and Stock Mispricing. Journal of Financial and Quantitative Analysis, 45(04), 907934. doi:10.1017/S0022109010000293

Durnev, A., \& Guriev, S. (2011). Expropriation Risk, Corporate Transparency, and Growth. SSRN Electronic Journal (Vol. 1320966, pp. 0-52). Retrieved from http://dx.doi.org/10.2139/ssrn.1320966

Durnev, A., Morck, R., \& Yeung, B. (2000). Do Stock Prices Guide the Allocation of Capital? Working Paper, University of Michigan Business School., (June).

Durnev, A., Morck, R., \& Yeung, B. (2004). Value-Enhancing Capital Budgeting and Firm-specific Stock Return Variation. The Journal of Finance, 59(1), $65-105$.

Durnev, A., Morck, R., Yeung, B., \& Zarowin, P. (2003). Does Greater FirmSpecific Return Variation Mean More or Less Informed Stock Pricing? Journal of Accounting Research, 41(5), 797-836. doi:10.1046/j.1475679X.2003.00124.X

Easley, D., \& Hara, M. O. (2004). Information and the Cost of Capital. The Journal of Finance, LIX(4), 1553-1583.

Edmans, A. (2009). Blockholder Trading, Market Efficiency, and Managerial Myopia. The Journal of Finance, LXIV(6), 2481-2513. 
Elton, E. J., Gruber, M. J., Brown, S. J., \& Goetzmann, W. N. (2009). Modern portfolio theory and investment analysis. John Wiley \& Sons.

Fama, E. F. (1965a). Random Walks in Stock Market Prices. Financial Analysts Journal, 21(5), 55-59 CR - Copyright \&\#169; 1965 CFA Institute. doi:10.2307/4469865

Fama, E. F. (1965b). The Behavior of Stock-Market Prices. The Journal of Business, 38(1), 34-105.

Fama, E. F. (1970). Efficient Capital Markets: A Review Of Theory And Empirical Work. The Journal of Finance, 25(2), 383-417. doi:10.1111/j.15406261.1970.tb00518.x

Fama, E. F. (1976). Efficient Capital Markets: Reply. The Journal of Finance, 31(1), 143-145 CR - Copyright \&\#169; 1976 American Financ. doi: $10.2307 / 2326404$

Fama, E. F., \& French, K. R. (1992). The Cross-Section of Expected Stock Returns. The Journal of Finance, 47(2), 427-465.

Fama, E. F., \& French, K. R. (1993). Common risk factors in the returns on stocks and bonds. Journal of Financial Economics, 33(1), 3-56. doi:http://dx.doi.org/10.1016/0304-405X(93)90023-5

Fama, E. F., \& French, K. R. (2004). The Capital Asset Pricing Model: Theory and Evidence. The Journal of Economic Perspectives, 18(3), 25-46. doi:doi:10.1257/0895330042162430

Fan, J. P. ., \& Wong, T. . (2002). Corporate ownership structure and the informativeness of accounting earnings in East Asia. Journal of Accounting and Economics, 33(3), 401-425. doi:10.1016/S0165-4101(02)00047-2

Fernandes, N., \& Ferreira, M. a. (2007). Insider Trading Laws and Stock Price Informativeness. Review of Financial Studies, 22(5), 1845-1887. doi:10.1093/rfs/hhn066

Ferreira, M. A., \& Laux, P. A. (2007). Corporate Governance, Idiosyncratic Risk , and Information Flow. The Journal of Finance, LXII(2).

Fields, T. D., Lys, T. Z., \& Vincent, L. (2001). Empirical research on accounting choice. Journal of Accounting and Economics, 31(1-3), 255-307. doi:http://dx.doi.org/10.1016/S0165-4101(01)00028-3

Foster, G., Olsen, C., \& Shevin, T. (1984). Earnings Releases, Anomalies, and the Behavior of Security Returns. The Accounting Review, LIX(4), 574-603.

Francis, J. C. (1991). Investments: Analysis and Management. McGraw-Hill. 
Francis, J., LaFond, R., Olsson, P., \& Schipper, K. (2005). The market pricing of accruals quality. Journal of Accounting and Economics, 39(2), 295-327. doi:http://dx.doi.org/10.1016/j.jacceco.2004.06.003

Francis, J., Lafond, R., Olsson, P., \& Schipper, K. (2007). Information Uncertainty and Post-Earnings-Announcement-Drift. Journal of Business Finance \& Accounting, 34(3-4), 403-433. doi:10.1111/j.14685957.2007.02030.x

Frankfurter, G. M., \& McGoun, E. G. (2001). Anomalies in finance: What are they and what are they good for? International Review of Financial Analysis, $\quad 10(4), \quad 407-429 . \quad$ doi:http://dx.doi.org/10.1016/S10575219(01)00061-8

Fu, F. (2009). Idiosyncratic risk and the cross-section of expected stock returns. Journal of Financial Economics, 91(1), 24-37. doi:http://dx.doi.org/10.1016/j.jfineco.2008.02.003

Gigler, F., Hemmer, T., \& Dye, R. A. (1998). On the Frequency, Quality, and Informational Role of Mandatory Financial Reports. Journal of Accounting Research, 36(1998), 117-147. Retrieved from http://search.ebscohost.com/login.aspx?direct=true\&db=bth\&AN=172571 84\&lang=pt-br\&site=ehost-live

Goldsmith, R. W. (1955). Financial Structure and Economic Growth in Advanced Countries: An Experiment in Comparative Financial Morphology. In Capital Formation and Economic Growth (pp. 111-168). Princeton University Press. Retrieved from http://www.nber.org/chapters/c1304

Greenwood, J., \& Smith, B. D. (1997). Financial markets in development, and the development of financial markets. Journal of Economic Dynamics and Control, 21(1), 145-181. doi:10.1016/0165-1889(95)00928-0

Greenwood, R. (2008). Excess Comovement of Stock Returns: Evidence from Cross-Sectional Variation in Nikkei 225 Weights. Review of Financial Studies, 21(3), 1153-1186. doi:10.1093/rfs/hhm052

Grossman, S. (1976). On the efficiency of competitive stock markets where trades have diverse information. Journal of Finance, 31(2), 573-585. Retrieved from http://search.ebscohost.com/login.aspx?direct=true\&db=buh\&AN=465358 9\&lang=pt-br\&site=ehost-live

Grossman, S. J., \& Stiglitz, J. E. (1980). On the Impossibility of Informationally Efficient Markets. American Economic Review, 70(3), 393-408. Retrieved from http://ideas.repec.org/a/aea/aecrev/v70y1980i3p393-408.html

Gujarati, D. M. (2006). Econometria Básica. (Campus/Elsevier, Ed.) (quarta edi.). Rio de Janeiro. 
Gul, F. a., Cheng, L. T. W., \& Leung, T. Y. (2011). Perks and the informativeness of stock prices in the Chinese market. Journal of Corporate Finance, 17(5), 1410-1429. doi:10.1016/j.jcorpfin.2011.07.005

Gul, F. a., Kim, J.-B., \& Qiu, A. a. (2010). Ownership concentration, foreign shareholding, audit quality, and stock price synchronicity: Evidence from China. Journal of Financial Economics, 95(3), 425-442. doi:10.1016/j.jineco.2009.11.005

Gul, F. A., Srinidhi, B., \& Ng, A. C. (2011). Does board gender diversity improve the informativeness of stock prices? Journal of Accounting and Economics, 51(3), 314-338. doi:10.1016/j.jacceco.2011.01.005

Guo, H., \& Savickas, R. (2008). Average Idiosyncratic Volatility in G7 Countries. Review of Financial Studies, 21(3), 1259-1296. doi:10.1093/rfs/hhn043

Gutiérrez, L. H., \& Pombo, C. (2009). Corporate ownership and control contestability in emerging markets: The case of Colombia. Journal of Economics and Business, 61(2), 112-139. doi:10.1016/j.jeconbus.2008.01.002

Haggard, K. S., Martin, X., \& Pereira, R. (2008). Does Voluntary Disclosure Improve Stock Price Informativeness. Financial Management, 747-768.

Han, L., Lin, Z., \& Wei, S. X. (2010). Noise or Information : When Stock Price Synchronicity Meets Accounting Restatements. In Asian Finance (Ed.), European Financial Management Symposium 2010 (Vol. 1, pp. 1-46).

Hasan, I., Song, L., \& Wachtel, P. (2014). Institutional development and stock price synchronicity: Evidence from China. Journal of Comparative Economics, 42(1), 92-108. doi:10.1016/j.jce.2013.07.006

Haw, I.-M., Hu, B., Lee, J., \& Wu, W. (2012). Investor protection and price informativeness about future earnings: international evidence. Review of Accounting Studies, 17(2), 389-419 LA - English. doi:10.1007/s11142012-9181-z

He, W. (2011). Governance Transparency and Capital Allocation: A Note. Abacus, 47(1), 109-118. doi:10.1111/j.1467-6281.2011.00333.x

Healy, P. M., \& Wahlen, J. M. (1999). A Review of the Earnings Management Literature and Its Implications for Standard Setting. Accounting Horizons, 13(4), 365-383. Retrieved from http://search.ebscohost.com/login.aspx?direct=true\&db=buh\&AN=281129 7\&lang=pt-br\&site=ehost-live

Heflin, F., \& Shaw, K. W. (2000). Blockholder Ownership and Market Liquidity. Journal of Financial and Quantitative Analysis, 35(04), 621-633. doi:10.2307/2676258 
Hou, K., Dijk, M. A. Van, Zhang, Y., \& van Dijk, M. A. (2012). The implied cost of capital: A new approach. Journal of Accounting and Economics, 53(3), 504-526. doi:10.1016/j.jacceco.2011.12.001

Hou, K., Xiong, W., \& Peng, L. (2006). R2 and Price Inefficiency. Fisher College of Business Working Paper Series, nov.

Hsin, C., \& Tseng, P.-W. (2012). Stock price synchronicities and speculative trading in emerging markets. Journal of Multinational Financial Management, 22(3), 82-109. doi:10.1016/j.mulfin.2012.03.001

Hutton, A. P., Marcus, A. J., \& Tehranian, H. (2009). Opaque financial reports, R2, and crash risk. Journal of Financial Economics, 94, 67-86.

Instrução Normativa 358/02. (2002). Comissão de Valores Mobiliários. Brasil.

Irvine, P. J., \& Pontiff, J. (2007). Idiosyncratic Return Volatility, Cash Flows, and Product Market Competition. Review of Financial Studies, 22(3), 11491177. doi:10.1093/rfs/hhn039

Jegadeesh, N., \& Livnat, J. (2006). Post-Earnings-Announcement Drift: The Role of Revenue Surprises. Financial Analysts Journal, 62(2), 22-34. doi:10.2469/faj.v62.n2.4081

Jensen, C., \& Meckling, H. (1976). Theory of the firm: managerial behavior, agency costs and ownership structure. Journal of Financial Economics, 3, 305-360.

Jensen, M. C. (1986). Agency Costs of Free Cash Flow, Corporate Finance, and Takeovers Agency Costs of Free Cash Flow, Corporate Finance, and Takeovers. American Economic Review, 76(2), 333.

Jiang, G. J., Xu, D., \& Yao, T. (2009). The Information Content of Idiosyncratic Volatility. Journal of Financial and Quantitative Analysis, 44(01), 1. doi:10.1017/S0022109009090073

Jin, L., \& Myers, S. (2006). R2 around the world: New theory and new tests. Journal of Financial Economics, 79(2), 257-292. doi:10.1016/j.jineco.2004.11.003

Jones, C. P., \& Litzenberger, R. H. (1970). Quarterly Earnings Reports and Intermediate Stock Price Trends. Journal of Finance, 25(1), 143-148. Retrieved from http://search.ebscohost.com/login.aspx?direct=true\&db=buh\&AN=465532 7\&lang=pt-br\&site=ehost-live

Jones, J. J. (1991). Earnings management during import relief investigations. Journal of Accounting Research, 29(2), 193-228. 
Jung, K., \& Young, S. (2002). Ownership structure and earnings informativeness Evidence from Korea, 37, 301-325.

Kaniel, R., Ozoguz, A., \& Starks, L. (2012). The high volume return premium: Cross-country evidence. Journal of Financial Economics, 103(2), 255-279. doi:10.1016/j.jineco.2011.08.012

Kasznik, R. (1999). On the Association between Voluntary Disclosure and Earnings Management. Journal of Accounting Research, 37(1), 57-81. Retrieved from http://search.ebscohost.com/login.aspx?direct=true \&db=buh\&AN=220575 1\&lang=pt-br\&site=ehost-live

Kelly, B., T., Lustig, H. N., \& Van Nieuwerburgh, S. (2012). The Volatility Factor Structure. Fama-Miller Center for Research in Finance - The University of Chicago, Booth School of Business, Booth Rese. Retrieved from http://ssrn.com/abstract=2174541

Kelly, P. J. (2005). Information Efficiency and Firm-Specific Return Variation. EFA 2005 Moscow Meetings Paper. Retrieved from http://ssrn.com/abstract=676636 or http://dx.doi.org/10.2139/ssrn.676636

Khanna, T., \& Thomas, C. (2009). Synchronicity and firm interlocks in an emerging market. Journal of Financial Economics, 92, 182-204.

Kong, D., Xiao, T., \& Liu, S. (2011). Asymmetric information, firm investment and stock prices. China Finance Review International, 1(1), 6-33. doi:10.1108/20441391111092246

Kothari, S. P., Leone, A. J., \& Wasley, C. E. (2005). Performance matched discretionary accrual measures. Journal of Accounting and Economics, 39(1), 163-197. doi:10.1016/j.jacceco.2004.11.002

Kothari, S. P., \& Sloan, G. (1992). Implications for earnings response coefficients *. Journal of Accounting and Economics, 15, 143-171.

Kuhn, T. S. (1970). The Structure of Scientific Revolutions. (The University of Chicago, Ed.) (Second Edi., Vol. II).

Kumar, A., \& Lee, C. M. C. (2006). Retail Investor Sentiment and Return Comovements. The Journal of Finance, LXI(5), 2451-2486.

La Porta, R., Lopez-de-Silanes, F., Shleifer, A., \& Vishny, R. (2002). Investor Protection and Corporate Valuation. The Journal of Finance, 57(3), 11471170. doi:10.2307/2697775

Lakonishok, J., Shleifer, A., \& Vishny, R. W. (1994). Contrarian Investment, Extrapolation, and Risk. The Journal of Finance, 49(5), 1541-1578. doi:10.2307/2329262 
Lang, M., Lins, K. V., \& Maffett, M. (2011). Transparency, Liquidity, and Valuation: International Evidence on When Transparency Matters Most. Journal of Accounting Research, 50(3), 729-774. doi:10.1111/j.1475679X.2012.00442.x

Lang, M., \& Maffett, M. (2011). Transparency and liquidity uncertainty in crisis periods. Journal of Accounting and Economics, 52(2-3), 101-125. doi:http://dx.doi.org/10.1016/j.jacceco.2011.07.001

Lee, C. M. C. (2001). Market efficiency and accounting research: a discussion of "capital market research in accounting" by S.P. Kothari. Journal of Accounting and Economics, 31(1-3), 233-253. doi:http://dx.doi.org/10.1016/S0165-4101(01)00038-6

Lee, D. W., \& Liu, M. H. (2011). Does more information in stock price lead to greater or smaller idiosyncratic return volatility? Journal of Banking \& Finance, 35(6), 1563-1580. doi:10.1016/j.jbankfin.2010.11.002

LeRoy, S. F. (1976). Efficient Capital Markets: Comment. The Journal of Finance, 31(1), 139-141 CR - Copyright \&\#169; 1976 American Financ. doi:10.2307/2326403

LeRoy, S. F. (1989). Efficient Capital Markets and Martingales. Journal of Economic Literature, 27(4), 1583-1621 CR - Copyright \&\#169; 1989 American Econ. doi:10.2307/2727024

Levine, R. (1991). Stock Markets, Growth, and Tax Policy. The Journal of Finance, 46(4), 1445-1465. doi:10.2307/2328866

Levine, R. (1997). Stock Markets, Economic Development, and Capital Control Liberalization. Investment Company Institute Perspective, 3(5), 45-56.

Levine, R., \& Zervos, S. (1998). Stock Markets, Banks, and Economic Growth. The American Economic Review, 88(3), 537-558. doi:10.2307/116848

Lima, G. A. S. F. de. (2007). Utilização da teoria da divulgação para avaliação da relação do nível de disclosure com o custo da dívida das empresas brasileiras.

Disponível

em:

<http://www.teses.usp.br/teses/disponiveis/12/12136/tde-26112007165145/>. Acesso em: 2013-01-08.

Lin, C., Ma, Y., \& Xuan, Y. (2011). Ownership structure and financial constraints: Evidence from a structural estimation. Journal of Financial Economics, 102(2), 416-431. doi:10.1016/j.jfineco.2011.06.001

Lintner, J. (1956). Distribution of Incomes of Corporations Among Dividens, Retained Earnings, and Taxes. The American Economic Review, 46(2), 97-113. 
Lucena, P., \& Pinto, A. C. F., \& Lucena, Pierri; Pinto, A. C. F. (2005). Estudo de anomalias no mercado brasileiro de ações através de uma modificação no modelo de Fama e French. In XXIX ENANPAD. Brasília: ANPAD.

Mackay, C. (2001). Ilusões populares extraordinárias e a loucura das massas. (Ediouro, Ed.). Rio de Janeiro.

MacKinlay, A. C. (1997). Event Studies in Economics and Finance. Journal of Economic Literature, Vol. 35(1), 13-39.

Malacrida, M. J. C., \& Yamamoto, M. M. (2006). Governança corporativa: nível de evidenciação das informações e sua relação com a volatilidade das ações do Ibovespa. Caderno de Estudos, FIPECAFI, São Paulo.

Málaga, F. K., \& Securato, J. R. (2004). Aplicação do modelo de três fatores de Fama e French no mercado acionário brasileiro: um estudo empírico do período 1995-2003. In XVIII Encontro da ANPAD (Ed.), (pp. 1-16). Enanpad.

Markowitz, H. (1952). Portofolio Selection. The Journal of Finance, 7(1), 77-91. doi:10.1111/j.1540-6261.1952.tb01525.x

Markowitz, H. (1959). Portfolio Selection: Efficient Diversification of Investments. (I. Cowles Foundation Monograph No. 16. New York: John Wiley \& Sons, Ed.). New York: J. Wiley: Cowles Foundation M.

Martin, D. M. L., Cia, J. C., \& Kayo, E. K. (2010). Determinantes do risco idiossincrático no Brasil no período de 1996 a 2009. XXXIV Encontro Da Anpad, 1-12.

Martinez, A. L. (1995). Detectando Earnings Management no Brasil : Estimando os Accruals Discricionários. Revista de Contabilidade E Finanças, 19(46), 7-17.

Maug, E. (1998). Large Shareholders as Monitors: Is There a Trade-Off between Liquidity and Control? The Journal of Finance, 53(1), 65-98. doi:10.1111/0022-1082.35053

McWilliams, A., \& Siegel, D. (1997). Event Studies in Management Research: Theoretical and Empirical Issues. Journal, The Academy of Management, $40(3), 626-657$.

Mendenhall, R. R. (2004). Arbitrage Risk and Post- Earnings-Announcement Drift. Journal of Business, 77(4), 875-894.

Miller, M. H. (2000). The History of Finance: an Eyewitness Account. Journal of Applied Corporate Finance, 13(2), 8-14. doi:10.1111/j.17456622.2000.tb00050.x 
Morck, R. K. (2007). A history of corporate governance around the world: Family business groups to professional managers. University of Chicago Press.

Morck, R., Yeung, B., \& Yu, W. (2000). The information content of stock markets: why do emerging markets have synchronous stock price movements? Journal of Financial Economics, 58, 215-260.

Mossin, J. (1966). Equilibrium in a capital asset market. Econometrica: Journal of the Econometric Society, 768-783.

Mussa, A. (2012). A liquidez e os modelos de precificação de ativos: Um estudo empírico no mercado acionário brasileiro de 1995 A 2011. (Tese de doutorado, Faculdade de Economia, Administraçao e Contabilidade, Universidade de São Paulo, São Paulo).

Myers, S. C., \& Majluf, N. S. (1984). Corporate Financing and Investment Decisions When Firms Have Information That Investors Do Not Have. Journal of Financial Economics, 13(December - 2), 287-211. doi:10.1016/0304-405X(84)90023-0

Peterson, D. R., \& Smedema, A. R. (2011). The return impact of realized and expected idiosyncratic volatility. Journal of Banking \& Finance, 35(10), 2547-2558. doi:http://dx.doi.org/10.1016/j.jbankfin.2011.02.015

Pindyck, R. S., \& Rotemberg, J. J. (1993). The Comovement of Stock Prices. The Quarterly Journal of Economics, 108(4), 1073-1104.

Piotroski, J. D., \& Roulstone, D. (2004). The Influence of Analysts, Institutional Investors and Insiders on the Incorporation of Market, Industry and FirmSpecific Information into Stock Prices. The Accounting Reviewhe Accounting Review, 79(4), 1119-1151.

Pontiff, J. (2006). Costly arbitrage and the myth of idiosyncratic risk. Journal of Accounting and Economics, 42(1-2), 35-52. doi:10.1016/j.jacceco.2006.04.002

Rajgopal, S., \& Venkatachalam, M. (2011). Financial reporting quality and idiosyncratic return volatility. Journal of Accounting and Economics, 51(12), 1-20. doi:http://dx.doi.org/10.1016/j.jacceco.2010.06.001

Reilly, F. K. F. K. R., \& Brown, K. C. (2003). Investment Analysis and Portfolio Management (with Thomson One-Business School Edition and Stock-Trak Coupon) (7th Ed.). South-Western Pub.

Riedl, E. J., \& Serafeim, G. (2011). Information Risk and Fair Values: An Examination of Equity Betas. Journal of Accounting Research, 49(4), 10831122. doi:10.1111/j.1475-679X.2011.00408.x 
Roberts, H. V. (1959). Stock-Market "Patterns" and Financial Analysis: Methodological Suggestions. The Journal of Finance, 14(1), 1-10. doi:10.1111/j.1540-6261.1959.tb00481.x

Roll, R. (1988). R2. The Journal of Finance, 43(3), 541-566.

Roll, R., \& Ross, S. A. (1980). An Empirical Investigation of the Arbitrage Pricing Theory. The Journal of Finance, 35(5), 1073-1103. doi:10.2307/2327087

Ross, S. A. (1976). The arbitrage theory of capital asset pricing. Journal of Economic Theory, 13(3), 341-360. doi:http://dx.doi.org/10.1016/00220531(76)90046-6

Roychowdhury, S., \& Watts, R. L. (2006). Asymmetric Timeliness of Earnings, Market-to-Book and Conservatism in Financial Reporting. SSRN Electronic Journal. doi:10.2139/ssrn.638001

Ryan, B., Scapens, R., \& M., T. (2002). Research Method and Methodology in Finance and Accounting. (Thomson, Ed.) (2nd ed.). London, UK.

Sadka, R. (2006). Momentum and post-earnings-announcement drift anomalies: The role of liquidity risk. Journal of Financial Economics, 80(2), 309-349. doi:http://dx.doi.org/10.1016/j.jfineco.2005.04.005

Samuelson, P. A. (1965). Proof That Properly Anticipated Prices Fluctuate Randomly. Industrial Management Review, 6(2), 41-49.

Schipper, K. (1989). COMMENTARY on Earnings Management. Accounting Horizons, 3(4), 91-102. Retrieved from http://search.ebscohost.com/login.aspx?direct=true\&db=buh\&AN=481607 3\&lang=pt-br\&site=ehost-live

Sharpe, W. F. (1964). Capital Asset Prices: A Theory of Market Equilibrium under Conditions of Risk. The Journal of Finance, 19(3), 425-442.

Shiller, R. J. (1981). Do Stock Prices Move Too Much to be Justified by Subsequent Changes in Dividends? American Economic Review, 71(3), $421 . \quad$ Retrieved from http://search.ebscohost.com/login.aspx?direct=true\&db=buh\&AN=450398 0\&lang=pt-br\&site=ehost-live

Shleifer, A. (2003). Inefficient markets: An introduction to behavioral finance. OUP Oxford.

Shleifer, A., \& Vishny, R. W. (1986). Large shareholders and corporate control. Journal of Political Economy, 94(3-jun), 461-488. doi:10.2307/1833044

Shleifer, A., \& Vishny, R. W. (1990). Equilibrium Short Horizons of Investors and Firms. The American Economic Review, 80(2), 148-153 CR - Copyright \&\#169; 1990 American Econom. doi:10.2307/2006560 
Shleifer, A., \& Vishny, R. W. (1997). The Limits of Arbitrage. The Journal of Finance, LII(1), 35-55.

Silveira, A. D. M. da, Lanzana, A. P., Barros, L. A. B. de C., \& Famá, R. (2004). Efeito dos acionistas controladores no valor das companhias abertas brasileiras. Revista de Administração de Empresas Da Universidade de São Paulo, 39, 362-372.

Sirqueira, A. B. De, Guimar, A. E., \& Toledo, F. M. B. de. (2007). Boas Práticas de Governança Corporativa e Otimização de Portfólio: Uma Análise Comparativa.

Sloan, R. G. (1996). Do Stock Prices Fully Reflect Information in Accruals and Cash Flows about Future Earnings? The Accounting Review, 71(3 - Jul), 289-315.

Spiegel, M., \& Wang, X. (2005). Cross-sectional variation in stock returns: Liquidity and idiosyncratic risk. . Yale ICF Working Paper No. 05-13; EFA 2005 Moscow Meetings Paper. Available at SSRN: http://ssrn.com/abstract=709781. Retrieved from http://papers.ssrn.com/sol3/Papers.cfm?abstract_id=709781

Stephen, A. R., Randolph, W. W., \& Jeffrey, F. J. (2002). Corporate finance. The McGrew Company Inc.

Stowe, J. D., \& Xing, X. (2011). R2: Does it Matter for Firm Valuation? The Financial Review, 46(2), 233-250. doi:10.1111/j.1540-6288.2011.00298.x

Taylor, N. (2008). Can idiosyncratic volatility help forecast stock market volatility? International Journal of Forecasting, 24(3), 462-479. doi:http://dx.doi.org/10.1016/j.ijforecast.2008.06.001

Tobin, J. (1987). Policies for prosperity: essays in a Keynesian mode. (P. M. (Peter M. Jackson, Ed.). Cambridge, Mass. : MIT Press.

Tversky, A., \& Kahneman, D. (1974). Judgment under Uncertainty: Heuristics and Biases. Science (New York, N.Y.), 185(4157), 1124-31. doi:10.1126/science.185.4157.1124

U.S. Securities and Exchange Commission. (2009). Toward Greater Transparency: Modernizing the Securities and Exchange Commission's Disclosure System.

Veldkamp, L., \& Wolfers, J. (2007). Aggregate shocks or aggregate information? Costly information and business cycle comovement. Journal of Monetary Economics, 54, 37-55. doi:10.1016/j.jmoneco.2007.06.001

Villalonga, B., \& Amit, R. (2006). How do family ownership, control and management affect firm value? Journal of Financial Economics, 80(2), 385-417. doi:10.1016/j.jineco.2004.12.005 
Working, H. (1958). A Theory of Anticipatory Prices. The American Economic Review, 48(2), 188-199 CR - Copyright \&\#169; 1958 American Econom. doi:10.2307/1816908

Wurgler, J. (2000). Financial markets and the allocation of capital. Journal of Financial Economics, 58(1-2), 187-214. doi:10.1016/S0304405X(00)00070-2

Wurgler, J., \& Zhuravskaya, E. (2002). Does Arbitrage Flatten Demand Curves for Stocks? The Journal of Business, 75(4), 583-608. doi:10.1086/341636

Xing, X., Anderson, R., \& Xinga, X. (2011). Stock price synchronicity and public firm-specific information. Journal of Financial Markets, 14(2), 259-276. doi:10.1016/j.finmar.2010.10.001

Zhang, C. (2010). A Reexamination of the Causes of Time-Varying Stock Return Volatilities. Journal of Financial and Quantitative Analysis, 45(03), 663684. Retrieved from http://ideas.repec.org/a/cup/jinqa/v45y2010i03p663684_00.html

Zhang, X. F. (2006). Information Uncertainty and Stock Returns. The Journal of Finance, 61(1), 105-137.

Zhu, P., Jog, V., \& Otchere, I. (2014). Idiosyncratic volatility and mergers and acquisitions in emerging markets. Emerging Markets Review, 19, 18-48. doi:10.1016/j.ememar.2014.04.001 
APÊNDICE 1: Amostras das empresas observadas por ano - 2002 a 2012

Tabela 20: Amostras das empresas observadas por ano - 2002 a 2012

\begin{tabular}{|c|c|c|c|c|c|c|c|c|c|c|c|c|}
\hline Empresas & $\begin{array}{l}\text { Ocorrências } \\
\text { na amostra }\end{array}$ & 2002 & 2003 & 2004 & 2005 & 2006 & 2007 & 2008 & 2009 & 2010 & 2011 & 2012 \\
\hline Abc Brasil & 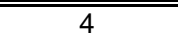 & & & & & & & & $\bar{x}$ & $\bar{X}$ & $\bar{X}$ & $\bar{x}$ \\
\hline Abyara & 1 & & & & & & & $\mathrm{x}$ & & & & \\
\hline Aco Altona & 2 & & & & & & & & & $x$ & $x$ & \\
\hline Acos Vill & 5 & & & $x$ & $x$ & $x$ & $x$ & $x$ & & & & \\
\hline AES Elpa & 4 & & & & & & $x$ & & & $x$ & $x$ & $x$ \\
\hline AES Tiete & 6 & & & & & $x$ & $x$ & $\mathrm{x}$ & $x$ & $x$ & $\mathrm{x}$ & \\
\hline Alfa Financ & 4 & & & & & & & $x$ & $x$ & $x$ & $x$ & \\
\hline Alfa Invest & 1 & & & & & & & $\mathrm{x}$ & & & & \\
\hline Aliansce & 1 & & & & & & & & & & & $\mathrm{x}$ \\
\hline All Amer Lat & 4 & & & & $x$ & & $x$ & $x$ & & & & $x$ \\
\hline Alpargatas & 9 & & $x$ & $x$ & $\mathrm{x}$ & $x$ & $x$ & & $x$ & $x$ & $\mathrm{x}$ & $\mathrm{x}$ \\
\hline Am Inox BR & 4 & $\mathrm{X}$ & $x$ & $x$ & $\mathrm{x}$ & & & & & & & \\
\hline Amazonia & 2 & & & $x$ & & & & & & & $x$ & \\
\hline Ambev S/A & 9 & & $\mathrm{X}$ & & $\mathrm{X}$ & $\mathrm{X}$ & $\mathrm{X}$ & $\mathrm{x}$ & $\mathrm{X}$ & $x$ & $\mathrm{x}$ & $\mathrm{X}$ \\
\hline Amil & 3 & & & & & & & & $x$ & $\mathrm{x}$ & $\mathrm{x}$ & \\
\hline Ampla Energ & 5 & & & $X$ & $x$ & $X$ & & $x$ & & $x$ & & \\
\hline Anhanguera & 1 & & & & & & & & & & & $\mathrm{x}$ \\
\hline Aracruz & 6 & $\mathrm{x}$ & $x$ & $x$ & $\mathrm{x}$ & $x$ & $x$ & & & & & \\
\hline Arcelor BR & 2 & $\mathrm{X}$ & & & $\mathrm{x}$ & & & & & & & \\
\hline Arteris & 6 & & & & & & $X$ & $\mathrm{X}$ & $X$ & $\mathrm{X}$ & $\mathrm{x}$ & $\mathrm{X}$ \\
\hline B2W Digital & 4 & & & & & & & & $x$ & $x$ & $\mathrm{x}$ & $x$ \\
\hline Banese & 3 & & & & $\mathrm{x}$ & & & $\mathrm{X}$ & $x$ & & & \\
\hline Banespa & 2 & & & $x$ & $\mathrm{X}$ & & & & & & & \\
\hline Banestes & 2 & & & & & & & $\mathrm{x}$ & & $\mathrm{x}$ & & \\
\hline Banrisul & 4 & & & & & & & & $x$ & $\mathrm{x}$ & $\mathrm{x}$ & $\mathrm{x}$ \\
\hline Bardella & 2 & $\mathrm{X}$ & & $X$ & & & & & & & & \\
\hline Bematech & 2 & & & & & & & & $x$ & $x$ & & \\
\hline $\mathrm{BHG}$ & 1 & & & & & & & & & & & $x$ \\
\hline Bicbanco & 2 & & & & & & & & & $\mathrm{X}$ & $x$ & \\
\hline BmfBovespa & 3 & & & & & & & & & $X$ & $X$ & $\mathrm{X}$ \\
\hline Bombril & 5 & $x$ & & $\mathrm{X}$ & & $\mathrm{X}$ & $x$ & $x$ & & & & \\
\hline BR Brokers & 3 & & & & & & & & & $\mathrm{X}$ & $\mathrm{x}$ & $\mathrm{x}$ \\
\hline BR Malls Par & 4 & & & & & & & & $x$ & $x$ & $x$ & $x$ \\
\hline BR Propert & 1 & & & & & & & & & & & $x$ \\
\hline Bradesco & 11 & $x$ & $x$ & $x$ & $\mathrm{x}$ & $x$ & $\mathrm{X}$ & $\mathrm{x}$ & $x$ & $\mathrm{X}$ & $\mathrm{x}$ & $x$ \\
\hline Bradespar & 11 & $\mathrm{X}$ & $x$ & $x$ & $\mathrm{X}$ & $x$ & $x$ & $\mathrm{x}$ & $x$ & $\mathrm{X}$ & $\mathrm{x}$ & $x$ \\
\hline Brasil & 9 & & $x$ & $x$ & $x$ & & $x$ & $x$ & $x$ & $x$ & $X$ & $x$ \\
\hline Brasil T Par & 5 & $x$ & $x$ & & $\mathrm{X}$ & $x$ & $x$ & & & & & \\
\hline Brasilagro & 2 & & & & & & & & & $x$ & $x$ & \\
\hline Braskem & 10 & $x$ & $x$ & $X$ & $x$ & $x$ & $x$ & $x$ & $X$ & & $x$ & $x$ \\
\hline Brasmotor & 4 & & & & & & & $x$ & & $x$ & $x$ & $x$ \\
\hline BRF SA & 7 & $\mathrm{X}$ & $\mathrm{x}$ & $x$ & & & & $\mathrm{x}$ & $x$ & $\mathrm{X}$ & & $x$ \\
\hline Brookfield & 4 & & & & & & & $x$ & $X$ & $\mathrm{X}$ & $X$ & \\
\hline Caemi & 3 & $x$ & $x$ & $x$ & & & & & & & & \\
\hline CC Des Imob & 2 & & & & & & & & $x$ & $x$ & & \\
\hline CCR SA & 9 & & & $x$ & $x$ & $x$ & $x$ & $x$ & $x$ & $x$ & $x$ & $x$ \\
\hline Celesc & 8 & $x$ & & $x$ & $x$ & $x$ & $x$ & $x$ & & & $x$ & $x$ \\
\hline Celpe & 3 & & & $x$ & $x$ & $x$ & & & & & & \\
\hline Cemar & 4 & & & & & & $\mathrm{X}$ & $\mathrm{X}$ & $X$ & & & $x$ \\
\hline Cemig & 10 & $x$ & $x$ & $x$ & $x$ & $x$ & $x$ & $x$ & $x$ & $x$ & $x$ & \\
\hline Cesp & 5 & & $\mathrm{X}$ & $X$ & $\mathrm{X}$ & & & & $X$ & $\mathrm{X}$ & & \\
\hline Cetip & 2 & & & & & & & & & & $x$ & $x$ \\
\hline Cia Hering & 4 & & & & & & & $x$ & & $x$ & $x$ & $x$ \\
\hline Cielo & 2 & & & & & & & & & & $x$ & $x$ \\
\hline Cobrasma & 2 & & & & & & & $x$ & & & $x$ & \\
\hline Coelce & 8 & $x$ & $x$ & & $x$ & & $\mathrm{X}$ & $x$ & $X$ & $x$ & $X$ & \\
\hline Comgas & 9 & $x$ & $x$ & $x$ & $x$ & $x$ & $x$ & $x$ & $x$ & $x$ & & \\
\hline Confab & 8 & & $x$ & $x$ & $x$ & $x$ & $x$ & $x$ & $x$ & $x$ & & \\
\hline Contax & 5 & & & & & & $x$ & & $x$ & $x$ & $x$ & $x$ \\
\hline Copasa & 3 & & & & & & & & $x$ & & $x$ & $x$ \\
\hline Copel & 10 & $x$ & $x$ & $x$ & $x$ & $x$ & $x$ & $x$ & $x$ & $x$ & $x$ & \\
\hline Copesul & 4 & $\mathrm{X}$ & $x$ & $x$ & $x$ & & & & & & & \\
\hline Cosan & 3 & & & & & & & & & $x$ & $x$ & $x$ \\
\hline Cosan Ltd & 3 & & & & & & & & & $x$ & $x$ & $x$ \\
\hline Cosipa & 1 & $x$ & & & & & & & & & & \\
\hline Coteminas & 10 & $x$ & $x$ & $x$ & $x$ & $x$ & $x$ & & $X$ & $x$ & $X$ & $x$ \\
\hline
\end{tabular}


Tabela 20 (continuação)

\begin{tabular}{|c|c|c|c|c|c|c|c|c|c|c|c|c|}
\hline Empresas & $\begin{array}{l}\text { Ocorrências } \\
\text { na amostra }\end{array}$ & 2002 & 2003 & 2004 & 2005 & 2006 & 2007 & 2008 & 2009 & 2010 & 2011 & 2012 \\
\hline "CPFL Energia & 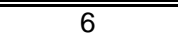 & & & & $\bar{x}$ & & $\bar{X}$ & & $\bar{X}$ & $\bar{X}$ & $\bar{X}$ & $\bar{x}$ \\
\hline $\mathrm{Cr} 2$ & 2 & & & & & & & & & & $x$ & $x$ \\
\hline Cremer & 4 & & & & & & & & $x$ & $x$ & $x$ & $x$ \\
\hline Crt Celular & 3 & $x$ & $x$ & $x$ & & & & & & & & \\
\hline Csu Cardsyst & 4 & & & & & & & $x$ & & $x$ & $x$ & $x$ \\
\hline Cyre Com-Ccp & 2 & & & & & & & & $\mathrm{X}$ & & & $\mathrm{X}$ \\
\hline Cyrela Realt & 6 & & & & & & $x$ & $x$ & $x$ & $x$ & $x$ & $x$ \\
\hline Dasa & 7 & & & & $x$ & & $x$ & $x$ & $x$ & $x$ & $x$ & $x$ \\
\hline Daycoval & 2 & & & & & & & & & & $x$ & $x$ \\
\hline Dimed & 1 & & & & & & & & & & & $x$ \\
\hline Direcional & 1 & & & & & & & & & & & $x$ \\
\hline Doc Imbituba & 2 & & & & & & & $x$ & & & $x$ & \\
\hline Dufry Ag & 1 & & & & & & & & & & & $x$ \\
\hline Duratex & 3 & & & & & & & & & $x$ & $x$ & $x$ \\
\hline Duratex-Old & 5 & $x$ & $x$ & & $x$ & $x$ & $x$ & & & & & \\
\hline Ecorodovias & 1 & & & & & & & & & & & $x$ \\
\hline Eletrobras & 8 & & $\mathrm{x}$ & $x$ & $\mathrm{x}$ & $x$ & $x$ & $\mathrm{x}$ & & $\mathrm{X}$ & $\mathrm{x}$ & \\
\hline Eletropaulo & 9 & $\mathrm{X}$ & & $X$ & $\mathrm{X}$ & $\mathrm{x}$ & & $\mathrm{X}$ & $X$ & $\mathrm{X}$ & $\mathrm{x}$ & $\mathrm{x}$ \\
\hline Emae & 4 & & $x$ & $x$ & $x$ & & & $x$ & & & & \\
\hline Embraco & 2 & & $x$ & $x$ & & & & & & & & \\
\hline Embraer & 8 & $x$ & & & $\mathrm{x}$ & $\mathrm{x}$ & $x$ & $\mathrm{x}$ & $\mathrm{x}$ & $\mathrm{X}$ & $\mathrm{x}$ & \\
\hline Embratel Part & 4 & $x$ & $x$ & & $x$ & & & & & $x$ & & \\
\hline Energias BR & 5 & & & & & & $x$ & $x$ & $x$ & $x$ & $x$ & \\
\hline Energisa & 1 & & & & & & & & $x$ & & & \\
\hline Eneva & 4 & & & & & & & & $x$ & $x$ & $\mathrm{x}$ & $\mathrm{x}$ \\
\hline Equatorial & 2 & & & & & & & & & & $x$ & $x$ \\
\hline Estacio Part & 3 & & & & & & & & & $\mathrm{x}$ & $\mathrm{x}$ & $x$ \\
\hline Estrela & 1 & & & & & & & $x$ & & & & \\
\hline Eternit & 8 & $x$ & $x$ & $x$ & & $x$ & $x$ & & $x$ & $x$ & $x$ & \\
\hline Eucatex & 2 & & & & & & & & & & $x$ & $x$ \\
\hline Even & 3 & & & & & & & & & $\mathrm{X}$ & $\mathrm{x}$ & $x$ \\
\hline Eztec & 4 & & & & & & & & $x$ & $x$ & $x$ & $x$ \\
\hline F Cataguazes & 3 & $x$ & $x$ & & $x$ & & & & & & & \\
\hline Fer Heringer & 3 & & & & & & & & $x$ & $x$ & $x$ & \\
\hline Ferbasa & 8 & $\mathrm{X}$ & $\mathrm{X}$ & & $\mathrm{X}$ & & & $\mathrm{X}$ & $X$ & $\mathrm{X}$ & $\mathrm{x}$ & $x$ \\
\hline Fertibras & 1 & & & $x$ & & & & & & & & \\
\hline Fibria & 7 & $x$ & $x$ & & $x$ & $x$ & $x$ & & & & $x$ & $x$ \\
\hline Fleury & 2 & & & & & & & & & & $\mathrm{x}$ & $x$ \\
\hline Forja Taurus & 5 & & $\mathrm{X}$ & & $x$ & & & $\mathrm{x}$ & & & $\mathrm{x}$ & $\mathrm{X}$ \\
\hline Fras-Le & 3 & & & & & & & $x$ & $x$ & $x$ & & \\
\hline Gafisa & 3 & & & & & & & & $x$ & & $\mathrm{x}$ & $\mathrm{x}$ \\
\hline Generalshopp & 2 & & & & & & & & & $\mathrm{x}$ & $\mathrm{x}$ & \\
\hline Gerdau & 11 & $x$ & $x$ & $x$ & $x$ & $x$ & $x$ & $x$ & $x$ & $x$ & $x$ & $x$ \\
\hline Gerdau Met & 9 & & $\mathrm{x}$ & $\mathrm{x}$ & $\mathrm{x}$ & & $\mathrm{X}$ & $\mathrm{x}$ & $x$ & $\mathrm{X}$ & $\mathrm{x}$ & $x$ \\
\hline Gol & 7 & & & & $x$ & $x$ & $x$ & $x$ & $x$ & $x$ & & $x$ \\
\hline Gp Invest & 5 & & & & & & & $\mathrm{x}$ & $\mathrm{X}$ & $\mathrm{x}$ & $\mathrm{x}$ & $\mathrm{X}$ \\
\hline GPC Part & 2 & & & & & & & $\mathrm{x}$ & $x$ & & & \\
\hline Grendene & 8 & & & & $x$ & $x$ & $x$ & $x$ & $X$ & $x$ & $x$ & $x$ \\
\hline Guararapes & 6 & & & & & $x$ & $x$ & $x$ & $x$ & $\mathrm{x}$ & & $x$ \\
\hline Haga S/A & 3 & & & & & & & & & $x$ & $x$ & $x$ \\
\hline Helbor & 4 & & & & & & & & $x$ & $\mathrm{X}$ & $\mathrm{x}$ & $x$ \\
\hline Hercules & 1 & & & & & & & & & & & $x$ \\
\hline Hoteis Othon & 1 & & & & & & & & & & $x$ & \\
\hline Hrt Petroleo & 1 & & & & & & & & & & & $\mathrm{x}$ \\
\hline Hypermarcas & 3 & & & & & & & & & $x$ & $x$ & $x$ \\
\hline Ideiasnet & 6 & & & & $x$ & & $x$ & $x$ & & $x$ & $x$ & $x$ \\
\hline lenergia & 1 & & & & & & & $x$ & & & & \\
\hline IGB S/A & 2 & $\mathrm{X}$ & & & & & & & & & & $\mathrm{X}$ \\
\hline Iguatemi & 4 & & & & & & & & $x$ & $x$ & $x$ & $x$ \\
\hline Inds Romi & 6 & & $x$ & & $x$ & & & & $x$ & $x$ & $x$ & $x$ \\
\hline Indusval & 2 & & & & & & & & $x$ & $x$ & & \\
\hline Inepar & 4 & $x$ & & & & & & & $x$ & $x$ & $x$ & \\
\hline lochp-Maxion & 3 & & & & $x$ & $x$ & & & & $X$ & & \\
\hline Ipiranga Dis & 3 & & & $x$ & $\mathrm{x}$ & $x$ & & & & & & \\
\hline Ipiranga Pet & 4 & $x$ & $x$ & & $\mathrm{X}$ & $\mathrm{X}$ & & & & & & \\
\hline Ipiranga Ref & 3 & & $x$ & $\mathrm{X}$ & & $\mathrm{X}$ & & & & & & \\
\hline Itausa & 11 & $\mathrm{x}$ & $x$ & $x$ & $\mathrm{x}$ & $x$ & $\mathrm{X}$ & $\mathrm{x}$ & $x$ & $\mathrm{x}$ & $\mathrm{x}$ & $x$ \\
\hline
\end{tabular}


Tabela 20 (continuação)

\begin{tabular}{|c|c|c|c|c|c|c|c|c|c|c|c|c|}
\hline Empresas & $\begin{array}{l}\text { Ocorrências } \\
\text { na amostra }\end{array}$ & 2002 & 2003 & 2004 & 2005 & 2006 & 2007 & 2008 & 2009 & 2010 & 2011 & 2012 \\
\hline ItauUnibanco & 11 & $\bar{X}$ & $\bar{X}$ & $\bar{X}$ & $\bar{X}$ & $\bar{X}$ & $\bar{x}$ & $\bar{X}$ & $\bar{X}$ & $\bar{X}$ & $\bar{X}$ & $\bar{x}$ \\
\hline J B Duarte & 1 & & & & & & & $x$ & & & & \\
\hline JBS & 3 & & & & & & & & & $x$ & $\mathrm{x}$ & $x$ \\
\hline Jereissati & 2 & & & & & & & $\mathrm{x}$ & & & & $x$ \\
\hline JHSF Part & 4 & & & & & & & & $x$ & $x$ & $x$ & $x$ \\
\hline Joao Fortes & 4 & & & & & & $\mathrm{X}$ & $\mathrm{x}$ & & & $\mathrm{x}$ & $\mathrm{X}$ \\
\hline JSL & 1 & & & & & & & & & & & $x$ \\
\hline Kepler Weber & 1 & & & $x$ & & & & & & & & \\
\hline Klabin S/A & 10 & $x$ & & $x$ & $x$ & $x$ & $x$ & $x$ & $x$ & $x$ & $x$ & $x$ \\
\hline Kroton & 4 & & & & & & & & $x$ & $x$ & $\mathrm{x}$ & $x$ \\
\hline Le Lis Blanc & 3 & & & & & & & & & $\mathrm{X}$ & $\mathrm{x}$ & $x$ \\
\hline Light S/A & 8 & $x$ & & $x$ & $x$ & & $x$ & $x$ & & $x$ & $x$ & $x$ \\
\hline Localiza & 6 & & & & & & $x$ & $x$ & $x$ & $x$ & $x$ & $x$ \\
\hline Log-In & 4 & & & & & & & & $\mathrm{X}$ & $x$ & $\mathrm{x}$ & $x$ \\
\hline Lojas Americ & 10 & & $\mathrm{x}$ & $\mathrm{X}$ & $\mathrm{X}$ & $\mathrm{x}$ & $\mathrm{x}$ & $\mathrm{x}$ & $x$ & $x$ & $\mathrm{x}$ & $x$ \\
\hline Lojas Marisa & 4 & & & & & & & & $x$ & $x$ & $x$ & $x$ \\
\hline Lojas Renner & 6 & & & & & & $x$ & $\mathrm{x}$ & $\mathrm{x}$ & $x$ & $\mathrm{x}$ & $x$ \\
\hline Lopes Brasil & 5 & & & & & & & $\mathrm{X}$ & $x$ & $\mathrm{X}$ & $\mathrm{x}$ & $x$ \\
\hline Lupatech & 3 & & & & & & & $\mathrm{x}$ & & $x$ & $\mathrm{x}$ & \\
\hline M G Poliest & 3 & & & $x$ & & $x$ & & $x$ & & & & \\
\hline M,Diasbranco & 5 & & & & & & & $\mathrm{x}$ & $\mathrm{x}$ & $x$ & $\mathrm{x}$ & $x$ \\
\hline Magnesita & 3 & $x$ & $x$ & & & $x$ & & & & & & \\
\hline Magnesita SA & 3 & & & & & & & & & $x$ & $x$ & $x$ \\
\hline Mangels Indl & 6 & & & $\mathrm{X}$ & $\mathrm{x}$ & $\mathrm{x}$ & $x$ & & $x$ & & $\mathrm{x}$ & \\
\hline Marcopolo & 7 & $x$ & & & & $\mathrm{x}$ & $\mathrm{x}$ & $\mathrm{x}$ & & $x$ & $\mathrm{x}$ & $x$ \\
\hline Marfrig & 2 & & & & & & & & $x$ & $x$ & & \\
\hline Marisol & 2 & & & & & & & & $x$ & $x$ & & \\
\hline Medial Saude & 1 & & & & & & & $\mathrm{x}$ & & & & \\
\hline Merc Brasil & 2 & & & & & & & & & & $\mathrm{x}$ & $x$ \\
\hline Merc Invest & 2 & & & & & & & $x$ & $x$ & & & \\
\hline Metal Iguacu & 1 & & & & & & & & & & & $x$ \\
\hline Metal Leve & 4 & & & $x$ & & $x$ & $x$ & $x$ & & & & \\
\hline Metalfrio & 2 & & & & & & & & & $x$ & $x$ & \\
\hline Millennium & 3 & & & & & & & & $\mathrm{x}$ & $x$ & $\mathrm{x}$ & \\
\hline Mills & 1 & & & & & & & & & & & $x$ \\
\hline Minerva & 4 & & & & & & & & $x$ & $x$ & $x$ & $x$ \\
\hline Minupar & 5 & $\mathrm{X}$ & & & & & & & $\mathrm{X}$ & $\mathrm{X}$ & $\mathrm{x}$ & $x$ \\
\hline MMX Miner & 4 & & & & & & & & $x$ & $x$ & $\mathrm{x}$ & $x$ \\
\hline MRV & 3 & & & & & & & & $\mathrm{X}$ & $x$ & $\mathrm{X}$ & \\
\hline Multiplan & 4 & & & & & & & & $x$ & $x$ & $x$ & $x$ \\
\hline Multiplus & 1 & & & & & & & & & & & $x$ \\
\hline Mundial & 2 & & & & & $x$ & & & & $\mathrm{x}$ & & \\
\hline Natura & 6 & & & & $x$ & $x$ & & & $x$ & $x$ & $x$ & $x$ \\
\hline Net & 7 & $\mathrm{X}$ & & & $\mathrm{x}$ & $\mathrm{x}$ & $x$ & $\mathrm{x}$ & $\mathrm{X}$ & & $x$ & \\
\hline Nossa Caixa & 1 & & & & & & $x$ & & & & & \\
\hline Odontoprev & 4 & & & & & & & $\mathrm{x}$ & & $\mathrm{X}$ & $\mathrm{x}$ & $\mathrm{X}$ \\
\hline OGX Petroleo & 2 & & & & & & & & & $x$ & $x$ & \\
\hline $\mathrm{Oi}$ & 7 & $x$ & $x$ & & & $x$ & $x$ & $x$ & $x$ & & $x$ & \\
\hline OSX Brasil & 1 & & & & & & & & & & & $\mathrm{X}$ \\
\hline P,Acucar-Cbd & 11 & $x$ & $x$ & $x$ & $x$ & $x$ & $x$ & $x$ & $x$ & $x$ & $x$ & $x$ \\
\hline Panamericano & 2 & & & & & & & & $x$ & & & $x$ \\
\hline Parana & 2 & & & & & & & & & & $x$ & $x$ \\
\hline Paranapanema & 7 & $x$ & & $x$ & $x$ & $x$ & $x$ & $x$ & & $x$ & & \\
\hline PDG Realt & 3 & & & & & & & & $x$ & $x$ & $\mathrm{x}$ & \\
\hline Pet Manguinh & 1 & & & & & & & & & & $x$ & \\
\hline Petrobras & 10 & $x$ & $X$ & & $x$ & $x$ & $x$ & $x$ & $x$ & $x$ & $x$ & $x$ \\
\hline Petroq Uniao & 1 & & & & & & $x$ & & & & & \\
\hline Pettenati & 1 & & & & & & & & & & $x$ & \\
\hline Pine & 2 & & & & & & & & & & $x$ & $x$ \\
\hline Plascar Part & 1 & & & & & & & & & & $x$ & \\
\hline Politeno & 2 & $x$ & $x$ & & & & & & & & & \\
\hline Porto Seguro & 5 & & & & & & $x$ & $x$ & $x$ & & $x$ & $x$ \\
\hline Portobello & 2 & & & & & & & & $x$ & $x$ & & \\
\hline Positivo Inf & 3 & & & & & & & & & $x$ & $x$ & $x$ \\
\hline Pro Metalurg & 2 & & & & $x$ & & & & $X$ & & & \\
\hline Profarma & 3 & & & & & & & $\mathrm{X}$ & & $X$ & & $X$ \\
\hline Providencia & 2 & & & & & & & & $x$ & & & $x$ \\
\hline
\end{tabular}


Tabela 20 (continuação)

\begin{tabular}{|c|c|c|c|c|c|c|c|c|c|c|c|c|}
\hline Empresas & $\begin{array}{l}\text { Ocorrências } \\
\text { na amostra }\end{array}$ & 2002 & 2003 & 2004 & 2005 & 2006 & 2007 & 2008 & 2009 & 2010 & 2011 & 2012 \\
\hline Prumo & 2 & & & & & & & & $\bar{X}$ & & $\bar{X}$ & \\
\hline Quattor Petr & 3 & & $x$ & & $x$ & $x$ & & & & & & \\
\hline RaiaDrogasil & 3 & & & & & & & & $\mathrm{X}$ & $\mathrm{X}$ & & $\mathrm{X}$ \\
\hline Randon Part & 9 & $\mathrm{X}$ & $x$ & $x$ & $\mathrm{X}$ & $x$ & $\mathrm{x}$ & & $x$ & $x$ & $x$ & \\
\hline Rasip Agro & 4 & & & & & & & $x$ & $x$ & $x$ & $x$ & \\
\hline Recrusul & 2 & & & & & & & $\mathrm{X}$ & & & & $\mathrm{X}$ \\
\hline Redecard & 2 & & & & & & & & $\mathrm{X}$ & $x$ & & \\
\hline Renar & 3 & & & & & & & & $x$ & $x$ & $x$ & \\
\hline Ripasa & 3 & $\mathrm{X}$ & $x$ & $X$ & & & & & & & & \\
\hline Rodobensimob & 3 & & & & & & & & $\mathrm{X}$ & & $\mathrm{X}$ & $\mathrm{X}$ \\
\hline Rossi Resid & 6 & & & & & & $x$ & $\mathrm{X}$ & $\mathrm{X}$ & $x$ & $x$ & $\mathrm{X}$ \\
\hline Sabesp & 9 & $\mathrm{X}$ & $x$ & $X$ & $x$ & & $x$ & $\mathrm{X}$ & $x$ & $x$ & $x$ & \\
\hline Sadia S/A & 5 & & $\mathrm{X}$ & $\mathrm{X}$ & $\mathrm{X}$ & $\mathrm{X}$ & $\mathrm{X}$ & & & & & \\
\hline Sanepar & 7 & & $x$ & $X$ & $x$ & $x$ & & & $x$ & $x$ & & $\mathrm{X}$ \\
\hline Sansuy & 2 & & & & & & & & $x$ & & & $\mathrm{X}$ \\
\hline Santander BR & 3 & & & & & & & $\mathrm{X}$ & & $x$ & $\mathrm{X}$ & \\
\hline Santanense & 3 & & & & & & & & $\mathrm{x}$ & $x$ & $\mathrm{x}$ & \\
\hline Santistextil & 1 & $\mathrm{X}$ & & & & & & & & & & \\
\hline Santos Brp & 3 & & & & & & & & & $x$ & $x$ & $\mathrm{X}$ \\
\hline Sao Carlos & 4 & & & & & & $\mathrm{X}$ & & $\mathrm{X}$ & & $\mathrm{X}$ & $\mathrm{X}$ \\
\hline Sao Martinho & 4 & & & & & & & & $x$ & $x$ & $x$ & $x$ \\
\hline Saraiva Livr & 7 & & & & $x$ & & $x$ & $\mathrm{X}$ & $x$ & $x$ & $x$ & $\mathrm{X}$ \\
\hline Savarg & 1 & & & & $\mathrm{X}$ & & & & & & & \\
\hline Schulz & 1 & & & & & & & $\mathrm{x}$ & & & & \\
\hline Seara Alim & 1 & $\mathrm{X}$ & & & & & & & & & & \\
\hline Sid Nacional & 10 & $\mathrm{X}$ & $X$ & $x$ & $x$ & & $\mathrm{x}$ & $x$ & $\mathrm{x}$ & $x$ & $\mathrm{X}$ & $\mathrm{X}$ \\
\hline Sid Tubarao & 1 & $\mathrm{X}$ & & & & & & & & & & \\
\hline SLC Agricola & 4 & & & & & & & & $\mathrm{x}$ & $x$ & $x$ & $\mathrm{X}$ \\
\hline Sofisa & 3 & & & & & & & & $\mathrm{x}$ & $x$ & $x$ & \\
\hline Souza Cruz & 9 & $\mathrm{X}$ & $\mathrm{X}$ & & $\mathrm{X}$ & $\mathrm{X}$ & $\mathrm{X}$ & $\mathrm{x}$ & & $\mathrm{X}$ & $\mathrm{X}$ & $\mathrm{X}$ \\
\hline Springer & 1 & & & & & & & & & & & $\mathrm{X}$ \\
\hline Springs & 4 & & & & & & & & $\mathrm{x}$ & $x$ & $x$ & $\mathrm{X}$ \\
\hline Sudameris & 1 & $\mathrm{X}$ & & & & & & & & & & \\
\hline Sul America & 3 & & & & & & & & $x$ & $x$ & & $x$ \\
\hline Sultepa & 3 & & & & & & $x$ & $\mathrm{X}$ & & $x$ & & \\
\hline Suzano Papel & 10 & $\mathrm{X}$ & $\mathrm{X}$ & $\mathrm{X}$ & $x$ & $x$ & $x$ & & $x$ & $\mathrm{X}$ & $\mathrm{X}$ & $\mathrm{X}$ \\
\hline Taesa & 1 & & & & & & & $\mathrm{X}$ & & & & \\
\hline Tam S/A & 5 & & & & $x$ & $x$ & $\mathrm{x}$ & $\mathrm{x}$ & $\mathrm{x}$ & & & \\
\hline Tecnisa & 4 & & & & & & & & $\mathrm{X}$ & $\mathrm{X}$ & $\mathrm{X}$ & $\mathrm{X}$ \\
\hline Tectoy & 4 & & & & & & & $\mathrm{X}$ & & $\mathrm{X}$ & $\mathrm{X}$ & $\mathrm{X}$ \\
\hline Tegma & 4 & & & & & & & & $x$ & $x$ & $x$ & $\mathrm{X}$ \\
\hline Tele Centroeste Cel & 2 & & $x$ & $\mathrm{X}$ & & & & & & & & \\
\hline Tele Leste Celular & 2 & $\mathrm{X}$ & & $\mathrm{X}$ & & & & & & & & \\
\hline Tele Nort Cl & 3 & $\mathrm{X}$ & & $\mathrm{X}$ & $\mathrm{X}$ & & & & & & & \\
\hline Tele Sudeste Celula & 3 & $\mathrm{X}$ & $x$ & $x$ & & & & & & & & \\
\hline Telebras & 2 & $\mathrm{X}$ & & & $\mathrm{X}$ & & & & & & & \\
\hline Telef Brasil & 11 & $\mathrm{X}$ & $\mathrm{X}$ & $\mathrm{X}$ & $\mathrm{X}$ & $\mathrm{X}$ & $\mathrm{X}$ & $\mathrm{x}$ & $\mathrm{X}$ & $\mathrm{X}$ & $\mathrm{X}$ & $\mathrm{X}$ \\
\hline Telefonica Data HId & 2 & $\mathrm{X}$ & $\mathrm{x}$ & & & & & & & & & \\
\hline Telemar & 7 & $\mathrm{X}$ & $x$ & $\mathrm{X}$ & $x$ & $\mathrm{x}$ & & $\mathrm{X}$ & $\mathrm{x}$ & & & \\
\hline Telemar N L & 6 & $\mathrm{X}$ & $\mathrm{X}$ & & $\mathrm{X}$ & $\mathrm{X}$ & & $\mathrm{X}$ & $\mathrm{X}$ & & & \\
\hline Telemig Part & 6 & $\mathrm{X}$ & $\mathrm{x}$ & $\mathrm{x}$ & $x$ & $\mathrm{x}$ & $\mathrm{x}$ & & & & & \\
\hline Tempo Part & 4 & & & & & & & & $x$ & $x$ & $\mathrm{x}$ & $\mathrm{X}$ \\
\hline Tex Renaux & 1 & & & & & & & & & $x$ & & \\
\hline Tim Part S/A & 11 & $\mathrm{X}$ & $x$ & $x$ & $x$ & $x$ & $x$ & $x$ & $x$ & $x$ & $x$ & $\mathrm{X}$ \\
\hline Tim Sul & 1 & $\mathrm{X}$ & & & & & & & & & & \\
\hline Totvs & 5 & & & & & & & $\mathrm{X}$ & $\mathrm{X}$ & $\mathrm{X}$ & $\mathrm{X}$ & $\mathrm{X}$ \\
\hline Tractebel & 8 & $\mathrm{X}$ & & & $\mathrm{X}$ & $\mathrm{X}$ & $\mathrm{X}$ & $\mathrm{x}$ & $\mathrm{X}$ & $\mathrm{X}$ & $\mathrm{X}$ & \\
\hline Tran Paulist & 9 & $\mathrm{X}$ & $x$ & & $x$ & $x$ & $x$ & $\mathrm{X}$ & $\mathrm{x}$ & $x$ & $X$ & \\
\hline Trisul & 4 & & & & & & & & $x$ & $x$ & $x$ & $x$ \\
\hline Triunfo Part & 3 & & & & & & & & & $X$ & $X$ & $\mathrm{X}$ \\
\hline Tupy & 1 & & & & & & & & & & $x$ & \\
\hline Ultrapar & 4 & & & $x$ & $x$ & & $x$ & & $x$ & & & \\
\hline Unibanco & 6 & $\mathrm{X}$ & $\mathrm{X}$ & $\mathrm{X}$ & $x$ & $X$ & $X$ & & & & & \\
\hline Unipar & 7 & $\mathrm{X}$ & & $X$ & $X$ & $\mathrm{X}$ & & $x$ & & & $\mathrm{X}$ & $\mathrm{X}$ \\
\hline Uol & 2 & & & & & & $x$ & $x$ & & & & \\
\hline Usiminas & 11 & $\mathrm{X}$ & $x$ & $x$ & $x$ & $x$ & $x$ & $x$ & $x$ & $x$ & $x$ & $\mathrm{X}$ \\
\hline V-Agro & 3 & & & & & & & $x$ & & $x$ & & $x$ \\
\hline
\end{tabular}


Tabela 20 (continuação)

\begin{tabular}{|c|c|c|c|c|c|c|c|c|c|c|c|c|}
\hline Empresas & $\begin{array}{l}\text { Ocorrências } \\
\text { na amostra }\end{array}$ & 2002 & 2003 & 2004 & 2005 & 2006 & 2007 & 2008 & 2009 & 2010 & 2011 & 2012 \\
\hline Vale & $\overline{111}$ & $\bar{X}$ & $\bar{X}$ & $\bar{X}$ & $\bar{x}$ & $\bar{x}$ & $\bar{X}$ & $\bar{X}$ & $\bar{X}$ & $\bar{X}$ & $\bar{x}$ & $\bar{X}$ \\
\hline Valefert & 7 & $\mathrm{X}$ & $x$ & $\mathrm{x}$ & $\mathrm{X}$ & & & $x$ & $\mathrm{x}$ & $\mathrm{X}$ & & \\
\hline Valid & 4 & & & & & & & & $\mathrm{x}$ & $x$ & $\mathrm{x}$ & $\mathrm{x}$ \\
\hline Viver & 3 & & & & & & & & & $x$ & $\mathrm{X}$ & $\mathrm{x}$ \\
\hline Vivo & 8 & $x$ & $x$ & $x$ & $x$ & $x$ & $x$ & $x$ & $x$ & & & \\
\hline Weg & 5 & $x$ & $x$ & & & & & & & $x$ & $x$ & $x$ \\
\hline Wetzel S/A & 1 & & & & $x$ & & & & & & & \\
\hline Whirlpool & 4 & & & & & & & $\mathrm{x}$ & $\mathrm{x}$ & $\mathrm{x}$ & & $\mathrm{x}$ \\
\hline Wilson Sons & 3 & & & & & & & & & $\mathrm{X}$ & $\mathrm{x}$ & $x$ \\
\hline WIm Ind Com & 1 & & & & $x$ & & & & & & & \\
\hline Yara Brasil & 1 & & $\mathrm{x}$ & & & & & & & & & \\
\hline
\end{tabular}




\section{APÊNDICE 2: Intervalo de confiança da liquidez em bolsa por quartil de participação acionária}

Tabela 21: Intervalo de confiança da liquidez em bolsa por quartil de participação acionária

\begin{tabular}{|c|c|c|c|c|c|c|}
\hline $\begin{array}{l}\text { Participação do maior } \\
\text { acionista }\end{array}$ & $\begin{array}{c}\text { Número de } \\
\text { Observações }\end{array}$ & $\begin{array}{l}\text { Liquidez em } \\
\text { bolsa (média) }\end{array}$ & $\begin{array}{l}\text { Desvio } \\
\text { Padrão }\end{array}$ & $\begin{array}{l}\text { Coeficiente de } \\
\text { variação }\end{array}$ & \multicolumn{2}{|c|}{$\begin{array}{c}\text { Intervalo de } \\
\text { Confiança (95\%) }\end{array}$} \\
\hline $0 \%$ a $20 \%$ & 250 & 0,753 & 1,367 & 1,815 & 0,583 & 0,924 \\
\hline$>20 \%$ a $32 \%$ & 303 & 0,686 & 1,081 & 1,576 & 0,564 & 0,809 \\
\hline$>32 \%$ a $52 \%$ & 300 & 0,880 & 2,018 & 2,293 & 0,651 & 1,109 \\
\hline$>52 \%$ a $98 \%$ & 288 & 0,347 & 0,632 & 1,819 & 0,274 & 0,421 \\
\hline $\begin{array}{l}\text { Participação dos três } \\
\text { maiores acionistas }\end{array}$ & $\begin{array}{c}\text { Número de } \\
\text { Observações }\end{array}$ & $\begin{array}{l}\text { Liquidez em } \\
\text { bolsa (média) }\end{array}$ & $\begin{array}{l}\text { Desvio } \\
\text { Padrão }\end{array}$ & $\begin{array}{l}\text { Coeficiente de } \\
\text { variação }\end{array}$ & \multicolumn{2}{|c|}{$\begin{array}{c}\text { Intervalo de } \\
\text { Confiança (95\%) }\end{array}$} \\
\hline $0 \%$ a $38 \%$ & 266 & 1,0230 & 1,839 & 1,798 & 0,801 & 1,245 \\
\hline$>38 \%$ a $52 \%$ & 275 & 1,0229 & 1,873 & 1,831 & 0,800 & 1,245 \\
\hline$>52 \%$ a $70 \%$ & 312 & 0,4404 & 0,722 & 1,639 & 0,360 & 0,521 \\
\hline$>70 \%$ a $99 \%$ & 288 & 0,2414 & 0,366 & 1,518 & 0,199 & 0,284 \\
\hline
\end{tabular}

As subamostras correspondem aos quartis de participação acionária 